UNIVERSIDADE DE SÃO PAULO

FACULDADE DE FILOSOFIA, LETRAS E CIÊNCIAS HUMANAS

DEPARTAMENTO DE LETRAS MODERNAS

PROGRAMA DE PÓS-GRADUAÇÃO EM

LÍNGUA ESPANHOLA E LITERATURAS ESPANHOLA E HISPANO-AMERICANA

ROBSON BATISTA DOS SANTOS HASMANN

\title{
O peso da História e seus personagens na dramaturgia de Rodolfo Usigli, Vicente Leñero e Sabina Berman
}

São Paulo

novembro de 2018 
UNIVERSIDADE DE SÃO PAULO

FACULDADE DE FILOSOFIA, LETRAS E CIÊNCIAS HUMANAS

DEPARTAMENTO DE LETRAS MODERNAS

PROGRAMA DE PÓS-GRADUAÇ̃̃O EM

LÍNGUA ESPANHOLA E LITERATURAS ESPANHOLA E HISPANO-AMERICANA

ROBSON BATISTA DOS SANTOS HASMANN

\title{
O peso da História e seus personagens na dramaturgia de Rodolfo Usigli, Vicente Leñero e Sabina Berman
}

\begin{abstract}
Tese apresentada ao programa de pós-graduação em Língua Espanhola e Literaturas Espanhola e Hispano-americana do Departamento de Letras Modernas da Faculdade de Filosofia, Letras e Ciências Humanas da Universidade de São Paulo, como exigência parcial para recebimento do título de Doutor em Letras.
\end{abstract}

Orientadora: Profa. Dra. Laura Janina Hosiasson

São Paulo

novembro de 2018 
Autorizo a reprodução e divulgação total ou parcial deste trabalho, por qualquer meio convencional ou eletrônico, para fins de estudo e pesquisa, desde que citada a fonte.

Catalogação na Publicação

Serviço de Biblioteca e Documentação

Faculdade de Filosofia, Letras e Ciências Humanas da Universidade de São Paulo

H322q

Hasmann, Robbson Batista dos Santos

O peso da história e seus personagens na

dramaturgia de Rodolfo Usigli, Vicente

Leñero e Sabina Berman / Robbson Batista dos Santos

Hasmann; orientadora Laura Janina Hosiasson. - São

Paulo, 2018.

$268 \mathrm{f}$.

Tese (Doutorado)- Faculdade de Filosofia, Letras e Ciências Humanas da Universidade de São Paulo.

Departamento de Letras Modernas. Área de concentração:

Língua Espanhola e Literaturas Espanhola e Hispano-

Americana.

1. Dramaturgia. 2. historiografia. 3. teatro. 4. identidade. 5. México. I. Hosiasson, Laura Janina, orient. II. Título. 


\section{FOLHA DE APROVAÇÃO}

Nome: HASMANN, Robson Batista dos Santos

Título:

Tese apresentada à Faculdade de Filosofia, Letras e Ciências Humanas da Universidade de São Paulo para obtenção do título de doutor em Letras.

Aprovado em:

Banca Examinadora

Profa.Dra. Laura Janina Hosiasson

Instituição: FFLCH-USP

Orientadora

Profa. Dra. Gênese Andrade da Silva

Instituição: FAAP

Julgamento:

Profa. Dra. Maria Sílvia Betti

Instituição: FFLCH-USP

Julgamento:

Prof. Dr. Gabriela Pellegrino Soares

Instituição: FFLCH-USP

Julgamento: 


\section{DEDICATÓRIA}

Para o Lucas, meu filho, que nasceu com esta tese e que me tem feito redescobrir a afetividade da linguagem e experimentar o mundo como novidade. 


\section{AGRADECIMENTOS}

Ao Instituto Federal de Educação, Ciência e Tecnologia de São Paulo, por haver concedido licença para auto-capacitação;

Ao Prof. Dr. Armando Partida Tayzan, da Universidad Autónoma de México (UNAM) cujos livros presenteados foram tão significativos quanto a atenção em trâmites de viagem;

À Sra. Julieta Rivas Palacio, do Centro de Investigaciones Teatrales Rodolfo Usigli (CITRU), pelas indicações de leitura e a concessão de materiais extras;

À escritora Sabina Berman, pela docilidade com que me concedeu uma entrevista;

À Bruna Dias, ex-aluna no IFSP - São João da Boa Vista, por facilitar o empréstimo na UNESP;

À Andressa Jove Godoy, também ex-aluna em São João da Boa Vista e hoje companheira de Letras e profissão, pela revisão da primeira versão;

Ao Prof. Dr. Pablo Gasparini, tão dedicado a resolver os problemas dos alunos e envolvimento ético pela permanência e aprimoramento do Programa;

Às professoras Gênese Andrade da Silva e Maria Sílvia Betti, cujas sugestões e leituras prévias foram ricas demais;

À Gabriele Franco, a Gabi, que tornou a pós-graduação menos solitária;

À Júnia Botelho, pela tradução do francês;

À minha esposa, Sandreli, suporte e companheira de tanta vida.

Agradecimento especial à Profa. Dra. LAURA JANINA HOSIASSON, por sempre acreditar no meu trabalho. 


\section{RESUMO}

HASMANN, Robson Batista dos Santos. O peso da História e suas personagens na dramaturgia de Rodolfo Usigli, Vicente Leñero e Sabina Berman. 2018. 268f. Tese (Doutorado) - Faculdade de Filosofia, Letras e Ciências Humanas, Universidade de São Paulo, São Paulo, 2018.

Esta tese investiga a formação do sistema dramatúrgico mexicano no século $\mathrm{XX}$ tendo como ponto de partida a relação entre literatura dramática e história. A proposta principal é identificar em que medida as estratégias de ficcionalização de eventos históricos contribuíram para as transformações textuais e cênicas de um período que abarca desde os anos pós-revolucionários até os umbrais da pós-modernidade. O estudo tenta contribuir para a história da dramaturgia mexicana considerando as pesquisas já realizadas por Partida Tayzan (2002a y 2002b), Adame (2004) e Alcántara Mejía (2010). Para isso, seleciona obras de Rodolfo Usigli, Vicente Leñero e Sabina Berman. Do primeiro interessam as concepções sobre teatro (mormente o conceito de "anti-história") e a postura nacionalista-crítica assumida em El gesticulador e na chamada trilogia das coroas. Assim, as obras dramáticas são confrontadas com os paratextos produzidos a propósito das encenações ou publicações. De Leñero, aproveita-se a maneira como são reescritos os documentos dos eventos representados, em Pueblo rechazado, Martirio de Morelos e La noche de Hernán Cortés. Finalmente, com Berman verifica-se que a inserção dos fatos históricos e elementos culturais ganha nova roupagem em Águila o sol, La grieta e Entre Villa y una mujer desnuda. O cotejo das estratégias nesses três casos permite constatar, primeiramente, que o apelo à história e à historiografia harmoniza o sistema de modo que a sucessão geracional se vê marcada pela aglutinação de recursos e concepções estéticas. Ao mesmo tempo, a reescrita da história altera-se no que diz respeito ao que pode ser considerado histórico. De Usigli a Berman, o passado enquanto local de revisitação, cede cada vez mais espaço ao presente e àquilo que permanece. Em termos sintéticos, podemos afirmar que a principal mudança temática foi a substituição de uma dramaturgia que buscava no passado as explicações do presente por outra em que os elementos pretéritos são abordados com desconfiança. Já sob a perspectiva estética, procedimentos como a inserção de personagens-narradores (historiadores, cronistas, romancistas etc.), o jogo de mostrar e ocultar, a sobreposição de tempos e espaços e o aproveitamento de documentos históricos sobressaem não como novidades, mas como recursos que dão continuidade às estratégias de gerações anteriores.

Palavras-chave: Dramaturgia. Historiografia. Teatro. Identidade. México. 


\begin{abstract}
HASMANN, Robson Batista dos Santos. The weight of History and its characters in Rodolfo Usigli, Vicente Leñero and Sabina Berman's dramaturgy. 2018. 268f. Thesis $(\mathrm{PhD})$ - Faculty of Philosophy, Filology and Human Sciences, University of São Paulo, São Paulo, 2018.
\end{abstract}

This investigation focuses on the building of twentieth century Mexican dramaturgical system and takes as a starting point the relation between dramatic literature and history. The main proposal is to identify fictionalization strategies of historical events and the way they contributed to specific textual and scenic transformations throughout a period that ranges from post-revolutionary years to the beginnings of postmodern era. The study aims to contribute to the history of Mexican dramaturgy considering the researches already carried out by Partida Tayzan (2002a and 2002b), Adame (2004) and Alcántara Mejía (2010). Our corpus is composed by three main contemporary Mexican authors: Rodolfo Usigli, Vicente Leñero and Sabina Berman. From the first, we are mainly interested in his concept of "antihistory" and his nationalist \& critical stances assumed in $E l$ gesticulador and the so-called Trilogy of crowns. Here, the dramatic works are confronted with the paratexts produced when they were staged or published. Next, we search in Leñerós pieces Pueblo rechazado, Martirio de Morelos, and La noche de Hernán Cortés how he rewrote the documents of past or contemporary events. Finally, with Berman's works, Águila o sol, La grieta, and Entre Villa y una mujer desnuda, we see how the insertion of historical facts and cultural elements acquires a new treatment. The observation of fictional strategies in these three cases shows, first, that the appeal to history and historiography harmonizes the system so that the generational succession is marked by the agglutination of devices and aesthetic conceptions. At the same time, the rewriting of history changes in regard to what may be considered historical. From Usigli to Berman, the past as a place of revisiting, grants more and more space to the present and to what remains. Succinctly, we can say that the main thematic change was the replacement of a dramaturgy that sought in the past the explanations for the present by another in which the past elements are dealt with suspicion. As for fictional strategies such as the inclusion of characters-narrators (historians, chroniclers, novelists, etc.), the show and hide game, the overlapping of times and spaces and the use of historical documents, they all stand out not as novelties, but as resources that give continuity to earlier generations procedures.

Keywords: Dramaturgy. Historiography. Theater. Identity. Mexico. 


\section{RESUMEN}

HASMANN, Robson Batista dos Santos. El peso de la Historia y sus personajes en la dramaturgia de Rodolfo Usigli, Vicente Leñero y Sabina Berman. 2018. 268p. Tesis (Doctorado) - Facultad de Filosofiía, Letras y Ciencias Humanas, Universidad de São Paulo, São Paulo, 2018.

Esta tesis investiga la formación del sistema dramatúrgico mexicano en el siglo XX desde la perspectiva de las relaciones entre la literatura dramática y la historia. La principal propuesta es identificar en qué medida las estrategias de ficcionalización de hechos históricos contribuyeron para los cambios textuales y escénicos de un período que va desde los años postrevolucionarios hasta los umbrales de la postmodernidad. El estudio intenta contribuir en la historia de la dramaturgia mexicana, ampliando los límites con los cuales ya trabajaron Partida Tayzan (2002a y 2002b), Adame (2004) y Alcántara Mejía (2010). Para ello, se seleccionan obras de Rodolfo Usigli, Vicente Leñero y Sabina Berman. Del primero interesan las reflexiones acerca del teatro, su concepto de antihistoria y las posiciones nacionalistas y críticas que expresó en El gesticulador y en la llamada trilogía de las coronas. Las obras dramáticas son cotejadas con los paratextos producidos sobre las representaciones o publicaciones. De Leñero se aprovecha su forma de reescribir los documentos de los acontecimientos representados en Pueblo rechazado, Martirio de Morelos y La noche de Hernán Cortés. Y con las piezas Águila o sol, La grieta y Entre Villa y una mujer desnuda de Berman, se observa que la inserción de referenciales históricos y otros elementos culturales gana nuevos recursos ficcionales. La comparación de las estrategias ficcionales en esos tres casos permite afirmar en primer lugar que el constante uso de la historia y de la historiografía harmoniza el sistema dramatúrgico de manera que la sucesión generacional se caracteriza por la aglutinación de los recursos creativos y las concepciones estéticas. A la vez, la reescritura de la historia se transforma respecto a lo que se puede tomar como histórico. De Usigli a Berman, el pasado, en el sentido de un locus de revisitación, se abre cada vez más al presente y a aquello que permanece sin alterarse. En síntesis, podemos afirmar que uno de los cambios temáticos más significativos es la sustitución de una dramaturgia que buscaba en el pasado las explicaciones del presente por otra cuya característica es la crítica a los elementos pretéritos cargados de prejuicio Desde la perspectiva estética, entre los principales fenómenos ficcionales que legitiman la continuidad y la aglutinación están la presencia de personajes-narradores (historiadores, cronistas, novelistas etc.), el juego de mostrar y ocultar, la superposición de tiempos y espacios $\mathrm{y}$, por último, el aprovechamiento de documentos.

Palabras clave: Dramaturgia. Historiografía. Teatro. Identidad. México. 


\section{RÉSUMÉ}

HASMANN, Robson Batista dos Santos. Le poids de l'histoire et ses personnages dans la dramaturgie de Rodolfo Usigli, Vicente Leñero et Sabina Berman. 2018. 268f. Mémoire (Doctorat ) - Faculté de Philosophie, Lettres et Sciences Humaines, Université de São Paulo, São Paulo, 2018.

Cette thèse étudie la formation du système dramaturgique mexicain au XXe siècle, en commençant par la relation entre la littérature dramatique et l'histoire. La proposition principale est d'identifier dans quelle mesure les stratégies de fictionnalisation des événements historiquesont contribué aux transformations textuelles et scéniques d'une période s'étendant depuis les années post-révolutionnaires jusqu'au seuil de la postmodernité. L'étude veut contribuer à l'histoire de la dramaturgie mexicaine tout en tenant compte les recherches déjà menées par Partida Tayzan (2002a et 2002b), Adame (2004) et Alcántara Mejía (2010). Pour cela, il sélectionne des œuvres de Rodolfo Usigli, Vicente Leñero et Sabina Berman. Du premier, ce qui compte sont les conceptions sur le théâtre (surtout le concept d' «anti-histoire») et la position nationaliste-critique assumée dans El gesticulador et dans la trilogie des couronnes. Ainsi, les œuvres dramatiques sont confrontées aux paratextes produis au sujet des scénarios ou des publications. De Leñero, on utilise la façon dont les documents des événements représentés sont réécrits dans Pueblo rechazado, Martirio de Morelos et La noche de Hernán Cortés. Bref, avec les pièces de Berman on vérifie que l'insertion des faits historiques et des éléments culturels se pare de nouveaux atouts. Le rapprochement des stratégies fictives dans ces trois cas permet de constater, tout d'abord, que l'appel à l'histoire et à l'historiographie harmonise le système de sorte que la succession générationnelle est marquée par l'agglutination des ressources et des conceptions esthétiques. En même temps, la réécriture de l'histoire change par rapport à ce qui peut être considéré comme historique. De Usigli à Berman, le passé, en tant que lieu de revisitation, cède de plus en plus de place au présent et à ce qui reste. En termes synthétiques, on peut affirmer que le changement thématique principal a été le remplacement d'une dramaturgie qui cherchait dans le passé les explications du présent par une autre dans laquelle les éléments passés sont abordés avec suspicion. En ce qui concerne la perspective esthétique, des procédures telles que l'insertion de personnages-narrateurs (historiens, chroniqueurs, romanciers, etc.), le jeu de montrer et de masquer, le chevauchement des temps et des espaces et l'utilisation de documents historiques ne se distinguent pas comme de nouveautés mais comme des ressources qui assurent la continuité des générations antérieures.

Mots-clés : Dramaturgie. Historiographie. Théâtre. Identité. Mexique. 


\section{Sumário}

Introdução

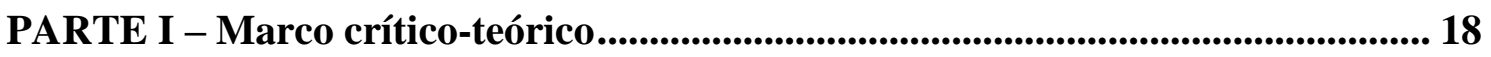

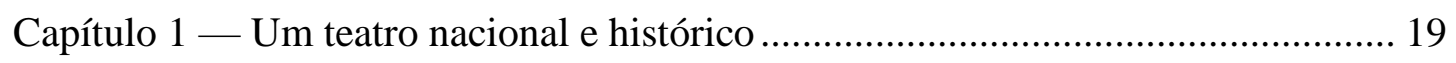

1.1. A história como elemento aglutinador da escrita dramática.......................... 30

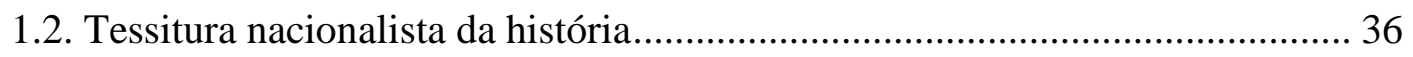

Capítulo 2 - Literatura e história; dramaturgia e teatro ............................................. 43

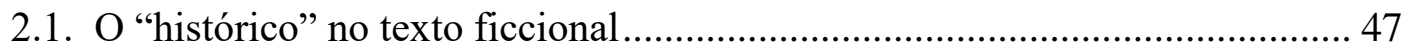

2.2. Os gêneros de extração histórica e a preocupação com a veracidade ............. 53

2.3. Distanciamento e anti-história ................................................................... 58

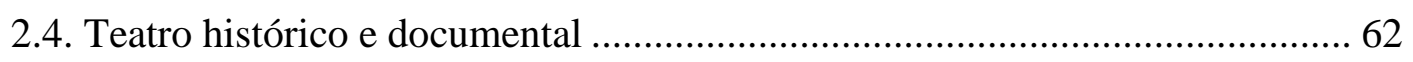

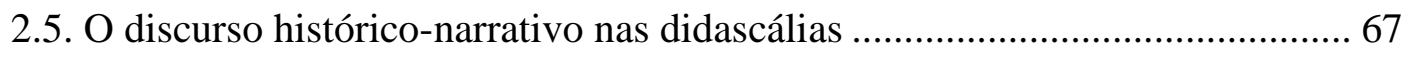

PARTE II - Autores, obras e contexto histórico ..................................................... 74

Capítulo 3 — Rodolfo Usigli: A história descoberta ............................................... 75

3.1. História e educação no projeto de reforma nacional ..................................... 82

3.2. Manipulando e escrevendo a história ........................................................ 88

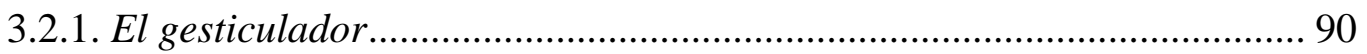

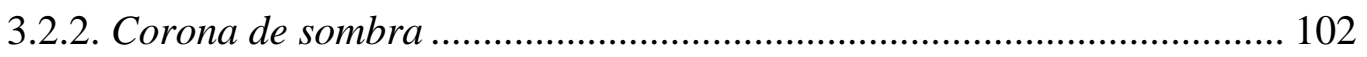

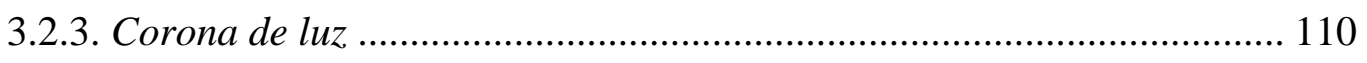

3.3. Anti-história e hipocrisia: enfim um teatro para o México?......................... 122

Capítulo 4 - Vicente Leñero: a história pensada .................................................. 124

4.1. O mexicano: um ser-ante-a-história ........................................................... 126

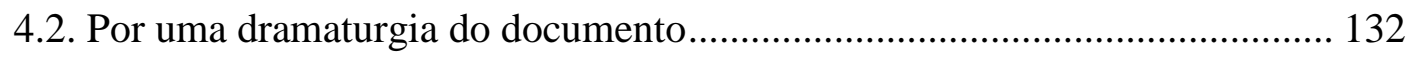

4.2.1. Pueblo rechazado ................................................................................ 136

4.2.2. Martirio de Morelos ............................................................................... 144

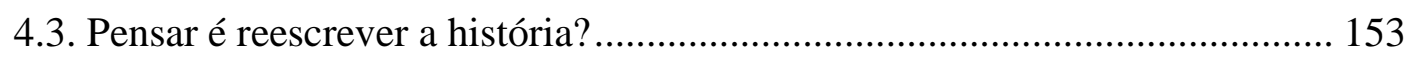

Capítulo 5 - Sabina Berman: A história ressignificada........................................ 156

5.1. Redefinição do nacionalismo no século XX e XXI..................................... 157

5.2. Subversão da arte e da história ................................................................. 161

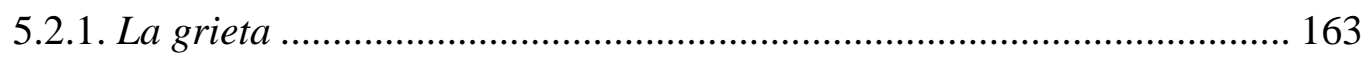

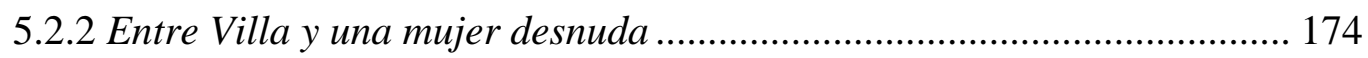


PARTE III - O corpus em perspectiva

Capítulo 6 - Transformações da dramaturgia via didascálias 198

6.1. A narrativa como estratégia de rubrica. 205

6.2. As estruturas narrativas da rubrica e a concepção cênica de uma época....... 211

Capítulo 7 - Representações da Conquista do México .......................................... 213

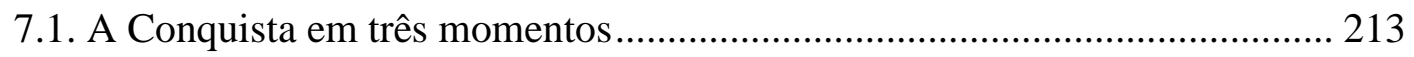

7.2. Montagem e concepção cênica ............................................................... 221

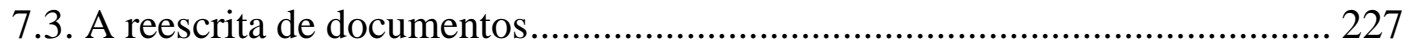

7.4. A relação La Malinche - Cortés .................................................................... 240

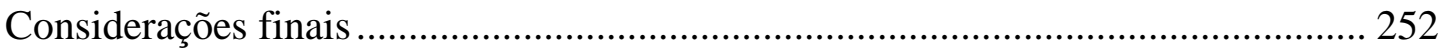

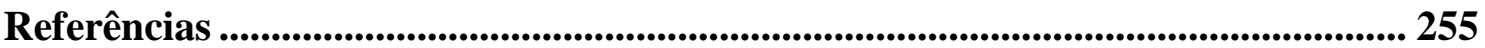




\section{Introdução}

De um modo um tanto superficial, podemos afirmar que a intersecção entre ficção e história se realiza de duas maneiras. Mais diretamente, a interpretação de um drama ou romance envolve a recuperação de conhecimentos históricos a fim de situar o objeto artístico em um panorama sincrônico. Trata-se da verificação da historicidade da obra. Nesse sentido, o enredo, os ambientes, as ações e os próprios temas intrínsecos a ela são cotejados com eventos e assuntos do contexto em que nasceu. Por outro lado, em nível mais profundo, a relação situa-se no plano da representação direta de um evento histórico. Não raro, autores de diversas vertentes estéticas resgatam da historiografia um período ou acontecimento para torná-lo ficcional. Assim, dramas e romances são abarcados em uma categoria peculiar.

Os dramas históricos são composições teatrais cuja arquitetura cênica sustenta-se pela representação de personagens, espaços e tempos consagrados pela historiografia. Vincular essa categoria ao teatro parece paradoxal a priori, uma vez que o elemento caracterizador dessa arte é a confluência temporal entre o tempo do espectador e o dos actantes. Parafraseando as palavras do dramaturgo e crítico espanhol Sanchis Sinisterra, poderíamos afirmar que o teatro é presente e presença.

O paradoxo se desvanece quando resgatamos a etimologia do vocábulo história e mergulhamos na essência do fenômeno teatral. Jacques Le Goff (2003) ensina que na raiz de "história" está aquele que vê, podendo ser estendido para a testemunha. Já o teatro implica ao menos dois participantes, aquele que se mostra e aquele que vê. A similaridade "do mostrar e do olhar" nos autoriza a ver o espectador teatral se transformando em historiador na medida em que assiste à representação de um evento histórico - ou ficcionalizado como tal.

Consequentemente, um dos problemas que se coloca ao identificarmos no teatro um enredo histórico é o dos possíveis efeitos que a peça, principalmente quando retirada do âmbito estritamente literário, pode causar nos espectadores.

Tomando alguns exemplos aleatórios na dramaturgia universal, encontramos momentos em que o drama histórico teve o objetivo de contribuir na formação de uma nação ou de consolidá-la em um período de crise identitária. A dramaturgia portuguesa do século XIX, por exemplo, teria sido forjada sob esses parâmetros, conforme defende Ana Isabel P. Teixeira de Vasconcelos (2005). No Brasil dos anos de chumbo, peças como 
Calabar, de Chico Buarque e Ruy Guerra, e Liberdade, liberdade, de Millôr Fernandes e Flávio Rangel, ilustram como o olhar se volta para a história com o intuito de delatar aspectos do presente.

Ainda sobre os efeitos de sentido sugeridos ao espectador, devemos nos lembrar de que, se a tragédia clássica buscava despertar medo e culpa, isto é, provocar a catarse, Bertolt Brecht (1898 - 1956), por meio do "distanciamento", tinha como alvo o alvorecer da consciência política. Para o "homem de teatro" alemão, o ator deveria ser capaz de abandonar a máscara e historicizar os acontecimentos da cena. Dessa forma, buscando quebrar a ilusão por meio da inserção de elementos épicos (ROSENFELD, 1977), o dramaturgo acreditava cumprir com a missão de engajamento social e político.

Neste trabalho, essas reflexões são convocadas a propósito do contato com a dramaturgia mexicana, em especial com obras e autores situados entre os anos pósrevolucionários e o limiar da pós-modernidade. Conforme veremos no primeiro capítulo, depois das experimentações empreendidas na década de 1920, o surgimento de uma obra ímpar parece ter assentado as bases para as gerações posteriores. A "pieza para demagogos" El gesticulador, escrita por Rodolfo Usigli em 1938, publicada na revista El hijo pródigo em 1943, levada ao palco em 1947 para a inauguração do Instituto Nacional de Bellas Artes, e retirada poucos dias depois da estreia, conjuga ficção e história de uma forma tão intensa que não é possível deixar de verificar de que forma o recurso ecoou em seus conterrâneos até os últimos anos do século XX.

Além desse marco específico, a confluência de teatro com história na cultura mexicana existe de longa data. A relação remete a estratos culturais mais profundos e se manifesta de duas maneiras. Em primeiro lugar, o teatro cumpriu função primordial no processo de colonização. A encenação de passagens bíblicas foi amplamente utilizada para catequizar, educar e doutrinar as nações indígenas. Além dessa forma strictu sensu, outra em sentido lato se desenvolvia concomitantemente naquilo que Leandro Karnal (1998) chamaria "teatro da fé", a saber, a sociedade colonial na Nova Espanha criava rituais para marcar e mostrar a importância da cultura que estava sendo imposta.

Podemos dizer que a história no México é experimentada como fenômeno teatral. Disso surge a segunda manifestação cultural que urde conceitualmente história e teatro: a ideia de que a política, tal qual o teatro, faz-se de mentiras. As acusações do cronista Bernal Díaz del Castillo (partícipe da empreitada de Hernán Cortés em Tenochtitlan) de que Francisco López de Gómara era um mentiroso porque não 
participara dos fatos narrados em sua Conquista do México, exemplificam bem as origens dessa concepção da história que permanece em muitos intelectuais ao longo do tempo.

Rodolfo Usigli e Sabina Berman souberam explorar esse aspecto do imaginário de seu país e o elaboraram ficcionalmente: Usigli, que fez correr as cortinas para que a modernidade teatral fosse vivenciada, estrábico e propenso a polêmicas de toda ordem, lançou nos anos imediatamente pós-revolucionários a proposta de que a renovação teatral em seu país aconteceria desde que se soubesse aproveitar aquela que, para ele, era a principal característica do mexicano: a hipocrisia. Ele elabora essa categoria analítica da teatralidade unificando o significado oriundo do teatro clássico (o ator) com o uso contemporâneo (falso, mentiroso, ardiloso). Já Berman, sem elaborar conceitualmente a questão, a aproveita em La grieta, obra significativa tanto para sua própria trajetória autoral quanto para a dramaturgia de seu país.

Teatro, história, política... Tantos aspectos interligados... Por isso, é preciso sublinhar que, no que tange às análises das obras, separamos o fenômeno teatral entre a escrita dramática e a montagem cênica. Essa separação é válida e necessária, pois, assim como a história moderna conseguiu separar aqueles que fazem a história daqueles que a escrevem (CERTEAU, 1975/1982) ${ }^{1}$, isto é, dos indivíduos que buscam nos documentos os vestígios de uma narrativa cuja ordenação dá sentido ao tempo de uma comunidade ${ }^{2}$, o enfoque desta pesquisa recairá nos elementos literários. Isso não significa, porém, a perda do sentido de completude que se realiza com a encenação.

Com efeito, o objeto deste trabalho é o constante diálogo da dramaturgia mexicana com a história. A permanência da intersecção dessas áreas torna-se peculiar no contexto do sistema literário do México, pois outras expressões artísticas — romances, murais, filmes etc. - também convocam a história com muita recorrência. Não se trata de um recurso extemporâneo, fruto da proposta estética de um autor em uma obra específica, a aparecer de quando em quando. No caso do texto dramático, o procedimento reaparece geração após geração ao longo de todo o século XX.

Decorre dessa constatação o primeiro tópico de observação: quais foram as motivações sócio-culturais fundamentais que proporcionaram a permanência do diálogo

\footnotetext{
${ }^{1}$ Ao longo de todo o trabalho, nas citações em que aparecerem duas datas indicaremos respectivamente o ano da primeira publicação (na língua original no caso de obras traduzidas) e, a seguir, o da edição que utilizamos. Depois da primeira entrada, todas as indicações serão apenas da edição consultada.

${ }^{2}$ Recuperamos de Paul Ricoeur (1983/1994 e 2000/2007) a concepção de que o sujeito, ao ordenar narrativamente eventos passados, dá sentido ao tempo e estendemos à narrativa histórica a possibilidade de realizar o mesmo efeito em uma coletividade.
} 
entre literatura dramática e história? Responder a tal pergunta não implica o levantamento quantitativo do número de peças escritas sob essa perspectiva. Interessa antes verificar, dentro da historicidade de cada um dos autores selecionados, a confluência do pensamento estético com o filosófico-crítico circundante, bem como as formas de proporcionar a criação, produção e circulação dos objetos artísticos teatrais.

Assim, buscamos responder ao questionamento anterior por dois caminhos. Primeiro, traçando os contornos cronológicos das etapas do período estudado, pois para abranger as manifestações surgidas imediatamente após a Revolução até aquelas criadas no ocaso do século XX, é preciso demarcar claramente as nuances. Além disso, como os autores mais representativos perpassam muitas etapas criativas, a necessidade de pontuar os momentos se faz mais premente. Uma vez deslindada a cronologia, recorremos aos ensaios de interpretação da identidade mexicana e aos estudos acadêmicos sobre nacionalismo, porque na cultura mexicana a história cumpre essa função identitária. Preferimos essa abordagem ao levantamento dos eventos históricos porquanto os ensaios e estudos promovem análise crítico-reflexiva acerca dos eventos. Como o pressuposto da investigação é que a interpretação de um acontecimento histórico precede a realização artística da história, parece-nos mais seguro trilhar o caminho das leituras reflexivas já construídas do que apenas identificar os acontecimentos para depois estabelecer os vínculos.

Por isso, a constatação da presença frequente da história nas obras de teatro implica necessariamente estabelecer um recorte. Necessidade, aliás, mais imediata porque só o recorte permite assentar os limites cronológicos das etapas do sistema no período estipulado.

Assim, três sãos os principais autores a compor nosso corpus: Rodolfo Usigli (1905 - 1979), Vicente Leñero (1933 - 2014) e Sabina Berman (1955 - ). Nossa perspectiva é que eles configuram a tríade que mais significativamente representa os pontos de inflexão da dramaturgia mexicana - sobretudo no período estudado. Fator determinante na escolha são suas propostas estéticas por se sustentarem justamente na intertextualidade com a historiografia.

Da obra de cada um deles emergem temas relevantes tanto para a interpretação da história quanto para a construção ficcional. Observamos, para além das diferenças estruturais que suas peças apresentam devido à distância temporal de cada uma, que a história cumpre "prerrogativas" diferentes. Em outras palavras, a abordagem dos eventos históricos para Usigli, Leñero e Berman obedece a princípios morais e éticos 
distintos. Então, a hipótese que pretendemos verificar é a possibilidade da escrita dramática e cênica serem motivadas por mudanças da concepção histórica e da experiência da história (KOSELLECK, 1979/1993). Portanto, acreditamos ser possível observar transformações estéticas que estariam buscando representar as modulações da história em determinado momento do século XX.

Do ponto de vista metodológico, acreditamos que só um movimento pendular de análise possibilitará compreender a dinâmica do enriquecimento ficcional. Por esse motivo, em um primeiro momento, analisamos individualmente cada autor e algumas de suas obras. A seguir, escolhemos peças nas quais se aborda um tema comum (a Conquista do México) e as cotejamos. Esse movimento analítico tem o objetivo de responder a outras fortes indagações: com quais estratégias ficcionais discute-se a história do país? Essas estratégias auxiliariam a forjar a própria teatralidade das peças?

O trabalho se divide em três partes. Na primeira são discutidos inicialmente os marcos teórico-críticos em torno da história da dramaturgia mexicana. Nessa etapa, dialogamos com Armando Partida Tayzan (2002a e 2002b), Domingos Adame (2004) e José Ramón Alcántara Mejía (2010), cujas pesquisas são pautadas pela dimensão cronológica do sistema dramatúrgico. Nesse sentido, devemos enfatizar os aportes oriundos da sociologia e da história da literatura, com os quais apresentamos um quadro panorâmico-crítico das gerações no teatro do século XX. Para isso, recorremos aos pressupostos de Antonio Candido (1975/2000a, 1965/2000b) sobre a formação de sistemas literários. Já para compreender o drama histórico e outras expressões dramáticas que dialogam com a história, resgatamos de György Lukács (1937/2011) os fundamentos da formação desse gênero e de Peter Szondi (1956/2001), as transformações geradas pela crise do drama. Com esses referenciais, recorremos também às reflexões sobre os gêneros literários pautados por enredos retirados da historiografia e sobre o papel da didascália na concepção cênica a fim de verificar a eficácia da inserção de elementos históricos nas obras pesquisadas.

Ainda na primeira parte, o segundo capítulo traça um panorama das discussões sobre nacionalismo com intuito de o relacionar aos conceitos e tópicos iniciais. A preocupação fundamental é estabelecer parâmetros de análise que auxiliem na compreensão das formas de se usar a história com finalidades políticas. Por isso, discutimos conceitos como "histórico" enquanto objeto de estudo da ciência historiográfica ou temática ficcional, distanciamento, anti-história, teatro documental e formas narrativas da rubrica. 
$\mathrm{Na}$ segunda parte, realizamos o primeiro movimento analítico-crítico. Os dramaturgos selecionados são estudados separadamente, com a seguinte sistemática: 1) apresentação do/a autor/a e da trajetória literária; 2) investigação do contexto histórico, político, cultural e econômico por meio de ensaios de interpretação da identidade e/ou de estudos de revisão da história; 3) seleção e análise de obras significativas, sobretudo aquelas vinculadas diretamente ao entrecruzamento entre literatura e história.

Finalmente, na terceira e última parte estabelecemos o segundo movimento analítico-crítico. As obras sobre a Conquista do México escritas por Usigli, Leñero e Berman são vistas em conjunto, focando em quatro pontos: a produção e montagem, a recepção crítica do momento em que foram montadas, a relação com os documentos e a representação do casal histórico Malinche-Cortés.

Pela exposição das partes, pode-se perceber que não se trata de uma pesquisa que visa a (re)interpretar eventos históricos por vias da dramaturgia, mas de encontrar aspectos que permitam observar as mudanças estéticas provocadas pela reflexão sobre elementos culturais, a partir do diálogo com a história e a historiografia. 
PARTE I - Marco crítico-teórico 


\section{Capítulo 1 - Um teatro nacional e histórico}

Nosso objeto de estudo, as relações entre a dramaturgia mexicana do século XX e a história a partir da observação de três dramaturgos contemporâneos, ganhará maior profundidade se esboçarmos antes uma breve e aproximativa história do teatro mexicano nesse período. A brevidade, porém, não visa à catalogação de obras, autores e grupos. A problemática que move essa elaboração historiográfica inicial decorre, primeiramente, do próprio objetivo do trabalho, isto é, apresentar as transformações da escrita dramática entre os anos de 1940 e 1990. De fato, sem a visão do todo, as referências a dramaturgos e peças provavelmente atrapalharão mais do que contribuirão quando na segunda Parte esmiuçarmos as peculiaridades de cada etapa e autor. Outro motor relevante é que a maioria dos trabalhos que se propõe a abordar esse teatro sob uma perspectiva histórica recorta as etapas e/ou tendências, pois não tem o intuito de abranger todo o século $\mathrm{XX}^{3}$. Portanto, nesta abertura optamos por demonstrar quais as linhas dominantes da dramaturgia do período a partir de estudos críticos e das perspectivas assumidas pelos próprios autores na medida em que tentam se inserir a uma tradição de seu país.

Com efeito, a problemática inicial que as observações anteriores demandam é a de saber se existe um teatro mexicano. A questão foi formulada ao longo de todo o século XX, com maior ou menor intensidade. O corolário da pergunta manifestou-se ora pela rejeição da própria ideia de "teatro mexicano", ora pela defesa veemente da necessidade de se aliar a arte dramática à nacionalidade. Em outras palavras, enquanto alguns dramaturgos advogavam em favor da tese de que não havia necessidade de acrescentar o adjetivo pátrio ao substantivo, outros procuravam de todo jeito demonstrar que um aspecto da identidade nacional se daria com a construção de uma arte dramática autêntica.

Essa dicotomia, que de certa forma constitui os debates entre tradição $v s$. vanguarda, regionalismo vs. cosmopolitismo, universal vs. local etc. — problemática tão arraigada na literatura hispano-americana —, circula pelo tempo e pela mentalidade de

\footnotetext{
${ }^{3}$ O destaque fica para os estudos de Burgess (1991), Partida Tayzan (2002b), Adame (2004) e Alcántara Mejía (2010), autores com os quais dialogamos logo abaixo. Remetemos também à pesquisa de mestrado defendida na Universidade de São Paulo, em cujo primeiro capítulo mapeamos, desde os anos 20, as experimentações teatrais dos grupos que antecederam Poesía en Voz Alta, em meados dos anos 50: Do paraíso à solidão: modernidade em La hija de Rapaccinni de Octavio Paz (HASMANN, 2013).
} 
dramaturgos e críticos desde as primeiras manifestações de vanguarda das décadas de 1920 e 1930 até os umbrais da pós-modernidade.

Para se ter uma dimensão da presença desses temas no panorama da dramaturgia do México, trazemos à baila, em primeiro lugar, as reinvindicações de Víctor Hugo Rascón Banda (1948-2014) em meados de 1980. ${ }^{4}$ Ele, então um jovem autor, realizando uma espécie de ensaio-manifesto a favor da chamada Nova Dramaturgia Mexicana, questionava a ideia, frequentemente retomada, de que em seu país não existia teatro por falta de dramaturgos. "Y sucedió que un día, alguien dijo 'no hay dramaturgos en México' y muchos repitieron lo dicho y de tanto oírlo, llegaron a creerlo.” (1985, p. 89). Segundo ele, os argumentos elencados para justificar essa opinião eram sempre interessados. Os diretores de companhias de teatro estatais recorriam a ela para inserir obras estrangeiras nos repertórios. As universidades se apoiavam nela para levar aos palcos adaptações de romances. Por fim, a frase "no hay dramaturgos" servia aos empresários do ramo para justificar a importação de apresentações de sucesso em Nova Iorque.

O ensaio-manifesto dos anos 1980, além de apresentar alguns autores e características da geração que então aparecia no cenário, a dos Novos Dramaturgos, abria espaço para pensar problemas oriundos de décadas anteriores. A priori saltam à vista aqueles ligados à montagem das peças, às formas de financiamento estatal e às negociações dos autores com os produtores culturais, públicos e privados. Todos esses problemas tinham começado a aparecer em meados dos anos cinquenta com os autores dramáticos da chamada “Generación del Medio Siglo”. Nesse momento, as manifestações teatrais espontâneas das décadas de 20, 30 e 40 já se integravam a um sistema de produção e recepção articulado ${ }^{5}$. Outra questão que aflora das entrelinhas do texto de Rascón Banda, embora com menor intensidade, é o conflito entre a ideia de um teatro de autor e a de um teatro de diretor, debate que se intensificou nos anos 70 .

De todos os temas que o ensaio-manifesto do escritor chihuahuense condensa, talvez o mais simbólico, capaz de mais fortemente comprovar a permanência da busca por aliar uma escrita dramática a um empenho de formação nacional, advenha das últimas palavras:

\footnotetext{
${ }^{4} \mathrm{O}$ ensaio, retirado de uma das edições da Latin American Theater Review de 1985, apareceu inicialmente em La brújula del bolsillo, uma das revistas mexicanas direcionadas às artes cênicas nessa mesma década. ${ }^{5}$ Tomamos de Antonio Candido os pressupostos da Formação da literatura brasileira (2000a) e Literatura e sociedade (2000b). São essas as premissas que encorajam a formulação deste histórico.
} 
La dramaturgia mexicana está viva y saludable. [...] La dramaturgia mexicana subió a los escenarios y a veces, con voz destemplada, a veces, con voz fuerte, a veces, en un susurro, dijo, aquí estoy y aquí me quedo, y desde aquí se oirá mi voz, para que, como lo escribiera un dramaturgo, "el pueblo vea su propio gesto, oiga su propia voz y viva el torrente dramático de su propia circunstancia, para que le plasmen sus sueños propios y la pesadilla de su propia historia” (RASCÓN BANDA, 1985, p. 92). ${ }^{6}$

O trecho destacado na citação, apesar de estar entre aspas, não foi retirado de outro texto. Rascón Banda está, na verdade, imaginando o que teria escrito "um dramaturgo", cujo nome também não revela, mas que pode ser facilmente inferido. As formulações de que o povo deve ver "o próprio gesto", “ouvir a própria voz" para "plasmar a própria história” evocam, sem sombra de dúvida, as lutas que Rodolfo Usigli tinha empreendido desde a década de 30.

Entre Usigli e Rascón Banda existe um fosso de duas gerações. Com efeito, como compreender, sob o ângulo da história da dramaturgia, a proximidade de suas ideias? Nossa percepção é de que o fato pode ser explicado por uma continuidade das ideias, pela permanência de "notas dominantes" (CANDIDO, 2000a), típicas desse processo entendido como sistema dramatúrgico mexicano.

Como sucede nos sistemas literários, a confluência entre o momento político, econômico e cultural dos autores impactaria as noções de identidade e teatro nacionais. De maneira geral, à medida que a criação das obras se afastava dos tempos revolucionários e se aproximava da pós-modernidade, o relacionamento com a história e a historiografia ganharia contornos diferentes, mas a questão da existência ou não de um teatro mexicano sempre esteve em pauta, com maior ou menor intensidade.

Rodolfo Usigli, o dramaturgo citado de forma velada por Rascón Banda e sobre cujo pensamento e obras refletiremos atentamente mais adiante, é considerado o grande mentor do teatro moderno no México. Ele havia expressado algo muito semelhante logo nos primeiros anos de sua produção. Em 1933, no Prólogo à Bibliografía del teatro en México, de Francisco Monterde ${ }^{7}$, o autor de El presidente y el ideal opinava sobre os

\footnotetext{
${ }^{6}$ Ao longo de todo este trabalho, utilizaremos o negrito dentro de algumas citações a fim de sublinhar o que de mais importante nos interessa. Dessa forma, a menos que haja indicação contrária, os negritos serão todos nossos. Apesar da aparente redundância, consideramos que as partes não destacadas se configuram como contextualização do aspecto para o qual damos mais importância.

${ }^{7}$ O livro de Francisco Monterde, o primeiro do gênero escrito no México, tinha por volta de 649 páginas. Trazia informações sobre quase duas mil peças representadas na capital e nos demais estados desde o século XVI, com dados do autor e da montagem. Em 1934, o Prólogo de Rodolfo Usigli, republicado em Monografías Bibliográficas Mexicanas, passou a chamar-se "Caminos del teatro en México", título com
} 
empecilhos para o pleno desenvolvimento do teatro em seu país. Sua perspectiva era que existiam autores dramáticos em quantidade e qualidade suficientes, mas que faltava uma infraestrutura capaz de absorver e dar vazão a suas obras: "En México carecemos de un buen conservatorio, de teatros modernos y de vida teatral, no de autores. El gobierno que lo medite bien sabrá remediar esta falta." (USIGLI, TC IV, p. 265). ${ }^{8}$

Guardadas as diferenças contextuais de um e outro autor, a referência de Rascón Banda a Usigli e a afirmação de ambos de que a inexistência de dramaturgos não poderia ser argumento para a carência de montagens de peças nacionais oferecem subsídios para detectarmos uma sintonia bastante sintomática no modo de configuração do sistema dramatúrgico de seu país.

Ambos os autores também denunciavam o tratamento comercial dado ao teatro e defendiam que essa postura fosse substituída por outra, mais comprometida com os rumos da arte nacional. No "Ensayo sobre la actualidad de la poesía dramática", de 1947, Usigli afirmava que,

independientemente de sus capacidades imaginativas y de su sensibilidad naturales, que debe someter a un ejercicio infinito para afinarlas y llevarlas a la penetración y realización del viejo desiderato de verdad y belleza, el escritor creador tiene otras obligaciones ineludibles hacia su profesión: continuar, renovar u originar la línea de una tradición literaria propia de su país y de su idioma. (USIGLI, TC III, p. 522).

Na mesma "linha”, Rascón Banda parece seguir essa “tradição":

[los autores] saben que todo lo que hagan debe tener un sentido y una orientación y que, después del compromiso de todo autor, que consiste en escribir bien, debe existir algo más, una solidaridad con los otros, los muchos, los marginados, los que nada tienen; se dan cuenta que en un país como el nuestro no pueden darse el lujo de hacer teatro bonito, de buen gusto, de ése que la gente ve, en un cómodo y ostentoso lugar y sale feliz exclamando qué bien la pasamos, qué decorados, qué joyas, qué terciopelos, qué peinados, qué elegancia ... (RASCÓN BANDA, 1985, p. 90).

Embora em uma primeira leitura as citações pareçam apontar para questões diferentes, é possível uma aproximação das ideias de Usigli e Rascón pelo que está nas entrelinhas: a consciência do papel do autor em seu tempo. Para o primeiro, vivendo em um contexto de reformulação da nacionalidade, a continuidade da tradição teatral

que se reconhece sua importância entre os ensaios e estudos que visam à construção de uma historiografia do teatro. A versão que aparece no Volume IV das obras completas do dramaturgo é a de 1934.

${ }^{8}$ A obra completa de Rodolfo Usigli está publicada em quatro volumes. Visando facilitar a localização das peças e ensaios, optamos por indicar o volume no qual os leitores podem ter acesso aos textos referenciais. 
significa resgatar da história não apenas os elementos estético-formais, mas também os temas. Já para o segundo, a postura engajada de auxílio aos excluídos pode ser lida também como preocupação com a nacionalidade a partir dos indivíduos.

As semelhanças entre as ideias de Usigli e Rascón Banda nos impeliram à busca de estudos críticos da dramaturgia mexicana com enfoque historiográfico. Observamos que, não raro, os estudiosos — os quais analisaremos a seguir — recorrem ao conceito de geração, selecionando alguns dramaturgos e obras de maior projeção, para instrumentalizar a observação dos temas e recursos técnicos comuns e, consequentemente, realizar uma classificação dos autores em uma categoria geracional. Essa prática, oriunda de uma concepção narrativaista da história, parece-nos insuficiente.

A construção historiográfica da dramaturgia mexicana pautada pelo critério geracional apresenta pelo menos dois entraves. O primeiro é o da distância temporal do nascimento entre um/a e outro/a autor/a. Um caso emblemático é o dos/as integrantes da Nova Dramaturgia. Urtusástegui nasceu em 1933, Rascón Banda é de 1948 e Sabina Berman, de 1955. Arriscaríamos dizer que dentro de uma mesma geração artística se localizam autores de gerações diferentes no que tange aos costumes e ao contexto histórico. Outro entrave é o da frequente longevidade da produção de cada dramaturgo. O caso de Rodolfo Usigli ilustra bem a questão. Começou a produzir e montar em 1933, mas a última obra, ¡Buenos días, señor presidente!, é de 1972, quando ele ainda ministrava aulas de escrita dramática. Nesse mesmo ano, os novos dramaturgos Rascón Banda e Sabina Berman, começavam a frequentar as oficinas de escritura de Hugo Argüelles. Outros casos são os de Emilio Carballido e Vicente Leñero, cujas primeiras obras são das décadas de 50 e 1960, e viveram e produziram até 2008 e 2014, respectivamente.

Dentre os estudos que abordam a dramaturgia sob uma ótica histórica, destacamos primeiramente os de Armando Partida Tayzan (2002a e 2002b). O crítico e professor da Faculdade de Filosofia e Letras da Universidade Autônoma do México (FFyL - UNAM), partindo de Ortega y Gasset, para quem uma geração abarca uma série de condicionantes sócio-históricos que produzem características comuns, empreendeu em Se buscan dramaturgos I e II uma sistematização geracional dos dramaturgos da segunda metade do século XX. No primeiro volume, que é uma compilação de entrevistas realizadas com 45 autores, faz um estudo prévio cujos resultados demonstram que existiria "más que una ruptura, una continuidad" (PARTIDA TAYZAN, 2002a, 71) entre os escritores das diferentes gerações. 
Essa e outras considerações finais são retomadas no segundo volume. Para Partida Tayzan (2002b), a marca principal do período teria sido a passagem de um modelo "aristotélico" para outro "não aristotélico". Em sua acepção, os termos designam, no primeiro caso, expressões teatrais pautadas pela unidade de ação, tempo e espaço, e, no segundo, as inovações conquistadas pelo teatro do Absurdo e o de Brecht.

Um aspecto que o crítico não aborda diretamente, mas que pode ser entrevisto ao longo do trabalho e de alguns questionamentos feitos nas entrevistas, é que nessa passagem permaneceria o vínculo entre a dramaturgia e o sentimento nacional. Isso é se mostra claramente em um dos subcapítulos do segundo volume. Com o título de "Hacia uma dramaturgia nacional no aristotélica" (PARTIDA TAYZAN, 2002b, p. 13), o estudo nos autoriza a enxergar o elo que acreditamos ser a ponto nevrálgico da história da dramaturgia mexicana.

Além desse pesquisador, merecem destaque também as pesquisas de Domingo Adame (2004) e José Ramón Alcántara Mejía (2010), que procuraram construir uma historiografia literária com operadores diferentes do conceito de geração.

Adame fundamenta-se no pressuposto de que o teatro organiza diversos códigos culturais emanados da própria cultura que pretende representar e transformar. Por isso, em uma comunidade marcada pela pluralidade de códigos como a mexicana, mais que "teatro" se deveria usar o termo "teatros" e "teatralidades" (este último conceito entendido como "la capacidad del individuo para transformar la realidad a través de su propia transformación" - ADAME, p. 10).

Esse sentido totalizante assumido pela perspectiva teórica do pesquisador motiva a criação de um estudo no qual cabe tudo, e nada deve ser esquecido. Por isso, surgem múltiplas referências aos movimentos teatrais e aos dramaturgos da cultura ocidental. Entre os mexicanos, o trabalho elenca um grupo de autores muito próximo daquele que já tinha sido estabelecido pelo cânone literário, incluindo até mesmo Octavio Paz, autor de uma única peça (La hija de Rappaccini, de 1956), e Carlos Fuentes, cujos textos dramáticos se situam em posição inferior, se comparados à força expressiva de seus romances.

Outro pressuposto de Adame assenta-se sobre a ideia de que o teatro seria um subsistema dentro de um sistema cultural. "En este sentido siempre operan simultáneamente las condiciones históricas, políticas y sociales por un lado y las tradiciones por otro." (ADAME, p. 67). Em outras palavras, o estudo dos subsistemas culturais deve considerar o cruzamento de sincronias (condições histórico-político-sociais) 
e diacronias (as tradições). Para o autor, esse segundo elemento é sinônimo de popular; assim, sutilmente difere da reivindicação de Usigli e de Rascón Banda ${ }^{9}$, para os quais a tradição representava a herança dos dramaturgos anteriores. Por isso, ao mencionar as teatralidades do México, Adame debruça-se primeiramente sobre as manifestações teatrais indígenas, do passado e do presente.

São cinco as formas de teatralidades no México, segundo o autor: "teatro indio y comunitario", "revista y carpa", "teatro educativo y de orientación popular", "teatro dramático" e "teatro de experimentación escénica e investigación". Ele explica cada uma delas, apresentando um catálogo com nomes, lugares, técnicas cênicas etc. A despeito da importância dessas tendências, interessa-nos a que ele explora no último capítulo, sobre o teatro dramático definido com estas palavras:

[es] aquél que designa al teatro occidental de origen burgués implantado a partir del siglo XIX, cuyas características son: representación en un teatro "a la italiana" de un drama que trata asuntos de la vida individual o social desde la perspectiva de la clase dominante y con intención mimética, tiene como soporte al texto, por lo que su fuerza descansa en la estructura de la fábula que busca envolver al espectador. (ADAME, 2004, p. 133 - aspas do autor).

A seguir, divide essa teatralidade em três paradigmas: mimético, "basado en la semejanza de lo que se representa con lo representado"; o anti-mimético, que "busca proyectar sobre lo representado la percepción interna que se tiene del fenómeno observado"; e o pós-moderno, "que muestra el funcionamiento paradójico, inestable y artificial de la construcción teatral, haciendo imposible fijar un sentido a la obra". (ADAME, p. 207 - ênfase do autor). A apresentação sintética dos conceitos permite operacionalizar a leitura de algumas obras representativas dos paradigmas. No entanto, se lido com mais rigor, identificamos que o estudo detecta, principalmente no ponto em que o pesquisador inicia a parte analítica, a falta de clareza no que diz respeito à seleção das obras, embora seja possível inferir que a escolha obedece a dois critérios.

O primeiro é o cronológico, ou seja, determinado pelo ano de escrita e/ou de montagem da peça, pois o paradigma mimético é representado por Moctezuma II, de Sergio Magaña, cuja estreia foi em 1953; dentro do segundo paradigma, o anti-mimético, Domingo Adame seleciona Olímpica, de 1964, e In Memoriam, de 1975, ambas de Héctor

\footnotetext{
${ }^{9}$ Para se compreender mais claramente o vínculo que Domingo Adame estabelece entre tradição e o universo popular, podemos afirmar que suas considerações se aproximam da concepção de México profundo, trabalhada pelo antropólogo Guillermo Bonfil Batalla (2010).
} 
Azar, e o Retablo del gran relajo, de Hugo Argüelles, de 1983. Por fim, representam o paradigma pós-moderno, Vicente Leñero, com Nadie sabe nada, levada ao palco em 1988, La noche de Hernán Cortés, de 1992, e Los enemigos, estreada em 1989, com uma “dramaturgia" co-produzida por Lorena Maza, Luis de Tavira, David Olguín e Tolita Figueroa a partir de uma peça homônima de Sergio Magaña cuja escrita baseou-se em Rabinal Achí, obra maia considerada a mais antiga dramaturgia do continente americano ${ }^{10}$. Outro critério de seleção de Adame (2004, p. 207), o da temática histórica, pode ser deduzido das palavras com que ele abre o estudo sobre Sergio Magaña:

No deja de llamar la atención el hecho de que la dramaturgia contemporánea en México, a partir de 1950, dedique un reducido espacio a las obras con el tema de la "Conquista" [...] ¿A qué obedece el "desinterés" de los dramaturgos mexicanos a la segunda mitad del siglo XX sobre tan relevante tema? ¿Acaso es un asunto poco o difícilmente teatralizable?

E finaliza sem resposta: "Probablemente cada respuesta tendría a su parte de razón." Podemos inferir muitos temas relevantes para nossa pesquisa a partir do problema levantado aqui, uma vez que apontam para sintomas muito pertinentes sobre a presença da história na dramaturgia.

Poderíamos nos perguntar por que o tema da Conquista "tem que estar" tão vinculado ao paradigma mimético? Se o princípio que organizava até então o trabalho era o das teatralidades, ou seja, das formas e técnicas dramáticas que demonstravam la capacidad del individuo para transformar la realidad" (ADAME, p. 10), por que o tema da Conquista passa a ser tão relevante? Aliás, as peças escolhidas para representar os paradigmas possuem, em maior ou menor intensidade, enredos de fundo historiográfico. Seja na reformulação da narrativa de um evento histórico, seja na releitura de obras canônicas, seja, enfim, na interpretação de elementos da cultura mexicana, o corpus de Adame apresenta uma constante na dramaturgia de seu país do século XX que ele parece tomar como "natural": o diálogo entre a literatura (dramática ou não) e a história.

\footnotetext{
${ }^{10}$ As aspas usadas por Domingo Adame indicam que o texto dramático foi secundário na montagem. Segundo o pesquisador, "la relevancia de esta representación reside en que no se hizo la ilustración de una pieza dramática, sino una auténtica traducción a la teatralidad escénica de las pertinencias dramáticas de la obra." (ADAME, 2004, p. 250). Por ele não ter aprofundado a discussão, não fica claro como uma montagem que não segue meticulosamente o texto pode estar inserida em um teatro cuja força se sustenta no texto e na fábula. Seria a desobediência ao texto uma marca da pós-modernidade teatral? Ficamos sem respostas por parte do autor...
} 
Apontadas as dificuldades metodológicas no estudo, sentimos que ele convida mais a questionamentos do que a respostas para a formulação de um histórico do sistema dramatúrgico no México que não se paute exclusivamente pelo critério cronológico. Muitos desses aspectos encontram acolhida nas propostas de José Ramón Alcántara Mejía em Teatro y teatralidades en México, siglo XX (2010). Segundo este pesquisador da Universidad Iberoamericana, o mérito de Adame recai na capacidade de detectar que as histórias geradas pelo centro hegemônico da cultura ocidental (Europa e Estados Unidos) não seriam suficientes para abarcar a complexidade das manifestações teatrais no México ${ }^{11}$. Portanto, suas expressões devem ser aprofundadas observando-se as texturas e teatralidades especificamente mexicanas.

A proposta de Alcántara Mejía é elaborar uma teoria teatral mexicana. Para isso, unifica os conceitos de textualidade e teatralidade. Reconhece que o primeiro, enquanto categoria que ultrapassa as designações representacionais e materiais da escritura, não basta para operacionalizar a interpretação das manifestações teatrais de seu país. Da mesma forma, a teatralidade, entendida como indicações dos gestos e ações expressas pela didascália (ou, às vezes, nos casos de obras metadramáticas pelas próprias personagens ), não alcança a totalidade do fenômeno teatral por se limitar demasiadamente aos códigos encenados e colocar a literatura em segundo plano. ${ }^{12}$ Argumenta, por último, que tanto uma quanto a outra, tomadas isoladamente, não seriam suficientes para analisar o fenômeno em seu país porque no teatro mexicano a arte dramática solidificou-se sobre os pilares da identidade e da construção da Nação. ${ }^{13}$ Em suma, o pesquisador oferece o termo textralidad: ${ }^{14}$

Textralidad como neologismo es un híbrido que llama la atención sobre la inscripción de un tejido en otro tejido, de un texto en otro texto. No se trata simplemente de una intertextualidad, ya que son textos de diferente naturaleza, incluso materialmente hablando, pues uno es lenguaje verbal y, el otro, acción, sin contar el otro lenguaje constituido por objetos. Dicho de otro modo, se trata de un injerto en el cual la escritura es transformada en su misma naturaleza al tejerse en ella otro tejido constituido por acciones, sonidos, espacios, formas,

\footnotetext{
${ }^{11}$ Acreditamos que a escolha de Partida Tayzan (2002) por estabelecer o corte entre dois grandes momentos do teatro mexicano usando os termos "aristotélico" e "não aristotélico" em lugar de conceitos como "épico" e "absurdo" se assemelhe a essa opinião de Alcántara Mejía.

${ }^{12}$ Chamamos atenção para as diferenças conceituais com que Domingos Adame e Alcántara Mejía usam o termo "teatralidade". Enquanto o primeiro usa-o desde uma perspectiva sócio-discursiva, o segundo tomao em sentido técnico e gráfico do texto.

${ }^{13} \mathrm{O}$ uso da maiúscula é comum em todo o estudo de Alcántara Mejía.

${ }^{14}$ Por se tratar de um conceito não consolidado ainda na e pela crítica teatral mexicana, optamos por manter o itálico (que permanece em todo o livro de Alcántara Mejía) e, por não encontrar eco em outros espaços críticos, manteremos o espanhol.
} 
cuya constitución ocurre desplazándose en el tiempo y en el espacio.(ALCÁNTARA MEJÍA, 2010, p. 22).

Ao contrário de Adame que, sem se manifestar abertamente sobre a importância que as obras de enredo historiográfico exerciam na consolidação do teatro mexicano, Alcántara Mejía parte do princípio de que o debruçar-se sobre a nação é um aspecto que perpassa a formação do sistema teatral mexicano. Seu foco, porém, não é o século XX, mas os autores e obras já da pós-modernidade. Mesmo retomando sinteticamente os experimentos das três primeiras décadas e pelas ações e projetos de Celestino Gorostiza e Rodolfo Usigli, Alcántara Mejía seleciona autores e obras que, para ele, "reterritorializam a Nação" por meio da textralidad. Todos da Nova Dramaturgia. De Óscar Liera seleciona El jinete de la Divina Providencia (1985) devido à sua capacidade de explorar um tema regional, restrito ao ambiente mais recôndito do México e mostrar nele os problemas nacionais e universais. De Hugo Salcedo (1964 - ), toma El viaje de los cantores, publicada e montada em 2002, mas escrita por volta dos últimos anos da década de 1980. Salcedo trabalha com o tema da migração. Segundo o crítico da Universidade Iberoamericana, a geração desse autor, chamada já de Novíssima Dramaturgia Mexicana, busca "superar el callejón sin salida" em que havia se metido a geração dos anos 70, embora sem explicar em que consistiria esse callejón. A marca dessa geração seria "el rescate del texto dramático y de la referencialidad histórica como eje estructurado a la textralidad”. (ALCÁNTARA MEJÍA, p. 105).

A conexão entre a referencialidade história e a textralidad deve ser enfatizada considerando que, para ele, a história parece ser uma categoria absoluta que, uma vez conhecida, por si só, permite formar a nação. Como veremos mais adiante, ainda neste capítulo, na ideia de nação subjazem inúmeras categorias das quais a história é mais uma. Mesmo assim, esse ponto de partida de Alcántara Mejía é mais uma manifestação intelectual que nos oferece chaves para conceber a história como uma categoria especialmente significativa em vários âmbitos da vida mexicana. Dessa forma, sublinhamos nossa proposta de verificar em que medida essa categoria se enraíza em sua literatura dramática.

Na sequência, são estudados Víctor Hugo Rascón Banda e Jesús González Dávila. Do primeiro, destaca La mujer que cayó del cielo (estreada em 1999 e publicada no ano seguinte). Para o pesquisador, a peça possui uma estrutura simbólica de grande concentração de um acervo cultural arcaico e outro humano que o precede. Em outras 
palavras, o trabalho com os elementos culturais e históricos existiria na medida em que articula estruturas profundas do inconsciente humano e mexicano. De González Dávila, escolhe Quién baila mambo, de 1999, ano de seu falecimento. Em síntese, o que interessa dele para Alcántara Mejía é "la tendencia del autor hacia las estructuras míticosimbólicas" a qual "impide que su obra quede encasillada en un burdo realismo social”. (p. 123).

Como percebemos, os autores e obras do corpus de Alcántara Mejía integram uma das vertentes de maior expressividade no teatro mexicano contemporâneo, a chamada dramaturgia de fronteira ou do Norte. Segundo explica Rosa María Saénz Fierro (2012, p. 9), as manifestações culturais que são designadas como teatro de fronteira cobrem uma grande faixa do norte do país e dos estados de Durango e Sinaloa. Poderiam, ainda, ser acrescentadas as expressões teatrais que ocorrem nos Estados Unidos e em outros locais no interior do próprio México.

É interessante notar que em duas antologias consultadas sobre esse teatro, uma sob a coordenação de Rosa María Sáenz Fierro, Teatro del Norte / Teatro de frontera: antología de ensayos y ponencias (2012), e outra de Roberto Ransom Carty, Antología de ensayos teatrales (2013), os autores mais estudados são justamente Óscar Liera, Hugo Salcedo e Víctor Hugo Rascón Banda. Eles três compartilham o fato de terem se formado na Capital, mas se deslocado para as províncias. Outro aspecto comum é que o tratamento da realidade busca expressões ritualísticas e simbólicas, ainda que os enredos surjam de materiais "concretos", divulgados na mídia. No entanto, trata-se de realidades tão cruéis, de uma brutalidade tão opressora (ilegais que morrem sufocados em um vagão de trem, uma mulher tarahumara que permanece dez anos em coma em um hospital em Kansas sem que ninguém saiba sua origem, uma menina que abandona o lar para viver da venda do corpo na fronteira norte do país) que fica difícil enfrentá-las com as mesmas ferramentas do realismo social. O tratamento estético dado por esses dramaturgos que viveram as transformações e desilusões da modernidade na capital se pauta por parâmetros de teatralidade altamente inovadores. Eles representam um novo ciclo na dramaturgia ainda em construção, que está, como aponta Rocío Galicia (2012), do Centro de Investigaciones Teatrales Rodolfo Usigli, em constante movimento.

Em síntese, podemos dizer que os trabalhos de Partida Tayzan (2002a e 2002b), Adame (2004) e Alcántara Mejía (2010) efetuam satisfatoriamente uma historiografia da dramaturgia. As três pesquisas, com foco em questões e tempos específicos, que nos convidam a verificar os diversos elementos e aspectos que 
conformaram a modernidade teatral dos últimos cem anos. A opção neste estudo é de trabalhar com o período dos anos pós-revolucionários até a entrada na pós-modernidade a partir do olhar sobre uma temática cuja presença se verifica como uma constante: a de tramas, personagens e eventos oriundos da história mexicana.

\subsection{A história como elemento aglutinador da escrita dramática}

O exame da bibliografia comentada no tópico anterior mostra que os estudos acadêmicos que olham o teatro mexicano em perspectiva carecem de unidade, apesar do propósito totalizante (é o caso de Domingo Adame), ou focalizam gerações específicas (Armando Partida Tayzan ao tratar da Nova Dramaturgia ${ }^{15}$ ) ou, ainda, buscam compreender as expressões mais contemporâneas (José Ramón Alcántara Mejía). Nossa perspectiva, sem abandonar a cronologia do surgimento de cada peça, toma a história como o elemento aglutinante de todas as modificações da dramaturgia no século XX. Desse modo, acreditamos ser possível oferecer contribuições tanto para os estudos voltados às relações entre literatura e história quanto para o conhecimento desse sistema específico que é a dramaturgia mexicana.

A constatação de que o mundo se organizaria a partir dos acontecimentos que marcaram historicamente a coletividade levou Octavio Paz (1994) a afirmar que o mexicano não é uma essência, mas uma história. Essa marca da mexicanidade teria se materializado nas mais diferentes esferas sociais e culturais. $\mathrm{Na}$ esteira do poeta, identificamos que nas demais formas literárias, a força expressiva que autores como Mariano Azuela, Jorge Ibargüengoitia, Rosario Castellanos, Elena Garro, Carlos Fuentes etc. alcançaram nacional e internacionalmente resulta, entre outros motivos, do mergulho na história e na historiografia.

O teatro, sendo uma manifestação artística com poder de assimilar e mostrar as nuanças de um povo em determinado momento de sua história ${ }^{16}$, aglutina em seu fazer

\footnotetext{
${ }^{15}$ Lembramos ainda o estudo de Ronald D. Burgess (1991), The New dramatists of Mexico.

${ }^{16}$ Nietzsche acreditava em um "espírito do tempo" que torna possível o nascimento e/ou a morte de um gênero dramático. Com o mesmo sentido, Touchard (1970) defendeu que em cada época os homens são tomados por angústias características das concepções de mundo predominantes. As obras teatrais conseguem captar essas angústias e projetá-las nas cenas. Mesmo um homem de teatro como Brecht (2005), que insiste na força teatral para modificar as relações sócio-históricas, reconhece, em "Teatro recreativo ou teatro didático", que a representação do épico não seria possível em qualquer lugar. Para ele, durante os anos 50, sem disposição dos espaços para o debate de seus problemas, cidades como Londres, Paris, Tóquio e Roma, ao contrário de Berlim, ainda não estavam prontas para participar da experiência do teatro épico. Em âmbito brasileiro, o ator e diretor Peixoto (1992) alerta que na vivência do teatro, como espectador ou
} 
os pontos de inflexão que conduziram à forma de organização social, política e econômica dos tempos atuais. Esse aspecto, que já assinalamos como foi percebido pelos críticos comentados anteriormente, ecoa em outras publicações. Em artigo para o dossiê sobre dramaturgia e história que a revista Paso de Gato publicou em razão da comemoração do bicentenário da Independência e do centenário da Revolução, David Eduardo Salinas retoma a ideia de que a história é para o México um território que está sempre em movimento, em constante processo de construção. Marcada por avanços e retrocessos, mas, sobretudo, por permanências e repetições, ela "se hace presente como un horizonte" de reflexões que merece ser olhado e encarado com assombro. $\mathrm{O}$ autor reafirma o jogo de esconder e revelar a mentira e a verdade, próprio do teatro, da política e do fazer histórico ${ }^{17}$. Com efeito, “abundar en esta filiación, apenas si es necesario. Quizá habría que añadir que este juego de luces, de engaño-desengaño, es el gran tema de nuestro teatro presente, donde la verdad se hace necesaria condición." (SALINAS, 2010, p.22). Por fim, poderíamos ainda citar o artigo de Timothy Compton (2004, p. 65) para quem

la historia nacional y sus figuras históricas giran constantemente en la conciencia de la mayoría de los mexicanos. [Por tanto] No debe sorprenderle a nadie el hecho de que los intelectuales mexicanos hayan tratado extensamente cuestiones relacionadas con la historia nacional y con la historia en general.

A despeito de a crítica documentar com insistência a presença das conexões entre história e o pensamento das humanidades e das artes, percebemos que por ora não se constata nem se explicita de que modo as inter-relações se vinculam às propostas de construção nacional em diferentes momentos. Dessa forma, surgem questões como estas: haveria uma motivação especial dos autores ao trabalhar a história como matéria-prima da criação dramatúrgica? Seriam apenas motivações pessoais ou escolhas que fazem parte de uma "tradição"? A recorrência aos temas históricos acentuou-se em algum momento específico? E, por fim, algo que está praticamente ausente das pesquisas: quais transformações estéticas foram encadeadas à exploração da história como fonte dos enredos? A respeito dessa última questão, ressaltamos que a preocupação crítica mais

artista, não se pode perder de vista que não existe autonomia total, pois entre a sociedade e a obra há um movimento dialético.

17 Esse jogo também foi comentado por Octavio Paz em "Máscaras mexicanas" (El laberinto de la soledad,1994). Para ele, a questão está tão presente na cultura de seu país que chega a ver El gesticulador, de Rodolfo Usigli, que trata das formas enganosas sobre as quais se erguem os heróis nacionais revolucionários, como um descendente de La verdad sospechosa, de Juan Ruiz de Alarcón, obra do século XVII. 
geral, volumosa e recorrente, tem sido reconhecer de que modo determinadas técnicas dramáticas e cênicas construídas nos centros hegemônicos (europeus e norte-americanos) "teriam influenciado" os autores nacionais. Cremos, ao contrário, que no México as mudanças tenham acontecido, em grande medida, a partir dos próprios autores nacionais pensando a história.

Para tentar responder a essas e outras questões, elaboramos a priori uma divisão da dramaturgia mexicana em quatro momentos, tomando como ponto de partida a cronologia de autores e peças. A divisão, apesar de insuficiente para dar conta do fenômeno, busca facilitar a visualização das diferentes expressões assentadas no uso da história. O período coberto por essa divisão vai de 1920 a 1995. O primeiro situa-se entre os anos imediatamente pós-revolucionários até por volta de 1938 - quando Usigli escreve El gesticulador e é realizada a última apresentação do Teatro de Orientación. Chamaremos esse momento de "experimentação e vanguarda".

$\mathrm{O}$ período se distingue pelo amplo debate entre nacionalismo e cosmopolitismo - problemática, aliás, nunca abandonada de vez até finais do século XX. Com “experimentação" designamos antes um conjunto de fatores do âmbito da produção cultural do que necessariamente a elaboração dramatúrgica, pois, no que tange às questões estéticas como o tratamento da ação, o parâmetro deve ser as manifestações herdadas do século XIX, sobretudo as da época do regime de Porfirio Díaz, ou seja, a exibição predominante dos chamados gêneros chicos, o teatro de revista ou de carpa. O que vemos, sobretudo entre 1920 e 1938, é o surgimento de grupos - sempre liderados por intelectuais e artistas que a princípio não têm contato direto com o teatro - empenhados em criar espaços para encenação a partir da tradução de dramaturgos estrangeiros.

Dentre os grupos, ganham destaque o Teatro de Ulises, os Escolares del Teatro e o Teatro de Orientación. O primeiro nasceu do desejo de Xavier Villaurrutia, Gilberto Owen, Antonieta Rivas Mercado ${ }^{18}$, Celestino Gorostiza e outros, de poder assistir a representações de cunho mais artístico, em sintonia com o que de melhor se produzia na Europa e nos Estados Unidos. A marca da labuta artística desses grupos é a autonomia diante o governo, pois, embora houvesse propostas governamentais, não existia ainda um sistema articulado de incentivo à produção cultural em geral e ao teatro, em particular.

\footnotetext{
${ }^{18}$ Sobre essa importante agitadora cultural e incentivadora das artes mexicanas, sugerimos a leitura da tese defendida por Romilda Costa Motta em 2015 pelo programa de História Social da FFLCH - USP, sob orientação da Dra. Maria Lígia Coelho Prado.
} 
Por outro lado, os Escolares del Teatro foi criado com um caráter profissional, contando, com aporte financeiro estatal. O local para ensaios e representação localizavase nas dependências da Secretaria de Educação Pública. Sob a direção de Julio Bracho e, institucionalmente, liderado por Celestino Gorostiza, esse grupo representa uma espécie de preparação para o Teatro de Orientación, que também contaria com forte apoio governamental.

Durante os anos em que surgiram esses grupos, outros semelhantes foram se formando, entre os quais o Trabajadores del Teatro, que resultava da dissidência de Julio Bracho com os Escolares. Podem ser mencionados, ainda, o Teatro Mexicano del Murciélago, o Teatro Sintético Mexicano, o Teatro de la Universidad, o Teatro de Ahora, o Teatro Mexicano de Masas e o Teatro de Medianoche. Em síntese, todos eles buscavam, com maior ou menor intensidade, encontrar uma expressão dramática que contribuísse para a construção do México pós-revolucionário (como pode se apreciar pelos nomes de alguns deles). Os grupos e dramaturgos de postura engajada apostavam na representação de peças escritas por autores nacionais. Em contrapartida, o incentivo ao desenvolvimento artístico vinha da tradução de autores estrangeiros. ${ }^{19}$

Nesse momento, apesar de existirem diversos intelectuais preocupados em fomentar o teatro por meio da criação de grupos, espaços para encenação e formas de financiamento público, não havia preocupação com a história enquanto tema. Questões contemporâneas ofereciam o tom das peças, tais como em Pánuco 137, de Mauricio Magdaleno, acerca da exploração petrolífera. Além disso, a perspectiva de que se vivia, nos inícios dos 40, um renascimento nas artes, impulsionou o resgate de temas clássicos. Tal aspecto se visualiza sobremaneira em Ifigenia cruel, de Alfonso Reyes.

Com o desenvolvimento econômico e social dos anos 40, novas expressões ganhavam corpo. Podemos denominar esse segundo período de "formação do sistema teatral", que compreende os últimos anos da década de 1930 a 1947 — redação e montagem de El gesticulador, respectivamente.

Nesse segundo período permanece a inquietação por instituir estruturas de financiamento e organização teatrais (tais como a criação de espaços exclusivos para a

\footnotetext{
${ }^{19}$ Há uma extensa bibliografia sobre os grupos de vanguarda no México. Registramos dois cujas posturas são complementares: o de Luis Mario Schneider (1995), Fragua y gesta del teatro experimental en México, e o de Alejandro Ortiz Bullé-Goyri (2005), Teatro y vanguardia en el México posrevolucionario (19201940). Schneider apresenta o Teatro de Ulises, os Escolares del Teatro e o Teatro de Orientación a partir de muitas resenhas e críticas surgidas no momento em que as peças eram encenadas, ao passo que Ortiz Bullé-Goyri faz uma análise mais minuciosa do contexto, inserindo outros grupos e matizando a participação de cada um deles na formação da vanguarda teatral.
} 
representação e formação de profissionais) e o debate em torno dos problemas nacionais. As principais marcas dessa labuta pela melhora do sistema veem-se na construção, em 1946, do Instituto de Bellas Artes (INBA) e da Escola de Arte Teatral, hierarquicamente subordinada ao primeiro. A história passa a ser tema recorrente do grande nome desse período, Rodolfo Usigli, que vai fixar o conceito de anti-história, sob o qual agrupa procedimentos de revisão da historiografia. Assim como no período anterior, a concepção dramática predominante é aristotélica, isto é, se pauta pela unidade de ação, de tempo e de espaço. Outra marca é a preponderância do dramaturgo perante ao diretor.

O terceiro recorte temporal que compreende os anos de 1947 a 1968, denominaremos de momento pós-usigliano ${ }^{20}$, pois nele se destacam autores que aprenderam a arte da dramaturgia com Rodolfo Usigli. Em 1968, o teatro de tendência épica se integra ao sistema com a montagem de Pueblo rechazado. Neste momento, se consolidavam os projetos iniciados entre 1920 e 1947. Os dramaturgos mais representativos, Emilio Carballido, Hugo Argüelles, Luisa Josefina Hernández e Jorge Ibargüengoitia, estavam marcados essencialmente por dois aspectos. Todos tinham sido discípulos de Usigli na Faculdade de Filosofia e Letras da UNAM e, mais tarde, se dedicaram à formação de novos dramaturgos, seja pela continuidade das aulas na Universidade, no caso de Josefina Hernández, seja pela criação de oficinas próprias de escritura. Sobre as oficinas, Vicente Leñero que elas, "cómo método práctico para la formación de literatos, fue implementado orgánicamente en nuestro país por el Centro Mexicano de Escritores y llevado a su culminación por Juan José Arreola en la década de los cincuenta." (1996, p. 11). Ao mesmo tempo, nesse período acentuava-se o debate entre teatro de autor e teatro de diretor. ${ }^{21}$

\footnotetext{
${ }^{20}$ Armando Pereira (1997) denominou a geração intelectual que agitou a vida cultural do DF entre 1950 e 1968 de "Generación del Medio Siglo", nomenclatura já cristalizada. Sabemos que estamos bastante expostos a críticas ao negar o uso corrente, mas vamos evitá-la porque ela abarca amplos estratos culturais e nossa intenção é apenas o teatro. Estamos cientes ainda de que ao usar o termo "pós-usigli" corremos o risco de parecer uma tentativa de minimizar a força de autores como Emilio Carballido e Jorge Ibargüengoitia - apesar de todas as divergências pessoais e estéticas com o mestre - e Elena Garro e Luisa Josefina Hernández -, mesmo que todos eles tenham conquistado autonomia e independência a ponto de hoje suas obras clamarem por estudos mais consistentes. Nem de longe é essa nossa intenção. Nosso propósito é meramente indicar a permanência da concepção usigliana, segundo a qual a história é vista como algo a ser representado no palco, desde que atendidas a "verdade dramática", isto é, a permanência de unidades de espaço, tempo e, principalmente, ação.

${ }^{21}$ Em um ensaio de tom bastante autobiográfico, Sabina Berman conta um episódio que deixa transparecer as diferenças entre autores e diretores durante esse período (e o seguinte). Em meados dos anos 70, Abraham Oceransky, importante diretor, queria que ela conhecesse Hugo Argüelles a fim de aperfeiçoar sua escrita. Para Oceransky, Argüelles era o dramaturgo com quem mais se poderia aprender naquele momento. Mas o próprio diretor tinha hesitado um pouco, porque cerca de 15 anos antes (portanto, no fim dos anos $50 \mathrm{e}$ início do sessenta) ele recebera do dramaturgo uma peça, Concierto para guillotina y cuarenta cabezas que "Abraham la había dirigido con el espíritu de los directores de los años sesenta, es decir desacatando las
} 
Por fim, a última etapa, que vai de 1968 a 1995, está fundamentado pela já consolidada nomenclatura de Nova Dramaturgia (BURGESS, 1991 e PARTIDA TAYZAN, 2002a). Nesse momento, em obras como Entre Villa y una mujer desnuda, de Sabina Berman, e La noche de Hernán Cortés, de Leñero, a história se manifesta como denegação. A peculiaridade consiste em acentuar o interesse não por um ou outro evento, mas pelo imaginário, os estereótipos, os problemas e temas que persistem nas décadas e séculos. Dentre as razões que explicam por que os autores desse período promoveram mudanças — às vezes radicais — nas estruturas dramáticas, está a dificuldade de encontrar apoio governamental para as montagens. Conhecida também como "generación del desconcierto" ou "generación de la década perdida" (BURGESS, 1985) ${ }^{22}$, não aproveitou a época áurea dos auxílios e subvenções estatais que tinham proliferado no auge da economia pós-revolucionária.

Antes de encerrar este tópico, convém insistir em que a divisão proposta é didática e tende a facilitar a visualização da paisagem. O deslinde das etapas serve como ponto de partida, pois esse procedimento se ajusta mais à elaboração das marcas que diferenciam um período do outro. Porém, como nosso propósito é traçar um histórico tendo como base a problemática da relação entre literatura e história, não podemos falar em rupturas. Um dos fatores responsáveis pela persistência da continuidade em lugar da ruptura geracional foi, como apontamos, a consolidação do sistema de oficinas, que criou uma forma peculiar de absorver a tradição. Isso, por outro lado, não autoriza dizer que exista um apego ou uma continuação imitativa dos autores já consagrados. Por conseguinte, o termo que melhor pode definir a maneira como se organizou o sistema teatral mexicano é aglutinação, entendido como uma união em que as partes acopladas, sem perder suas características, projetam um novo significado.

Estabelecidas as linhas gerais que demarcam os pontos de inflexão nas formas de conceber o teatro em termos sistêmico-culturais e estéticos, objetivamos, em momento

acotaciones del autor, tomando el texto como un pretexto para una obra caprichosamente personal." (Berman, 1994, p. 601).

Acontece que na estreia, Argüelles não tinha gostado nem um pouco da montagem; o público também havia apresentado pouco entusiasmo. Na ocasião, Abraham tinha se justificado dizendo que era "un creador de imágenes sublimes y no un ilustrador de creatividades ajenas. Por lo demás [...] en el teatro el único tirano posible es el director, el dramaturgo es una pieza más del engranaje de la máquina que el director hace funcionar a su voluntad" (p. 601-602).

${ }^{22} \mathrm{O}$ termo deve ser visto com ressalvas no que tange à classificação geracional. A “década perdida" é uma categoria da história econômica para designar a grave crise de 1982 a 1989 que obrigou o México a abrir definitivamente o capital a empresas estrangeiras e promover uma política neoliberal a partir dos anos 90. Optamos por mantê-lo porque, as considerações sobre a crise econômica serão relevantes na terceira etapa de nosso estudo, da qual Sabina Berman é a autora mais representativa. 
oportuno deste trabalho, verificar se há e quais são as especificidades da elaboração artística da história. Nossa hipótese é que as mudanças ocorridas na concepção estética e na ação dramática estão diretamente relacionadas com a forma de se encarar a historiografia e a história. Para investigar a validade dessa conjectura, selecionamos autores e obras de grande destaque. Enxergamos em Rodolfo Usigli o criador de um projeto que se consolida em meados dos anos sessenta, quando a obra de Vicente Leñero, incorporando as contribuições do teatro documental e brechtiano e vendo sinais de desgaste na produção anterior de seu país, abre caminho para a imersão nos problemas "históricos" mais urgentes, que serão amplamente explorados pelos novos dramaturgos. Nesse jogo dialético entre a vontade de inovar e a permanência do recurso histórico e factual, a obra de Sabina Berman se destaca porque incorpora as lições do tratamento documental de Leñero e abre, a partir da reflexão feminista, os caminhos de um teatro preocupado com aqueles que estão excluídos dos centros do pensamento e do poder. Em nossa seleção, não excluiremos a presença de outros dramaturgos de maneira que possamos, pelo confronto com aqueles sobre cujas obras nos debruçamos com cuidado, enfatizar a importância da recorrência aos eventos passados como elemento aglutinante.

\subsection{Tessitura nacionalista da história}

Se a preocupação com a história é um componente peculiar na cultura mexicana, a ponto de intérpretes como Octavio Paz (1994) atribuírem a ela relevância ímpar na constituição dos processos identitários ("El mexicano no es una esencia, es una historia"), a consolidação do sistema teatral correu em paralelo com esses debates e tornase imprescindível pensar a categoria conceitual do nacionalismo para expandir a percepção de como esses dois aspectos caminharam juntos.

De fato, em artigo sobre os "Aspectos formales de la escritura dramática mexicana", Armando Partida Tayzan (1997) mostra que nos anos 60 emerge a reescrita de obras clássicas, tanto do teatro espanhol quanto do europeu em geral. O crítico percebe as marcas de uma escrita pós-moderna, caracterizada pela paródia, mas defende que, naquele momento, quando ainda não havia clareza sobre as expressões que se sedimentariam nas duas últimas décadas do século XX,

La línea directa a una dramaturgia posmoderna la encontramos en la negación ideológica de la comprensión de la historia nacional, como manifestación del rechazo por parte de una generación a la que sólo le 
tocó la cruda de la borrachera del auge del petróleo, del "milagro mexicano", de una supuesta entrada a la modernidad, al haberse entonces considerado al país como perteneciente a los del Primer Mundo. (PARTIDA TAYZAN, 1997, p. 93 - aspas do autor).

Mais uma vez, a história apareceria na configuração da dramaturgia, mesmo que por antítese. A ideia de necessidade de "comprensión de la historia nacional" tinha estado presente nas gerações anteriores, embora agora se manifestasse pelo avesso, pela sua "negación ideológica". A diferença consiste em que,

Si en el drama histórico mexicano de Usigli a Leñero, alentaba la reconsideración de nuestro pasado cercano y remoto, como una forma de hacernos conscientes de nuestra propia historia, para fundamentar nuestro nacionalismo, en la obra de Jaime Chabaud (1960), nos encontramos que ésta sólo ha sido una historia de traiciones y de negaciones de la propia nacionalidad. (TAYZAN, 1997, p. 93$).{ }^{23}$

O nacionalismo, não sendo um conceito absoluto — pelo contrário, vê-se que ele tomou diferentes conotações e sofreu várias modalizações ao longo do século XX, não apenas no México, mas em cada lugar onde se recorreu a ele para justificar uma ação ou a exaltação de um herói —, foi absorvido de modo distinto pelos dramaturgos em cada etapa. Para aqueles que integravam o processo de formação do sistema, com Rodolfo Usigli na proa, que haviam recém-saído da Revolução e que acreditavam na inexistência de uma estrutura teatral consolidada, o nacionalismo significava a valorização dos elementos próprios e autóctones, enquanto para geração de Chabaud e de Sabina Berman, a exaltação desses elementos é condenável se eles não vêm acompanhados de uma reflexão crítica.

Portanto, antes de mostrarmos detalhadamente como a história foi articulada com maior ou menor ênfase na valorização, na exaltação, e mesmo na "negação" da nacionalidade, pensamos ser importante analisar as variadas formas de manifestação e de conceituação do sentimento de pertença a uma unidade coletiva nacional, em diferentes

\footnotetext{
${ }^{23}$ Nesse texto, Partida Tayzan toca no tema das mudanças promovidas pela sucessão de gerações. Sua análise visa a apontar as diferenças entre umas e outras. Ele detecta, destacando autores contemporâneos considerados pós-modernos (Jaime Chabaud ilustra a argumentação do crítico), que a negação da nacionalidade marca o fazer artístico do ponto de vista temático. Ponderamos que a consciência de que a história seja feita de traições e negações da própria nacionalidade é um tema complexo que merece aprofundamento, porque, entre outros problemas, Usigli já apresentava essa perspectiva, mas com tratamento diferente dos recursos cênicos, da ação, enfim, de toda concepção de mise-en-scène. O que absorvemos de mais proeminente dessas considerações do crítico teatral e pesquisador das artes cênicas é o reforço da possibilidade de encarar a hipótese de nosso trabalho, isto é, que a constante recorrência às relações da literatura dramática com a história dá uma característica singular a esse sistema literário. Ademais, ao se referir a Rodolfo Usigli Armando Partido traz à baila a possibilidade de confirmar que a origem desse fenômeno se enraíza no pensamento desse dramaturgo.
} 
momentos da cena teatral mexicana. A questão crucial é: quais elementos constituintes de um povo, comunidade ou Estado contribuem para assentar as bases de um pensamento nacionalista? ${ }^{24}$

Como a reflexão teórico-conceitual sobre o nacionalismo é vasta e profícua, trazemos primeiramente discussões que extrapolam o âmbito latino-americano para, em seguida, recuperarmos de autores que estudaram as manifestações desse fenômeno no México os principais pontos da problemática.

Convocamos inicialmente as ideias de Ernest Gellner. Considera-se que seu trabalho, Nações e Nacionalismos (1983/1993), seja um dos primeiros estudos a sistematizar os processos em que os povos apresentam ideias e sentimentos de valorização e exaltação nacionais. Para Gellner, a importância maior do nacionalismo é promover a unidade política de um povo. Ele, por outro lado, rejeita a crença de que se encontre na história a origem perdida de uma nação, isto é, para ele, presumir que existe uma Idade de Ouro nacional é um mito. Com isso, ele coloca a nu a tão usada estratégia argumentativa de inúmeros governos, mormente autoritários, de buscar legitimidade através do passado remoto.

Desses postulados partem Eric J. Hobsbawm (1991/2004) e Benedict Anderson (1993/2008). ${ }^{25}$ Em Nações e nacionalismos desde 1780, o primeiro traça um percurso histórico do conceito. Segundo ele, na formação do nacionalismo existiria um esforço de construção, de invenção, de engenharia social. Das últimas décadas do século XVIII até as cinco primeiras do seguinte, são mostradas, por meio de registros em dicionários e enciclopédias, as mudanças nos pilares que sustentavam um "princípio de nacionalidade". Até o fim das revoluções, por volta de 1860, três critérios eram suficientes para se reconhecer uma nação. O primeiro era "sua associação histórica com um Estado existente ou com um Estado de passado recente e razoavelmente durável”. O segundo "era dado pela existência de uma elite cultural longamente estabelecida, que possuísse um vernáculo administrativo e literário escrito". Por último, "uma provada

\footnotetext{
${ }^{24} \mathrm{O}$ nacionalismo é uma categoria de análise histórico-social bastante significativa para a literatura dos países latino-americanos, porque muitos romances, crônicas, peças e poemas foram criados com a função ética de auxiliar na construção da identidade nacional em determinado momento histórico. Nas palavras de Leyla Perrone-Moisés (2007), na América Latina, o parentesco / a filiação linguística, a eliminação de boa parte das culturas autóctones, a formação europeia, todos esses motivos ofereceram aos escritores as bases para assumirem "a missão de criar, ao mesmo tempo, uma pátria e uma literatura própria" (p. 32).

${ }^{25}$ Não obstante as correntes teóricas desses autores sejam diferentes, nosso interesse não é discutir epistemologicamente o termo, mas absorver os princípios de cada um na medida em que apresentam fatos e processos que, com maior ou menor intensidade, são encontrados ao longo da história mexicana. Esses aportes teóricos oferecem clareza sobre quais elementos podem ser tomados para se pensar, nas artes, a postura nacionalista.
} 
capacidade para conquista" encerrava os critérios de reconhecimento e legitimidade nacional. Nesse sentido, havia pouca dificuldade de se reconhecer, por exemplo, Inglaterra, Itália e Espanha como nações.

No século XIX ocorrem mudanças, porquanto às questões tradicionais de que a existência comum de uma etnia, uma língua, um território e uma história pudessem sustentar a nação no plano ideológico, paulatinamente foi acrescentado o fator econômico, sobretudo quando emergiu a teoria liberal do economista Adam Smith. Hobsbawm pergunta-se, então, sobre a importância da burguesia liberal e dos intelectuais, considerados atores que "imprimiram mais firmemente sua marca na Europa" (2004, p. 35) daquele período e quando o princípio de nacionalidade mudou o mapa do continente. Como naquele momento as relações econômicas entre países já era uma realidade, a explicação de Hobsbawm (p. 37) vai no sentido de esclarecer que os

teóricos do sistema mundial tentaram mostrar que o capitalismo foi criado como um sistema global em um continente, e não em outro lugar, precisamente por causa do pluralismo político da Europa, o qual não constituía nem fazia parte de um único "império mundial". (aspas do autor).

Essas relações ocorreriam na medida em que a nação fosse grande, forte e unida o suficiente para o desenvolvimento autônomo. Outra concepção que se manifesta em paralelo é a ideia de que uma nação deveria ser aquela que estava livre do provincialismo das pequenas cidades. Nesse contexto, as teorias previam que fatores como as línguas nacionais tenderiam a desaparecer em razão da necessidade de se falar uma língua de dominação. As expressões linguísticas de pequenas nações seriam como peça de mostruário em um antiquário. Portanto, com a emergência da teoria liberal econômica, etnicidade, língua e história comuns não eram mais critérios capazes de determinar a formação das nações. (HOBSBAWM, 2004).

Uma última mudança, diretamente vinculada aos debates econômicos, merece ser destacada. O impulso expansionista e dominador que caracterizou as nações até aquele momento passou a ser relevante enquanto expansão de mercado e crescimento econômico. A questão que se colocava, então, era como o avanço econômico estava vinculado com a possibilidade de manter a nacionalidade. Nas próprias palavras de Hobsbawm (p. 53):

do ponto de vista do liberalismo [...] a causa da "nação" estava [agora] no fato de esta representar um estágio no desenvolvimento histórico da sociedade humana; e a questão do estabelecimento de um Estado-nação 
específico dependia de este mostrar-se adequado ao progresso ou à evolução histórica avançada. (aspas do autor)

O raciocínio do autor de A era das Revoluções carrega marcas profundas de sua visão de mundo. Por se dedicar ao caso de países hegemônicos europeus, ele deixa de observar as peculiaridades dos países americanos, especialmente no que tange à abordagem do tempo. O tempo da história, isto é, a perspectiva da qual se enxerga o passado ou o futuro, tem, não raro, o intuito de contribuir para a legitimação do Estado ou para reforçar a necessidade de sua criação. Segundo Gellner, as expressões nacionalistas ocorrem quando o Estado já se formou:

A existência de unidades politicamente centralizadas, bem como de um clima político-moral em que tais unidades centralizadas são aceites e consideradas normativas, constitui uma condição necessária do nacionalismo, embora certamente insuficiente. (GELLNER, 1993, p. $16)$.

O fenômeno que se inicia com a formação do Estado e chega ao desenvolvimento das expressões nacionalistas também passaria por três fases: a préagrária, a agrária e a industrial. Da longa explanação feita for Gellner (a qual em alguns momentos ganha muito em imaginação), queremos reter um elemento da passagem da fase agrária para a industrial. Trata-se da educação, do domínio da escrita e da expansão do conhecimento a um número maior de pessoas. Segundo ele, esse período (que não se restringe a datas específicas, mas a etapas pelas quais as nações passariam) caracterizase pela existência de uma elite letrada que não mais detém o monopólio do "letramento" do sistema social. É no pressuposto de que a "instrução não constitui uma especialização, mas sim uma pré-condição de todas as especializações" que reside "o segredo do nacionalismo". (GELLNER, p. 35). Portanto, uma vez que o Estado organizado e sustentado pela educação massiva é uma das principais marcas do nacionalismo, o elemento educacional multiplicado a todos é capaz de dar sustentação ao Estado sem necessidade de recorrer à força ou ao enfrentamento com outras nações. (GELLNER, p. 59).

Ainda em função da importância da educação, decorre a compreensão de que os sentimentos nacionalistas não são "naturais". Nesse ponto, ganha relevo no debate a questão da sobrevivência das culturas em meio a sociedades altamente industrializadas e especializadas tecnicamente. Segundo ele, "na era industrial só as culturas eruditas acabam, no final, por sobreviver. As culturas populares e as pequenas tradições 
sobrevivem apenas artificialmente, mantidas por sociedades que conservam a língua e o folclore" (GELLNER, p. 173). ${ }^{26}$

Nesse ponto, Benedict Anderson (2008), em Comunidades imaginadas, prefere avançar no sentido de compreender de que maneira as transformações da cultura letrada, e não apenas no aspecto educacional, põem em movimento as expressões nacionalistas. Assim, enquanto Gellner aborda o papel da escola nesse processo, Anderson destaca também o da imprensa na "vernaculização" das nações. Ele defende que há basicamente três fatores na formação das comunidades imaginadas modernas: "uma interação mais ou menos casual, porém, explosiva, entre um modo de produção e de relações de produção (o capitalismo), uma tecnologia de comunicação (a imprensa) e a fatalidade da diversidade linguística humana", em oposição ao domínio do latim. (ANDERSON, p. 78). O que percebemos, então, é que acentuadamente em dois desses fatores (e em menor sentido no terceiro) o elemento educacional, destacado por Gellner, sedimenta as possibilidades de desenvolvimento de expressões nacionalistas.

A diferença está no fato de que Anderson não acredita que, por si só, a educação formal, aquela que se organiza e sistematiza em instituições de ensino, tenha possibilidade de promover e amalgamar pensamentos nacionalistas. Negando essa ideia a partir do caso específico das Américas, ele afirma em uma nota de rodapé: "as instituições acadêmicas foram insignificantes para os nacionalismos americanos" (ANDERSON, p. 112). Realmente, nesse primeiro nacionalismo, o do século XIX (aquele que Hobsbawn situa entre os anos de 1870 e 1914 na Europa), o mundo escolar formal e acadêmico não contribuiu sobremaneira. No entanto, é inegável que no século XX a formação dos estados modernos (ou a modernização dos Estados) passa pelas instituições de ensino e pela ampliação da educação formal ${ }^{27}$.

Direcionando agora o olhar para o México, chama atenção que os estudos acerca do nacionalismo frequentemente fixem suas raízes em momentos históricos anteriores ao da própria configuração do termo. Assim, David Brading (1991 e 1998) defende que o fenômeno começa já no século XVII, e segue até fins da década de 90 do século XX. Enrique Florescano (2003) vasculha em cronistas criollos durante a Colônia,

\footnotetext{
${ }^{26}$ As críticas a Gellner decorrem, entre outros motivos, do uso de categorias como "cultura erudita", "sociedades superiores" etc.

${ }^{27}$ José Joaquín Brunner, em "Tradicionalismo y modernidad en la cultura latinoamericana" (revista Escritos, n. 13-14, jan./dez. de 1996, p. 301-333), e Néstor García Canclini em Culturas híbridas (2001), mostram a participação dos processos educativos e dos incrementos na educação formal como fatores constituintes do processo de modernização da América Latina. Estão aqui apenas mencionados por não se voltarem especificamente ao nacionalismo.
} 
os motivos que auxiliaram a pensar a nação mexicana nos períodos de independência. Por sua vez, Peggy K. Liss (1986), optando pelo termo nacionalidade, encontra nas primeiras décadas de colonização (1521-1556) as bases que seriam desenvolvidas posteriormente pela independência. Por fim, Jacques Lafaye (1992), usando o conceito de longe dureé, procura demonstrar como os cultos à Virgem de Guadalupe e a Quetzalcóatl sustentam a nacionalidade mexicana e dão coesão ao Estado-Nação.

Esses estudos buscam na história os elementos que auxiliaram na conformação do nacionalismo. Porém, o debruçar-se sobre um momento, um tema, um fato histórico não é, por si só, uma atitude nacionalista. O nacionalismo implica um projeto comum de várias camadas e estratos sociais com vistas a uma coesão ideológica.

Não é à toa que Octavio Paz (1992) crítica no estudo de Lafaye (1992) justamente a adoçãoo metodológica de uma perspectiva linear. Isso para ele provocaria erros de interpretação, dentre os quais, acreditar que os jesuítas, Sigüenza y Góngora e soror Juana Inés de la Cruz seriam precursores do nacionalismo mexicano. Paz manteve essa mesma postura no monumental estudo sobre a monja jerônima (Sor Juana Inés de la Cruz o Las trampas de la fe, 1982/1998). Segundo ele, não obstante seja adequado dizer que a poetisa (como bem mostra Jacques Lafaye) incorpora símbolos, personagens, léxicos e estruturas sintáticas da cultura náuhatl, isso não significa por si só uma expressão nacionalista capaz de atravessar o tempo. Diferentemente de outros pesquisadores, Paz defende que ela é fruto de sua época e nela esteve situada.

Esse caso específico do discutível "nacionalismo" de soror Juana alimenta o debate sobre de que maneira os fatores como a nação, o estado, o território, a cultura e a língua ajudam a dar coesão a uma estratégia de legitimação do poder de um grupo específico. A história (e a historização desses fatores) oferece, então, condições capitais, pois por causa dela se explica e se justifica um projeto nacional compartilhado em diferentes âmbitos sociais.

Acreditamos que a compreensão do pensamento nacionalista no México precisa seguir por outra vereda que não a detecção de "elementos autóctones" em autores e pensadores em geral. O risco aqui, parece-nos, é debruçar-se sobre monumentos para encontrar elementos pitorescos, cheios de frescor, promovendo, dessa forma, um uso da história que Nietzsche (1949) chamou de antiquária. ${ }^{28}$ Se abordamos o nacionalismo

\footnotetext{
${ }^{28}$ No sentido empregado por Nietzsche (1949), o homem que sente a história como se fosse um antiquário expressa conservação e veneração por ela. Conservar e venerar significa reconhecer o valor de algo
} 
pautando-nos pela análise de filósofos, sociólogos, poetas, romancistas etc., pensamos poder compreendê-lo melhor.

Portanto, a fim de operacionalizar a intersecção das ideias nacionalistas com a formação do sistema dramatúrgico mexicano, destacaremos na análise de cada autor do nosso corpus, alguns pensadores e obras cuja reflexão impactou de maneira mais ou menos intensa as preocupações com o ser nacional. Vincularemos esses aspectos à história e aos fatores que merecem ser analisados como expressões mais significativas do nacionalismo a saber: a promoção da unidade política, o avanço econômico, a educação, a existência de uma cultura letrada e de uma elite que se estabelece com o tempo e, por último, o conflito entre expressões autóctones e a globalização.

\section{Capítulo 2 - Literatura e história; dramaturgia e teatro}

O exame do gênero dramático exige breves considerações acerca da possibilidade de se estabelecer uma separação didático-analítica do fenômeno teatral entre o texto literário e a encenação. Anatol Rosenfeld (2000) lembra que o teatro incorpora a literatura e outros elementos. A incorporação acontece no momento em que o ator se funde à personagem com vistas à representação. Por outro lado, se o teatro "não é literatura, nem veículo dela" (p. 21) — mas realiza a "atualização" daquilo que o texto contém virtualmente —, vale reconhecer a possibilidade de que, em inúmeros casos, essa "atualização" torna-se possível porque o texto conserva a essência do efeito artístico almejado com a representação. Não se trata apenas de registrar as vértebras do fenômeno, mas de plasmar na língua escrita o conflito, a ação, as intenções das personagens, enfim, tudo aquilo que deve ser mostrado em cena. Portanto, apesar de a literatura não constituir na essencialidade o teatro, "a peça teatral, considerada literatura, é um dos elementos mais importantes do teatro" (p. 35) e por isso pode ser estudada em separado.

Por se tratar de arte, as diferenças entre o literário e o teatral vão além dos aspectos que compõem e organizam as obras. O receptor também integra o jogo. Assim, a experiência estética literária se realiza completamente na palavra, enquanto que a teatral

simplesmente porque pertenceu, em algum momento, a seu passado. Nesse sentido, o horizonte desse homem apresenta-se muito estreito, pois não percebe as generalizações e tende a rejeitar tudo o que é novo. 
pressupõe a integração do indivíduo a uma coletividade. Ou, na própria assertiva de Rosenfeld (p. 21-22): "na literatura são as palavras que medeiam o mundo imaginário. No teatro são os atores / personagens (seres imaginários) que medeiam a palavra. $\mathrm{Na}$ literatura a palavra é fonte do homem (das personagens). No teatro o homem é a fonte da palavra”.

Ora, feitas essas considerações, devemos ainda lembrar que a mediação do imaginário, pela palavra somente ou pelo ator / personagem, não coloca nenhuma ordem de hierarquia - pelo menos não deveria colocar, embora haja tantas tentativas de sobrepor ora o texto ora a mise-en-scène. Antes, a reflexão sobre ela auxilia a encontrar caminhos para resolver o problema nevrálgico da relação entre literatura e história: a tensão entre verdade e ficção.

Ousaríamos situar na superficialidade de algumas leituras da Poética de Aristóteles a origem dessa dicotomia. De fato, observa-se que, ao longo dos séculos, as formas de representação literária demonstraram-se, às vezes, mais tendenciosas a aproximar a linguagem da realidade — isto é, a crença de que palavra e referente empírico possuíam correspondência direta -, outras vezes, elas foram mais propensas a reivindicar a independência da linguagem diante da realidade empírica.

A forma romanesca sofreu mais intensamente essas modificações. Desde a epopeia clássica até o romance contemporâneo a escolha pela forma e estrutura acompanhou, em muitos aspectos, os movimentos de transformação da sociedade. Já o drama, enquanto expressão literária, parece ter mantido as bases lançadas por Aristóteles por longo período. Peter Szondi (2001) percebeu essa questão em sua Teoria do drama moderno ao destacar que durante muito tempo se exigiu o cumprimento de regras para a criação dramática. Mesmo Goethe e Schiller, cujas correspondências e ensaios demonstram exacerbada preocupação com a composição, almejavam evitar que se escolhesse uma matéria épica para tragédia, conforme Aristóteles aconselhava.

As observações a respeito das mudanças da forma literária para refigurar os novos conteúdos que a dinâmica social apresenta em diferentes lugares e tempos trazem questões relevantes para nossa investigação. Questionamos, entre outros aspectos, em que se distingue a forma dramática que representa um evento histórico de outras manifestações do mesmo gênero e como são articulados os elementos composicionais de modo a causar no leitor e no espectador o efeito catártico (de acordo com o que pretendia o teatro aristotélico) ou o despertar da consciência (conforme almejava o épico)? Será que 
o adjetivo caracterizador do "drama histórico" designa apenas a escolha de um aspecto temático?

No que concerne às análises da dialética entre os gêneros e as condições histórico-sociais de que emergem e nas quais se desenvolvem, os ensinamentos de György Lukács (2011) contribuem de modo especial para o debate. Ele reflete sobre o drama em dois momentos de sua trajetória filosófico-crítica. Inicialmente, por volta de 1909, escreve "O drama moderno", ensaio ainda da juventude. Depois, na profunda reflexão de $O$ romance histórico, se estende na análise das composições teatrais com vistas a contrapô-las à forma épica. Aqui, o ponto de partida é o conflito dramático. Segundo Lukács, nele reside a característica fundamental do drama, o traço que o difere do romance. O conflito concentra "a figuração da totalidade da vida". Isso significa que ele agrupa em torno de si a riqueza da tensão entre as forças sociais que lutam para prevalecer. Em comparação com o romance, essa concentração requer do dramaturgo uma capacidade ímpar para figurar os conteúdos em uma forma artística em que os acontecimentos são apresentados num avanço progressivo, sem tempo e espaço para retardamentos ou minúcias. Por isso, se há excesso de informação, a concentração se esvai. Em síntese, para Lukács (p. 144),

o verdadeiro conflito dramático tem de conter em si toda uma cadeia de momentos capazes de produzir uma elevação ininterrupta e possibilitar uma rica sequência de altos e baixos na luta externa de potências sociais que entram em conflito.

Para conquistar esse efeito, ocupam o primeiro plano do drama as personagens que fizeram a história e modificaram os destinos de uma coletividade:

como o drama concentra no conflito os momentos decisivos de uma crise sócio-histórica, ele tem necessariamente de ser composto de tal forma que caiba ao grau de apreensibilidade do conflito a decisão sobre o agrupamento das personagens decisivas do centro até a periferia. (p. 158)

Esse traço diferenciador revela que a visão do filósofo húngaro sobre o drama se afasta do que apregoa o teatro épico. Lukács, em vários momentos, demonstra derivar sua concepção da tragédia grega. Em sua teoria a história diz respeito a fatos passados e não ao tratamento narrativo, historicizado, de um tema. Isso, porém, não significa que desconsidere o presente. Ao contrário de Peter Szondi (2001), para quem não é possível haver drama verdadeiramente histórico, já que a matéria dramática, o conteúdo, passa obrigatoriamente pelo momento presente, a visão teórico-social de Lukács evita colocar 
os eventos e as personagens históricos num patamar de antiquário ou de monumento e, ao mesmo tempo, traz a questão do efeito dramático em uma coletividade. Ele reconhece o poder do drama histórico de dar a conhecer e de atualizar o passado. O fato de não o elevar a um pedestal intocável evidencia a preocupação com a fidelidade aos registros históricos. O teórico, apropriando-se das reflexões de Lessing sobre a tragédia e seus efeitos catárticos, afirma que "para o drama, o que importa é a autenticidade histórica: a verdade histórica interna do conflito", bem como "apreender de um modo profundo e legitimamente histórico a essência histórica do próprio conflito", o qual "pode ir muito além do horizonte da época e, no entanto, conservar a necessária fidelidade histórica". (LUKÁCS, p. 188).

Por outro lado, independentemente do grau de fidelidade escolhido pelo dramaturgo, a representação do drama provoca no espectador uma vivência paradoxal, pois tem de experimentar o acontecimento passado "como algo presente e que nos projeta para o futuro". Isso significa que "o drama histórico deve expressar os traços dos homens e seus destinos de modo que eles também possam provocar compaixão em um espectador que está séculos distante desses acontecimentos" (p. 189).

Quando refletimos acerca do impacto que a dinâmica temporal da representação teatral provoca no espectador, é importante enfatizar que "espectador" designa, diferentemente de "leitor", um grupo de indivíduos situados em certo tempoespaço que participa do fenômeno da representação no mesmo momento em que ela ocorre. Lukács, que se pautava pelo modelo clássico, acreditava no efeito instantâneo e imediato sobre uma multidão. Desse modo, o drama conseguiria dar "expressão aos destinos imediatamente universais, aos destinos de povos inteiros, de classes inteiras e até de épocas inteiras" (p. 163 - itálico do autor).

"O destino de épocas inteiras". Esse é o ponto nevrálgico de sua explicação, pois o drama histórico derivaria dos grandes movimentos de inflexão da história da humanidade, tal qual teria acontecido às peças shakespearianas: "Com clareza genial e muito discernimento, Shakespeare observa [o] turbilhão de contradições que perpassou as crises mortais do feudalismo durante séculos" (p. 190).

Com essas constatações, é possível voltarmos a nosso objeto de estudo, o drama mexicano de fundo histórico. Como para Lukács os eventos diziam respeito à Europa, podemos questionar se não haveria no México também esse momento histórico de enormes contradições que possibilitou, ao mesmo tempo, a plasmação moderna da dramaturgia e do teatro e o olhar para a história. Nesse ponto, podemos somente antecipar 
que a Revolução iniciada em 1910 e todo o legado interpretativo deixado por ela contribuíram sobremaneira para a manifestação do fenômeno artístico. Talvez seja por isso que um dos autores mais significativos para esse acontecimento, Rodolfo Usigli, tenha expressado que a "verdade dramática" deve prevalecer sobre a "verdade histórica", ou seja, algo semelhante ao que afirmou Lukács sobre a fidelidade aos registros historiográficos.

Contudo, antes de adentrarmos no universo mexicano, é preciso ponderar algumas categorias teóricas balizadora de nossas reflexões.

\subsection{O "histórico" no texto ficcional}

Lukács faz suas reflexões a partir de um gênero dramático específico. No entanto, pelo que apresentamos, é possível ampliar esses pressupostos àqueles dramas cuja matéria-prima são os eventos históricos. Portanto, as questões que emergem são as seguintes: em que medida dramaturgia e historiografia se interseccionam? Quais os elementos que permitem a convergência?

Para o historiador alemão Reinhart Koselleck (1993), o diálogo da literatura e da história situa-se na matéria linguística. Em estudo sobre a semântica dos tempos históricos, ele afirma que "sin acciones lingüísticas no son posibles los acontecimientos históricos; las experiencias que se adquieren desde ellos no se podrían interpretar sin lenguaje." (p. 287).

De fato, é o material linguístico, a necessidade da expressão verbal, que faz, por exemplo, historiadores como o norte-americano Hayden White, o italiano Carlo Ginzburg e o brasileiro Júlio Pimentel, reconhecerem o significado da literatura para a historiografia e desenvolverem estudos importantes sobre e a partir dessa intersecção. Procedem assim também críticos literários que pensam a história sob a perspectiva da língua. Roland Barthes (2004, p. 170), por exemplo, debruçou-se sobre a composição formal dos textos historiográficos. Para ele, “o enunciado histórico deve prestar-se a um recorte destinado a produzir unidades de conteúdo, que se poderá classificar em seguida”. O estabelecimento das unidades discursivas é sinalizado também por Käte Hamburger (1957/1986) quando estuda a categoria do tempo — altamente significativa para os historiadores — nos romances. A crítica alemã entende que, "como assunto de uma obra histórica, Napoleão é descrito como objeto, sobre o qual algo é afirmado". Já "como 
objeto de um romance histórico, Napoleão transforma-se num Napoleão fíctício" (p. 79). A visão desses críticos literários está em consonância com a opinião de Koselleck (1993, p. 199) sobre a revisão histórica, em estudo já citado: "Si Luis XVI [...] fue asesinado o si fue ejecutado o simplemente castigado, ésa es la cuestión histórica, pero no el 'hecho' de que una guillotina de tal o cual peso separa su cabeza del tronco."

A constatação de que, para a história, o evento, o factual é um objeto de discurso e de estudo, enquanto que, para a literatura em geral ele corresponde a um elemento composicional, convoca-nos a pensar as estratégias discursivas utilizadas pelo drama para enunciar e, principalmente, mostrar a história e conquistar efeitos de sentido que digam respeito ao espectador de outras épocas. Essas estratégias, inúmeras e que mereceriam um levantamento quantitativo na literatura universal, pautam-se pela a noção de tempo que orienta a compreensão dos fatos históricos e o modo como um povo se relaciona com esse tempo ${ }^{29}$.

Do ponto de vista textual, não podemos descartar a constatação de que os procedimentos estéticos dos gêneros arquitetados sobre eventos históricos dialogam intertextualmente com a história.

A apresentação de alguns problemas textuais decorrentes do contato entre as áreas pode ser mais bem ilustrada, por exemplo, com a percepção que Käte Hamburger tem do tempo pretérito em uma obra narrativa ficcional. Segundo ela, nessa situação, diferente de um livro de história, o pretérito não conta de um tempo passado em relação ao enunciador; ele é apenas um substrato no qual procede a narração, assim como uma tela suporta a imagem em um quadro. Nesse sentido, o pretérito no texto narrativo ficcional nos lembra de que esse texto é uma ficção.

Situação diferente ocorre no teatro, em que a temporalidade sempre é vivida duplamente; a conjunção do tempo presente com a presença dos fatos marca a ação teatral. Como alerta Anne Ubersfeld (1977/2005), o tempo da representação e o da ação representada se fazem presentes no teatro. Assim, falar em um tempo no teatro é considerar que ele só pode existir do encontro dessas duas temporalidades. Em suas próprias palavras: "Essa relação depende não tanto das respectivas durações da ação

\footnotetext{
${ }^{29}$ Koselleck (1993) enfatiza que o tempo histórico, assim como uma arte ou a democracia, é também criação cultural. Sua hipótese, então, é que, por esse motivo, o tempo histórico pode ser concebido a partir da determinação da diferença entre passado e futuro, ou seja, entre experiência e expectativa. Koselleck prevê a vivência coletiva da história também como expectativa.
} 
representada e da representação, mas do modo da apresentação" (p.125). E será essa forma que determinará o conjunto da significação teatral.

A percepção de que em arte os tempos são experimentados e vivenciados de maneira complexa coloca-nos o problema da classificação dos romances e dramas que podem ou não ser nomeados de "histórico". Conforme a rígida delimitação de Seymour Menton (1993), para quem a a distância temporal entre o autor e os fatos narrados deve ser um critério ao se inserir uma obra nessa categoria. Sabemos, porém, que esse princípio não pode ser determinante nos gêneros que utilizam a história como substrato compositivo. Se admitimos que somente é histórico aquilo que, em um tempo posterior conseguimos organizar e mostrar em uma narrativa, não estaríamos negando a possibilidade de poder perceber que um acontecimento se tornou, no presente, "histórico"? Esse questionamento é pertinente sobretudo na pós-modernidade, em que as sensações de passagem do tempo são cada vez mais velozes, devido à quantidade de fatos, à simultaneidade na alimentação de informações, ao surgimento (ou a busca desenfreada pelo surgimento) de novidades da ciência, da tecnologia, dos planos econômicos e até das mudanças geopolíticas.

Avançando nessa discussão, embora tradicionalmente se tenha tomado como modelo a ideia de que para haver uma obra histórica o romancista ou dramaturgo não poderia ter vivido os fatos narrados, é mister observar que a vivência dos eventos e o papel testemunhal estão no cerne da própria historiografia. Heródoto e Tucídides, por exemplo, construíram suas histórias tomando-se como referenciais. A credibilidade de suas narrativas decorria de terem presenciado os fatos. Essa postura se modifica no século XIX, em que a ênfase do discurso se colocou no documento e não no testemunho. ${ }^{30}$

Por outro lado, no âmbito literário, a ficção habilita a recriação da realidade pela linguagem e possibilita construir um discurso histórico mesmo que o autor tenha vivenciado as ações. É o caso do romance Amalia, de 1851, escrito no exílio pelo argentino José Mármol. Por meio de uma "ficção calculada", pretendeu dar um caráter histórico à sua obra, porque assim ela seria escrita pelas gerações vindouras. ${ }^{31}$

\footnotetext{
${ }^{30}$ Lembremos as palavras de Jacques Le Goff em História e memória (1992, p. 9): “a ciência histórica se define em relação a uma realidade que não é nem construída nem observada como na matemática, nas ciências da natureza e nas ciências da vida, mas sobre a qual se 'indaga', se 'testemunha'. Tal é o significado do termo grego e da sua raiz indo-européia wid-, weid- 'ver'. Assim, a história começou como um relato, a narração daquele que pode dizer 'eu vi, senti'." (itálicos do autor).

${ }^{31}$ MÁRMOL, José. Amalia. Buenos Aires: Kapelusz, 1968, 2 V.
} 
Ainda dentro dessas discussões sobre as personagens, é importante destacar mais outro ponto dentre as seis características do Novo Romance Histórico da América Latina traçadas por Menton (1993). Na terceira delas, a da diferença no foco de representação entre esse novo tipo de romance histórico e aquele que se consolidou com Walter Scott, ele destaca que, assim como os historiadores contavam eventos de grandes vultos, resultados de grandes ações atribuídas a reis, líderes e imperadores, os romancistas escolhiam cidadãos comuns. Já no século XX, acontece, segundo ele, o inverso. ${ }^{32}$

A distância temporal do evento e a preferência pelas "micro-histórias" põem sobre a mesa o papel do tempo presente na configuração da categoria de "histórico" nos gêneros literários que pautam sua concepção pelo diálogo imediato com a historiografia. Por conseguinte, será pertinente e oportuno trazermos à baila os debates de uma vertente da historiografia chamada "história imediata".

Essa vertente integra a terceira geração dos Annales. Seu representante é o francês Jean Lacouture. No conjunto de ensaios organizados por Jacques Le Goff sob o título genérico de A História Nova (2001), Lacouture apresenta a história imediata como uma área cuja exploração oscila entre o jornalismo e a história propriamente dita e cujo componente irredutível é a proximidade "temporal da redação da obra em relação ao tema tratado" e "material do autor em relação à crise estudada". (p. 216)

Por outro lado, o historiador imediatista difere do jornalista em algumas ações e, sobretudo, nas finalidades de seu trabalho. Identificação, classificação, verificação, delimitação, exclusão, coleção e montagem configuram o mettier tanto de um quanto de outro. O jornalista, porém, está submetido ao mercado de venda de notícias. O fato está no primeiro plano, enquanto ao historiador preocupa-o a compreensão do fato dentro de uma cadeia de eventos. Nas palavras de Lacouture (p. 218), "a diferença é menos qualitativa do que quantitativa".

Essas operações não estão isentas de risco. Isso porque, na cadeia de fatos, o acontecimento que será significativo para a história pode não se consolidar. O medo do risco, no entanto, não deve ser preponderante, pois o que está em jogo é um “primeiro esboço, [uma] primeira apresentação, [uma] incomparável coleção de documentos perecíveis — os gestos dos vivos, a voz humana, as cores e os odores de uma multidão e

\footnotetext{
${ }^{32}$ Lukács (2011) trabalha com a categoria do indivíduo histórico-social. Nas obras de Walter Scott, os grandes vultos históricos estão como pano de fundo dos acontecimentos; pessoas "desconhecidas", ou seja, personagens fictícios, construídos com maestria ocupam o primeiro plano. Nessas personagens se sedimentam as ideias, filosofias, tensões, enfim, todo um mosaico da época representada.
} 
de um povo no trabalho e no combate - a partir do qual as outras operações históricas se desenvolvem em profundidade" (LACOUTURE, p. 222 - sublinhado do autor).

Esses princípios da história imediata se coaduam, no teatro, ao dos dramas documentais, eles também composições interessadas em mostrar os fatos históricos do presente. A posição do "historiador", que vemos na raiz da historiografia com Tucídides, de dar forma narrativa aos eventos do presente constitui, nesses dramaturgos, o fazer literário em diálogo com a história.

A problemática da distância temporal entre o escritor e a ambientação temporal do enredo pode ser relacionada ao conceito de "realismo formal" de Ian Watt (2007), pois para ele, dentre as inovações de Defoe, Richardson e Fielding, está o fato de não extraírem seus enredos de histórias já consagradas, tais como a mitologia, a História, as lendas. O presente da sociedade moderna é a matéria-prima, apoiado em gêneros que se popularizaram em um contexto de modernização das relações humanas e das formas de acesso à leitura, com a imprensa à frente. Ele cita o caso do almanaque "esse símbolo da difusão de uma noção objetiva do tempo pela imprensa escrita" (WATT, 2007, p. 25), no romance Tom Jones, de Henry Fielding.

O imediatismo da imprensa como forma de se fazer história se descortina também na esfera da literatura e da crítica latino-americana com Julio Ramos (2008). O crítico argentino faz notar que a disposição das notícias em um jornal associada a um modo de vida marcado pela velocidade contribuiu para a ascenção da crônica como um gênero voltado à análise e às histórias do cotidiano.

Portanto, o que percebemos com as reflexões do crítico inglês e do argentino é que com gêneros textuais voltados para a (pretensão de) representação fiel da realidade dispara a criação de estratégias de ficção. Esse procedimento caracteriza em boa medida a modernidade nos sistemas literários, pois, como nos lembra Watt (2007), a partir das transformações da revolução industrial no século XVIII - e, acrescentaríamos, do avanço científico do século XIX — a escrita literária não se pauta mais por modelos, mas sim pelo gênio indivual, pela expectativa de originalidade.

A partir da apresentação de algumas questões fundamentais nos estudos que buscam a intersecção entre literatura e história e da percepção de que no texto de ficção o tempo é vivido em planos diferentes e simultâneos, um último ponto precisa ser discutido: o conceito de "histórico". Uma vez que esse termo é o qualificador dos gêneros (drama ou romance), deve ser explicitado a fim de tornar mais claro seu significado dentro desta pesquisa. 
A conversação cotidiana, despreocupada, utiliza expressões como "foi um jogo histórico" ou "isso vai entrar para a história" para designar acontecimentos particulares, únicos que, de alguma forma, são importantes para uma coletividade. Ao mesmo tempo, não consideramos históricos fatos que são rotineiros. Essas expressões espelham a opinião de Paul Veyne (1995, p. 38) sobre a especificidade do histórico:

A história interessa-se por acontecimentos individualizados dos quais
nenhum apresenta dupla função, mas não é sua própria individualidade
que a interessa, ela procura compreendê-lo, isto é, encontra neles uma
espécie de generalidade, ou mais precisamente, de especificidade.

Sabemos hoje que muito da existência de um evento histórico está atrelado à força da construção discursiva. Isso significa que devemos perceber, nos gêneros literários que dialogam diretamente com a história, que quase sempre a interação se estabelece com a narrativa histórica que já foi formulada na escrita pela historiografia. De acordo com o que sinalizamos acima, isso implica um procedimento intertextual. Como a intertextualidade pressupõe recorrer ou reportar-se a um discurso anterior, o "histórico" pode assumir diversas características nos textos ficcionais. Uma delas é o que vamos chamar de consagração do acontecimento. O fato consagrado pela historiografia decorre da aceitação pelos integrantes do próprio campo intelectual. Essa consagração consegue, porém, extrapolá-lo e atinge o domínio de outras áreas das ciências humanas, inclusive das artes como a literatura e o teatro. E, por fim, passa a constituir o imaginário de um grupo social. O romancista ou dramaturgo, então, interage na linguagem com todos esses níveis, com diferentes intensidades, de acordo com seu projeto estético.

Em suma, consideramos que um fato é histórico quando existem registros que servirão de vestígios de um acontecimento em determinado tempo. Outra marca consiste em atingir grupos, minorias ou uma nação, isto é, há necessidade de que o fato marque uma comunidade minimamente coesa em termos linguísticos, políticos, religiosos ou culturais. ${ }^{33}$

\footnotetext{
${ }^{33}$ Da maneira como o entendemos, o histórico possui materialidade linguístico-discursiva e está ligado mais ao que se produz acerca de um evento do que aos registros em si, produzidos no calor da hora em que ocorrem os eventos. Por esse motivo, ao substantivar a função adjetiva dos gêneros literários que dialogam intencionalmente com a história, propositalmente evitamos o conceito de memória coletiva desenvolvido por Maurice Halbwachs (1950/2006), uma vez que, para ele, "a história só começa no ponto em que termina a tradição, momento em que se apaga ou se decompõe a memória social", cuja característica seria a junção das lembranças individuais de modo a formar um mosaico do todo.
} 
Todas as questões levantadas de maneira panorâmica nas linhas precedentes darão a batuta para aprofundar nas categorias fundamentais de análise dos autores e obras selecionadas.

\subsection{Os gêneros de extração histórica e a preocupação com a veracidade}

O foco das discussões anteriores recaiu nos aspectos filosóficos da narrativa histórica e, em menor medida, da relação entre história e literatura. Ao examinar, ainda que brevemente, as mudanças epistemológicas da historiografia e, com maior destaque, o estatuto ficcional do texto literário que se baseia em temas retirados da historiografia, era nosso interesse ponderar os mecanismos de representação e abrir espaço para pensar que, no intuito de questionar o "verdadeiro" por meio do ficcional, o literário recebe novas estratégias de ficcionalidade e procedimentos estéticos.

O subtítulo acima se baseia na expressão "narrativas de extração histórica", com a qual o ex-professor da Universidade Federal Fluminense André Trouche (2006) nomeou os textos que conjugam em sua arquitetura a imaginação criativa e os eventos históricos consagrados pela historiografia. Com ela, o pesquisador brasileiro amplia as classificações e designações tradicionais de romance e drama históricos e contribuem para uma reflexão sobre o que a história pode oferecer à literatura no sentido estético. Com efeito, cabe expandir o significado da expressão para aprofundar, a seguir, o debate a partir da perspectiva de dois dramaturgos, Bertolt Brecht e Rodolfo Usigli, cujas obras se construíram amparadas pela história enquanto elemento de confronto da ficcionalidade com a realidade.

Existe certo consenso de que o romance e o drama históricos se sedimentam como gêneros a partir do Romantismo. György Lukács (2011) mostra como a prosa de Walter Scott ascendeu durante os finais do século XVIII e início do XIX. A proximidade da corrente estética e o consequente desenvolvimento desses dois gêneros são tão marcantes que se pode dizer que há equiparação entre os termos drama romântico e histórico. $^{34}$

\footnotetext{
${ }^{34}$ A aproximação dos gêneros históricos com o período romântico é também reconhecida, por exemplo, na América Latina, por Seymour Menton (La nueva novela histórica de la América Latina, 1993), no Brasil por Valéria de Marco (A perda das ilusões: o romance histórico de José de Alencar, 1993) e, na Espanha, María-Paz Yáñez (La historia: inagotable temática novelesca, 1991).
} 
Essa aproximação oferece-nos um primeiro parâmetro para pensar a emergência dos gêneros de extração histórica em uma sociedade. Conforme aponta Lukács, a Revolução Francesa foi o instrumento de consolidação do espírito burguês. No intuito de criar uma imagem reconhecível que condensasse os pensamentos do povo, a literatura incorporou acontecimentos históricos - e, poderíamos acrescentar, a historiografia à la Jules Michelet (1798-1874).

$\mathrm{Na}$ América Latina, acontece justamente o oposto. O momento de consolidação dos Estados Nacionais inspira uma forma literária capaz de representar as nações emergentes. Acontece, porém, que o período coincide com a formação do espírito científico da historiografia. A obra inicial de Leopold von Ranke, por exemplo, a História dos povos latinos e germânicos de 1494 a 1514, foi publicada em 1824. Pelo que se percebe então, a formação do campo historiográfico na Europa é contemporânea em alguns pontos com a emergência de gêneros literários que usam eventos consagrados pela história.

Trouche (2006) observa que nos tratados e manuais de estilo do século XVI, as exigências para o discurso histórico eram as mesmas para a prosa ficcional. Por outro lado, os referenciais históricos como esses devem ser ponderados quando pensamos nos mais diferentes contextos. Sabemos, por exemplo, que mito e história operavam de maneira sobreposta no imaginário do espectador do teatro grego. Mesmo no contexto das tragédias, em que se esboçava a separação entre o papel dos deuses e a razão humana, a história tem origem, digamos, mitológica (VERNANT; VIDAL-NAQUET, 2005). Outro exemplo é o do medievo, em que os romances de cavalaria em prosa, derivados das canções de gesta, procuravam o estatuto de veracidade pela inserção recorrente de personagens historiadores. Esse procedimento teria contribuído para o processo de substituição do maravilhoso pelo real.

Da passagem do mundo clássico para a modernidade, a inserção de personagens que são reconhecidamente representativas de um período histórico é um dos principais recursos utilizados tanto pelo romance quanto pelo drama. A presença de um ser "real", conhecido pelos feitos e reconhecido pelos antepassados, garante a verossimilhança de maneira mais direta do que a construção paulatina, coesa e coerente com que se organiza o enredo. Este nosso pressuposto encontra suporte nas palavras de Trouche (2006) sobre a aceitação da verdade / realidade do texto ficcional. Para ele, é a comunidade de leitores que baliza o efeito de veracidade: 
Para se confirmar a historicidade de um elemento ficcionalmente representado, era fundamental [no século XIX] a existência de um forte vínculo e de uma grande cumplicidade entre o destino deste elemento e o da comunidade de que faz parte. Isso porque os fatos e eventos representados pela narrativa de ficção deveriam sempre ser portadores de um significado social, repercutindo muito além da trajetória individual e/ou familiar dos personagens nela envolvidos. (p. 37-38).

A questão do significado social (em que se ouvem ecos de Lukács) exige que retomemos uma discussão levantada no tópico anterior, sobre o significado da historiografia e a experiência da história. A arte, no século XIX, é frequentemente invocada como meio de instrução das massas. O teatro moderno, por exemplo, ao deslocar a força do destino para o homem fez com que a catarse do teatro clássico cedesse lugar à função pedagógico-moralizadora. (VASCONCELOS, 2005). A história, por outro lado, que até o século XVIII era considerada, na expressão ciceriana, magistra vitae, passa a ser vista não mais em função de sua exemplaridade, mas sim como representação. (KOSELLECK, 1993).

Será, com efeito, a noção de representação que colocará, justamente na emergência dos princípios positivistas e cientificistas do século XIX, a discussão sobre possibilidade e a necessidade de se representar "verdadeiramente" algo. Assim, embora os romances e dramas pós-modernos tenham colocado a nu a concepção de que não é possível contar $a$ verdade histórica, mas sim apresentar pontos de vista, queremos salientar a emergência desse debate, devido à confluência do estabelecimento da história como ciência e do surgimento da estética realista na literatura. No fim do século XIX, a ciência, o pensamento positivo, a necessidade de experimentação e comprovação, estiveram presentes em todos os ramos do saber. Os romances e dramas produzidos, de maneira geral, não estiveram alheios à preocupação de uma expressividade objetiva, verdadeira, real.

A menção ao século XIX traz de volta as reflexões de Lukács (2011), pois seu modelo de texto histórico é um autor desse período, o escocês Walter Scott. Uma leitura um tanto superficial de $O$ romance histórico nos levaria a afirmar que o predomínio da forma realista sobre a romântica teria prejudicado a continuidade e a propagação do gênero. Essa afirmação está baseada no destaque que o crítico húngaro dá a Scott. Porém, não podemos descartar que o próprio Lukács reconheceu que Honoré de Balzac estava, com seu projeto da Comédia, produzindo um novo tipo de romance histórico. 
Outro aspecto que mostra como a discussão sobre a objetividade e a verdade dos gêneros de extração histórica emergiu fortemente em um contexto de predomínio da racionalidade científica pode ser demonstrado pensando-se na própria formação do romance em geral. Olhando o contexto, perceberemos que, se por um lado havia a convicção de que história e literatura basicamente diferenciavam-se pelo fato de a primeira desejar apresentar a verdade, ou pelo menos, conceber o discurso como verídico sobre o acontecimento, por outro, não há que se descartar o problema de que, na sedimentação do romance moderno, boa parte da ficcionalidade também tinha pretensões de realidade.

Roland Barthes, em ensaio de 1968, preocupava-se com o "efeito de real" provocado tanto pelo romance quanto pelo texto histórico. Comparando trechos de "Un coeur simple", conto de Flaubert, e Histoire de France, de Michelet, destaca que na organização da narrativa os autores abrem mão de analisar pormenores da descrição de ambientes ou movimentos descritivos que antecedem uma ação. Essas minúcias seriam os responsáveis pela produção desse efeito.

Consequência dessa sensação seria a verificação da nomemclatura de realismo atribuída a certo período da história literária. Segundo o texto citado de Barthes (p. 189): “entenda-se [por realismo] todo o discurso que aceita enunciações só creditadas pelo referente". O conceito também aparece na análise de Ian Watt sobre A ascensão do romance na Inglaterra. Em seu estudo sobre os romancistas Defoe, Richardson e Fieldings, no qual afirma que, embora exista uma multiplicidade de formas e maneiras de se configurar ao longo dos séculos, o romance tem um "denominador comum" que ele chama de "realismo formal" (WATT, 2007, p. 33), isto é, a assunção de uma forma de escrita com vistas à representação referencial.

Watt (1957/2007) ilustra esse procedimento enfatizando que na passagem da era clássica para a moderna surgiu, a criação em prosa inclinou-se para a representação de ações do cotidiano. Esse movimento se deu, entre outros fatores, devido à própria concepção de representação. Diferentemente do mundo clássico em que imperava a perspectiva da composição a partir de um modelo, entre os autores de fins do século XVIII na Inglaterra passa a predominar a tentativa de expor um referente mais direto, captado não da própria arte, mas da vida cotidiana. Até esse momento, a verdade era aquilo que tinha modelos universais; em oposição, a modernidade, ao deslocar a atenção para o indivíduo, desloca a noção de verdade para o individual. 
Em suma, a pretensão de realidade foi, no início da modernidade, um aspecto tanto da história quanto do romance. À medida que avançamos pelos séculos, XIX, XX e XXI, verificamos que história e literatura percorrem caminhos diferentes no que tange à veracidade. Nas ciências humanas, até mesmo entre historiadores, objetou-se a impossibilidade de a história dizer a verdade. Já o romance mergulhou na ficção e fez questão de escancarar essa sua maior prerrogativa.

Disso decorreram os processos de metalinguagem e metaficção, que foram tomados por Linda Hutcheon (1989/1991) como uma das principais características do romance de fins do século XX e início do XXI e que Seymour Menton (1993) inseriu em suas características do Novo Romance Histórico. No teatro, processo semelhante ocorreu. Isso pode ser facilmente percebido pela seleção de peças metateatrais de Manfred Schmeling (1982): quase todas dialogam em graus diferentes com a história.

Podemos agora, enfim, sintetizar os problemas debatidos neste tópico. Podemos, agora, expor duas questões cruciais no universo das relações dialógicas entre literatura e história: como reconhecer o "histórico" nos romances e dramas? Podemos dizer, mesmo depois das transformações sofridas na epistemologia da história, que o ficcional, quando mergulha em aspectos passados e documentados, almeja oferecer uma perspectiva nova, não alcançada pela historiografia? Advogamos que o "histórico" é a referenciação extraliterária de personagens, lugares e épocas e o diálogo intertextual com documentos nos quais se amalgama uma experiência que intervêm em uma comunidade a ponto de constituírem sua memória coletiva através do tempo. Dessa definição não ficam excluídos aqueles episódios que, no presente, provocam uma vivência tão intensa em uma comunidade de tal modo que serão, no futuro, rememorados. O "histórico" é, portanto, um elemento articulador e estruturador do texto literário que, por meio de um jogo intertextual, ancora-o no mundo empírico, produz o efeito da verossimilhança e oferece possibilidades de renovação de técnicas ficcionais.

As ideias anteriores deslindam os caminhos que pretendemos trilhar na eleição do corpus que nos auxiliará a perceber como a história do teatro mexicano é devedora das formas de pensar a história e a historiografia. No entanto, essa delimitação ficaria incompleta se não trouxêssemos para o debate um conceito capital do teatro: o Verfremdungseffekt (efeito de distanciamento), termo cunhado pelo dramaturgo alemão Bertold Brecht para designar o processo em que se rompe a "quarta parede", a barreira entre o palco e a plateia, a fim de despertar a consciência do espectador sobre seu momento e condição históricos. Como subjaz a esse conceito a noção de historicização, 
acreditamos ser de suma importância confrontá-lo a outro peculiar à dramaturgia mexicana, o de anti-história. Passaremos, então, no próximo tópico, a pensar especificamente no texto dramático a partir destes dois conceitos-chave: o distanciamento e a anti-história.

\subsection{Distanciamento e anti-história}

Até agora, elaboramos um arcabouço teórico (sustentado tanto pela crítica literária quanto pela historiografia e pela filosofia da história) que nos oferece direções para abordar as obras que serão objeto de análise em uma etapa posterior. Neste momento, interessa-nos avançar a outros pontos relevantes acerca da relação entre a literatura e a história no âmbito da dramaturgia e do teatro. Para tanto, vamos estabelecer paralelos entre a noção de teatro épico de Bertolt Brecht e de anti-história de Rodolfo Usigli, um dos autores que será cuidadosamente analisado neste trabalho. Acreditamos que por meio do cotejo desses conceitos conseguiremos observar com acuidade em que medida o diálogo dos dramaturgos mexicanos do século XX com a história pode ser tomado como uma categoria de análise peculiar dentro do sistema dramático-literário daquele país.

Queremos enfatizar logo de saída, porém, que o intuito não é verificar uma "influência" do conceito brechtiano no teatro de Usigli ${ }^{35}$, nem no teatro mexicano ${ }^{36}$. A questão central está no fato de que em ambos os conceitos a história é material para a ficção, sem, no entanto, restringir-se a um gênero específico como, por exemplo, o drama histórico. Teatro "épico" e "anti-histórico" são designações que se fixaram para um e outro "homem de teatro". As questões que orientam a construção deste tópico são as seguintes: promover, como queria Brecht, a historicização dos temas é o mesmo que conceber uma obra anti-histórica? Que aproximações técnicas podem existir entre o efeito

\footnotetext{
35 A não ser por uma leve menção a Erwin Piscator no relato "Una comedia shaviana: Noche de estío" (TC3, p. 303-416), Usigli não era seguidor das teorias do teatro épico. Nesse sentido, é esclarecedor o relato de Vicente Leñero em Vivir del teatro a propósito de sua primeira peça teatral montada profissionalmente, Pueblo rechazado, de 1968. Conta um diálogo com Usigli em que o já consagrado dramaturgo pergunta ao estreante se é verdade que "se pone más del lado de Brecht que de Aristóteles". À resposta afirmativa de Leñero, Usigli assim se expressa: "Yo no comparto sus teorías, pero, en fin, vamos a ver" (LEÑERO, 2012, p. 35).

${ }^{36}$ Para a presença de Brecht no teatro mexicano, ver, de Armando Partida Tayzan, "Bertold Brecht en la escena y dramaturgia mexicana" (p. 123-163) e, de Edgar Ceballos, "La influencia de Brecht en la escena mexicana en el centenario de su natalicio" (p. 29-44), ambos os artigos disponíveis na versão eletrônica da revista Temas y variaciones (2005).
} 
de distanciamento brechtiano e a anti-história usigliana? Apesar de aparente semelhança, poderia um recurso ser contrário ao outro?

A leitura dos textos reflexivos dos dois autores revela diferenças substanciais no que tange à concepção de história e, consequentemente, ao tratamento dado aos elementos compositivos. Porém, é preciso esclarecer que nenhum dos dois, como é peculiar aos grandes diretores e dramaturgos, construiu peças e pensamentos com finalidades estritamente teóricas. No geral, suas ideias, prólogos, epílogos, notas etc. compõem um material disperso e fragmentário (às vezes contraditório no caso do dramaturgo alemão). Todos, porém, oferecem um importante ponto de partida para compreender suas pretensões.

Tanto Brecht quanto Usigli são "homens de teatro" que manifestaram descontentamento pela arte dramática em seu contexto. Ambos detectaram que a forma de se produzir teatro, inclusive a de representação pelos atores, vivia uma crise. Em vários ensaios, Usigli destacava a falta de profissionalismo dos produtores e dos atores e a grande artificialidade das encenações. Já Brecht incomodava-se sobretudo com "a empatia por abandono" (BRECHT, 2005, p. 47), conforme ele expressou nas "Notas sobre a peça $A$ mãe". De fato, observando a situação dos teatros por onde circulavam, cada um encontrou um caminho diferente, mesmo que o papel da história seja predominante, em ambos, para renovar a arte dramática.

Nas "Notas" recém-mencionadas, Brecht defende que uma das principais características do épico deveria ser a renúncia às composições que refletissem condições "naturais" das coisas, ou seja, formas de organização social cristalizadas em certo tempoespaço, não raro assentadas sobre a exploração dos mais pobres pelos mais ricos. Brecht opõe-se ao teatro baseado nos princípios e regras que Aristóteles recolheu dos três grandes dramaturgos de seu tempo: Sófocles, Eurípides e Ésquilo.

Por isso, o autor alemão defendia que a organização das ações mostradas deveria ser de índole histórico-social: "a atitude que a encenação deverá assumir identifica-se com a de um cronista de costumes e a de um historiador; esta atitude, facilita-nos a sua compreensão". Com esse princípio, os acontecimentos não deverim ser apresentados de maneira patética, antes "têm de ser apresentados tão significativamente e sensacionalmente [sic] como qualquer acontecimento histórico reconhecido" (BRECHT, 2005, p. 49-50).

Rodolfo Usigli, por sua vez, expressa no "Prólogo después de la obra" escrito para Corona de luz o seguinte: "Si no se escribe un libro de historia, si se lleva un tema 
histórico al terreno del arte dramático, el primer elemento que debe regir es la imaginación, no la historia." (USIGLI, 1985, p. 70). Se a imaginação deve reger a fábula, isso não quer dizer, todavia, que haja uma outra história. Assim, o adjetivo anti-histórico

no se refiere a un simple desordenamiento de sucesos históricos o de su cronología, ni a un parti pris de marchar ciega e denodadamente contra la historia - eso sería estúpido - sino que involucra, o pretende involucrar, un examen y una proyección de los acontecimientos históricos en forma diversa de los que les conceden los historiadores en general. (USIGLI, 1985, p. 57).

Observamos que história, histórico, historiador são categorias incorporadas ao universo teórico de ambos os autores. Porém, enquanto Brecht toma a expressão do discurso historiográfico como modelo para o teatro épico, para Usigli é o tema histórico que interessa. É necessário destacar, por outro lado, que para Brecht o enredo não é de cunho nem fundo historiográfico, isto é, pautado pelo diálogo intertextual com documentos históricos; já para Usigli essa será a pedra de toque. Obviamente que a história está em inúmeras peças de Brecht. Mãe coragem, por exemplo, tem como cenário a Guerra dos Trinta Anos e na figura de Galileu se concentra toda a tensão das dicotomias sociais, religiosas e políticas do século XVI. No entanto, a finalidade é discutir o tempo histórico do momento em que a peça foi escrita, não o tempo passado em si. Nesse sentido, em várias peças, Usigli opta por colocar o material histórico e o arcabouço historiográfico de seus contemporâneos em cena, utilizando, entre outros recursos, a colagem.

As diferenças que os dois autores apresentam na maneira de pensar o histórico como substrato do texto dramático podem ter relação com o próprio modo de sentir a história em seu respectivo contexto. O "fazedor de peças" alemão fundamenta-se ${ }^{37} \mathrm{em}$ uma perspectiva materialista da história. Brecht certamente tinha conhecimento das mudanças sofridas pelo campo historiográfico de seu país, dos questionamentos que Nietzsche realizara do historicismo e do positivismo à Leopold von Ranke. Usigli, por outro lado, via não só a história, mas também o historiador, como uma figura carregada de preconceitos. Para ele, os historiadores eram "árboles que impiden ver el bosque - la historia" (USIGLI, 1985, p.71) 38 $^{38}$

\footnotetext{
${ }^{37}$ Usamos o termo "fundamentar-se" meio a contragosto. A fortuna crítica de Bertolt Brecht destaca, com bastante ênfase, que o dramaturgo nunca teve ideias prontas e rígidas ao longo de toda sua produção.

${ }^{38}$ Mais adiante discutiremos a importância do historiador nos planos estéticos de Usigli. Por enquanto, queremos apenas destacar que o tema é espinhoso e não é particular desse dramaturgo. Durante o século XIX, mais especificamente no governo de Porfirio Díaz, os historiadores, sob a designação geral de "científicos", ajudaram a construir uma ideia da história que, depois, foi duramente criticada. Mesmo na Revolução, desde o "Plan de Luís Potosí", se faz menção à necessidade de contestar as atividades desse grupo de intelectuais.
} 
A consequência dessas diferentes concepções de história é o aprofundamento do problema dessas obras com a perspectiva aristotélica. Como dissemos, o dramaturgo alemão rompeu com a questão da unidade tempo-espaço-ação e o efeito catártico. Já para Usigli as unidades são um princípio de composição, apesar de em várias obras ter explorado a multiplicidade de tempos. Em Brecht, as cenas, inclusive aquelas que mostram o próprio contexto extradiegético, devem ser representadas como se fossem fatos históricos, pois assim evitariam a "aclimatação emocional do espectador" (BRECHT, 2005, p. 143). Já os efeitos buscados por Usigli não chegam a esse grau de ruptura estética. ${ }^{39}$ Nas mais de 500 páginas de prólogos, notas, epílogos e análises do terceiro volume de seu Teatro completo (1979), a maioria das reflexões de Usigli está voltada para problemas imediatos de seu país. Textos como "El presidente y el ideal", escrito em 1935, sobre peça homônima, e "Epílogo sobre la hipocresía del mexicano”, de 1938, redigido antes mesmo de terminar El gesticulador, demonstram um autor profundamente envolvido com problemas de seu país e de seu tempo. Isso faz com que a maior parte das análises contemple mais aspectos culturais do que estéticos.

No plano das elaborações cênicas, entretanto, as obras lançam mão de recursos diferentes. Para Brecht, cantos, cartazes, coro são algumas estratégias com que promove o distanciamento entre o tempo do evento histórico representado e da representação; entre o universo da personagem e o do ator; entre o palco e a plateia. A quebra do fluxo narrativo pelo direcionamento da fala do ator para a planteia ou a inserção de episódios autorreferenciais também são formas de historicizar que podem, inclusive, ser consideradas metateatrais.

Em Rodolfo Usigli, a exploração dos artifícios teatrais com vistas a dialogar com a história é menos ousado e se mostra em um espaço textual mais restrito, o das didascálias. Como exemplo, tomemos a peça Corona de sombra. A peculiaridade ali está na justaposição das apreciações e intervenções do autor às informações históricas. Na apresentação do rei Carlos V, por exemplo, observemos como à genealogia do soberano seguem qualificações de sua personalidade:

\footnotetext{
${ }^{39}$ Diversos estudos afirmam que a obra de Rodolfo Usigli estabelece as bases do moderno teatro mexicano. Ao mesmo tempo, reconhecem que o dramaturgo não promoveu mudanças radicais, no sentido de romper valores estéticos antigos. Como afirma Osvaldo Pelletieri (1995, p. 628), Usigli, junto com Xavier Villaurrutia e Celestino Gorostiza "no cuestionan ni pretenden destruir la institución teatral, sino todo lo contrario." Mais adiante, quando adentrarmos no núcleo analítico de nosso trabalho, teremos oportunidade de matizar a opinião do crítico argentino, demonstrando com que sentido se pode dizer que Usigli preferiu construir a destruir a instituição teatral.
} 
Carlos V de Alemania y I de España viene vestido con un traje pardo de viaje y se asemeja mucho a sus mejores retratos. Es ya el padre de la cristiandad por encima de Clemente VII; el señor del mundo por encima de Francisco I y de Enrique VIII: lúcido, preciso, guerrero pacifista. (USIGLI, TC II, p. 845).

A rubrica não funciona como uma estratégia cênica de romper o efeito ilusório da trama representada. O intuito da enumeração das características do monarca visa, mais obviamente, a oferecer material que servirá ao ator para a composição da personagem. No entanto, concomitantemente, não é possível descartar a interpretação de que existe uma voz didascálica que, no todo da obra, não objetiva somente a exposição de informações histórico-contextuais. Estamos diante, portanto, de um tratamento da história com a mesma perspectiva crítica, mas feita ainda no nível textual e não no cênico.

Por essas divergências, a resposta à pergunta de se a historiação de Brecht, por meio do efeito de distanciamento, seria o mesmo que anti-história de Usigli será um não modalizado... Se a imaginação dá o tom ao teatro anti-histórico e se o que permite esse tom é "la proximidad psicológica de los personajes" e não o "esqueleto de la cronología” (USIGLI, 1985, p. 27), então ser anti-histórico é sair da história para poder enxergá-la de longe, de modo a se ter uma visão panorâmica do tempo do tema tratado. Nesse sentido, ao tomar distância do fato, a anti-história usigliana se aproxima do distanciamento brechtiano. Porém, os recursos estéticos mobilizados para essa finalidade são diferentes em ambos os dramaturgos.

\subsection{Teatro histórico e documental}

O dramaturgo Juan Mayorga (2010), um dos representantes máximos do "teatro da memória" da Espanha (segundo a definição de seu conterrâneo José Sanchis Sinisterra), explica que

El teatro histórico - incluso el de vocación más historicista - es una - paradójica - victoria sobre la visión historicista del ser humano según la cual éste se halla clausurado en su momento histórico, del que es producto. Porque la condición de posibilidad del teatro histórico no es aquello que diferencia unos tiempos de otros, sino aquello que atraviesa los tiempos y que permite sentir como coetáneo al hombre de otro tiempo." (MAYORGA, 2010, p. 32). 
As palavras do autor espanhol colocam em evidência, mas sem conceitualizálas, as ideias mobilizadas nos gêneros dramáticos que dialogam com a história: o histórico, o documental e o da memória.

Também a crítica uruguaia Silka Freire (2007), ao estabelecer os objetivos de sua pesquisa acerca do teatro documental na América Latina, nos recorda algo mais no que diz respeito a esse gênero (que podemos estender aos outros): a confluência do documento e do referente histórico com vistas à ficcionalização por meio de mecanismos de teatralização produz um processo de intertextualização.

Portanto, ao darmos atenção à análise que ela faz de obras como Martirio de Morelos (1981), de Vicente Leñero, identificamos que, no cerne da estética desses gêneros dramáticos, se encontram as mesmas questões expostas pelo dramaturgo espanhol.

Com efeito, nas obras de extração historiográfica faz-se necessário reconhecer uma perspectiva de história (no sentido brechtiano) que "permite sentir como coetáneo al hombre de otro tiempo" (MAYORGA, 2010, p. 32) e simultaneamente constrói uma relação com um texto anterior. Por isso, ao finalizar essas reflexões acerca da relação literatura e história, vamos estabelecer alguns eixos conceituais de duas vertentes dramatúrgicas que sempre promovem uma relação direta com a história e a historiografia.

Costuma-se denominar "histórico" a um variado número de peças que representam fatos reconhecidos e consagrados pelos historiadores. São escolhidos como sujeitos da ação personagens "reais" como reis, presidentes ou indivíduos que se destacaram em algum processo de conquista ou em guerras. Nesse sentido, são tão históricas as obras shakesperianas Ricardo III y Henrique V como El cerco de Numancia, de Miguel de Cervantes.

Ainda que se reconheça a liberdade e a invenção na reconstrução dos fatos ${ }^{40}$, o teatro histórico é frequentemente criticado por sua tendência a confirmar a perspectiva dos poderosos no processo de narração do passado. Critica-se o uso a favor da legitimação de um relato oficial, que geralmente nega os conflictos e contradições dos processos históricos.

\footnotetext{
40 "Because drama by its very nature must be dramatic and adaptable for the stage, the writer usually has to select, arrange, and modify the data of personalities and events" são palavras do crítico inglês Herbert Lindenberger (apud FREIRE, 2007, p. 17) acerca dessa liberdade inventiva. Da mesma maneira, o dramaturgo mexicano Rodolfo Usigli escreveu no Prólogo a Corona de luz: o autor deve obedecer à verdade dramática quando se leva um fato histórico ao palco.
} 
No tocante à escrita, o drama histórico, sobretudo o da época moderna, tem como característica fundamental a construção a partir dos registros documentais. Assim como na ciência da história, o documento confere legitimidade ao evento representado. Nesse sentido, a questão que emerge é da (im)possibilidade de recriar a realidade ou de representá-la — problema fulcral da própria literatura e da arte em geral, como vimos anteriormente.

Com o propósito de mostrar "o que realmente ocorreu", se compreende melhor a re-presentação. Trata-se de pôr o passado no presente; isto é, transformar o passado de novo em presente. Essa convicção remete, no âmbito da criação que não se baseia na história (a que poderíamos chamar espontânea), à mise en scène de caráter naturalista, na qual se busca apresentar um retrato fiel à realidade, também tão criticada a partir das criações do teatro épico e do absurdo.

Ao mencionar o uso de documentos como recurso fundamental na construção do drama histórico e sua importância para a (des)legitimização enquanto obra artística, podemos passar à reflexão sobre o teatro documental ou docudrama. Nessa vertente, a base histórica (ou historiográfica) se opõe às propostas mais tradicionais de, através do teatro, assentar os pilares da história e confirmar a narrativa oficial hegemônica. Em outras palavras, o teatro documental se afasta do drama histórico tradicional, porque se interessa principalmente por promover uma história imediata daquilo que o discurso dominante quer esconder.

Erwin Piscator y Peter Weiss lançaram as bases desse teatro. Este último, em obras como El teatro documental y La investigación, o uso de vídeos, cartazes, trechos de documentos oficiais e históricos, manchetes de jornal, notícias etc. objetiva criar um efeito de realidade que permite problematizar a apresentação oficial dos fatos. Por isso, se atribui ao teatro documental a categoria de político. No entanto, a transposição não se realiza automaticamente. Como expressou Vicente Leñero em entrevista ao crítico mexicano Armando Partida Tayzan (2002a, p. 230): “Hay que darle un vuelco a la imaginación y una concepción teatral diferente a la simple translación de documentos al teatro".

Um ponto significativo a ser considerado para a diferenciação das duas propostas é a comprensão do que quer dizer "histórico" em ambas. Em outras palavras, uma das formas de estabelecer a diferença é por meio da identificação do quão distante está o autor dos acontecimentos. Esse limite é estabelecido sutilmente por Judith I. Bisset (1985, p. 73). Ela propõe que, enquanto o teatro histórico representa ações de um passado 
distante das vivências do autor e do espectador, o docudrama trabalha com fatos contemporâneos a ambos ${ }^{41}$. Já Patrice Pavis (2002), seguindo o caminho aberto por Lukács no Romance histórico, amplia essa questão, ainda que não esteja muito seguro dela. A partir do comentário às cartas escritas por Marx e Engels a Lasalle a propósito de sua obra histórica Franz von Sickingen, Patrice Pavis (2002, p. 9-10) faz a seguinte observação, entre parêntesis: "Quizás existe drama histórico desde el momento en que lo individual y lo privado son observados como fenómenos públicos y políticos".

O critério de Bisset (1985) demonstra-se restritivo, pois conforme discutimos anteriormente é possível tornar "histórico" um tema do presente. Mais do que no romance, que possui a categoria do narrador que, eventualmente, pode se imiscuir às reminiscências do autor, no teatro se recorre constantemente a um tema histórico para criticar uma situação conflituosa e/ou autoritária do presente. Por outro lado, observemos como a definição de Patrice Pavis se aproxima do parâmetro que instituímos para o histórico: a consagração, por um ramo do saber (a ciência histórica e os historiadores), de um evento que teve/tem impacto em uma coletividade.

Portanto, com relação aos gêneros dramáticos que propõem uma intertextualidade com a historiografia, sublinhamos que a diferença essencial está na intencionalidade. Tanto o drama histórico como o docudrama partem de textos nos quais a história se circunscreve, mas o propósito de negar ou de legitimar uma mentalidade hegemônica marca seus limites. A distância temporal possui relevância na medida em que quanto mais afastados autor e espectador estão dos fatos mais se busca dialogar com as construções de um imaginário forjado a posteriori do evento gerador, enquanto que a proximidade dos fatos objetiva oferecer uma nova possibilidade de vê-los e de senti-los.

Embora possamos considerar, pelo nome, o teatro documental um gênero muito próximo àqueles de extração histórica, no geral a crítica de teatro não os trata assim. O estabelecimento de uma diferença — na verdade, a falta de uma aproximação — é consequência de uma análise que lê as obras mais pelo contexto em que foram fabricadas do que pelas estruturas e estratégias composicionais. O drama histórico está tradicionalmente vinculado a certas situações políticas em que emergem posturas nacionalistas. Esse teatro serve, então, como confirmação de um discurso oficial.

\footnotetext{
${ }^{41}$ Because the incident the play recalls is no longer a part of living communal history (i.e. no one now living experienced the event), it can be classified as historical drama. [Porque o evento recordado pela obra já não é parte da história vivida pela comunidade (isto é, ninguém agora vive a experiência do evento), ela pode ser classificada como drama histórico]. (BISSET, 1985, p.73)
} 
Outro fator condicionante da rejeição desse gênero está em sua origem. Tendo alcançado o auge no século XIX, quando a figuração realista-naturalista imperava em todas manifestações artísticas, o drama histórico mantém uma configuração pautada pela fidedignidade ao tema representado de modo que a contestação, seja pela quebra do efeito de "suspensão da realidade", seja pela inconsistência entre o registro historiográfico e o argumento desenvolvido no palco, é vista como um defeito da composição e, por isso, algo a ser evitado.

$\mathrm{Na}$ outra ponta, o teatro documental parece opor-se ao histórico. Sua emergência e sedimentação na primeira metade do século XX correm em paralelo com uma série de propostas ideológicas cujo alvo é a contestação e o rompimento de regimes políticos e mudanças sociais. Assentado nessas bases, suspender a "suspensão de realidade" e apresentar um episódio em contradição com os registros ou com o imaginário são procedimentos louvados e requeridos, por dramaturgos e pelo público. A contestação se torna mais intensa porque o questionamento é, frequentemente, do presente. Mesmo no Brasil dos anos sessenta e setenta, o "histórico" de peças como Calabar e Liberdade, liberdade é quase sempre a paródia do presente.

No entanto, se nos aproximamos desses gêneros com chaves mais literárias do que sociológicas recuperamos uma dimensão significativa da forma dramática. Como a história, quer a escrita do passado quer a imediata, demanda o trabalho com as fontes documentais, inferimos que são compatíveis a camada textual que cimenta a arquitetura de uma e outra dramaturgia.

No teatro mexicano, história e documento se fazem presentes de forma tão intensa nos diferentes períodos que fica difícil, enquanto pesquisador, tratar com indiferença um tema que interessa tanto à crítica teatral em geral quanto à história do teatro mexicano em particular.

Assim é que, durante o porfiriato, é fácil encontrar obras de cunho reprodutor do discurso oficial ${ }^{42}$. No século XX, a confluência do conhecimento das técnicas do teatro épico e as aspirações revolucionárias abriram passo a expressões artísticas que recuperam o histórico — remoto ou imediato - para pensar a nação e concomitantemente o próprio fazer dramatúrgico. À medida que pretendiam se afastar do discurso oficial, as peças

\footnotetext{
${ }^{42}$ Bastante simbólico desse aspecto é a comédia de costumes La hija de um cantero, representada em 1862. Dois autores assinam a escrita, Don Juan A. Mateos e um general, Vicente Riva Palacio. Para leitura da resenha dessa peça, consultar-se Miguel Ángel Vásquez Meléndez, México personificado: un asomo al teatro del siglo XIX, INBA, 2012.
} 
possuíam enredos que representavam o processo de escrita da história. A fim de dar conta da complexidade desse tema, técnicas metateatrais quase que naturalmente brotam das obras. Questionamento do documento, questionamento da história; dúvida sobre o histórico, dúvida sobre a representação. No México, na dúvida entre ter que escolher ou as convicções do drama histórico ou a tentativa de dar aos eventos imediatos uma nova textura, a opção mais convincente foi optar pelas duas alternativas a fim de criar um elo entre autores de diferentes períodos.

\subsection{O discurso histórico-narrativo nas didascálias}

Uma das peculiaridades do texto dramático é a presença de um discurso paralelo ao das personagens, a rubrica. Diferente da prosa romanesca, em que se destaca a voz narrativa na organização e encadeamento dos episódios, esse discurso não controla nem concentra a ação. $\mathrm{O}$ romance se aproxima mais da historiografia porque ambos possuem um elemento comum, a narrativa (RICOEUR, 1994 e WHITE, 2008). Nesse sentido, poderia parecer estranho buscar com o texto dramático aproximação no nível discursivo-textual. Porém, em sintonia com o que temos discutido, pensamos que a simbiose da história com o texto dramático proporciona efeitos de sentido instigante tanto pela maneira de se apresentar quanto pela viabilidade ou não de serem levados à cena. Devido à sua importância, dedicaremos o sexto capítulo especificamente a analisar esse aspecto na dramaturgia mexicana. Por ora, também em consonância com o que até agora foi apresentado, queremos lançar os marcos teóricos que balizam as reflexões acerca desses efeitos de sentido.

Assim, vemos que na literatura dramática, a didascália é um elemento compositivo que sinaliza os atos ilocucionários de algumas falas das personagens e, ao mesmo tempo, expande os movimentos representados para fora do mundo e do tempo da leitura. É responsável não pela dramaticidade entre as personagens, mas pela tensão entre o texto impresso e o texto cênico. ${ }^{43}$

\footnotetext{
${ }^{43}$ Chamaremos de "texto cênico" o espetáculo teatral, ou seja, a realização, em um espaço aberto ou fechado, de uma representação de um texto pensado para ser montado e mostrado. Em síntese, trata-se de um sinônimo para, em espanhol, puesta en escena, ou, em francês, mise en scène.
} 
Didascália, rubrica ou indicação cênica (acotación escénica $)^{44}$ são termos usados para designar, basicamente, os elementos compositivos de uma obra teatral escrita, os quais não fazem parte dos diálogos dos actantes. Esses elementos frequentemente sofrem mudanças tipográficas. Uso de caixa alta para indicar as personagens; o itálico para as movimentações, entradas e saídas; a delimitação, com uso de parênteses, para prescrever que lugar os objetos devem ocupar no palco: todos são recursos facilmente reconhecíveis na estrutura composicional de um drama. Essa definição, porém, não é suficiente para abarcar o fenômeno completamente. Isso porque, como ensina Ubersfeld (2005, p. 6), "a relação textual diálogo-didascálias é variável de acordo com as épocas da história do teatro".

O teatro grego, por exemplo, prescinde quase sempre das rubricas enquanto marcações alheias às falas das personagens. Para ilustrar, recordemos as palavras iniciais de Prometeu acorrentado:

\section{O PODER}

Eis-nos chegados aos confins da terra, à longínqua região da Cítia, solitária e inacessível! Cumpre-te agora, ó Vulcano, pensar nas ordens que recebeste de teu pai, e acorrentar este malfeitor, com indestrutíveis cadeias de aço, a estas rochas escarpadas. Ele roubou o fogo - teu atributo, precioso fator das criações do gênio, para transmiti-lo aos mortais! Terá, pois, que expiar este crime perante os deuses, para que aprenda a respeitar a potestade de Júpiter, e a renunciar a seu amor pela Humanidade. (ESQUILO, s/d, p. 113).

O negrito, o sublinhado e o itálico não constituem, obviamente, o texto original. Todavia, os inserimos para destacar de que forma, já na fala de uma das personagens, no caso o Poder, existe a indicação do local onde se inicia a peça e se faz menção a um objeto que deverá constar como fundamental na peça, as "cadeias de aço", ou seja, as correntes. Além disso, os dêicticos "este" e "ele" designam a presença do protagonista, Prometeu.

Da mesma forma, o teatro elisabetano procurava lançar, nas falas dos actantes, as sugestões dos gestos que os atores deveriam exercitar na representação. Na cena II do segundo ato de Hamlet, o Rei e a Rainha pedem a Rosencrantz e Guildenstern que fiquem um tempo com o Príncipe na corte para levá-lo “aos prazeres”, porquanto está passando

\footnotetext{
${ }^{44}$ Em espanhol, o termo "didascália" parece ser preponderante, embora seja aplicado em paralelo com “indicação cênica”. Este último é, aliás, preferido por Patrice Pavis em seu Dicionário do Teatro (apud TAVIEL DE ANDRADE, p. 82). Em português, a "rubrica" parece ocupar mais espaço do que "didascália". Neste trabalho, utilizaremos, indistintamente os três termos, uma vez que quaisquer um tem aceitação nos estudos teatrais e literários.
} 
por transformações que os reis consideram muito estranhas. Os amigos de Hamlet aceitam o pedido e, ao término do diálogo, Guildenstern assim se expressa: "E nós ambos nos inclinamos, depondo humilde e livremente a vossos pés nossos serviços para o que quiserdes ordenar" (SHAKESPEARE, 2001, p. 40). O trecho aqui em negrito ilustra que a inclinação não é apenas uma forma metafórica de expressar a obediência dos amigos à ordem dos reis.

No século XIX, definem-se novas estratégias de composição por meio de didascálias alheias aos diálogos propriamente ditos, principalmente com o teatro naturalista, de acordo com Luiz Fernando Ramos em O parto de Godot (1999). Enquanto objeto de interesse analítico, as rubricas passam a atrair olhares críticos que irão permitir tomá-las sob o ponto de vista teórico.

Dentre essas perspectivas, destaca-se a opinião de Roman Ingarden (1971), para quem o teatro se divide em texto primário (os diálogos) e secundário (as didascálias). O teórico alemão adota uma postura hierárquica nessa classificação. As rubricas são secundárias porque estão fadadas a desaparecer na encenação. Por seu turno, Jean Marie Thomasseau ("Les différents états du texte théâtral" ${ }^{45}$ ), prefere o termo paratexto:

Texte aléatoire, provisoire, d'étendue variable, distingué, en général, du texte dialogué par une typographie en italique dans les éditions imprimées. C'est un texte dépourvu de toute trace d'oralité mais "texte à voir" qui participe, lors de la lecture, à la mise en place de l'espace dramatique psychique du lecteur. Ce même texte, interprété, manipulé, tronqué, oublié par le metteur en scène, servira à la construction de l'espace ludique visible-audible par le spectateur. (...) Le para-texte est voulu, au départ, comme un texte purement informatif, à destination d'un régisseur, accessoirement d'un lecteur (apud TAVIEL DE ANDRADE, 1996, p. 82).

O crítico francês, em sintonia com Roman Ingarden, afirma tratar-se de um texto "aleatório", "provisório", "puramente informativo", cuja compreensão só se realiza no sentido de assessorar o leitor, que tem acesso apenas ao espaço físico ocupado por ele no momento da leitura.

No entanto, já há algumas décadas, estudos de diversos pesquisadores demonstram o potencial literário das didascálias em autores como Eugène Ionesco, Ramón de Valle-Inclán, Samuel Beckett e José Celso Martinez Côrrea ${ }^{46}$. Esses

\footnotetext{
${ }^{45}$ In Pratiques, 41, 1984, p. 102.

${ }^{46}$ Apesar de este último não ser considerado dramaturgo no sentido mais convencional, fazemos essa referência apoiados no estudo comparado entre Beckett e José Celso Martínez Côrrea, fruto da tese de doutorado de Luiz Fernando Ramos (1999) da qual há uma síntese na primeira edição da revista Sala Preta (2001), publicação da Escola de Comunicação e Artes da Universidade de São Paulo.
} 
dramaturgos, de nacionalidades distintas, investem na expansão das rubricas para além das indicações ou anotações cênicas. O fato de alguns autores dedicarem-se mais que outros às formas de expressão das rubricas não está, porém, relacionado apenas aos projetos individuais de cada um.

Procurando compreender por que, no século XX, a preocupação com a criação das didascálias vai além das marcações para a montagem, Taviel de Andrade (1996, p. 83) elenca três circunstâncias:

a) el personaje deja de ser un simple rol y adquiere rasgos individuales, esto es, se busca a un individuo socialmente marcado que permita su identificación con el espectador;

b) se opera un incremento de la acción en detrimento de lo dicho;

c) se asiste a un aumento progresivo del gusto del público por el espectáculo visual, que corre parejo con la evolución de los medios técnicos y con la ampliación del espacio escénico.

Acrescentaríamos a essas mudanças as pugnas entre teatro de autor e teatro de diretor, intensificadas a partir da década de 60 do século passado. Da mesma maneira se expressa Luis Cláudio Machado (2011, p. 35): "uma reflexão sobre a rubrica é inseparável da polêmica sobre a dialética PALCO/TEXTO e coloca o problema das relações entre autores e diretores". Nesse conflito, o diretor busca uma concepção teatral que não seja a de meramente ilustrar o texto ao passo que o autor rejeita a montagem do espetáculo em razão do afastamento da concepção cênica do diretor.

Finalmente, é preciso reconhecer uma última circunstância no processo de variações das funções didascálicas, seja como matéria de criação, seja de crítica. As mudanças no sistema de produção cultural criaram diversas especializações do fazer teatral. Para melhor compreender o problema, podemos estabelecer uma analogia com o cinema, cuja criação - sabemos — nasce no auge do sistema capitalista. O roteiro, por exemplo, prescinde de indicações precisas e reduz o texto aos elementos básicos da narrativa, entre outros fatores, porque há, além do diretor do filme, o de fotografia e o artístico, este último, responsável por criar os cenários. Além disso, a partir da década de 70 é difícil conceber um artista das artes dramáticas (ator, produtor, diretor e autores) que não transite também pelo teatro, cinema e TV.

Portanto, mudanças culturais e sociais, mudanças na concepção de espetáculo, alterações de gosto do público, essas e outras circunstâncias, que poderiam ter desestabilizado a criação dramatúrgica, parecem ter produzido um incremento das formas de elaborar as indicações cênicas. Se até o desenvolvimento do teatro naturalista não 
havia dúvidas de que o autor realizava a concepção total da obra e de que o diretor era tão acessório quanto muitos elementos do cenário, o século XX e, sobretudo após a segunda metade, com o espetáculo sobrepondo-se à linearidade espacial do texto literário, criou condições para a exploração do potencial de ficcionalidade e literalidade das rubricas. ${ }^{47}$

As palavras anteriores exigem a reflexão acerca da tensão realidade - ficção inerente ao próprio texto dramático. Partindo das hipóteses de Michael Issacharoff em "Voix, autorité, didascalie" (1993), Luiz Fernando Ramos explica que as duas formas textuais em que se dispõe o gênero dramático têm destinatários diferentes. Se os diálogos são para os atores, que estão encarregados de dizê-los, as rubricas visam aos operadores da montagem, mas não são pronunciadas; os primeiros constituem a parte ficcional do texto, ao mesmo tempo em que as segundas configuram a dimensão "real". Devemos acrescentar a essa diferenciação dos destinatários estabelecida por Issacharoff (apud RAMOS, 2001) um aspecto que é ponto pacífico na semiologia do teatro, a saber: que o destinatário "final" do texto é o público. Nesse sentido, poderíamos questionar se as rubricas não seriam também elementos que deveriam "aparecer no palco".

O teatro do século XX realizou essa operação. Em obras como em Historia de Él (da barcelonesa radicada no México Maruxa Vilalta), um "Leitor" aparece em cena e dita às personagens os gestos, expressões e movimentos a serem realizados no palco. Trata-se de uma estratégia de metateatralidade cujo propósito é potencializar novos recursos que permitem questionar certas regras da criação dramática e, por extensão, o estatuto de ficcionalidade.

Com efeito, as didascálias, rubricas, acotaciones escénicas ou stage directions merecem o exame meticuloso por parte do estudioso do teatro e da literatura. Nas palavras de Luiz Fernando Ramos (2001, p. 12), “elas inscrevem no plano literário a dimensão física e tridimensional da cena e, assim, não só articulam a encenação no plano imaginário, como garantem a sua consistência enquanto ficção".

\footnotetext{
${ }^{47}$ A fim de reforçar nossa tese neste ítem, a qual defende a possibilidade de ver, através das didascálias, a concepção cênica de uma obra dramática, lembramos que as circunstâncias que conduziram às mudanças na forma das rubricas se coadunam com as características do teatro pós-moderno elencadas pelo chileno Alfonso de Toro (2005), professor da Universidade de Leipzig. Segundo o crítico, na pós-modernidade a representação configura-se mais pela performance do que pela expressão textual. Quando o texto parece ganhar mais espaço, vê-se a emergência de uma profusão de citações com vistas a desconstruir o teatro moderno, realista, tradicional. Tempo, espaço e ação são concebidos como fragmentos, simulacros, enfim, aspectos incompletos. Consequentemente, existem pseudo-narrativas, mais reduzidas ao gesto do que a um argumento. Essas reflexões não avançam a ponto de poder serem designadas de pós-dramáticas, no sentido de Hans-Thies Lehmann (2007), uma vez que, para o encenador alemão, o teatro pós-dramático prescinde do discurso verbal enquanto princípio da criação teatral. O texto é uma camada e não o regente do drama. (LEHMANN, 2007, p. 19).
} 
Teóricos como Issacharoff e Simone Dompeyre ${ }^{48}$, cônscios do potencial ficcional desse texto, buscaram classificar as didascálias. O primeiro utiliza o critério das funções comunicativas: quem fala, para quem, onde e em que tom. Por conseguinte, as rubricas seriam nominativas ou atributivas, destinativas, locativas e melódicas. Por seu turno, Dompeyre usa o critério da localização dentro da publicação. Assim, rubricas liminares seriam aquelas que estão no início do texto; intermediárias, no começo de cada ato, e as intersticiais aparecem no início e no meio das falas.

Ambas as classificações, no entanto, não conseguem abarcar todas as estratégias que encontramos nos autores e obras que compõem o corpus de nossa pesquisa. Além disso, as duas classificações parecem estar apegadas ainda à concepção de que as didascálias têm a missão de simplesmente indicar os movimentos, gestos, elementos, enfim, aquilo que compõe a "realidade" da cena. Elas não auxiliam na compreensão de que existem modos de construir a rubrica que extrapolam o estatuto de realidade necessário à encenação. Portanto, usaremos em nosso texto algumas dessas categorias, levando em consideração suas limitações e sem pretender que as obras estudadas se adaptem a elas completamente.

Por outro lado, precisamos dizer desde já que o intuito não é criar uma classificação das estratégias de rubrica, pois, além de ser uma tarefa complexa, nenhum dos autores de nossa pesquisa busca, efetivamente, uma transformação radical do texto teatral através delas. Parece-nos que uma classificação periga resultar tão subjetiva quanto aquela realizada por Jorge Luis Borges no conto "La biblioteca de Babel" e mencionada por Foucault em As palavras e as coisas.

Para ilustrar os efeitos de sentido provocados pelo uso da didascália na dramaturgia mexicana, recorremos brevemente a uma obra que, embora não componha o corpus escolhido, exprime com relevo a absorção da história pelo texto dramático e a consequente ampliação de seus recursos técnicos. Escolhemos essa obra não só pelas próprias qualidades que carrega, mas, sobretudo, porque o corpus terá as didascálias meticulosamente esquadrinhadas, de modo que preferimos não adiantar essa análise.

Trata-se da peça Felipe Ángeles, de Elena Garro. Escrita em 1956, aborda a história de uma personagem homônima ao título, a qual foi emblemática na Revolução Mexicana:

\footnotetext{
${ }^{48}$ Infelizmente, não tivemos acesso direto a esses teóricos. As informações que utilizamos neste momento são oriundas de Ramos (2001) e Taviel de Andrade (1996), respectivamente.
} 
ACTO I

La acción pasa en la ciudad de Chihuahua el día 26 de noviembre de 1919. Fachada del Teatro de los Héroes. [...] Al fondo del vestíbulo los cortinajes rojos ocultan la entrada a sala de espectáculos. Son las siete de la mañana.

Entran el general Diéguez y el coronel Bautista. Vienen cubiertos de gruesos capotes militares de invierno. Diéguez se detiene en la escalinata y distraído empuja con el pie algunos restos de la nieve que ha caído la noche anterior. Son las siete de la mañana.

(GARRO, 2009, p. 82)

Nessa abertura, dois aspectos significativos demonstram o potencial da didascália para a criação da ficcionalidade. Inicialmente, se realiza um tom narrativo no texto, em semelhança com o romanesco-prosaico, a partir do uso de marcadores temporais que denotam tanto a hora dos acontecimentos como a passagem do tempo. Chama atenção ainda a reiteração do horário da cena, a qual proporciona um efeito de expectativa. Por fim, o uso do pretérito composto para indicar que "la nieve ha caído".

O uso verbal no passado parece desequilibrar a experiência de leitores acostumados ao texto dramático porque, no teatro, como o tempo da leitura e o do desenrolar dos fatos é simultâneo (HAMBURGER, 1986), prevalece o presente. A neve, então, quando o telão é alçado e o espectador a vê no palco, não produz a sensação de "nevou”, mas sim "está nevando", "neva” enquanto essa história acontece. A didascália de Garro (2009) lida isolada e completamente poderia ser tomada como a introdução de um romance histórico. ${ }^{49}$

Outra marca relevante da importância das rubricas para a ficicionalidade do texto teatral provém da sugestão de metateatralidade que poderá ocorrer, fenômeno possível devido à ambientação do general Diéguez, que está em frente ao Teatro de los Heroes.

Como não faz sentido neste momento aprofundar a leitura dessa obra, após a exposição dos principais problemas que envolvem o texto didascálico, em momento oportuno, pretendemos, então, primeiramente, elencar algumas estratégias de rubrica de que lançam mão os autores a que nos dedicamos nesta pesquisa. A seguir, através da análise das didascálias, queremos verificar os efeitos de sentido criados e a possibilidade de serem ou não mostrados ao espectador.

\footnotetext{
${ }^{49}$ Recordemos ainda o ensinamento de Käte Hamburger (1986) segundo o qual o pretérito perfeito é uma convenção da arte romanesca e não indica, necessariamente, que algo passou.
} 
PARTE II - Autores, obras e contexto histórico 


\section{Capítulo 3 - Rodolfo Usigli: A história descoberta}

Queremos dedicar este capítulo inteiramente a esse dramaturgo que, além do trabalho como diplomata, passou grande parte da vida sedimentando a ideia de um teatro mexicano (e não apenas um teatro para o México). Peças, oficinas, cursos, conferências, ensaios fazem parte da obra de Usigli. Seu Teatro Completo está editado em quatro volumes pela Fondo de Cultura. E tão extensa quanto a obra é sua fortuna crítica.

Tendo em vista a ampla atuação desse intelectual para a construção de um teatro mexicano, preferimos abordá-lo em três dimensões. A divisão atende a um princípio meramente expositivo; como se verá, ação, pensamento e reflexão são complementários em sua carreira. Primeiramente, preocupamo-nos com o exercício de atividades voltadas ao teatro. Em um segundo momento, damos atenção a escritos em que as reflexões sobre a arte dramática estão imbricadas às análises políticas e às interpretações de seu país. Por fim, procuramos explicitar o desenvolvimento de uma estética a partir de obras em que se manifestam mais intensamente os processos de ficcionalização da história. A fundamentação para compor essa grande personagem encontra-se em ensaios, artigos, prólogos e epílogos escritos pelo próprio dramaturgo. Entrevistas concedidas, artigos e estudos mais aprofundados (tal como Teatro para caníbales, de Peter Beardsell, 2002) auxiliam-nos nessa tarefa na medida do necessário.

Rodolfo Usigli nasceu na Cidade do México em 1905. Filho de pais imigrantes (sua mãe, Carlota Wainer, tinha origem polaca e seu pai, Alberto Usigli, era italiano), tem seus primeiros contatos com palco realizando teatro de fantoches e fazendo figuração. A profissionalização começou em 1924, quando escrevia crônicas e realizava entrevistas sobre o mundo teatral. Ávido leitor da dramaturgia francesa e inglesa, traduziu Schnitzler, Bernard Shaw, Molière, Tchekov e O’Neill,

Em 1932 editou um dos primeiros livros analíticos sobre a história do teatro em seu país (México en el teatro). Nesse mesmo ano começaram suas aulas sobre história e técnica teatral em cursos de verão na Faculdade de Filosofia e Letras da Universidade Nacional Autônoma do México (FFyL-UNAM). Esses cursos seriam os germens de uma longa jornada de ensino que resultaria na formação de novos dramaturgos, diretores e críticos teatrais, dentre os quais se destacam Luisa Josefina Hernández, Jorge Ibargüengoitia, Emilio Carballido, Héctor Mendoza, Sergio Magaña y Luis G. Basurto. 
Junto com Xavier Villaurrutia, foi bolsista da fundação Rockefeller para estudar técnicas de composição dramática e direção, em Yale. Poucos anos depois, em 1939, publicava Anatomía del teatro, texto em que, segundo Beardsell (2002), a crítica à falta de um teatro autenticamente nacional se tornou mais mordaz.

Entre 1944 e 1947, durante o governo do presidente Manuel Ávila Camacho, esteve na França. Nesse período, aproveitou para entrevistar, em 1945, Bernard Shaw, quem teria grande impacto em sua produção dramatúrgica.

A partir do momento em que passou a se ocupar da representação mexicana no exterior, Usigli afastou-se dos grandes movimentos coletivos do teatro. Um exemplo foi que, quando ocorreu uma das experiências mais consistentes da arte dramática mexicana, o grupo Poesía en Voz Alta, ele esteve no Líbano, como enviado especial. Ao contrário da trajetória seguida por alguns dramaturgos de sua geração, tais como Salvador Novo e Xavier Villaurrutia, seu vínculo com o Estado não o manteve entre os cargos de chefia de departamento e direção de instituições culturais e universitárias.

Entre 1973 e 1976, empreendeu um projeto de teatro popular, criado a partir da solicitação do presidente e seu ex-aluno na UNAM, Luis Echeverrería Álvarez, que havia sido eleito em 1970 e a quem Usigli dedicara sua última peça, ;Buenos días, señor presidente! (1972). Parecia que enfim encontraria o tipo de ambiente que tanto fortaleceu não apenas aqueles dramaturgos de sua geração como também os mais novos ${ }^{50}$. Interessante observar que, hoje, a pesquisa e a memória do teatro mexicano estejam a cargo de um centro que leva o seu nome, o CITRU (Centro de Investigaciones Teatrales Rodolfo Usigli).

Durante seus setenta e quatro anos, nunca abandonou o teatro nem deixou de pensar seu país. Mesmo no exterior, escreveu diversas obras, ensaios, resenhas, prólogos e epílogos em que, à maneira de outros intelectuais dos anos 30, 40 e 50, demonstrou-se um intérprete dos problemas que acometiam o México e o teatro, sempre tomando este último como ponto de partida - e de chegada.

\footnotetext{
${ }^{50}$ No que diz respeito às oportunidades propiciadas pela ocupação de cargos públicos de instituições governamentais, é singular o caso de Héctor Azar (1930 - 2000). No fim dos anos 60 e princípios do 70 ele acumulou a Chefia do Departamento de Teatro do Instituto Nacional de Bellas Artes (INBA) com a direção da Casa del Lago (órgão subordinado à UNAM que funciona até hoje no bosque de Chapultepec). Como já havia fundado, em 1965, a Companhia de Teatro Universitário, sua influência política na produção cultural provocou a ira da classe artística teatral a ponto de que, em 1973, um grupo de artistas ocupou o Foro Isabelino da UNAM e prometeu sair assim que Azar abrisse mão dos dois cargos.
} 
México en el teatro ${ }^{51}$, em sua edição de 1996, é composto de treze capítulos, um resumo cronológico do teatro e um apêndice intitulado "Primeros apuntes sobre el teatro", no qual se incluem cinco artigos que não constavam na primeira edição. Inicialmente, o título leva-nos a pensar em uma abordagem nacionalista das representações e figurações do país em obras teatrais. Trata-se, no entanto, de uma historiografia do teatro mexicano desde as expressões indígenas anteriores à Conquista, até os experimentos dos anos 30, na qual transparece sempre o empenho do autor em buscar uma tradição a que pudesse se filiar.

Essa postura frente à tradição revela um dramaturgo amadurecido o suficiente a ponto de esboçar um projeto estético sólido. Se comparado, por exemplo, ao crítico Francisco Monterde, de quem Usigli prefaciou, em 1933, sua volumosa história do teatro, não será difícil perceber sua relevância para a cultura. Perto das mais de 600 páginas de Monterde, México en el teatro pode ser considerado tímido. Por outro lado, o livro de Usigli afasta-se do estilo catalográfico e cronístico.

A tentativa de se integrar a uma tradição pode ser compreendida traçando-se um paralelo com o sentimento de orfandade de que fala Octavio Paz em El laberinto de la soledad (1950/1998). É como se Usigli tomasse consciência de seu papel na história e tentasse se filiar a ela.

Conforme o próprio autor sinalizou nas notas de preparação para a segunda edição:

Me parece interesante conservar dos cosas: el plan original, panorámico e informativo, y el estilo informal, casi conversado, por su espontaneidad y frescura, que ayuda al lector a penetrar en problemas que, expuestos en forma académica, le repugnarían. (TC IV, p. 233 nota 84$)^{52}$.

Essas palavras revelam um autor consciente do que está produzindo e preocupado em atingir um universo que ultrapasse os letrados e o público específico esta última postura pouco a pouco deixará de ser evidente em sua trajetória. Verificamos que Usigli seleciona os momentos, autores e obras que deseja iluminar, não pelo que

\footnotetext{
${ }^{51}$ Em 1947, preparou um projeto de segunda edição, em que esboçava o que deveria ser mantido e retirado. No ano seguinte, escreveu uma "Advertencia". No entanto, essa publicação não foi levada a cabo pelo dramaturgo. Não nos foi possível ter acesso a essas obras "originalmente". Nossa leitura, então, está toda fundamentada na reedição que a Fundo de Cultura reuniu no volume IV do Teatro completo (1996), compilada, introduzida e anotada por Luis de Tavira.

${ }^{52} \mathrm{~A}$ menos que haja alguma exceção, a referência às obras de Usigli será feita apenas pela abreviação TC (Teatro Completo), seguida de numeral em romano, de modo a assinalar de qual dos quatro volumes se trata.
} 
recorta da história literária, mas pelo que deseja inserir em um projeto estético pessoal. Por exemplo, lembrando sempre o empenho evangelizador das ordens religiosas, ele elenca o teatro e as expressões cênicas dos povos pré-colombianos e dos primeiros espanhóis, como as danças e os rituais religiosos. No entanto, essas manifestações são apenas reconhecidas, isto é, em nenhum momento ele expressa o desejo de incorporá-las em sua estética. Para ele, a existência de um teatro anterior e um posterior à chegada de Cortés não é suficiente para dizer que ali estão as raízes do teatro mexicano. Ele mesmo esclarece: "No debemos a los antiguos mexicanos las bases éticas o estéticas de un teatro nacional y todo esto no es sino curiosidad y divertimiento arqueológicos, deleite de eruditos. Por lo demás, tampoco las debemos a los españoles.” (TC IV, p. 42).

Percebemos, portanto, que uma leitura nacionalista no sentido da valorização e exaltação de um passado estático não faz parte dos planos de Usigli desde muito cedo em sua faceta como pensador de teatro. Identificamos também que ele tampouco afirma onde estariam as bases do teatro mexicano. No entanto, nos capítulos sobre Juan Ruiz de Alarcón e Virginia Fábregas, podemos ter uma ideia do que ele pensava.

Intitulado "Intermedio", o capítulo sobre Alarcón possui uma dimensão poética. Ali Usigli ressalta que a grandiosidade do teatro alarconiano está justamente no fato de ser mexicano e espanhol concomitantemente, já que o autor do século XVII, devido à combinação de tons herdados de sua dupla nacionalidade, "como todo cuanto producen las mezclas de razas o de costumbres, alcanzó la condición más universal, escapando a muchas de las convenciones hereditarias de las razas puras.” (TC IV, p. 79). Dentre as dimensões estéticas e éticas que exalta no autor de La verdad sospechosa, a maior delas é a universalidade e, ao mesmo tempo, lamenta a inexistência de seguidores.

Analisando a perspectiva que Usigli tem dos séculos XVI e XVII, notamos que não deixa de reconhecer obras como os autos sacramentais e outras expressões de divertimento na composição dos elementos dramáticos que conformariam o teatro mexicano, mas enfatiza que eles ainda se mantinham apegados à concepção medieval. Quando lembramos que Usigli traçou seu projeto em um contexto pós-revolucionário que se abria na direção de um futuro repleto de expectativas para seu país, fica mais fácil entender por que não era possível limitar as bases estéticas àquele período já tão remoto.

Por isso, outro ponto na história que se ilumina a partir de sua visão é a atuação de Virginia Fábregas. No capítulo "Linde", afirma que com ela "el público no estaciona en la contemplación de cosas inútiles y vanas, y los que asistieron al teatro entonces descubrieron, gracias a ella, un nuevo continente teatral: el de la educación." 
(TC IV, p. 152). Além do seu papel na educação teatral, enfatiza outro aspecto da atriz, diretora, produtora, tradutora e dramaturga: sua capacidade de estar além das fronteiras dos gêneros e das obras "autênticas". Em outras palavras, o trabalho de apresentar ao público mexicano obras de maior expressão internacional e não apenas produzidas no México, como era a prática herdada do porfiriato, na primeira década do século $\mathrm{XX} .{ }^{53}$ Nesse ponto, Rodolfo Usigli questionava o hábito comum de montar peças de gêneros teatrais mais voltados ao entretenimento e à pasteurização da cultura nacional (os chamados gêneros chicos), tais como o teatro de revista e o de carpa ${ }^{54}$.

Em contrapartida, é necessário mostrar o que ele afirma sobre outros dois autores. Primeiramente, uma voz mais próxima de Alarcón, soror Juana Inés de La Cruz. Para ele, as produções dramáticas da monja são exercícios da sua mais alta expressão, a lírica, mas "no tienen mayor importancia - ni siquiera la de adentrarse en una nueva forma o la de intentar por un segundo siquiera la creación de un teatro mexicano." (TC IV, p.95). Vale ainda notar que sobre Agustín de Castro - dramaturgo, romancista e intelectual do século XIX - Usigli pensa que seu único mérito é o de ter introduzido tipos, costumes e linguagem populares.

A ampliação dos elementos nacionais a partir do conhecimento de obras universais e a rejeição da imitação e do continuísmo de obras estereotipadas é o que mais se destaca dentre todas as características que Usigli sublinha em Alarcón e Fábregas.

A imitação, aliás, está no cerne das reflexões em momento posterior ao lançamento do livro México en el teatro. Esse conceito-chave para a arte em geral e para o teatro em particular, foi trabalhado intensamente até se transformar em um recurso metateatral, no sentido que lhe atribuem Lionel Abel (1968) e Manfred Schmeling (1982):

El más poderoso de los instintos de expresión del hombre es el imitativo, que es lo que da al teatro su carácter supremo de testimonio y manifestación y su calidad humana, que podrá evolucionar; pero que se apagará sólo con la extinción de la especie. (USIGLI, TC IV, p. 39).

A esse respeito, o "Epílogo sobre la hipocresía del mexicano", de 1938, atrelado às "Doce notas" publicadas doze anos mais tarde, é um dos ensaios mais significativos e esclarecedores do autor. Escritos a propósito da peça El gesticulador, seu

\footnotetext{
${ }^{53}$ É interessante notar que Usigli não menciona nenhum dos integrantes do grupo Contemporáneos, cujos propostas se aliavam às de Virginia Fábregas.

${ }^{54} \mathrm{Na}$ atualidade, muitos estudos têm ressignificado as contribuições desses gêneros para o teatro mexicano. Dentre os estudos, mencionamos apenas o de Socorro Merlín, Vida y milagro de las carpas: la carpa en México 1930-1950 (INBA-CITRU, 1995).
} 
principal mérito recai na exposição de princípios éticos e de motivações políticas, bem como numa interpretação sociológica e antropológica do ser mexicano. A partir desses textos ficam explícitas as motivações essenciais da estética usigliana.

No que tange às ideias sociológicas, o epílogo inicia-se com o relato de uma conferência que Usigli havia sido convidado a proferir em uma reunião do Ateneo ${ }^{55}$. O tema era o estado atual do teatro mexicano. O conferencista procurou orbitar sua fala sobre dois pontos, o caráter do mexicano e a profissão do ator, isto é, "de las incapacidades específicas del mexicano para ser un buen actor o un buen dramaturgo y crear un teatro propio en el país. Es decir, la falta de concentración por una parte; y por la otra la falta de verdad en su vida." (TC III, p. 453-454). Em seu raciocínio, o corolário dessa situação era que para se conseguir impulsionar um teatro nacional deveriam ser aproveitadas aquelas mesmas características. Assim, a "hipocrisia", que remete ao ator no teatro grego clássico, passa à condição de categoria ética estendida à estética.

À continuação, dá vários exemplos em que a hipocrisia mexicana se manifestaria, no cotidiano, na política e na história. Extrapolando o assunto da conferência, Usigli falava abertamente sobre o tema da violência doméstica no país. Para ele, havia muitos homens de bem que, no convívio social mostravam-se felizes e cordiais, enquanto no âmbito privado maltratavam mulher e filhos. Em contrapartida, as mulheres "atacavam" seus maridos de diversas formas: mediante a traição, o esbanjamento, a conjuração entre sogras e noras e "ainda no descuido com o próprio corpo". O hábito da mentira, que ele tipifica com a relação entre marido e mulher, seria outra nefasta característica do mexicano que teria se afiançado na história nacional a partir do momento em que os indígenas do Novo Mundo precisaram fingir sua adaptação diante dos colonizadores.

Seguiam-se outros exemplos em forma de crônicas do cotidiano, como a de um jovem que dentro de num ônibus se sentara no lugar do cobrador porque não havia outros assentos disponíveis e o funcionário encarregado da função estava conversando com o condutor. A partir de então, ele passa a se comportar como um excelente cobrador. Sua postura, seus gestos, seus olhares lhe davam o ar de alguém que estava realizando magistral e dignamente seu trabalho. O dramaturgo anotava, porém, que ele agia com

\footnotetext{
${ }^{55} \mathrm{O}$ dramaturgo não explicita qual é o Ateneo. Certamente, não poderia se referir ao Ateneo de la Juventud - cujo núcleo era composto por Alfonso Reyes, Antonio Caso, José Vasconcelos e Pedro Henriquez Ureña - , porque este se desfez ainda no período das lutas armadas. No entanto, o relato de Usigli corrobora para observar a organização dos espaços culturais no México pós-revolucionário.
} 
verdade em uma situação falsa; se fosse cobrador, afirmava, certamente estaria conversando com o motorista...

As observações do cotidiano avançam assim para as considerações sobre a história. Usigli critica o excessivo número de heróis criados desde a independência e o que ele chama de "infantilidade de se mantê-los incólumes". Afirma que, com exceção de Morelos, os heróis mexicanos são apenas fragmentos. Sobre a hipocrisia, analisa uma conhecida frase da independência, proferida por Miguel Hidalgo: "Mexicanos: ;Viva México! ¡Mueran los gachupines! ¡Viva Fernando VII!' Como si aquel rey de baraja, ya carcomido en los cuerpos de sus abuelos, hubiera sido un príncipe azteca, un último renuevo del viejo tronco mexica." (TC III, p. 459 - aspas do autor).

Pelos poucos exemplos acima fica expressa a preocupação por desmantelar manifestações culturais e identitárias que ele considerava negativas, através de um enfrentamento crítico, do qual emergiria um teatro nacional. Como demonstração da função edificante, moralizadora e educativa que atribuía à arte teatral, constantemente são estabelecidas relações diretas entre a dramaturgia e a vida cotidiana. Portanto, pode-se inferir que do dia a dia e da historiografia teriam que sair os temas e assuntos a serem transformados em teatro.

Acerca das leituras de Rodolfo Usigli com vistas à criação de um teatro nacional, Luis de Tavira (1996) argumenta que a interpretação do dramaturgo se contrapõe à do próprio México, principalmente naquele contexto. $\mathrm{O}$ autor de tantas obras de temática política pensava em termos de um teatro construído sobre a unidade, a coesão de forças articuladoras do fenômeno (produtores, diretores, patrocinadores, atores, dramaturgos etc.) em um país cujo principal traço constituinte tem sido a diversidade. Tavira (1996) vê essa contradição como algo negativo.

Em nossa perspectiva, o pensamento de Usigli deve ser colocado em sincronia com diversos intérpretes de seu contexto. A perspectiva de uma unidade nacional que negasse a imitação está presente em diversos intelectuais do período, com destaque para José Vasconcelos e Samuel Ramos. Também para esses intérpretes a preocupação com a história tinha uma dimensão significativa. A peculiaridade de Usigli está na forma de abordar esses temas, pois, tendo o teatro como referência, conseguiu elevar os questionamentos sobre o caráter do mexicano ao nível de recursos estéticos da arte a que se dedicava. O tópico a seguir, procura, então, explorar como Usigli utilizou a imaginação e a fantasia, "a faculdade suprema" segundo Vasconcelos (1997, p. 69), para construir um conceito de teatro mexicano. 


\subsection{História e educação no projeto de reforma nacional}

Toda a profundidade do pensamento e da atuação de Rodolfo Usigli poderá ser mais bem compreendida se o inserirmos no contexto histórico em que produziu, sobretudo no período de formação. A palavra-chave que transporta para aquele momento é nacionalismo.

Os autores que se dedicaram à reflexão teórica desse fenômeno sócio-político, conforme destacamos no segundo tópico do primeiro capítulo, enfatizam o papel da educação no processo de afirmação e de construção nacional. No México, a história, a educação e a nação foram os três elementos proeminentes que auxiliaram na consolidação de um projeto modernizador após a Revolução. Os três caminharam de mãos dadas e se manifestaram de maneiras diversas.

Organização em grupos culturais e artísticos, escrita de ensaios e inserção na política ocupam o primeiro plano das maneiras de construir a nação. A título de exemplo, a retomada da trajetória cultural e política de José Vasconcelos (1882-1959) pode contribuir para pontuar a situação dos anos que antecederam a escrita das principais obras usiglianas que dialogam com a história.

Homem de letras no sentido mais amplo da palavra, filósofo e político, Vasconcelos é considerado um dos grandes reformadores da vida cultural mexicana. Tentou democratizar o acesso à cultura e à educação de modo a consolidar um projeto nacional por meio da criação de escolas indígenas e publicação de livros clássicos. Em paralelo às ações como Secretário de Educação Pública ${ }^{56}$, produziu obras que ilustram singularmente o contexto da primeira etapa da história do teatro, dentre as quais se destaca La raza cósmica (1925/1997).

Obra escrita durante uma viagem pelo Brasil, Uruguai, Argentina e Chile, ela desenvolve o conceito (muito fincado em uma linhagem evolucionista e hegeliana da história) de que os povos americanos, sobretudo os de origem portuguesa e espanhola, estariam em processo de evolução para uma nova raça, um novo tipo de homem.

No "Prólogo", Vasconcelos dialoga com a doutrina darwinista e seu uso social por Gobineau, que abordava a problemática da pureza das raças. Porém, o filósofo mexicano não lança mão dessas correntes ideológicas com o intuito de fundamentar sua argumentação. Pelo contrário, reconhece os erros e abusos dessas teorias, inclusive,

\footnotetext{
${ }^{56}$ No México, o cargo de Secretário, em nível federal, corresponde ao de Ministro, no Brasil.
} 
afirma que a primeira guerra mundial teria se originado de um pensamento marcado pela lógica positivista. Por conseguinte, estabelece a necessidade de se construir uma nova dinâmica das relações humanas, marcada não pelo racionalismo, mas pela intuição, pela criatividade, pela fantasia, "la facultad suprema" (1997, p. 69). De acordo com Vasconcelos, essas novas correntes do pensamento, de viés humanístico, tinham nos povos ibero-americanos o melhor exemplo a ser seguido.

Nesse sentido é que a mestiçagem, enquanto ideal, se sobrepõe à pureza e reivindica o direito à igualdade para todos. Esse ponto acrescenta uma premissa ao raciocínio de Vasconcelos: a mistura racial será mais efetiva e igualitária se considerarmos alguns aspectos da modernidade, em especial os meios de comunicação, a educação generalizada e o aumento do nível econômico. Com isso, "irán desapareciendo los obstáculos para la fusión acelerada de las estirpes”. (p. 43).

Quando colocamos essas premissas de Vasconcelos à valorização dos elementos nacionais, inferimos que seu nacionalismo não exalta os elementos identitários nem valoriza a história enquanto monumento. ${ }^{57} \mathrm{O}$ pensador e político mexicano tem uma visão particular tanto da forma como são manipulados os elementos nacionais quanto os da história.

Esta última (que Vasconcelos escreve quase sempre com maiúscula) é um ponto importante no desenvolvimento de sua tese evolucionista de que na América estaria sendo forjada uma "raça cósmica". O filósofo prefere o vocábulo "projeto" para se referir à história. Chamam atenção nesse ponto as considerações metodológicas e os parâmetros em que, para ele, esse conhecimento deve ser adquirido. Inicialmente, Vasconcelos rejeita "la historia empírica, enferma de miopía" e ao mesmo tempo "la historia cientifica". (p. 48). A primeira, falha por não conseguir estabelecer as causas do evento histórico, uma vez que está desejosa do detalhe. A segunda, porque não consegue explicar os eventos para além das reflexões. Detectamos, portanto, que Vasconcelos não acredita numa história especializada, repleta de dados, e que não alcança mais do que uma "microideología del especialista”. Por isso, pensa que "justamente allí donde nada descubre el analista, el sintetizador y el creador se iluminan”. (p. 48).

\footnotetext{
${ }^{57}$ Fundamentamos em Nietzsche (1949) a ideia de um sentimento "monumental" da história. Segundo o filósofo, essa forma de experimentar a história se relaciona com a busca de uma vivência, no presente, das mesmas condições e sensações que se imagina terem vivido os homens em algum momento de esplendor do passado. A história monumental é uma coleção de "efeitos em si", ou seja, "de acontecimientos que, en todos los tiempos, podrán surtir efecto”. (NIETZSCHE, p. 101).
} 
Se a história não deve se restringir aos especialistas, o nacionalismo tampouco deve ficar restrito à exaltação dos interesses materiais e morais da pátria. Vasconcelos reconhece a necessidade da existência de um pensamento patriótico, mas incentiva que esse patriotismo ${ }^{58}$ busque finalidades mais "vastas y transcendentales" (p. 52). Ele acreditava que o tipo de nacionalismo assumido por seu país deveria ser diferente daquele que teria conformado o processo de independência dos Estados Unidos, por exemplo.

Para entender como o nacionalismo do século anterior instigou mais a valorização do "saxão" (Vasconcelos não escreve Estados Unidos), devemos saber que o autor parte do princípio de que sua época (entendamos a Modernidade) continuava sendo, uma luta entre "latinos" e "saxões", visão já iniciada, entre outros, pelo cubano José Martí (1853-1895). Nessa batalha, os povos hispano-luso-americanos tenderiam a se enfraquecer devido à sua incapacidade de união e ao rompimento com os povos/nações que lhes deram origem. O pior motivo, porém, era a vinculação com os povos saxões. Daí a afirmação de que "nosotros no seremos grandes mientras el español de América no se sienta tan español como los hijos de España.” (p. 51).

Nesse sentido, La raza cósmica apresenta uma visão otimista do futuro, mesmo reconhecendo falhas e desvios do presente em que foi escrito. Esse otimismo expõe mecanismos intuitivos de raciocínio, temperados aqui e ali com doses de conhecimento científico. Assim, ao longo do texto, desenham-se os motivos que conduzirão à superioridade da raça ibero-americana.

Apesar de rejeitar muitos aspectos das teorias darwinistas e comtianas, todo o capítulo III, por exemplo, desenvolve-se a partir da ideia de melhoramento da raça. Vasconcelos acredita que na "raça" ibero-americana desaparecerão as uniões entre indivíduos "feios" e "miseráveis" e a beleza e a vontade de abandonar aspectos degradantes conduzirão as uniões. Em um segundo estágio de desenvolvimento, geração após geração, o aspecto físico será substituído pelo desejo de uma união baseada nas qualidades que os indivíduos de uma nação queiram tornar predominantes do ponto de vista moral, ético e estético.

Interessante notar como se produziria essa mudança:

Las razas inferiores, al educarse, se harían menos prolíficas, y los mejores especímenes irán ascendiendo en una escala de mejoramiento

\footnotetext{
${ }^{58}$ Neste parágrafo, "nacionalismo" e "patriotismo" aparecem como sinônimos, uma vez que parece não haver distinção para o pensador. Estamos cientes, no entanto, de que os termos têm designações diferentes nas Ciências Humanas contemporâneas.
} 
étnico, cuyo tipo máximo no es precisamente el blanco, sino esa nueva raza a la que el mismo blanco tendrá que aspirar con el objeto de conquistar la síntesis. (p. 72).

O excerto reforça a tese do livro, mas o que interessa frisar aqui o papel da educação como parte desse processo. Educação do espírito para ascender ao estágio superior da humanidade. Portanto, entre a herança de concepções ainda enraizadas no século XIX e uma prospecção baseada num projeto educacional, a nação, para Vasconcelos, foi entendida a partir da história.

Além desse intelectual, outro pensador desse contexto que também contribuiu profundamente para forjar um pensamento nacionalista cujos ecos se farão ouvir em muitos dramas do período - e até mesmo posteriormente - é Samuel Ramos, autor de $E l$ perfil del hombre y la cultura en México. Publicado em 1934, é um estudo da "caracterología" do mexicano e da filosofia da cultura, conforme explica na terceira edição, quando pretende dissipar as primeiras impressões da crítica, que via no livro uma interpretação psicanalítica da sociedade. Apesar de realmente haver um apoio na psicanálise, sobretudo com o discípulo de Freud, Alfredo Adler, segundo Ramos, a motivação para escrever a obra foi a vontade de empreender uma teoria que explicasse as modalidades específicas do mexicano e sua cultura. Chama atenção, mais uma vez, como se recorre à história para apoiar as conclusões.

Seguramente a interpretação da crítica fazia sentido porque, dentre as diversas características mostradas por Ramos, a mais impactante foi construída em torno de um conceito psicanalítico, o sentimento de inferioridade, que baliza todo o ensaio. As análises culturais e históricas baseiam-se nele e dele surgem as elaborações para o futuro do México.

$\mathrm{Na}$ leitura que Ramos faz de Adler, a inferioridade manifesta-se em indivíduos que têm uma preocupação exagerada por afirmar sua personalidade, "que se interesan vivamente por todas las cosas o situaciones que significan poder, y que tienen el afán inmoderado de predominar, de ser en todo los primeros" (RAMOS, 2001, p. 51). Do descompasso entre aquilo que se é e aquilo que se deseja ser, surge o sentimento de inferioridade. As explicações desse fenômeno, tanto nos indivíduos quanto nas sociedades, seriam históricas. As implicações, por outro lado, impediriam que exista realmente um "avanço histórico".

Demonstrando ainda uma perspectiva fundada no positivismo (lembremo-nos de que as teses com que Ferdinand Braudel mudaria a epistemologia da historiografia 
foram lançadas apenas em 1949), a história deveria apresentar uma concatenação lógica dos eventos, de modo a haver um "avanço", em que cada novo fato seria um episódio da narrativa. A história mexicana, ao contrário, teria produzido sempre o retorno das mesmas figuras. Nos termos usados por Ramos, essa repetição e constante revalorização das mesmas figuras, produzia uma anti-história. Diz ele que "el círculo vicioso que acabamos de diferenciar en la masa de nuestro pasado constituye, pues, un elemento más bien antihistórico, un obstáculo que ha retardado la acción de las fuerzas históricas positivas." (p. 27). O círculo a que Ramos se refere são os processos de Independência e Reforma, os quais não teriam constituído momentos da história, mas derivações da vontade de emancipação da Espanha.

Esse mesmo desejo que impulsionou os dois principais momentos da história mexicana teria projetado, nos cidadãos das primeiras décadas do século $\mathrm{XX}$, o sentimento de inferioridade, cuja origem estaria na Conquista e na Colonização, apesar de se manifestarem ostensivamente na Independência. A ambição de se libertar da Espanha não significava ser outra sociedade, outra nação, mas sim ser alguém igual ao modelo. Nas palavras do próprio Ramos,

siendo todavía un país muy joven, quiso, en un salto, ponerse a la altura de la vieja civilización europea y, entonces, estalló el conflicto entre lo que se quiere y lo que se puede. La solución consistió en imitar a Europa, sus ideas, sus instituciones, creando así ciertas ficciones colectivas que, al ser tomadas por nosotros como un hecho, han resuelto el conflicto psicológico de un modo artificial. (p. 15).

Em consonância com os pressupostos éticos e morais de Usigli, na visão de Ramos, o processo de imitação tinha implicações no convívio cotidiano do mexicano. Mentira e ficção, vontade de dominação, ilusão de que é possível se impor pela força, todos esses aspectos eram mencionados a partir da figura do pelado. Arquétipo cultural extremo na análise de Ramos, o pelado é descrito como alguém que age de maneira agressiva para poder afirmar aquilo que não é. Sua linguagem está repleta de jargões machistas. É um homem que tem "muchos huevos"; que pensa "ser el padre"; que, frente a um cidadão europeu ou estadunidense, orgulha-se de que no México todos são "muy hombres", apesar de não possuir ciência, técnica, arte. (p. 55-56). Não é difícil identificar que predomina nessa visão uma percepção fisiológica do machismo, ou como o próprio Ramos escreve, "zoológica". A agressividade tem a função de encobrir o sentimento de inferioridade. Para o pelado, a valentia seria a marca do mexicano. Por isso, para Ramos, o pelado é o elo simbólico que associa nacionalidade e virilidade. 
A seguir, o filósofo oferece uma série de propostas para que o mexicano transforme sua "natureza", marcada pela suscetibilidade, pela mentira, pela imitação e pelo machismo. Aqui novamente há proximidade das ideias de Samuel Ramos com as de Usigli, pois como corolário desse sentimento negativo que é a imitação, o pensador expressa que "la virtud que más urgentemente hay que aconsejar al mexicano actual, es la sinceridad, para que arranque el disfraz con que se oculta a sí mismo su ser auténtico." (p. 67).

Nesse conselho residem dois importantes aspectos da arquitetura conceitual de autor: a forma de entender o nacionalismo e o papel da educação no processo de construção nacional. Ele mostra que até a primeira década do século XX, seu país sempre dirigia o olhar para a Europa a fim de encontrar parâmetros culturais, científicos e educacionais. Com a ação de José Vasconcelos e o sentimento de decepção com a Europa que se exterminava em guerra, os mexicanos teriam se voltado para seu interior. A década de 20 apresenta-se, então, como o momento específico para uma imersão nas tradições e nas heranças indígenas. Para Ramos a razão para essa mudança seria biológica. Ele, inclusive, fala em um “despertar de la conciencia del 'yo' nacional”. (p. 85). Esse processo faz parte do fenômeno da imitação. Por outro lado, o despertar da consciência surge não em decorrência da imitação, mas da desilusão com o modelo imitado. Ramos (p. 85) trata a questão em termos de fracasso: “El fracaso de múltiples tentativas de imitar sin discernimiento una civilización extranjera, nos ha enseñado con dolor que tenemos un carácter propio y un destino singular, que no es posible seguir desconociendo."

A “expressão nacional” que ele defende, então, não é um enraizamento, a volta a uma era de ouro da cultura mexicana que desconsidere os elementos europeus que deixaram sua cota para formar a nação. A incorporação das culturas, inclusive das clássicas, assim como fizeram os integrantes do Ateneo de la Juventud, parecia o caminho ideal a percorrer. Por isso, não se poderia mais admitir praticar um europeísmo falso nem exaltar um também falso mexicanismo: "Para volver la espalda a Europa, México se ha acogido al nacionalismo... que es una idea europea." (p. 85).

É nesse ponto que o vínculo entre história e educação tomam a dianteira do processo de construção nacional. Ramos exprime que seria necessária uma educação orientada ao desenvolvimento da cultura, cujo fim último recairia no ser humano. Porém, lamenta que até aquele momento não houvesse um intelectual com capacidade e conhecimento suficientes para apresentar uma visão histórica que conseguisse dissolver as contradições e organizar o caos em que estava imersa a cultura naqueles momentos. 
Nesse sentido, Ramos se apoia nas ideias de Justo Sierra, admirado por ser, ao lado de Vasconcelos, um dos grandes pensadores cujo sentimento nacional tinha se erguido também a partir da educação. Na frase retirada de La evolución política del pueblo mexicano (originalmente publicado em 1902), fica clara a perspectiva de que a verdadeira educação seria aquela que oferecesse acesso a toda forma de cultura, que "se propusiera adquirir los medios de nacionalizar la ciencia, de mexicanizar el saber" (apud RAMOS, 2001, p. 115).

Sua proposta de uma educação humanista surge, então, como o melhor caminho para se promover o autoconhecimento, eliminar o sentimento de inferioridade e praticar, na vida cotidiana e na governança política, a sinceridade. Aos olhos do leitor do século XXI a "solução" de Ramos apresenta-se um tanto quanto simplória. No entanto, a educação com princípios humanistas correspondia adequadamente ao contexto mundial em que ele vivia. Se hoje sabemos que a promoção de bases educacionais exige uma alta complexidade de articulação entre vontade política, conhecimentos técnicos e humanísticos, e entre ciência e arte, para um país que fizera da violência o meio de libertação, o desejo de edificar um novo humanismo não era uma empreitada desprezível.

\subsection{Manipulando e escrevendo a história}

Na leitura da produção de Rodolfo Usigli, privilegiaremos a análise da Trilogia das Coroas: Corona de sombra (1943), Corona de fuego (1960) e Corona de luz (1963), apesar de ele ter trabalhado com eventos históricos em outras obras também. Não poderíamos deixar de examinar, por exemplo, aspectos sobressalientes de El gesticulador $(1938)^{59}$, porquanto, além de questionar o evento histórico da Revolução, essa peça lança mão de recursos cênicos de grande monta tanto para a dramaturgia do autor, quanto para seus sucessores diretos e indiretos. Rodolfo Usigli classificou-a apenas como "pieza", pelo qual não era considerada anti-histórica. A semelhança entre as obras da trilogia e esta última está na tentativa de desvelar as mentiras com que a historiografia oficial é construída.

Convém aqui revisar o conceito de anti-história, segundo Usigli. Construir uma peça anti-histórica, como sinalizamos no capítulo 2.3., não significava negar os fatos

\footnotetext{
${ }^{59}$ As datas entre parênteses neste parágrafo referem-se à primeira aparição das peças, seja pela edição seja pela montagem.
} 
consagrados pela historiografia. $\mathrm{Na}$ verdade, para o autor a liberdade de promover deslocamentos na cronologia atendia à "verdade dramática", ou seja, a história tinha que estar em função do que é contado no palco e das necessidades exigidas pela ação, ainda que para isso precisasse haver algumas inconsistências entre o que registram os documentos e a cena do palco. Pelas palavras do próprio autor, ou teatro ou história devem prevalecer quando um tema histórico sobe ao palco: "nadie puede servir a un tiempo al teatro y a la historia." (USIGLI, 1985, p. 33). Esse princípio lhe provocou inúmeras críticas. No entanto, ele sempre se mostrou bastante consciente dos deslocamentos que causava. Os prólogos à Corona de luz, às "Notas a Corona de fuego" e o "Prólogo después de la obra" à Corona de sombra, bem como os diversos artigos rebatendo as críticas a El gesticulador não deixam a menor dúvida de que Usigli conhecia muito bem a história que utilizava como matéria-prima da arquitetura de suas obras.

Aliás, o excessivo número de paratextos ensaísticos sobre as peças causa dificuldades ao estudioso da obra usigliana que opte por verificar as inconsistências, pois nos textos mencionados acima o dramaturgo expõe, de maneira muito clara e didática, o conhecimento historiográfico e os recortes que realiza em suas peças. Suas explicações que a interpretação das obras ultrapasse a busca pela identificação de similaridades entre evento e recriação literária. Além disso, apontam para a confirmação de nossa tese sobre a emergência da ficcionalidade como consequência da reflexão sobre a história e da intertextualidade com a historiografia.

Com efeito, isso nos leva a refletir sobre outros recursos que conformam a arquitetura das peças anti-históricas, incluindo El gesticulador. Dentre eles, sem dúvida, está a inserção de personagens que, na história, foram responsáveis pelo registro de eventos de seu tempo. A recorrência, nas peças anti-históricas, a historiadores, cronistas e criadores de autos sacramentais instiga a pensar que outros interesses teriam motivado a elaboração da ação dramática. Essa recorrência não nos parece fortuita.

Por isso, nosso primeiro objetivo neste momento é realizar uma leitura de $E l$ gesticulador, enfatizando a hipocrisia, outro dos conceitos-chave, e sua potência metateatral que impactaria a criação das obras anti-históricas propriamente ditas. A seguir, vamos nos debruçar sobre duas peças da trilogia com vistas a perceber a inserção de personagens responsáveis pelo registro histórico como um dos principais recursos de que o dramaturgo lança mão para construir seus dramas. Corona de fuego, a segunda da trilogia, tem leitura paralela com as peças de Vicente Leñero e Sabina Berman sobre a conquista do México. 


\subsubsection{El gesticulador}

Nessa obra, talvez uma das mais instigantes e famosas de Usigli ${ }^{60}$, a conjunção do ficcional e do histórico ganha dimensão de autorreflixividade. Antes de dar forma ao que designaria de anti-história, foi na imersão de um evento contemporâneo, de passado recente, que ele encontrou a chave de sua dramaturgia e desenhou em grandes traços a modernidade da dramaturgia mexicana. A partir daí abriu-se o caminho para este que vem a ser o eixo de nosso estudo: a história e a historiografia enquanto elementos aglutinadores da dramaturgia mexicana em um período que comporta ao menos três momentos da trajetória da arte dramática no século XX. Com El gesticulador, mais do que uma ressignificação da Revolução Mexicana e seus desdobramentos na vida política ulterior ao movimento armado, estamos diante da posta em marcha de uma série de procedimentos cênicos que parecem ter sido pouco observados pela crítica.

Levada ao palco pela primeira vez apenas em 1947 durante o regime de Miguel Alemán Valdés (presidente de 1946 a 1952), o impacto dessa obra no horizonte político é bem conhecido. Ortiz Bullé-Goyri (2012, p. 8) informa, por exemplo, que Salvador Novo (desavença pública e notória de Usigli) e Xavier Villaurrutia (que junto do anterior estava entre os autores dramáticos mais respeitados daquele momento) se opuseram à obra, acusando Usigli de ser inimigo da Revolução. Por Beardsell, sabemos também que

Aquí se encontraba un dramaturgo nacional que no sólo estaba ilustrando las características de la vida mexicana, sino que cuestionaba la imagen oficial de la Revolución y censuraba flagrantemente las contradicciones políticas de la clase gobernante contemporánea. (2002, p. 15)

Por sua vez, Argentina Casas de Usigli, a segunda esposa do dramaturgo, conta que

Hasta ese momento nadie se había atrevido a criticar nuestra política y a nuestros políticos y sobre todo la corrupción en la política, por lo que se oía hablar de ella en los cines, en los mercados y hasta entre los marchantes de las verduras que ya habían ido a verla. En los periódicos se publicaban caricaturas del mundo político y a muchos les colgaron el letrero de Gesticuladores. (2014, s/p).

\footnotetext{
${ }^{60}$ Dentre os artigos que analisa as montagens e adaptações dessa obra usigliana, indicamos o de Alejandro Ortiz Bullé-Goyri, "El gesticulador para gesticuladores: entre el escenario y la pantalla" (2012), em que se comentam as encenações realizadas a propósito dos cem anos da Revolução. O crítico destaca que todas foram feitas por grupos privados, ou seja, a obra não foi contemplada nos festejos oficiais.
} 
Podemos ter uma dimensão do incômodo causado pelos ardis do protagonista César Rubio, pois a obra escrita em 1938, publicada em 1943 na revista El Hijo Pródigo, embora encenada pela primeira vez quase uma década depois de composta, estreou no dia 21 de maio, no Palacio de Bellas Artes, em meio à programação do recém-inaugurado Instituto Nacional de Bellas Artes (INBA), criado com a finalidade de incentivar a arte nacional. ${ }^{61}$ A temporada de maio de 1947, com peças de Xavier Villaurrutia, Agustín Lazo e Francisco Monterde, os dois últimos bem reconhecidos pela criação de obras com tendência à exaltação nacional, fora elaborada com vistas a dar força, simultaneamente, ao teatro e ao governo.

O impacto político tão enfatizado pela crítica deve ser visto ao lado do choque estético, pois, segundo Beardsell (2002, p. 24), dois recursos dramatúrgicos que fundamentam a criação de Usigli eram também um ruído para a época:

Uno era una cuestión de integridad estética: la elección de una forma que correspondía tanto a la idea como a la anécdota. [...] Por finos que fueran el diálogo, las escenas o los personajes, estos elementos no servían sin una estructura coherente en su conjunto. El otro era una cuidadosa atención a la relación entre los acontecimientos sobre el escenario y la actitud de quienes estaban observando. Lograr la participación del público de alguna manera era un propósito crítico del dramaturgo.

Com efeito, apropriando-nos das palavras de Lionel Abel (1968) ${ }^{62}$ sobre Hamlet e La vida es sueño, poderíamos dizer que pouco se tem observado em El gesticulador como a construção da mentira de César Rubio corresponde a uma encenação teatral. Queremos, portanto, descobrir cenas em que Usigli tenha projetado essa construção com vistas a efetivar, no palco, a metateatralidade de seus pressupostos ideológicos e estéticos. Move-nos a curiosidade por saber em que medida a estruturação dramática, os recursos de progressão da trama e a construção do caráter das personagens servem ou não de procedimentos metateatrais capazes de abrir sendas para a elaboração de outras obras, tanto de Usigli mesmo quanto de outros autores que compõem nossa pesquisa.

\footnotetext{
${ }^{61}$ A direção foi de Alfredo Gomez de la Vega e a cenografia de Antonio Ruiz. O cartaz da estreia anunciava que se tratava de uma "grande" criação do diretor a montagem de uma obra "sensacional".

62 “[...] não tem sido notado [...] que são raríssimas as cenas, em toda a obra, nas quais algum personagem não esteja tentando dramatizar outro. Quase todos os personagens importantes agem em um momento ou outro como um autor dramático, utilizando a conscientização do drama que tem o dramaturgo para impor determinada postura ou atitude a algum outro" (ABEL, 1968, p. 69).
} 
A rigor, não se trata de uma obra histórica, no sentido com que deslindamos o escopo de nossa pesquisa. Os referentes históricos, personagens, ambiente e conflito, sobretudo, pairam mais no imaginário do que nos registros documentais. $\mathrm{O}$ evento que sustenta o pano de fundo, a Revolução, era ainda recente quando Usigli a escreveu, apesar de que já haviam se passado três décadas. Mesmo na estreia ainda ecoavam os conflitos e os discursos de exaltação do movimento, embora no plano intelectual possamos hoje identificar algumas críticas já naquele momento.

El gesticulador apoia-se em dicotomias. Verdade e mentira ocupam certamente o primeiro plano, mas realidade e ilusão e história e ficcionalidade estão também presentes a todo instante. A primeira dessas dicotomias faz parte da linha principal da trama. As outras duas se tornam palpáveis à medida que caminhamos rumo à teatralidade dentro da própria obra e da história.

A peça se divide em três atos, bem delimitados do ponto de vista do enredo. As cenas, porém, não são marcadas explicitamente. Percebemos que o autor faz a ilação dos episódios por meio da alternância de personagens que agem no proscênio, com suas entradas e saídas.

O primeiro ato mostra a situação da família de César Rubio, historiador e professor universitário na capital, que retorna à sua cidade de origem, no Norte do país, para ver se conseguirá dar condições melhores de vida a seus filhos e esposa. Todo o cenário é pensado para revelar que eles vivem em dificuldades financeiras e estão imersos em uma atmosfera de desânimo e frustração. Os filhos sentem-se descontentes porque abandonaram a capital e a esposa, frustrada porque não tem esperança de melhorar de vida.

Em meio às decepções de Miguel — jovem universitário bastante engajado nas greves da universidade onde o pai lecionava - e de Julia — moça sonhadora e plena de ingênuos sentimentos amorosos, que almeja ter uma vida de boas aparências —, um acaso ilumina a possibilidade de mudanças nos destinos da vida profissional e familiar de César Rubio. É a chegada de Oliver Bolton. Professor de história latino-americana em Harvard, devido a problemas mecânicos no carro, pede auxílio na residência dos Rubio. Explica ao anfitrião que está sob a incumbência de descobrir documentos inéditos acerca da Revolução Mexicana. Seu principal objetivo é descobrir o paradeiro de ou os rumos tomados por um ex-general considerado o maior de todos os líderes: César Rubio. Desaparecido precocemente nos albores do conflito armado, no imaginário das personagens, se tratava de "un hombre extraordinario. Un general mexicano joven, el 
más grande revolucionario, que inició la revolución en el Norte, hizo comprender a Madero la necesidad de una revolución, dominó a Villa.” (TC I, p. 739-740).

A homonímia entre o historiador mexicano e a personagem que no plano ficcional é apresentada como histórica instaura a confusão motivadora da ação no segundo ato, pois Rubio induz o norte-americano a acreditar que ambos são a mesma pessoa. $\mathrm{O}$ ato de gesticular se revela na opção de César por não chegar a afirmar nem tampouco negar o que Bolton inferiu.

Oliver Bolton regressa aos Estados Unidos depois de comprar, do dono da casa, uma série de documentos comprobatórios da história do César Rubio revolucionário, todos verdadeiros, porquanto o historiador mexicano realmente as possuía. Antes, porém, o Rubio intelectual faz um pacto de não revelar a origem dos documentos nem a localização de seu "objeto de estudo".

Quatro semanas depois, o jornal local noticia que Oliver Bolton publicou no New York Times artigos sobre o ex-combatente até então tido como morto pelo regime oficial. No artigo, o historiador norte-americano, contudo, quebra o pacto e anuncia que César Rubio ainda vive em uma humilde casa em sua terra natal e que é professor universitário. Enfim, declara a fidedignidade de suas descobertas tanto por meio dos documentos quanto por ter visto o pesquisado em campo.

A notícia impulsiona a busca de políticos do Partido Revolucionario de la Nación (PRN) ${ }^{63}$ por César Rubio com o intuito de transformá-lo em candidato a governador. Novamente, ele não desfaz a mentira e, de novo, encontra a possibilidade de mudar de vida. ${ }^{64}$

No entanto, no último ato, seu principal adversário político, Navarro, pede uma conversa em particular a fim de fazer César Rubio desistir da eleição, pois sabe que se trata de uma fraude. Sua certeza decorre do fato de ter sido ele o assassino do verdadeiro Rubio.

No desfecho, como a desistência não acontece, Navarro trama o assassinato de seu oponente. Manda matá-lo e atribui o ato a um cristão que não queria ver realizados definitivamente os ideais revolucionários.

\footnotetext{
${ }^{63}$ Jogo claro com a sigla do Partido Nacional Revolucionário, PNR, criado por Plutarco Elías Calles em 1929, que se modificou em 1938 para Partido da Revolução Mexicana, PRM, e célula embrionária do que viria a ser, em 1946, o PRI.

${ }^{64}$ Cabe apontar que a troca de identidades da maneira como se concebe em El gesticulador parece resgatar um procedimento típico do teatro de costumes e que remete aos clássicos de Juan Ruiz de Alarcón e de Moliére. A "novidade" reside no tom de denúncia não da moral subjetiva, mas da política em determinado momento específico.
} 
Ao longo dessa trama repleta de peripécias, o conhecimento da verdade é quase uma obsessão. Miguel, o filho de Rubio, é a personagem que empreende essa busca de maneira mais contundente. Suas ideias opõem-se às de seu pai desde os dias da universidade. Ele representa a mentalidade que paulatinamente vinha se formando, nos anos 40, a respeito das consequências políticas dos governos revolucionários. Embora no plano histórico a mudança tenha ocorrido mais lentamente, na peça, Miguel, já no primeiro ato, funciona como um elemento propagador das convicções de que a verdade sobre os usos que, até então, os políticos faziam da Revolução precisava ser revelada. A partir do âmbito familiar, o ex-estudante critica as mentiras: "Quiero vivir la verdad porque estoy harto de apariencias" (p. 731); "Es la apariencia, la mentira que me hace sentirme asi'” (p. 732); “No quiero seguir viviendo en la mentira” (p. 738) são frases emitidas por um jovem com intenso fastio da vida familiar. ${ }^{65}$ Ao mesmo tempo, possui frases prontas, denunciando uma contradição típica do jovem em processo de amadurecimento e formação: “ ¿No te das cuenta de que quiero la verdad para vivir; de que tengo hambre y sed de verdad; de que no puedo respirar ya en esta atmófesra de mentira?” (p. 790) são palavras direcionadas à mãe depois de descobrir que seu pai não é o César Rubio da Revolução. Tais palavras, pela simplicidade, possuem um tom mais brando, se comparadas às duras queixas do início da trama:

MIGUEL. - [...] Cuando llegaba tu santo, mamá, y venían invitados, las sillas y los cubiertos eran prestados todos, porque había que proteger la buena reputación de la familia de un profesor universitario... y lo que se bebía y se comía era fiado, pero iqué pensarían las gentes si no hubiera habido de beber y de comer!

ELENA. - Miguel, no tienes derecho a reprocharnos el ser pobres. Tu padre ha trabajado siempre para ti.

MIGUEL. - ¡Pero si no es el ser pobres lo que les reprocho! [...] jera cómico porque no engañaban a nadie... ni a los invitados que iban a sentarse en sus propias sillas, a comer con sus propios cubiertos... ni al tendero que nos fiaba las mercancías! Todo el mundo lo sabía, y si no se reían de ustedes era porque ellos vivían igual y hacían lo mismo. (p. 732).

Da mesma maneira que a obsessão de Miguel pela verdade delata uma atitude quase cômica por causa de sua ingenuidade, a mesma ideia fixa de Bolton para que o

\footnotetext{
${ }^{65}$ La familia cena en casa é um dos títulos que Usigli deu a uma peça cujo teor de crítica à política também é muito forte. Nessa obra, pode ser observado um conflito entre os elementos internos e externos da cultura nacional. Para o autor, não obstante as divergências externas, o importante era que a família "jantasse em casa", isto é, que os conflitos internos fossem apaziguados sem a intervenção de países estrangeiros. Observamos, portanto, que a família de Miguel funciona como um microcosmo da forma como Rodolfo Usigli via o México. Não obstante os ímpetos de infantilidade do filho de Rubio, suas palavras devem ser interpretadas tendo-se em conta a capacidade reveladora dos questionamentos que pouco a pouco adquiriram as reflexões de historiadores e intelectuais em geral.
} 
paradeiro de César Rubio seja "lógica" produz um efeito sarcástico. No diálogo em que os historiadores acordam a negociação dos documentos em poder do mexicano, Bolton insiste em que "la historia no es una novela" (p. 746), pois "la verdad siempre es lógica" (p. 745). Para o norte-americano, a verdade sobre o desaparecimento do general César Rubio deveria ser condizente com o caráter íntegro, extraordinário de um homem que era "el amo de la revolución" (p. 744). O professor de Harvard ainda almeja que a história contada pelo anfitrião faça sentido, sentido lógico, porquanto possui responsabilidades com seus estudantes, que pagam para aprender. Essa ética, porém, não predomina, uma vez que quando publica os artigos no New York Times não mantém a palavra.

Todo o diálogo de Rubio e Bolton é construído sobre a sugestão, como se o referente tivesse que ser, a todo instante, apenas posto nas entrelinhas ou deixado em subtexto. Ardiloso, o historiador mexicano conduz seu interlocutor à conclusão lógica que espera. Ainda em meio às negociações e à revelação dos fatos passados, César consegue apresentar uma verdade lógica e satisfatória para Bolton, mas fortemente enraizada na maneira de conduzir a história de seu país:

CÉSAR. - Se apartó de la revolución completamente desilusionado, y pobre.

BOLTON. - (Con ansiedad.) ;Pero vive!

CÉSAR. - (Acentuando su sonrisa.) Vive. Más que nosotros dos.

[...]

BOLTON. - ¿Qué ha hecho desde que desapareció? Su carácter no es para la inactividad.

CESAR. - No.

BOLTON. — ¿Pudo dejar de ser un revolucionario?

$[\ldots]$

CÉSAR. - Habia otras cosas que hacer... había que continuar la revolución, limpiarla de las lacras personales de sus hombres... [...] Ser, en apariencia, un hombre cualquiera... un hombre como usted... o como yo... un profesor de historia de la revolución, por ejemplo.

(p. 746-747)

A condução mentirosa da história: essa é a crítica tão constante que se realiza em César Rubio. Com efeito, a verdade, enquanto tema das personagens Miguel e Oliver Bolton, no primeiro ato, se constrói como uma encenação. Bolton é envolvido em uma trama, converte-se em personagem de uma farsa de cuja realidade parece impossível duvidar porque está ancorada em documentos. Além disso, é uma verdade que ele almeja conhecer. De certa maneira, ambos os historiadores procuram escrever, dar sentido à história de maneira diferente. Enquanto o primeiro cria uma nova versão dos eventos, o segundo acredita nela sem nenhum questionamento das fontes. Assim, pensa estar descobrindo aos poucos a versão 
sobre o caudillo a partir da intimidade doméstica do professor homônimo. Trata-se, porém, de uma versão equivocada, sem base na pesquisa séria das fontes.

Dessa forma, nas últimas cenas do primeiro ato, o tema da mentira articulado à encenação teatral se conjuga de modo tão original que podemos dizer que existe ali um recurso do teatro no teatro. Enquanto Rubio envolve o norte-americano na farsa - e Bolton se deixa envolver - Elena passa, silenciosamente, da cozinha para a sala - e vice-versa. Ao fim, depois que o marido sugere ser o homônimo, fica "sin gestos", incapaz de intervir na história que se desenvolve na sua frente e da qual se transforma em espectadora. A movimentação de Elena parece colocá-la entre dois mundos: o da realidade, a cozinha, e o da ficção, a sala, onde estão as personagens Oliver e César.

A busca pela verdade preocupa também as personagens secundárias. Os políticos locais, Epigmenio Guzmán, Estrella, Salinas, Garza e Treviño empenham-se em saber a identidade verdadeira de Rubio, oscilando entre a desconfiança e a esperança de que o historiador seja realmente o ex-combatente. A entrada dessas personagens impacta pela imediatez da pergunta à queima roupa: “ ¿Es usted el que dice ser el general César Rubio?" (p. 758). A seguir, todo o jogo da cena se constrói sobre a ambiguidade das palavras de Rubio, que, mais uma vez sem negar direta e explicitamente que não é quem eles procuram, prefere, em vez disso, cultivar a dubiedade:

ESTRELLA. - [...] ¿Qué tiene usted que decir, señor Rubio? Debo pedirle que no se equivoque sobre nuestras intenciones, que son cordiales.

CÉSAR. - (Pausado, sintiendo como una quemadura la mirada fija de Miguel.) Todos ustedes son muy jóvenes, señores... pertenecen a la revolución de hoy. No puedo esperar, por lo tanto, que me reconozcan He dicho ya que soy César Rubio. ¿Es todo lo que desean saber?

$\mathrm{Na}$ verdade, o historiador sabe das intenções dos políticos, reconhece as implicações do que pode acontecer de bom para si mesmo e sua família caso aceite o convite para ser candidato a governador, por isso prefere jogar. Frente às exigências de que dê provas de ser César Rubio, responde com outras perguntas, uma estratégia típica do discurso argumentativo de envolver os interlocutores — incluindo seu filho: "Es curioso que quienes necesitan de pruebas materiales sean precisamente mis paisanos, los diputados locales... (mirada a Miguel)... y mi hijo. (Miguel retrocede un paso, bajando la cabeza.) ¿Por qué no me dejan tan muerto como estaba?” (p. 761). 
A inquirição dos políticos para confirmar a identidade de César Rubio prossegue. Agora, Guzmán, até então em silêncio, propõe que o dono da residência olhe a fotografia que está acoplada a um relógio de bolso. César dá informações precisas e fidedignas da pessoa registrada no retrato. É o pai de Guzmán, chamado Gallareta, cuja morte decorreu da tentativa de proteger César Rubio. Nesse instante, o interrogado passa a falar em terceira pessoa. Seu discurso assume o tom de um historiador dos tempos modernos e não mais o de uma testemunha ocular da história:

GUZMÁN. - (Más entusiasmado.) iYa lo creo! Ese era el viejo... murió peleando. Valiente de la escuela de usted, mi general. CÉSAR. - ¿De cuál de las dos? (Risas.) No... la Gallareta murió por salvar a César Rubio. Cuando los federales dispararon sobre César, que iba adelante a caballo, el coronel Guzmán hizo reparar su montura y se atravesó. Lo mataron, pero se salvó César Rubio.

(p. 763).

Treviño percebe a mudança de referencialidade no discurso, questiona os motivos dela. César, “cada vez más dueño de sí”, aprofunda a ambiguidade, com palavras cada vez mais vagas. Inclusive, o texto que reproduz na resposta se enche de reticências: "Han pasado muchos años... los hombres se transforman. Luego, la costumbre de la cátedra..." (p. 763).

A dicotomia verdade / mentira (ou história e ficcionalidade) arquitetada pelo procedimento metateatral extrapola o ambiente da comunicação entre as personagens e acontece também entre autor e leitor. O processo de elaboração e aceitação da mentira alcança a própria voz autoral. A didascália, essa espécie de régua que é, tradicionalmente, capaz de delatar os limites do ficcional no texto dramático, também é corrompida pelo jogo de Rubio. Três são as indicações de que isso acontece.

Num primeiro momento, o protagonista manifesta a intenção de se afastar dos políticos: "Me alejaré para siempre de la política. Prefiero continuar mi vida humilde y oscura de hasta ahora." (p. 765), ou seja, há uma forma narrativa e não a injuntiva, que é mais comum. A didascália, porém, nos informa que essas palavras foram ditas "Involuntariamente en papel, viviendo ya el mito de César Rubio" (p. 765). A modéstia e a humildade manifestadas aos políticos estão em desacordo com o que a personagem deseja na verdade. Nesse jogo entre a voz da personagem e a didascálica explicita-se o tom didático e de denúncia que envolve toda a obra, pois a oposição das vozes em disputa provoca o desvelamento das intenções da personagem. 
Em outro ponto da insistente tentativa de convencer Rubio a se candidatar, a peculiaridade está na participação da filha e da esposa de César. Julia, que vê a oportunidade de possuir uma vida de luxo, incentiva o pai a aceitar. Já Elena, que está contente por acreditar que o esposo não vai ceder, o toma pelas mãos. Ele sorri, e a didascália explica que "sería difícil decir por qué." (p. 766). O sorriso de César para ela a partir do aperto de mão é muito ambíguo: ao mesmo tempo em que comunica à mulher a recusa, para o espectador e os leitores esse gesto pode ser dúbio.

Finalmente, mais uma vez em meio aos argumentos de César para negar a candidatura, a voz didascálica enfatiza o intuito de criar, na leitura, um efeito de sentido semelhante ao que se espera alcançar no palco, isto é, a denúncia das fraudes produzidas no e pelo sistema político: "Esto [el regreso a la tierra natal hace solamente cuatro semanas] lo dice con un tono definitivo, casi triunfal. Sin embargo, sería difícil precisar qué objeto es el que persigue ahora." (p. 768).

Esses comentários, que fazem a mediação entre a ficcionalidade da representação e a "verdade" da escrita dramatúrgica, possuem uma progressão que vai da manifestação ponderada da dissimulação de César Rubio até a certeza de que o historiador teria conseguido, inclusive, fazer com que a própria voz didascálica se sentisse insegura. Nessas rubricas, mais do que indicar o movimento, o gesto, o tom etc., existe um procedimento metateatral atípico, porque não se joga com a ilusão apenas no plano cênico. A estratégia ficcional que melhor poderia explicar essa tentativa de mostrar ao leitor o quanto a história e a política podem ludibriar as pessoas vincula-se a outros recursos narrativos que vez por outra ocupam o texto usigliano, conforme mostraremos no capítulo 6, dedicado especificamente à rubrica nos autores do corpus.

Vemos dessa forma como gradualmente a mentira elaborada no primeiro ato para levantar recursos financeiros e manipulada no segundo, para não causar infortúnios à família, converte-se em realidade. No último ato, César Rubio aceita totalmente o jogo e, mais do que isso, não consegue deixá-lo, nem sequer exprime frases dúbias.

A mudança em termos de introjeção do jogo da falácia pode ser mais claramente percebida se compararmos duas falas de Rubio denunciando a desfaçatez disseminada em seu país. No segundo ato, tentando convencer Elena de que não agira mal ao mentir para o historiador norte-americano, a crítica é direta, ou seja, não está intermediada por um discurso metalinguístico:

CÉSAR. - Todo el mundo aquí vive de apariencias, de gestos. Yo he dicho que soy el otro César Rubio... ¿a quién perjudica eso? Mira a 
los que llevan águila de general sin haber peleado en una batalla; a los que se dicen amigos del pueblo y lo roban; a los demagogos que agitan a los obreros y los llaman camaradas sin haber trabajado en su vida con sus manos; a los profesores que no saben enseñar, a los estudiantes que no estudian. Mira a Navarro, el precandidato... yo sé que no es más que un bandido, y de eso sí tengo pruebas, y lo tienen por un héroe, un gran hombre nacional. Y ellos sí hacen daño y viven de su mentira. Yo soy mejor que muchos de ellos. ¿Por qué no...?

A elaboração desse discurso se contrapõe ao que dirá na conversa privada com Navarro, pese a que o teor seja praticamente o mesmo. No fim, já imerso no jogo até não mais poder sair dele, expressa-se por comparações com os procedimentos ilusionistas da própria arte teatral: "[En México] Todos usan ideas que no son suyas; todos son como las botellas que se usan en el teatro: con etiqueta de coñac, y rellenas de limonada” (p. 782). A seguir, reproduz uma ideia-chave da dramaturgia de Rodolfo Usigli: "Tú y los tuyos están probados ya y no sirven... están podridos; no sirven para nada más que para fomentar la vergüenza y la hipocresía de México.” (p. 783).

De fato, essa frase possui, ao mesmo tempo, uma moral e uma reflexão metateatral, pois o protagonista emite, no palco, uma opinião sobre a arte e o caráter nacional que remete diretamente àquilo que o autor escrevera em seu ensaio sobre a hipocrisia do mexicano. Tendo em vista essa assimetria poderíamos perguntar se não estaríamos frente a um teatro de tese. A rigor, as denúncias dos desmandos políticos proliferam em toda a obra. Aliás, a ação organiza-se em torno da revelação dos embustes. No entanto, esse último aspecto, a condensação da ação em torno da mentira, possibilita que ela ultrapasse os limites de sua historicidade. Enquanto tema, as consequências negativas da Revolução carregavam ar de novidade à época em que a peça foi ao palco. O mérito maior que torna El gesticulador uma obra singular na história do teatro mexicano consiste em ela ter sido plasmada de modo a se tornar um referencial em termos de composição dramática.

Com efeito, tendo percebido que o historiador César Rubio toma forma cênica de vários aspectos dos ideais estéticos assentados pela dramaturgia de Rodolfo Usigli, cabe ainda destacar dois aspectos muito significativos que estruturam a vida dessa personagem e que dizem respeito ao teatro: o papel do destino no percurso dos homens e da história e a ilusão pessoal de poder conduzir a própria vida.

Como sabemos, o primeiro conceito espraia-se até as raízes mais profundas do teatro ocidental. Na tragédia clássica, o herói vive a queda porque deseja torcer o curso da vida para a qual está predestinado (LESKY, 1938/2003). César Rubio, o historiador, não possui uma vida trágica, no sentido que lhe atribui o termo no teatro, no entanto a 
predestinação está na imagem de um homem que deve dar a vida por seu país e viver predominantemente como mito e não na história. Essa questão, ainda que pareça desvencilhar-se da discussão que travamos até agora sobre as potencialidades metateatrais de El gesticulador, é fundamental, pois Usigli procura uma intertextualidade com as tragédias gregas, mesmo sem reafirmar todas as concepções de mundo incorporadas no gênero clássico. Embora ele fosse um seguidor dos princípios aristotélicos, podemos afirmar que o efeito provocado no espectador difere substancialmente do temor e da culpa buscados pela catarse clássica. O fim trágico de César Rubio convoca antes um desejo de mudança nos rumos da política pós-revolucionária do que o apreço pela permanência dos mesmos princípios.

Esse efeito de revolta estimulado pela peça decorre da presença do conceito de ilusão. Schmeling (1982) afirma em Théâtre dans le théâtre que diversas obras concebidas sob os signos da vanguarda ergueram-se sobre o impulso de romper com a ilusão que a ciência e o progresso projetaram na vida ocidental a partir do século XVIII e praticamente durante todo o século XIX. Nas obras analisadas pelo crítico de origem prussiana, ocorrem ações em ambientes aparentemente alheios aos acontecimentos históricos relevantes.

Conforme se apresentam dentro das correntes teóricas do teatro, destino e ilusão participam do universo coletivo. Em El gesticulador, porém, as ilusões e os sonhos de César Rubio não chegam a causar efeitos catárticos (no sentido aristotélico) porque tudo o que ele deseja é movido por interesses pessoais. Assim, primeiro, no retorno ao povo natal almeja usar seus conhecimentos sobre os partícipes da revolução para instigálos a construir uma universidade para ele lecionar. A seguir, com a chegada de Oliver Bolton, alça voos mais panorâmicos: quem sabe não poderia ser também professor em Harvard? Por fim, a assunção da identidade do líder revolucionário. Elena, perspicaz nesses movimentos interiores do marido, o alerta:

CÉSAR. - [...] No puedo quejarme. Estoy viviendo como había soñado siempre. A veces tengo que verme en el espejo para creerlo.

ELENA. - No es el destino, César, sino tú, tus ambiciones. ¿Para qué quieres el poder?

CÉSAR. - Te sorprendería saberlo. No haré más daño que otro, y quizás haré algún bien. Es mi oportunidad y debo aprovecharla.

O destino intervém na vida de César Rubio ao colocar em seu caminho Oliver Bolton. A denúncia da peça está centrada no fato de que um historiador, que poderia 
construir a verdade sobre os fatos e beneficiar uma nação, torce-os a ponto de servir a interesses particulares. A derrocada dos sonhos e da ilusão pode ser entendida como uma condenação pela mentira. Apesar disso, o imaginário grandioso e extraordinário do líder revolucionário permanece, inclusive porque outra mentira será contada por Navarro, que promete, se eleito, erigir monumentos e instituições com o nome do homem que mandou assassinar.

Os recursos de metateatralidade e o conteúdo de denúncia da peça - que Usigli faz caminharem pari passu — também se configuram já a partir do título. Uma das acepções de "gesticulador" refere-se àquele que realiza mímica, por meio da qual, no teatro, realiza-se a imitação. É pela mímica que o ator explora seu corpo para caracterizar a personagem e mostrar, ao público, uma interpretação. Sobre esse elemento, Maria Helena Pires Martins (1988) destaca que o gesto é marcado pela intencionalidade. Isso o torna um signo, ou seja, um elemento que, no conjunto do universo ficcional criado no palco, produz uma significação e que, portanto, deve ser lido em função do que representa.

No contexto vivido pela sociedade mexicana entre as décadas de 30 e 50 do século $\mathrm{XX}$, em que a busca de um passado era uma das formas mais valorizadas de construção do caráter nacional, Usigli coloca luz sobre a própria função dessa busca, mas não, por exemplo, à maneira brechtiana, em que a perspectiva marxista fundamentava a necessidade de dar um sentido para a história. Existe um desfecho em aberto, algo não resolvido para as personagens, mas teatralmente "mostrado" e historicamente "explicado" 66 no palco para os espectadores, sem com isso romper em sua totalidade a forma ficcional.

Em síntese, percebemos que ao nos deter nas ações miméticas de César Rubio, vemos que a imitação de um ex-general é possível devido a seu conhecimento adquirido como historiador. Em nossa perspectiva, essas são ações marcantes de um metateatro, porque a ilusão de realidade provocada pelo teatro em geral está colocada em cena neste gesto imitativo da personagem. César Rubio é historiador, mas na maior parte da peça não realiza ações próprias de seu ofício. Nelas, ao contrário, predomina a tentativa de imitar o ex-combatente desaparecido e consegue fazê-lo porque conhece bem o papel que

\footnotetext{
${ }^{66}$ Nossa noção de "explicação" em história tem a anuência de Paul Ricoeur em A memória, a história, o esquecimento. (2007). Segundo ele, explicar e compreender são indivisíveis em história. Esse processo é uma das etapas da operação historiográfica. Ele se caracteriza pela tentativa de responder aos questionamentos que os documentos suscitam. Essa tentativa de resolução é que torna possível aproximar a história das demais disciplinas científicas.
} 
quer representar. Assim, nessa fusão inusitada de historiador e ex-general, a veia que mais se destaca é a de ator, intérprete de uma personagem.

Ao identificarmos que a denúncia dos problemas da Revolução e o resgate dos conceitos de destino e ilusão produzem efeitos metateatrais, acreditamos ter desvelado como El gesticulador consegue plasmar no plano artístico as estruturas e os procedimentos que lançaram as bases modernas da dramaturgia mexicana. Doravante, no México, teatro e historiografia experimentarão uma convivência harmoniosa que abrirá caminho para novas obras e gerações.

\subsubsection{Corona de sombra}

Se com El gesticulador a convergência entre ficção e história é colocada no plano temático e formal, em cada uma das obras que integra a trilogia das coroas essa confluência acontece com maior ou menor intensidade. Nelas, diferentemente, não é a abordagem de um evento atual que está em jogo, mas de acontecimentos peculiares e altamente significativos que, para o autor, seriam responsáveis da composição identitária de seu país. Nesse sentido, as três peças da trilogia anti-histórica se aproximam do drama histórico mais tradicional. Por outro lado, haja vista a elaboração anterior de $E l$ gesticulador, cabe, agora, então, vasculhar nos meandros das falas e das ações as implicações estéticas que decorreram tanto da abordagem dos eventos históricos quanto do resgate desse gênero longínguo no teatro ocidental. Algumas questões que norteiam nossa análise estão relacionadas ao papel da reescrita do passado. Perguntamo-nos se ela estaria em função de um diálogo com o porvir ou com o presente. Da mesma forma, queremos investigar se a articulação do enredo fomenta procedimentos cênicos tal como se realizou na peça de 1938. Essas indagações pautam, primeiro, a leitura de Corona de sombra e, a seguir, de Corona de luz. ${ }^{67}$

A primeira obra da trilogia foi escrita em $1943^{68}$ e estreou em 1947 no teatro Arbeu, na Cidade do México. Encenando o debate sobre a soberania política, a ação dramática de Corona de sombra estrutura-se na busca empreendida por Erasmo Ramírez outro historiador fictício, para encontrar a verdade acerca dos acontecimentos que

\footnotetext{
${ }^{67}$ Reforçamos que Corona de fuego será estudada em comparação com outras peças de Leñero e Berman sobre a Conquista do México.

${ }^{68}$ Utilizamos a versão que está no Teatro Completo, vol. II. Doravante, nas citações, indicaremos apenas as páginas, pois todos os trechos serão retirados dessa edição.
} 
desaguaram no fuzilamento do imperador Maximiliano de Habsburgo. Em sua "pesquisa", viaja à Europa a fim de entrevistar a esposa do ex-imperador, Carlota Amalia, quem está acometida pela demência.

Nesta peça o processo histórico se desenvolve diante do espectador, pois os fatos surgem à medida que são rememorados pela imperatriz. Esse recurso torna-se possível pela exploração de três tempos e espaços. Inicialmente, o ano de 1927 situa o presente da enunciação. Erasmo está na Bélgica para entrevistar Carlota, e dos relatos dela emergem os acontecimentos de 1864 a 1867 — a chegada do casal ao México e o fuzilamento de Maximiliano, respectivamente.

Como sabemos, o jogo entre mostrar e aparecer, no teatro, é muito significativo. A apresentação dos fatos tradicionalmente ocorre pela referência das personagens ao que está acontecendo antes do início da ação e a si mesmas. A partir de meados do século XX, obras como Esperando Godot, de Samuel Beckett, lançam mão de uma estratégia que consiste em anunciar um acontecimento e uma personagem que não se fazem presentes nem aparecem nunca. Isso gera uma expectativa do início ao fim da representação. Com efeito, por causa da possibilidade de enunciar, esconder, revelar e criar a expectativa é que se pode dividir o fenômeno teatral em elementos intracênicos e extracênicos.

A análise do elemento histórico a partir dessa divisão demonstra diferenças consideráveis, por exemplo, entre o drama clássico e o histórico. Confrontando os dois gêneros, observamos que enquanto neste a história se situa constantemente em cena, naquele, as personagens evocam os acontecimentos apenas discursivamente, ou seja, como algo extracênico (UBERSFELD,2005).

Em Corona de sombra, o discurso de Carlota é, para o espectador, um elemento intracênico, pois, como dissemos, os acontecimentos são postos em cena à medida que ela os rememora no diálogo com Erasmo Ramírez. No palco, surge um novo espaço e tempo a cada lembrança. Os acontecimentos, os lugares e as personagens emergem não da oralidade discursiva, mas do momento da representação. A história se presentifica em cena à medida que é resgatada pela lembrança da imperatriz,.

Com efeito, podemos dizer que o enunciado histórico cobra vida no momento da enunciação; enunciado que se vincula à memória de uma mulher demente. Apesar de ao longo da trama vermos que pouco a pouco Carlota recobra a consciência, merece destaque o fato de suas reminiscências serem ativadas por e na presença de um historiador. É necessário, portanto, entender o ethos desse profissional dentro do contexto das 
discussões acerca do aproveitamento da histórica para a construção nacional após a Revolução, inclusive porque, como vimos, a escolha do historiador como personagem não é algo esporádico em Usigli.

Nesse sentido, vale lembrar que no século XIX o grupo dos "científicos" de Porfirio Díaz havia proporcionado um conhecimento sobre o México muito questionado pelos intelectuais do momento pós-revolucionário. Criticava-se a imitação de modelos culturais franceses e a perspectiva positivista da historiografia. Porém, a historiografia que tomou corpo depois do movimento armado também passaria a ser questionada a partir da década de 40. As críticas, no geral, denunciam a continuidade de uma visão a priori sobre a Revolução.

Esse processo é esclarecido pelo historiador do Colégio do México Guillermo Zermeño Padilla (1997). Ele defende que na formação da historiografia em seu país teria sido constante a reprodução de um discurso a priori sobre a história, não a partir das pesquisas. Segundo ele, as instituições criadas, sobretudo depois da Revolução, foram responsáveis por fundar esse caráter que determinaria os modos e funções dessa disciplina. Esse discurso a priori teria reproduzido a hegemonia do regime instaurado após os belicosos eventos de 1910 a 1920. Ele chega a afirmar que o Estado delegou às Instituições "el deber de iluminarlo y ennoblecerlo a través del ejercicio y práctica de las humanidades." (ZERMEÑO PADILLA, 1997, p. 443). Em outras palavras, isso significaria que no exercício dos historiadores predominava uma pesquisa mais empírica, sem reflexões teóricas sobre a filosofia da história, que seria subserviente a uma ideologia política e não voltada ao conhecimento do passado. Essa perspectiva, que obedeceria a uma lógica nacionalista do Estado, é sinalizada de maneira muito contundente: "la primacía que ha tenido el empirismo sobre una ciencia reflexiva es un correlato del proceso de construcción de una especie de a priori histórico." (p. 444).

Voltando à peça, vemos que Erasmo Ramírez é um pesquisador empírico; vai a campo colher materiais de seu objeto de pesquisa. Contrariando a perspectiva positivista de que os documentos por si só poderiam contar a história, ele rompe a dimensão do público e privado (PENSORE, 1998). Dessa forma, Usigli consegue relativizar a história no teatro a partir do desvelamento de certos processos de pesquisa historiográfica.

Essa relativização em alguns momentos vem em forma de crítica explícita à maneira como se fazia a história naquele contexto. Na segunda cena do terceiro ato, ao tentar elaborar para Carlota uma cronologia do passado mexicano e universal, Ramírez elenca uma série de informações sobre reis e presidentes mortos entre 1866 e 1927, ano 
em que se passa a cena. A forma mecânica e inarticulada como ele enumera os eventos parece apenas um catálogo com nomes e datas, sem nenhuma intervenção interpretativa nem pretensões de dar sentidos a tudo aquilo. Na continuação do diálogo, Carlota diz o seguinte: "Sois la mirada de México." (p. 215). Após essas palavras, Ramírez se autodefine, dizendo que ele não é "más que un historiador, una planta parásita brotada de otras plantas - de hombres que hacen la historia". (p. 215). ${ }^{69}$

O paradoxal da postura de Ramírez é que, mesmo considerando uma atitude passiva do historiador frente aos fatos, se lança na intimidade de Carlota para encontrar uma explicação dos fatos passados que seu entendimento não alcança. Na sua concepção, a história pode ser reescrita, um novo discurso pode ser construído a partir da memória e do testemunho dos participantes que fizeram a história:

ERASMO - Si he venido a buscaros aquí, señora, fue con la más absurda, con la más descabellada esperanza de encontrar una nueva verdad para la historia de México.

CARLOTA - Pero no la habéis encontrado - ¿no es así?

ERASMO - Hasta ahora no, señora. Estoy en la sombra yo también. No entiendo todavía muchas cosas. La razón misma de que viváis así, por encima de todos los que os amaron, por encima de todos los que os dedicaron su odio, sigue escapándoseme de entre los dedos. (p. 215).

Por outro lado, em outro momento, na última e quarta cena, depois de Erasmo narrar a morte de Maximiliano, Carlota também está prestes a morrer e pergunta ao historiador se ele poderia lhe dizer como seriam os acontecimentos caso alguém pudesse voltar a viver. A resposta de Ramírez deixa claro que a história seguiria exatamente igual, possivelmente porque os fatos não podem ser mudados, apesar de a interpretação sobre eles frequentemente sofrer alterações à medida que avançam os tempos. Assim, já nos momentos finais da última cena, a impossibilidade de modificar a história e de obter resposta sobre seu sentido se confirma:

CARLOTA - Señor. [...] Una última cosa. Si fuera posible volver a vivir la vida, ¿sabéis lo que pasaría?

\footnotetext{
${ }^{69} \mathrm{O}$ questionamento da maneira de viver e produzir história perpassa muitos intelectuais mexicanos. Só para ficar nos exemplos mais renomados, no romance, Carlos Fuentes a concebe como algo circular, em constante retorno. Octavio Paz, como já mencionamos, chega inclusive a expressar que a essência do mexicano está em ser história. O próprio Usigli, com olhar menos artístico e poético à questão, problematizou o processo acadêmico da historiografia. No "Prólogo después de la obra", ele defende que há "numerosas medianías perdidas por su buena intención y su pasadismo incurable." (TC III, p. 624). A explicação desses procedimentos seria porque "la historia, como se hace en México, aun la de la revolución, parece no ser hasta ahora más que una zambullida en el pasado y carecer de todo sentido de actualidad", já que os historiadores mexicanos são "produzidos em massa" (p. 625).
} 
ERASMO - (Con sencillez). Sí, señora. Volveríamos a fusilar a Maximiliano. (p. 221).

A simples enumeração dos eventos e a crença de que há um "determinismo" na história mostram uma característica da historiografia do momento em que a peça foi escrita. Na personagem de Erasmo Ramírez parecem estar condensados os problemas éticos e metodológicos da historiografia daquele contexto. Os debates que levaram à concepção da história como uma construção discursiva e não como testemunho ou manifestação positiva de documentos, estão plasmadas no historiador de Corona de sombra. Traçando uma analogia com a obra estudada no tópico anterior, vemos que diferentemente de César Rubio e Oliver Bolton, Ramírez condensa características de personagens históricos que têm muito a ensinar sobre tempo, história e verdade e dos quais emanam representações discursivas que auxiliam na investigação sobre as formas de se conceber a disciplina historiográfica.

Inicialmente, o prenome remete-nos a Erasmo de Rotterdam, o iminente humanista holandês que viveu a transição do século XV para o XVI e que não foi propriamente um historiador. A aproximação entre ele e a personagem de Usigli é possível porque ambos se vinculam à loucura. Lembremos de sua famosa sátira alegórica Elogio da Loucura, destinada a criticar e denunciar as mentiras, presentes em todas as camadas e grupos sociais da Europa da Renascença. A personagem de Usigli, por sua vez, está confrontada com a demência de Carlota. Na obra do holandês, é a Loucura quem fala; na do mexicano também, ainda que pela voz da imperatriz. A diferença recai no tipo e modo de recepção: em Corona de sombra quem ouve atentamente é um historiador interessado, segundo ele mesmo, na verdade. No Elogio, a Loucura pede que a atenção conferida a ela seja aquela dada aos "charlatães, aos intrujões, aos bobos das palavras" e não a que geralmente se dedica aos "oradores sacros” (ROTTERDAM, 2003, p. 18).

A partir disso, coloca-se a questão do valor a ser atribuído a essa fala. Por um lado, a credibilidade poderia prevalecer, pois, uma vez que a Loucura fala de si mesma, está implícito o pressuposto de que a verdade predomina. Acontece, porém, que os loucos tradicionalmente são excluídos, provocam risos, porquanto

suas palavras são sem sentido e não são de uso humano ou, com maior clareza, não sabem aquilo que estão dizendo; sua fisionomia muda-se a cada instante, e ora estão satisfeitos, ora melancólicos: choram, riem, suspiram, em resumo, estão completamente fora de si. (p. 174). 
Assim, ao aproximarmos a questão da credibilidade por causa da personalidade, é inevitável, dentro do contexto em que estamos discutindo, não pensar que o procedimento de poder dizer a verdade porque se viveu um fato seja algo caro à historiografia clássica. A autoridade conferida pelo testemunho pessoal está também muito vinculada à memória, à capacidade de fazer emergir as lembranças do vivido. Por outro lado, um historiador da modernidade como Erasmo Ramírez pauta-se pelos documentos, pelas fontes. Sua memória é, então, ativada não pelo que viveu, mas pela capacidade de se lembrar dessas fontes e documentos e articulá-los a um discurso lógico, portanto, diferente da expressão dos charlatães e bobos.

Por isso, ao final de seu discurso, a Loucura questiona os ouvintes que possuem boa memória. Expressa que, em vez de oferecer um epílogo sobre toda a "mixórdia de palavras" que inculcou nos ouvintes, prefere oferecer duas sentenças: "eu nunca desejaria beber com um homem que de tudo se recordasse" e "odeio o ouvinte de memória fiel em demasia". (p.175). As sentenças finais rompem com qualquer intencionalidade de manter a atenção dos ouvintes até aquele momento.

Aceita a possibilidade de aproximação entre o Erasmo de Usigli e o de Rotterdam, as sentenças podem, então, ser trazidas para a situação de que nos ocupamos. Como já observamos, o historiador de Corona de sombra sabe demasiadas datas, eventos e nomes de memória. Sabemos, também, que Rodolfo Usigli opunha-se à forma como a historiografia de seu país havia se desenvolvido, principalmente após a instauração do regime de Porfirio Díaz. Poderíamos pensar, então, se questões como estas não subjazem à escolha de vincular a loucura da imperatriz ao historiador: em que contribui esse conhecimento "fiel em demasia" para a construção da história nacional? Não poderiam existir alternativas (não menos verdadeiras) se fosse ouvida a voz da Loucura?

A possibilidade fica mais evidente quando articulamos o sobrenome de Erasmo ao contexto estudado. Ramírez é o sobrenome de um dos mais importantes historiadores mexicanos da primeira metade do século XIX: José Fernando Ramírez (1804-1871). Junto com Joaquín García Icazbaceta (1825 - 1894), Manuel Orozco y Berra (1816 - 1881), Francisco del Paso Troncoso (1842 - 1916) e Juan Hernández y Dávalos (1827 - 1893) “ha sentado las bases de la historia 'rigurosa' y documentada" (SÁENZ CARRETE, 2011, p. 101).

José Fernando Ramírez, natural do norte do México, do estado de Durango (à época Nueva Vizcaya), escreveu diversas obras de história, além de ter contribuído com a redação do código penal de seu estado, mesmo já morando na capital. Esteve vinculado 
a diversas entidades e sociedades dedicadas à pesquisa no México e, na Espanha, foi membro honorário da Real Academia Espanhola. Viveu intensamente o conflito que levou à perda de uma expressiva parte do território do norte do país para os Estados Unidos. Sáenz Carrete (2011) afirma que era profundo conhecedor dos motivos dos dois lados do conflito.

Além de seu trabalho como historiador, outras veias são igualmente importantes, a do político e "bibliófilo". ${ }^{70}$ Sua vertente política é vista como liberal moderada por historiadores como Sáenz Carrete. Interessante notar, porém, que ele participou diretamente do primeiro ano de governo de Maximiliano, em 1864, como Ministro de Negócios Estrangeiros e Marinha. Sua proximidade com o imperador pode ser medida pela citação do trecho de uma das cartas que o monarca enviou à esposa: “hoy cumplió Ramírez 61 años $^{71}$ y lo festejó alegremente con nosotros. Dios le conserve con su espíritu vivo por muchos años.” (KONRAD RATZ apud SÁENZ CARRETE, p. 109). Além disso, aconselhou Maximiliano a que abdicasse do governo quando os liberais triunfaram.

A "bibliofilia" foi cultivada nos dois exílios que sofreu. O primeiro aconteceu em meados de 1855, durante o governo de Antonio López de Santa Anna. Por causa disso, teve oportunidade de percorrer diversas bibliotecas europeias e consultar documentos e livros originais da história de seu país. Passou pela Itália, França e Áustria pesquisando arquivos de bibliotecas com o intuito de elaborar uma história do Império de Maximiliano. No segundo exílio, viveu na Alemanha, na cidade de Bonn, onde faleceu em 1871. Reuniu, nesse momento, milhares de documentos e livros originais da formação de seu país.

O historiador de princípios do século XX Luis González Obregón (apud SÁENZ CARRETE, p. 108) conta que a biblioteca formada por Ramírez em sua estância europeia (conhecida como segunda biblioteca) possuía:

Muchos incunables ${ }^{72}$ del antiguo Continente, gran número de ediciones princeps mexicanas del siglo XVI, crónicas religiosas, folletos rarísimos, infinidades de códices jeroglíficos de los indios, y una espléndida colección de manuscritos, autógrafos ó copiados, relativos

\footnotetext{
${ }^{70}$ Usamos a expressão com muito cuidado porque, embora se mencione que ele era colecionador de livros raros e documentos antigos, em nossas pesquisas não encontramos nenhum pesquisador que a utilizasse para designar José Fernando Ramírez.

${ }^{71}$ Provavelmente a carta é de 1865, ano em que começa o segundo exílio de Ramírez.

72 "Incunables" sãos textos impressos no período que compreende a invenção da imprensa e o século XVI.
} 
á nuestra historia, reunidos, anotados y cotejados á costa de grandes trabajos por el Sr. Ramírez y perdidos para México.

González Obregón usa a palavra "perdidos" porque todos esses documentos foram submetidos a um leilão na cidade de Londres, em 1880.

Além do exílio, outro momento em que Ramírez pode dar curso a sua vertente de bibliófilo aconteceu no processo de laicização de conventos e igrejas após a Independência, quando essas instituições foram saqueadas. Provavelmente essas questões foram facilitadas também porque ele havia sido conservador e diretor da Biblioteca Nacional. (SÁENZ CARRETE, p. 112).

Tema interessantíssimo para a composição de um romance ao estilo de $O$ nome da rosa, o acesso aos livros antigos por parte de Ramírez é, talvez, inconscientemente questionado pelo próprio Sáenz Carrete, embora seu texto não desenvolva a questão - antes prefere exaltar a figura.

Se existe dúvida sobre os ardis de que o historiador exilado na Europa lançou mão para formar sua primeira biblioteca, ela fica excluída da trama de Usigli, no que diz respeito à maneira como Erasmo Ramírez adentra à alcova de Carlota. No entanto, outras comparações autorizam a aproximar os dois historiadores. A primeira delas é a fisionomia. Na caracterização de Erasmo Ramírez, seus traços físicos e vestimentas (ambos indicados pela didascália) acenam para sua origem do norte do México (ele é de Zapotecas) assim como era também o Ramírez histórico. A semelhança faz inclusive que Carlota pense que ele seja Benito Juárez. A segunda aproximação possível é a da importância para a disciplina histórica. José Fernando Ramírez cimenta a historiografia não pela construção de uma metodologia ou teoria. É um pesquisador, digamos, “empírico". Da mesma forma, Erasmo Ramírez age para conseguir saber a verdade sobre o fim do império de Maximiliano e Carlota. A última semelhança está no elemento que caracteriza a personagem. Ele carrega um livro sobre a história do México. Esse código cênico compõe claramente uma personagem que detém um conhecimento livresco, erudito, assim como José Fernando Ramírez tornou-se, em seu segundo exílio, um bibliófilo.

Cremos que essas informações sejam suficientes para mostrar a complexidade da articulação proposta por Rodolfo Usigli ao conjugar em uma única personagem características tão díspares quanto o profundo conhecimento das ações humanas por parte da Loucura (essa cujo domínio se alonga "sobre todas as coisas, e [a quem] mesmo os imperadores mais absolutos estão submetidos" - ROTTERDAM, p. 25) e os 
processos de legitimação da ciência historiográfica em seu país. O mais serão elucubrações. Para seguir adiante, cabe destacar que dentre os estudos de José Fernando Ramírez, estão as crônicas dos primeiros clérigos que chegaram à Nova Espanha. Devese a ele a revitalização, por exemplo, da Historia de los indios de Nueva España, do frei Toribio de Benavente, ou Motolinía. ${ }^{73}$

Esses personagens-cronistas, historiadores no sentido mais amplo da palavra, durante o século XVI serão as próximas personagens a destacar nas duas outras obras que constituem a trilogia das coroas $^{74}$.

\subsubsection{Corona de luz}

A última peça da trilogia é Corona de luz. Composta em 1963, vencedora do Prêmio Latino-americano de obras teatrais em 1965 e montada pela primeira vez em $1968^{75}$. A obra se propõe a problematizar a base espiritual da soberania nacional. Usigli toca em um dos temas mais caros à cultura mexicana, a religiosidade, ao recriar eventos que compõem o imaginário sobre a aparição da Virgem de Guadalupe ao índio Juan Diego. Ao mesmo tempo, é dentre as três obras, aquela que mais explora as inconsistências historiográficas e se pauta pelo diálogo intertextual com documentos e crônicas dos clérigos que participaram da colonização.

A peça está dividida em três atos: "Prólogo político", "Los siete por México" e "La Corona". A ação dramática tem início quando, no primeiro ato, o rei Carlos I da Espanha está passando por Extremadura, em 1529, em direção a Roma para ser consagrado imperador Carlos V do Império Romano Germânico. Junto com sua esposa, Isabel de Portugal, um Cardeal, um Ministro e um Frei, recebe notícias da América por um Emissário. O encontro acontece no mosteiro de São Jerônimo em Yuste por um acaso $^{76}$ : o eixo da carruagem do rei havia se rompido e o único local onde encontraram

\footnotetext{
${ }^{73}$ José Fernando escreveu, em 1859, Noticias de la vida y escritos de fray Toribio de Benavente ó Motolinía uno de los primeros misioneros católicos y fundadores de la Provincia Franciscana del Santo Evangelio de México: acompañadas de investigaciones sobre el origen y motivos de sus disidencias con el Ilmo. D. Fr. Bartolome de las Casas, Obispo.

${ }^{74} \mathrm{Na}$ organização da trilogia, chama atenção que Erasmo de Rotterdam seja mencionado e nas próximas peças apareçam, sobretudo na última, clérigos que chegaram a flertar com o pensamento do holandês. Acerca do erasmismo na Espanha, o livro de Marcel Bataillon (1996), Erasmo y España: estudios sobre la historia espiritual del siglo XVI, é essencial.

${ }^{75}$ Corona de luz estreiou no Teatro Hidalgo, sob a direção de Jorge Gamaliel e cenografia de David Anton e Eugenio Servin.

${ }^{76}$ Mais uma vez, o acaso tem um papel importante nas obras de Usigli. O mesmo já tinha acontecido em El gesticulador.
} 
abrigo foi no mosteiro. As notícias levadas pelo Emissário relatam as dificuldades que os espanhóis estão passando na América para conseguir a adesão dos indígenas à Coroa e, ao mesmo tempo, contam suas ações sobre os nativos. Acerca de Cortés, por exemplo, o Ministro narra que o capitão estaria se sentindo um Adão ao se unir com a "Eva de Tabasco", a Malinche. Os abalos ao poderio espanhol passam também pela representação. Segundo o Frei, os indígenas, em seus "regocijos populares" se disfarçam de Hernán Cortés quando "quieren hacer pensar en un gran jefe o en un dios." (USIGLI, TC II, p. 864). Seja pela possibilidade da transferência simbólica da autoridade a Cortés, seja pelo desejo, menos evidente, de ampliar o império, o fato é que as notícias preocupam o rei e, por isso, ele elabora uma estratégia para acelerar o processo de submissão indígena à Coroa.

A solução encontrada aparece no segundo ato, que ocorre em 1531, nas dependências do bispado da Nova Espanha, às vésperas do dia de Corpus Christi. A ação começa com as inquietações de Juan de Zumárraga, o primeiro bispo do México. Ficamos abendo que ele havia convocado uma reunião com outros clérigos. Assim, entram em cena sequencialmente à medida que a ação avança, os freis Toribio de Benavente (ou Motolinía), o dominicano Bartolomé de las Casas, o também franciscano Martín de Valencia, Pedro de Gante, o agostiniano Vasco de Quiroga e, por último, Bernardino de Sahagún. Todos haviam sido convocados por Zumárraga a fim de lhes anunciar uma decisão que estava prestes a tomar: a de abandonar a missão evangelizadora. Sua decisão era decorrente da ordem dada pelo rei de que se criasse, na Nova Espanha, o milagre do aparecimento da Virgem de Guadalupe de Extremadura, de quem a rainha Isabel era devota. Para auxiliar na tarefa, foram enviados da Europa uma monja sevilhana demente da ordem de Santa Clara, que representaria a Virgem, e um jardineiro, Alonso de Murcia, encarregado de plantar ao sul de Tenochtitlan as rosas que seriam usadas na representação do milagre.

Porém, os religiosos direcionam a discussão para a possibilidade de se realizar ou não o milagre. Dessa forma, no último ato, os clérigos já têm sua opção pela montagem do acontecimento milagroso. Optam pela elaboração de um auto sacramental representando o aparecimento da Virgem. Fica decidido também que o acontecimento seria no dia 31 de dezembro de 1531.

Quando o último ato inicia, surgem novos acasos e coincidências. O primeiro é a presença de Toribio de Motolinía no bispado. O secretário do bispo, Martincillo, diz ao frei que Zumárraga o chama, mas o bispo não sabe se realmente deu a ordem. A seguir, 
Juan de Zumárraga quer anunciar a Toribio de Benavente sua decisão final sobre a realização dos autos.

A partir de então, quatro indígenas, Juan I, II, III (Juan Felipe) e IV (Juan Darío) aparecem para anunciar a visão de estranhos fenômenos. Os dois primeiros têm dificuldades com o espanhol, de maneira que não conseguem explicar o que desejam. $\mathrm{O}$ terceiro relata o aparecimento de rosas no monte Tepeayácatl (ao norte de Tecnochtitlan), o que é confirmado pelo quarto Juan, cuja fluência no espanhol permite contar tudo de forma mais clara. Este último indígena possui em sua tilma rosas. Simultaneamente, ouvem-se as vozes de uma multidão, sempre falando em náhuatl. $\mathrm{O}$ bispo Zumárraga, então, compreende que acontecera o milagre da fé, ou seja, mesmo sem ter visto a Virgem, as pessoas acreditam que algo extraordinário aconteceu, um tlamahizolli, como o frei Motolinía consegue distinguir entre as vozes.

Duas são as tendências de interpretação de Corona de luz. À primeira, alinham-se analistas que tomam a obra como a recriação de um evento histórico cujo propósito é repensar a formação do caráter nacional. Rodríguez (1977) é um dos críticos que se vincula a essa leitura. Em suas palavras, "el propósito del autor es el de rectificar la interpretación historicista y limitada de los mismos, poniendo los acontecimientos históricos al nivel del espectador, para que éste los recree ayudado por la 'poesía dramática”. (p. 37). A opinião não nos parece de todo absurda. Ressaltamos, porém, que sublinha algo bem explícito, ou seja, a representação da história atende muito bem ao projeto de Usigli de pensar o caráter nacional. O que nos parece essencial, por outro lado, é a análise das implicações e dos efeitos de sentido produzidos a partir do instante em que se presentificaria, no palco, a realização de um milagre.

Outra tendência crítica procura verificar aspectos da intervenção religiosa no processo de colonização. Peter Beardsell (1983), por exemplo, utiliza a palavra "fraude" para se referir à criação do milagre. Temos restrições bem acentuadas a essa visão. Em primeiro lugar, devemos observar que Juan de Zumárraga recebe ordens do rei Carlos V para que o "milagre" seja criado, mas em nenhum momento o bispo define por si mesmo se cumprirá ou não a ordem, pelo contrário, convoca outros religiosos, todos conhecedores das "coisas da Nova Espanha", para debater a questão. A ordem é tão espinhosa que, ao longo de toda a ação, os clérigos hesitam em falar de "milagre". Portanto, o conflito colocado, além do próprio aparecimento da Virgem, é o das relações de poder. Zumárraga, quem é visto pela historiografia como um bispo de fortes opiniões, 
hesita entre acatar as ordens do rei ou cometer heresia; negar a ordem equivaleria a desobediência e, portanto, perda do alto cargo.

Essas ponderações acerca da situação de Zumárraga, as quais exploram o nível temático da obra, somam-se a de Denise M. Dipuccio (1986) em "Methateorical histories in Corona de luz". Procurando compreender o processo de construção da peça, ela explora a dramatização do processo de escrita da história. Dessa forma, seria uma peça que "estabelece um fundamento teórico para comparar textos dramáticos, históricos e filosóficos ${ }^{77 \%}$ (p. 29). Acrescentamos que, mais do que o processo de escrita da história, trata-se da escrita ficcional, uma vez que os freis estão encarregados de "criar" uma história e não de contar um fato passado. Outro ponto que nos parece muito forte é que a criação dessa ficção, ou seja, a aparição do milagre, está condicionada a uma ordem política, pois, reafirmamos, Zumárraga encontra-se entre aceitar a ordem real ou mentir, agir contra os preceitos de sua função sacerdotal ou de seu rei.

Com efeito, assim como fizera com El gesticulador, novamente instaura-se na obra de Rodolfo Usigli o tema da falácia na política que passa à historiografia e produz não um conhecimento sobre a história, mas uma ficção que o imaginário incorporaria em um tempo posterior. Além disso, os freis exercem uma função cronística, próxima à de historiadores.

Desse jogo entre mentira e verdade política e entre invenção e registro dos feitos históricos, várias são as camadas em que se desdobra a produção dos fatos em Corona de luz. A primeira é a da participação dos clérigos na conquista, na historiografia e na literatura do México. Outra é a do registro consagrado pela historiografia, tanto sobre a existência ou não do milagre quanto, principalmente, dos estudos acerca do processo de construção do mito. Uma última camada é a da articulação do milagre por meio de um auto sacramental.

Pensando nessas camadas, certamente não passarão despercebidas ao leitor mais afeito à história da colonização algumas inconsistências, apesar de o tema e as personagens serem facilmente reconhecíveis historicamente. Vejamos alguns exemplos. Não há registros que comprovem a ordem dada por Carlos I, nem que, antes de se tornar o quinto soberano do Sacro Império Romano Germânico, ele tivesse passado pelo mosteiro de São Jerônimo em Yuste, na província de Extremadura, com sua esposa Isabel

\footnotetext{
${ }^{77}$ Corona de luz, a dramatization of the process of writing a historical play, not only traces the gradual progression toward a fusion of reality and fiction, but establishes a theoretical groundwork for comparing dramatic, historical, and philosophical texts.
} 
de Portugal. Sabe-se apenas que ele se retirou a esse espaço religioso depois de ter ficado viúvo e já no final de sua vida, entre outros motivos, pela devoção da esposa à santa. Além disso, seria pouco provável a presença de Las Casas no México em 1531, cujos registros o situam apenas entre 1538 e 1546.

No entanto, essas inconsistências foram muito bem pensadas por Usigli, conforme ele mostra no segundo Prólogo (1985). Todos sabemos quanto foi expressiva a participação dos religiosos no processo de colonização. O maior registro dessa importância são justamente as crônicas, as Historias e as Cartas. No contexto da expansão do Império espanhol e mais tarde no da Contrarreforma, sabemos que os frades ocuparam lugar de destaque no processo que cumpria pelo menos dois objetivos, o de expandir a fé cristã católica e instaurar o poder da coroa no Novo Mundo. Inicialmente, os clérigos auxiliariam a consumar a conquista que se realizava pelas armas. Com o tempo, devido à sua cultura, contribuíram para o registro dos fatos, dos costumes, das línguas etc. das diversas sociedades que compunham o novo local conquistado. A esses registros devemos, entre outros temas, o conhecimento das práticas teatrais.

Em todo esse processo, não foram incomuns as divergências entre os clérigos e as ordens religiosas em geral, principalmente em temas que envolviam a conversão dos indígenas. Essas pugnas aparecem representadas na peça de Usigli.

Um caso bastante ilustrativo das incoerências e dos desacordos entre as ordens aparece na carta que Motolinía (frei que tanto contribuiu para a conversão espiritual e para a formação educacional indígena) escreveu ao rei Carlos $\mathrm{V}$, datada de dois de janeiro de 1555, na qual deixa transparecer que às vezes o uso da força era necessário:

pues á V. M. conviene de oficio darse priesa que se predique el Santo Evangelio por todas estas tierras, i los que no quisieren oir de grado el Santo Evangelio de Jesu-Cristo, sea por fuerza; que aquí tiene lugar aquel proberbio, mas vale bueno por fuerza que malo por grado. (MOTOLINÍA, 1980). ${ }^{78}$

$\mathrm{Na}$ mesma carta, inúmeras são as vezes em que Motolinía se opõe abertamente ao frei Bartolomé de las Casas. Veja-se por exemplo logo na sequência do trecho acima, quando o franciscano questiona a validez das palavras do bispo de Chiapas no que tange à cobrança de impostos: ¿Cómo se determina el de las Casas á decir que

\footnotetext{
${ }^{78}$ Pues a Vuestra Majestad conviene darse prisa que se predique el Santo Evangelio por todas estas tierras, y los que no quieran oír de buen grado el Santo Evangelio de Jesús Cristo, [que] sea por fuerza; [por]que aqui se usa aquel proverbio: "más vale bueno por fuerza que malo por grado".
} 
todos los tributos son $i$ han sido mal llevados, $i$ vemos que preguntando al Señor si se daría el tributo á César ó no, respondió que sí, i él dice que son mal llevados? ${ }^{79}$ (MOTOLINÍA, 1999).

O uso da força na conversão e legitimidade para cobrar impostos ficaram expressos nesse trecho, apesar de, no imaginário, permanecer a ideia de que Motolinía era um frei que lutava pelo respeito aos indígenas. Usigli, conhecedor dos documentos, ressignifica a perspectiva sobre o "defensor" apresentando não uma nova versão dos fatos, mas aprofundando o conhecimento proporcionado pelos registros.

Outro destaque é para o franciscano Bernardino de Sahagún. Apesar de na peça de Usigli opor-se fielmente à realização do auto e contradizer as intenções de Motolinía, em sua Historia general de las cosas de Nueva España, o objetivo da conversão e da salvação é acentuado. Assim, ele foi encarregado por seu superior, frei Francisco Toral, de registrar em língua náhuatl "o que lhe parecesse útil” sobre os indígenas para auxiliar na doutrinação da fé cristã. Conforme explica López Austin (2011, p. 355),

Escogió como particulares propósitos de su obra el conocimiento de la religión antigua, para evitar el retorno a la idolatría; el registro de un vocabulario extensísimo de la lengua náhuatl que sirviese para la predicación, y la descripción de las antiguas costumbres para corregir la falsa opinión de que los indígenas poseían un bajo grado cultural antes de la llegada de los españoles.

Por sua empreitada, Sahagún é considerado historiador e antropólogo, pois chegou a aplicar um método próprio de pesquisa, que consistia em colher a informação dos próprios indígenas. "Por haber concebido y aplicado tal procedimiento sistemático, que abarca un enfoque integral histórico-cultural y a la vez filológico (textual) y lingüístico, se ha adjudicado a Bernardino el título de 'padre de la antropología del Nuevo Mundo,"' (LEÓN-PORTILLA, 1999, p. 75). Reescreveu sua obra durante décadas. Com mais de oitenta anos de idade continuou a reescrita dos relatos e dos questionários que preparara para colher informações sobre plantas, animais, religião, política etc. Tudo registrado em língua náhuatl e com comentários e apêndices em espanhol.

\footnotetext{
79 ¿Cómo se atreve el [bispo] De las Casas a decir que todos los tributos son y han sido mal llevados? Sabemos que preguntando al Señor si se daría el tributo a César o no, respondió que sí. Y él [De las Casas] dice que son mal llevados?
} 
Por outro lado, León-Portilla (p. 133) esclarece que a obra “dejó de ser [...] un testimonio debido exclusivamente a la recordación de los vencidos", porque no livro XII, em que se narra a Conquista, revisado e "emendado" em 1585, existem muitas opiniões do próprio autor. Não desejamos entrar nas extensas discussões sobre a reescrita de Sahagún e a possibilidade ou não de ter sido mais ou menos fiel aos relatos ouvidos. Cabe ressaltar, porém, que existem muitos apêndices redigidos somente em espanhol e não em náhuatl. Isso nos possibilita inferir que esses apêndices são paratextos de caráter opinativo.

O apêndice do Livro XI (que trata do mundo natural dos antigos mexicanos) é altamente significativo nesse sentido e tem relação direta com o tema de Corona de luz. No final desse livro, Sahagún alerta para a possibilidade de que os indígenas estejam sendo ardilosos no que diz respeito ao culto da Nossa Senhora de Guadalupe ${ }^{80}$. Ele percebe que o monte de Tepeyac (Tepeácac em suas palavras), onde está a igreja destinada à santa, é o mesmo local de culto à deusa Tonantzin (“nossa mãe” em náhuatl). De acordo com Sahagún, trata-se de um recurso ("una invención satánica") para "paliar la idolatría” à antiga deusa (SAHAGÚN, s/d, p. 329). A evidência que o faz duvidar do culto à santa católica é que muitas pessoas estavam se deslocando de grandes distâncias, isto é, provavelmente ele acreditava que o culto não poderia ter se popularizado tanto a ponto de atingir localidades remotas.

Outro momento em que podemos ver uma preocupação do franciscano não apenas pelo registro, mas também pela colocação de ideias pessoais aparece no apêndice ao Livro IV da Historia general... De acordo com Martínez (s/d), esse apêndice de Sahagún refuta a proposta do frei Toribio de Motolinía no que diz respeito aos calendários náhuatl ${ }^{81}$.

Pela exposição desses dois apêndices de Sahagún, percebemos que ele não se restringe simplesmente ao registro dos eventos. $\mathrm{O}$ fato de escolher em alguns momentos inserir apenas o texto em espanhol é significativo de sua proposta mais engajada. Os excertos representam também as divergências existentes entre os clérigos nas primeiras décadas da conquista.

\footnotetext{
${ }^{80}$ Para conhecimento mais substancial acerca da consolidação do mito da Virgem de Guadalupe no imaginário mexicano, leitura obrigatória é Quetzalcóatl y Guadalupe, de Jacques F. Lafaye (1992).

${ }^{81}$ O nome de Motolinía não aparece explicitamente em Sahagún. O texto diz apenas o seguinte: "Porque algunos se han engañado y aun todavía dura el engaño cerca de ciertas cuentas que estos naturales usaban antiguamente, tengo por cosa provechosa poner aquí la declaración de tres maneras de cuentas que usaban, y aun en algunas partes la usan." (SAHAGÚN, s/d, p. 185). Apesar da falta de menção explícita ao nome de "alguns", sabemos que Motolinía foi um dos cronistas que registrou os calendários.
} 
Além de podermos observar através desses registros as disputas e os conflitos do período, as crônicas guardam a memória das manifestações teatrais, elemento em que também se pauta Usigli em Corona de luz. Acerca desse registro, Aracil Varón (2008), dentre os diversos estudos que abordam o teatro de evangelização, mostra que essa manifestação, tida a priori como expressão religiosa, possuía uma função que extrapolava esse objetivo. Pautando-se pelo cruzamento de informações históricas dadas por cronistas bem como pelas descrições dos autos realizadas por eles, a pesquisadora tenta esclarecer que as representações de cunho religioso muitas vezes "colocavam em cena" tensões políticas do mundo novo-hispano.

Sua hipótese fundamenta-se na possibilidade de que as peças dos franciscanos tivessem alguma herança das chamadas representações de "moros y cristianos", gênero tradicional da Idade Média utilizado com a finalidade de demonstrar o poder cristão nas Cruzadas.

$\mathrm{O}$ auto La conquista de Jerusalén, que segundo a Historia de los indios de Nueva España de Motolinía foi representado em Tlaxcala no dia de Corpus Christi de 1539, deixa isso bem evidente, segundo ela, pois na história um nobre indígena interpreta Hernán Cortés como enviado do exército mouro.

O estudo de Aracil Varón reforça a atitude criativa dos padres a fim de cumprir os propósitos de evangelização e oferece pistas que confirmam a existência de representações teatrais indígenas em que a figura de Cortés assume um poderio superior ao que realmente tinha, conforme anuncia o Emissário ao rei Carlos V na peça de Usigli. Ao mesmo tempo, fica evidente que o propósito das elaborações dramáticas extrapolava os limites da evangelização. Portanto, poderíamos afirmar que a conquista espiritual pode ser vista como uma catarse das articulações políticas.

Para entender melhor o funcionamento e o modus operandi das encenações, é importante lembrar o frei Pedro de Gante, um dos primeiros religiosos a aportar na terra recém conquistada, em 1522. Na chegada ao Novo Mundo, ele se instalou em MéxicoTenochtitlan, mas Cortés lhe solicitou que se mudasse a Texcoco porque havia uma peste assolando a cidade. Ao estabelecer-se, se dedicou a aprender o náhuatl e a ensinar os índios a ler, escrever e cultivar a doutrina cristã. Em 1558, escreveu uma carta ao rei Felipe II, na qual contava as dificuldades pelas quais passava para conseguir evangelizar os nativos. Em seu relato, acentua a diferença entre os indígenas "principais" e "a gente comum". 
Com os primeiros, a doutrinação aconteceu de modo gradual, inclusive porque seus filhos eram deixados nas instituições educacionais e não podiam ter contato com os pais, exceto na hora de receber a comida, levada pelos progenitores. Os jovens mais promissores aprendiam a pregar e a fazer sermões. Alguns delatavam os pais ou outros membros da comunidade caso fosse feita, às escondidas, alguma idolatria. Nesse caso, conta o Fray Gante,

luego los enviaba á llamar á México y venían á llamar á Capítulo, y los reñia y predicaba lo que sentía según Dios me lo inspiraba. Otras veces los atemorizaba con la Justicia, diciéndoles que los había de castigar si otra vez lo hacían; y desta manera unas veces por bien y otras por mal, poco á poco se destruyeron y quitaron muchas idolatrías: á lo menos los señores y principales iban alumbrándose algún poco y conociendo el Señor. (GANTE, In: GARCÍA ICAZBALCETA, 1889, p. 223$)^{82}$.

Porém, "la gente común estaba como animales sin razón, indomables", "huían como salvajes de los frailes", por isso, tardou mais de três anos para conseguir apresentar a eles a doutrina. (GANTE, In: ICAZBALCETA, 1889, p. 223).

Com o tempo, começou a entendê-los e perceber como deveria se aproximar deles:

y es que toda su adoración dellos á sus dioses era cantar y bailar delante dellos, porque cuando habian se sacrificar algunos por alguna cosa, así como por alcanzar vitoria de sus enemigos, ó por temporales necesidades, antes que los matasen habían de cantar delante del ídolo; y como yo vi esto y que todos sus cantares eran dedicados á sus dioses, compuse metros muy solemnes sobre la Ley de Dios y de la fe, y cómo Dios se hizo hombre por salvar al linaje humano, y cómo nació la Virgen María, quedando ella pura é sin mácula; y esto dos meses poco más ó menos antes de la Natividad de Cristo, y también díles libreas para pintar en sus mantas para bailar con ellas, porque ansí se usaba entre ellos, conforme á los bailes y á los cantares que ellos cantaban así se vestían de alegría ó de luto ó de vitoria; y luego, cuando se acercaba la Pascua, hice llamar á todos los convidados de toda la tierra, de veinte leguas alrededor de México para que viniesen á la fiesta de la Natividad de Cristo nuestro Redemptor, y ansí vinieron tantos que no cabían en el patio, que es en gran cantidad, y cada provincia tenía hecha su tienda adonde se recogían los principales, y unos venían de siete y ocho leguas, en hamacas enfermos, y otros de seis y diez por agua, los cuales oían cantar la mesma noche de la Natividad de los ángeles 'hoy nació el Redentor del mundo. (GANTE, In: GARCÍA ICAZBALCETA, 1889, p. 223-224).

\footnotetext{
82 A Universidade Autônoma de Nuevo León disponibiliza uma versão totalmente digitalizada dos Documentos para la historia de México, de Joaquín García Icazbalceta. Por isso, indicamos, na referência, a data de 1889.
} 
A importância e a beleza do relato justificam a extensão da citação: Pedro de Gante promove a evangelização dos indígenas, colabora com a didática dos religiosos, registra o costume daquela sociedade e, por fim, projeta um conhecimento que será buscado por Rodolfo Usigli muitos séculos depois.

O uso do teatro como forma de evangelização a partir do entusiasmo dos indígenas para a festa foi mostrado também pelo frei Toribio de Benavente. Em sua Historia de los indios de Nueva España, Motolinía (em náhuatl "pobre" ou "aflito"), apresenta mais informações sobre a função missionária dos franciscanos do que propriamente a história dos nativos. Muito do que se sabe dos autos representados no período entre 1536 e 1539 é oriundo desse livro.

O capítulo XV do Tratado I ("De las fiestas de Corpus Christi y San Juan que celebraran en Tlaxcallán en el año de 1538”) merece leitura mais acurada. A descrição dos adereços e dos usos de enfeites de toda ordem não deixa dúvida do esmero com que os indígenas trabalhavam nos dias de festas. O próprio Motolinía fica maravilhado: "había bien en que poner los ojos y notar, como una gente, que hasta ahora era tenida por bestial supiesen hacer tal cosa." (MOTOLINÍA, 2012, p. 79).

Após a descrição das grandiosidades, em um relato capaz de produzir grande verossimilhança por causa das imagens dos enfeites e dos acompanhamentos ornados com ouro e plumas, flores de diversas índoles e, sobretudo, rosas, Motolinía passa a descrever a representação dos quatro autos representados no dia da celebração de São João Batista.

Porque se vea la habilidad de estas gentes diré aquí lo que hicieron y representaron luego adelante [después del día de Corpus Christi] en el día de San Juan Bautista, que fue el lunes siguiente, y fueron cuatro autos, que solo para sacarlos en prosa, que no es menos devota la historia que en metro, fue bien menester todo el viernes, y en solo dos días que quedaban, que fueron sábado y domingo, lo deprendieron, y representaron harto devotamente la anunciación de la Natividad de San Juan Bautista hecha a su padre Zacarías, que se tardó en ella obra de una hora, acabando con un gentil motete en canto de órgano. (MOTOLINÍA, 2012, p. 81).

Depois disso, em outro "palco" teria sido representada La Anunciación de Nuestra Señora com tempo da representação similar à anterior. A seguir, vinha a procissão até o pátio da igreja de São João, onde se representava mais um auto, o da Visitación de Nuestra Señora a Santa Isabel. Motolinía demonstra-se surpreso (e poderíamos dizer "encantado") por ver a preparação dos indígenas para as festas. Em determinado momento, seguramente para não parecer uma visão subjetiva, insere um 
trecho de uma carta de um frade morador de Tlaxcala, Don Antonio Pimentel, em que é reforçada a capacidade e o empenho com que os indígenas se preparavam para os dias festivos.

No entanto, "lo más principal" da carta de Don Antonio ele deixa "para la postre, que fue la fiesta que los confrades de Nuestra Señora de la Encarnación celebraron". Trata-se de um auto "que fue la caída de nuestros primeros padres, y al parecer de todos los que lo vieron fue de las cosas más notables que se han hecho en esta Nueva España." (p. 84). Depois, o frade faz uma descrição minuciosa do cenário e um resumo das cenas e conclui: "Esto fue tan bien representado, que nadie lo vio que no llorase тиу recio". (p. 85).

Em Corona de luz, é justamente o próprio Motolinía quem dá a ideia de realizar o auto e depois presencia a entrega das rosas por Juan Darío. No segundo ato, quando há a discussão dos sete clérigos, ele é um dos primeiros a ponderar que a ideia do rei não era de todo absurda:

Perdonadme. No he podido menos que relacionar... Digo que, como lo sabéis, he pensado siempre en la necesidad de organizar representaciones sacras para apresurar la evangelización de nuestros hermanos indios: la tentación y caída de Adán y Eva, la Conquista de Rodas y la de Jerusalén para enseñar al indio cómo se abre paso la Cruz de Cristo en tierras infieles, las propias predicaciones de nuestro jefe San Francisco a las aves... Nos ayudaría tanto eso a cumplir con nuestra misión y tarea santa... (TC II, p. 880).

Durante a conversa, as falas de Motolinía demonstram conhecimento dos elementos e recursos teatrais. Em determinado ponto da discussão, Pedro de Gante propõe que seja feito um exercício de imaginação. Sugere que os sete pensem como seria realizado o auto, caso fosse aceito por Zumárraga. É Motolinía quem sintetiza as ideias que vão surgindo:

Entonces, supongamos, hermanos, que tenemos ya el lugar de la acción, el escenario, los personajes y el diálogo. Se aparecerá una virgen a un indio inocente y le dará un mensaje para salvación de su alma y del alma de todos los naturales, ¿no es así? ¿Qué hará el indio entonces? (TC II, p. 887).

Trouxemos ao centro da discussão esses dois cronistas, Pedro de Gante e Motolinía, responsáveis pelo registro das manifestações culturais que aportaram condições para a existência de um teatro na Nova Espanha, a fim de mostrar como a presença dessas personagens obedece a um princípio de construção marcado pela 
intertextualidade com a história e com as expressões teatrais dos contextos em que elas viveram.

A observação dos processos de intertextualidade utilizados nessa obra levanta a questão dos modos de se apropriar de textos de forte enraizamento nas tradições. A busca pelas marcas mais remotas das expressões teatrais não revela a apropriação dos recursos descritos em muitas crônicas. Criada em um contexto de plena modernização do México, Corona de luz não nega a existência do milagre, mas, no nível da forma dramática, tampouco vai às primeiras células da expressão popular. Desse modo, verificamos que nela se produz a conjunção de elementos tradicionais e modernos. A tradição estaria na reafirmação do milagre e de todo o significado que ele carrega dentro da cultura mexicana e a modernidade seria conquistada por uma arquitetura dramática que não se apropriava de elementos cenicamente tradicionais. ${ }^{83}$

No início do capítulo, mencionamos que Corona de luz seria uma das obras anti-históricas em que haveria o maior número de inconsistências históricas. Vemos como a articulação das pugnas que aconteceram entre os religiosos protagonistas da peça e da história a filia a uma longa tradição dramática que se apropria de documentos e registros históricos para reelaborá-los. No México de meados dos anos 60, essa apropriação significou a vinculação a um teatro de caráter universal, por causa do uso de recursos que o afastavam das expressões mais populares, tais como o teatro de carpa e o de revista.

No que tange ao tema abordado, por outro lado, o enraizamento popular se sedimenta pela manutenção do mistério do aparecimento da Virgem. Trabalhando com o imaginário, ele não é desmentido, pois, no universo intracênico, os espectadores enxergam apenas a luz que emana da tilma de Juan IV e das vozes da multidão enunciando um milagre. $\mathrm{O}$ mito persiste, embora a trama sugira que entre o registro e o fato histórico aconteçam articulações inusitadas.

\footnotetext{
${ }^{83}$ É pertinente notar que Usigli, apesar de resgatar significativas informações da época acerca das primeiras manifestações teatrais do México no século XVI, não demonstra grandes empenhos nem apreço pelas apresentações. Sua análise, aliás, parece às vezes desdenhosa, no sentido de não encontrar ali nada que the impulsionasse a recuperar aquela tradição: En estos especímenes - todos en mexicano [...] - tenemos ya representada, prácticamente, toda la diversidad de formas del teatro de la Edad Media: episodios del Antiguo y del Nuevo Testamento, milagros - vidas o acciones de santos - misterios, moralidades, etcétera, aun cuando la representación sea un tanto irregular y arbitraria. (USIGLI, TC IV, p. 48).
} 


\subsection{Anti-história e hipocrisia: enfim um teatro para o México?}

Tentamos mostrar, com a leitura de El gesticulador e de duas Coronas, de que maneira a imaginação e a verdade dramática (a verossimilhança interna) predominam sobre a história na obra de Rodolfo Usigli. A articulação intertextual com os documentos históricos acontece com o intuito de motivar a construção do argumento e da nação sem, porém, seguir à concepção estatal de nacionalismo. No entanto, se o pano de fundo que se descortina aos olhos do espectador é a Revolução, a perda do império de Maximiliano ou a aparição da Virgem de Guadalupe, é pensando na utilização dos elementos constitutivos do teatro para transcender a problematização histórica.

O próprio dramaturgo declarava, sem nenhuma modéstia, que marcaria definitivamente a história do teatro mexicano: "soy hasta ahora, por tuerto privilegio, ${ }^{84}$ el único ojo penetrante del teatro mexicano y el primer dramaturgo serio y apasionado del país” (USIGLI, 1985, p. 50). Ainda que essa opinião deva ser ponderada porque os grupos e dramaturgos contemporâneos a ele, ou seja, os integrantes de um teatro de vanguarda, também fizeram contribuições significativas, não se pode negar que peças como El gesticulador assentaram as bases do teatro usigliano e mexicano. Pelo mergulho nos temas e problemas típicos de seu país conjugados aos princípios da teatralidade, ele conseguiu consolidar uma forma dramática das mais representativas. Partindo do pressuposto de que o jogo de mostrar e revelar é marca típica do teatro, Usigli tornou fulcral o conceito de hipocrisia para pensar as verdades e mentiras do universo político. A consequência foi que a história, mais do que um elemento cultural a representar, assentou as bases para repensar a própria ficcionalidade.

Assim, a temática em El gesticulador abriu recursos para o aprofundamento para questões oriundas da historiografia. A ficcionalidade das personagens e dos eventos do passado ofereceu, então, a oportunidade de pensar a política e a própria dramaturgia do presente. Com efeito, as três coroas tratam, em conjunto, de evidenciar esse processo: história, mentira e ficção sintetizam a sequência da trilogia. A história que está nas sombras projetadas por uma forma mecânica de reproduzir conhecimentos é queimada (e forjada) no fogo das articulações políticas e na força dos governantes para ser reelaborada pelas luzes da arte.

\footnotetext{
${ }^{84} \mathrm{O}$ “torto privilégio" é obviamente uma brincadeira do autor com seu estrabismo.
} 
Não é gratuito, portanto, que na trilogia Rodolfo Usigli tenha recorrido mais a personagens que escreveram a história e menos àquelas que a fizeram. Dessa forma se processa a metateatralidade das obras anti-históricas. Os actantes responsáveis pelos registros têm consciência de sua posição no tempo e na cultura. Um historiador "empírico" motiva Carlota Amalia a recobrar a consciência; os frades-cronistas sabem que o teatro também requer um ato de fé; por fim — como veremos no capítulo 7 - Bernal Díaz del Castillo sabe que escreverá a crônica algum dia e Cuauhtémoc: todos esses "historiadores" são convictos de estarem construindo uma nação. 


\section{Capítulo 4 - Vicente Leñero: a história pensada}

A produção literária de Vicente Leñero pauta-se pela multiplicidade de expressões. Graduado em engenharia civil, tornou-se romancista "por acaso" e contista e dramaturgo "por opção ou devoção", conforme expressou em inúmeras entrevistas. Nascido em 1933, em Guadalajara (Jalisco), faleceu em 2014 na Cidade do México, onde atuou como jornalista durante quase toda sua vida. Neste momento, estamos diante de um autor profícuo cuja obra dramática, tão abundante quanto a prosa, está reunida em dois extensos volumes pela editora Fondo de Cultura Económica.

Ainda como estudante de engenharia na UNAM, solicitou ao Centro Mexicano de Escritores uma bolsa para escrever contos. Sua primeira solicitação foi negada e, na segunda vez, lhe deram por equívoco uma para escrever romances. Dessa experiência nasceu Los albañiles, obra na qual se vê, desde o título, seu vínculo com o universo da profissão que estudava. Com esse romance, Leñero conquistou o primeiro lugar no concurso da Biblioteca Breve da editora Seix Barral, em 1963.

$\mathrm{Na}$ história da dramaturgia mexicana, ele representa um ponto de inflexão importante, porque, formado com os autores do período posterior a Usigli, projeta para um número expressivo e competente de criadores as bases da Nova Dramaturgia. Ousaríamos dizer, inclusive, que ainda falta um estudo que mostre seu vínculo com a Novíssima Dramaturgia e os representantes da Dramaturgia do Norte. Essas relações acontecem primeiro porque Leñero teve uma vida longeva e atuante até os momentos finais de sua vida. Somado a isso, ministrou muitas oficinas de escrita, nas quais pôde expor seus princípios.

Seus temas giram em torno dos problemas sociais e políticos mais imediatos da história, nos quais busca uma perspectiva universal a partir de protagonistas que estão sempre em conflito com a coletividade. Assim, emergem motivos como a busca pela verdade, a culpa, a aceitação dos dogmas e das instituições. De fato, observamos que o passado imediato ocupa espaço predominante nas primeiras obras, as da década de 1970. Com o amadurecimento, os eventos mais remotos cobram proeminência.

Embora nesse aspecto sua trajetória se assemelhe à de Usigli, identificamos que o objetivo já não é o de construir ou imaginar a nação. $\mathrm{O}$ manejo de procedimentos ficcionais que se detêm nos problemas sociais, políticos e culturais imediatos provém da carreira jornalística, que exerceu, por exemplo, na revista Claudia e no jornal Excélsior. 
Esse procedimento é peculiar na produção teatral mexicana daquele momento porque produz, simultaneamente, uma continuidade e uma ruptura. Dá seguimento a uma tradição na medida em que aborda um tema histórico e utiliza documentos para a construção dos diálogos, como fizera também Usigli, mas rompe com a estrutura aristotélica ensinada, cultivada e continuada - com pequenas mudanças - pelos discípulos dele. Essa mudança surge porque as primeiras obras de Leñero se aproximam de uma teatralidade de matriz épica. Veem-se aí as contribuições de Erwin Piscator, Peter Weiss e Bertolt Brecht, tais como a construção de quadros e a escrita a partir de textos jornalísticos. ${ }^{85}$

A ênfase de suas obras nos conflitos do tempo presente está em sintonia com os turbulentos anos que lhe coube vivenciar. Após o esplendor econômico e desenvolvimentista ${ }^{86}$ das décadas de 40 e 50 , a de 60 terminava com uma perspectiva pessimista, tanto na política quanto na economia. No contexto das demonstrações de força exercidas pelo governo no emblemático 2 de outubro de 1968 na praça de Tlatelolco, aparece em novembro a montagem da primeira peça: Pueblo rechazado. Desse período até a eleição de Miguel de la Madrid Hurtado para Presidente, em 1982, as dúvidas sobre o esfacelamento das instituições e das formas de condução do governo tornaram-se motores da aproximação da escrita ficcional aos gêneros mais pautados pela representação da realidade imanente.

Com efeito, o teatro de Leñero torna-se "histórico" na medida em que usa o documento como elemento estruturante. "Pas de documents, pas d'histoire", ensina a lição de Charles-Vitor Langlois e Charles Seignobos. No caso de Leñero, cria-se uma linha até aquele momento timidamente contemplada - pensemos no Usigli da trilogia das Coroas -, a de explorar os documentos jornalísticos para dar forma a uma ação dramática.

Para explorar a dramaturgia desse "precursor" de novas gerações (PARTIDA TAYZAN, 2002b), escolhemos três peças. A princípio, serão analisadas Pueblo rechazado e Martirio de Morelos. Com elas, pretendemos sistematizar a passagem da dramaturgia documental a partir de eventos históricos imediatos para aquela que articula

\footnotetext{
${ }^{85}$ Sublinhamos que os recursos épicos e documentais não foram exclusividade dele. Abordaremos a questão mais cuidadosamente nas próximas páginas. Por ora, lembramos que, no mesmo contexto, autores como Maruxa Vilalta (1932-2014) e Óscar Villegas (1937-2003) também construíam enredos organizados por quadros tratando de temas atuais. A peculiaridade de Leñero recai no impacto que causou nas gerações posteriores, além de, dentro do escopo desta pesquisa, ter incorporado os temas históricos.

${ }^{86}$ Hector Aguilar Camín e Lorenzo Meyer (2009) elencam os seguintes aspectos desse período, que os autores chamam de "milagre mexicano": urbanização, substituição de importações, crescimento econômico de $6 \%$ a.a., estabilidade do câmbio, equilíbrio de preços e salários.
} 
os recursos documentais ao passado mais remoto. A terceira obra, La noche de Hernán Cortés, é analisada em conjunto com as peças de Usigli e Berman sobre a Conquista.

Antes, porém, exploramos o universo da cultura e do pensamento mexicanos a fim de solidificar o panorama histórico-cultural dos anos em que emerge a dramaturgia de Vicente Leñero.

\subsection{O mexicano: um ser-ante-a-história}

A partir de meados do século XX, assistimos a uma guinada nas concepções sobre a história e o ser mexicanos. Grosso modo duas tendências de pensamento se destacam no panorama crítico. Uma delas foi a transição de uma análise da identidade fundamentada na história e nos costumes para outra de caráter introspectivo. Se no conturbado período revolucionário a psicologia e a sociologia deram os fundamentos da discussão acerca da identidade nacional, a partir dos anos 50 os pilares são construídos pela filosofia. Outra tendência se caracterizou pela postura mais combativa na arte. As décadas de 1960 e 1970, sobretudo após os movimentos estudantis de 1968 e 1971, a atuação censora do governo e a eleição de Luís Echeverría, exigiram dos intelectuais novas ferramentas analíticas. Muitos se lançam, então, a compreender o presente político e social e interver nele por meio de expressões artísticas de cunho engajado.

A transição do fundamento psicológico para o ontológico é motivada pela ação intelectual do grupo Hiperión. Formado por professores e alunos da Faculdade de Filosofia e Letras da UNAM, o grupo atuou entre 1948 e 1952, apesar de individualmente os membros terem construído carreiras ao longo das décadas seguintes. A primeira atividade foi um ciclo de conferências sobre o existencialismo francês, realizado na primavera de 1948. Outros encontros aconteceram nos anos seguintes, com temas relevantes para a filosofia e o pensamento. “QQué es el mexicano?” (1949), “El mexicano y su cultura" (1951) e "El mexicano y sus posibilidades" (1952) são textos cujos títulos explicitam sobremaneira o escopo da ação reflexiva.

Àquela época, a Cidade do México era um território imerso em atividades culturais. Desde o Ateneo de la Juventud, a Sociedad de Conferencias y conciertos, Los contemporáneos, nas décadas anteriores, muitos grupos haviam surgido. A peculiaridade de Hiperión reside em sua dedicação à filosofia. Nesse sentido, mais do que uma reunião de intelectuais com pretensões artísticas, conformaram-se como intelectuais acadêmicos. 
Os hiperiones, como foram chamados os integrantes, tinham um discurso motivado pelas transformações profundas na cultura e no ser mexicanos vistas inicialmente pelo pensamento existencialista de Jean-Paul Sartre. Assim, as motivações nacionalistas da geração anterior se vinculavam às reflexões sobre a identidade e a história nacionais e a questões universais.

Em suma, as pesquisas e reflexões dos hiperiones procuraram conciliar a filosofia existencialista e as questões acerca da mexicanidade e do nacionalismo que estiveram na ordem do dia desde os primeiros anos após a Revolução. Essas duas vertentes eram unidas na busca de um sentido para o ser humano. Não se tratava de um sentido abstrato, mas de uma humanidade concreta, situada historicamente. Em outras palavras, queriam pensar o ser humano a partir do mexicano. Guillhermo Hurtado (p. 5) afirma que

la manera en la que se pretendía capturar el núcleo activo del ser del mexicano era a través de la descripción sistemática de las formas de vida, los rasgos de carácter, los gestos, las obras artísticas, literarias $y$, en especial, la historia de los mexicanos (el mexicano, decían, no tiene historia sino que es su historia).

Como se observa, havia um método fenomenológico e imanente. A propósito, falar em método de estudo confirma a perspectiva acadêmica adotada pelo grupo. Isso é o que o diferencia dos demais autores que haviam pensado as características do mexicano nas décadas anteriores, já que a forma ensaística - e de certo caráter didático — havia sido a marca do pensamento de José Vasconcelos, Antonio Caso, Alfonso Reyes, Rodolfo Usigli e Samuel Ramos.

Entre os hiperiones, Antonio Caso havia se preocupado com o "bovarismo" do México; Gabriel Tarde estudara a "imitação extralógica" e Agustín Yáñez, autor também do romance Al filo del agua, cuidara do ressentimento. Todas essas análises têm cunho mais psicológico do que filosófico. Jorge Portilla, por sua vez, realizou a obra Fenomenología del relajo. O “relajo", segundo ele entendia, é uma suspensão temporal dos valores em um contexto social específico. Reyes Nevares escreveu sobre El amor y la amistad en el mexicano, obra em que destaca o tom emocional e afetivo de sua nação. Porém, a obra de maior envergadura é atribuída a Emilio Uranga. Crítico da tese principal de Samuel Ramos sobre o complexo de inferioridade, ele publicou Análisis del ser del mexicano, em que busca uma verdadeira exploração ontológica e metafísica. 
Ao mesmo tempo, a filosofia dos hiperiones estava orientada, desde seu projeto, a uma ação liberadora do ser humano. Exemplo dessa postura é o ensaio "La filosofía como compromiso", de Leopoldo Zea, publicado em 1949, ou seja, nos primeiros anos de Hiperión. Devido à base sartreana desse ensaio, Zea tinha consciência de que os problemas colocados para o filósofo francês não eram os mesmos que se apresentavam para os mexicanos. Daí a necessidade de se debruçar sobre suas peculiaridades para dar respostas concretas a elas.

Outra forte característica que diferencia os hiperiores dos primeiros pensadores da cultura e da nacionalidade é a apresentação de aspectos positivos. Antonio Caso e Samuel Ramos, por exemplo, tinham enfatizado características negativas, tal qual a imitação de povos europeus. Por outro lado,

Uranga sostiene que los aspectos negativos del mexicano descritos hasta entonces, como el resentimiento, la hipocresía, la melancolía, la sentimentalidad, el complejo de inferioridad, etc., no son sino expresiones superficiales de lo que él llama accidentalidad, que es una modalidad existencial constitutiva del mexicano y manadero de sus posibilidades más auténticas. (HURTADO, p. 10).

Apesar dessas diferenças, salta à vista o modo como a história ${ }^{87}$ ocupa também um lugar de relevo no pensamento de ambas as gerações. A Revolução, por exemplo, é colocada no centro do debate. Os pensadores e artistas que vivenciaram o conflito acreditaram nele, mas se decepcionaram com seus resultados. Por outro lado, em consonância com a estabilidade política dos anos 40, os integrantes do grupo Hiperión valorizaram daquele período o despertar para a mexicanidade. Leopoldo Zea, inclusive, procura fazer uma filosofia da Revolução.

Em definitivo, se percebe que com o grupo Hiperión o homem passa a ser categoria de pensamento. Dois livros publicados em 1950 representam bem a mudança. O de Luis Villoro, Los grandes momentos del indigenismo en México, e de Octavio Paz, El laberinto de la soledad ${ }^{88}$, que, mesmo sem integrar formalmente o grupo, compartilha as preocupações e se aproxima dele em algumas conclusões. Em ambos os ensaios de

\footnotetext{
${ }^{87}$ Para se ter uma dimensão da importância da história para a filosofia, sublinhamos que, em um dos principais estudos sobre o indígena até aquele momento (Los grandes momentos del indigenismo em México), Luis Villoro (1950/1998), um dos mais atuantes membros do grupo, ao defender as contribuições de seu ensaio, destaca que lançará ideias para a filosofia da cultura e da história, enfatizando que a primeira está fundada sobre a segunda.

${ }^{88}$ Apesar de a primeira edição ter sido em 1950, a segunda, de 1959, trouxe mudanças expressivas nos conteúdos e na organização do livro.
} 
análise do mexicano, emerge o humano, ou, em outras palavras, a abstração filosófica do ser é realizada a partir da imersão em "lo" mexicano.

Diferentemente do que realizamos com o ensaio de Samuel Ramos, não vamos nos deter nesses dois livros, porque as questões levantadas por Villoro (e pelos hiperiones de maneira geral) objetivam a construção de uma filosofia, algo que escapa dos nossos interesses.

De Octavio Paz, interessa-nos apenas um detalhe que acreditamos ser pertinente em decorrência de seu ineditismo naquela tradição. Como observamos no primeiro capítulo, os processos de modernização, conforme teorizou Gellner (1993), englobam aspectos como escolarização e industrialização. A educação havia sido o elemento fulcral da ação de José Vasconcelos e do pensamento de Samuel Ramos. Por outro lado, o desenvolvimento sob os moldes da modernização é um tanto quanto tímido nesses autores. Já em Octavio Paz ela ganha destaque. O tema é tão caro ao poeta que, vinte anos depois, quando ele revê El laberinto em Postdata, verificamos sementes daquilo que chamamos hoje de globalização e neoliberalismo, ou seja, preocupações que estão marcadamente voltadas para problemas econômicos e seus impactos na cultura.

O último ensaio de El laberinto de la soledad, "Nuestros días", é representativo do deslocamento sofrido pelo pensamento nacionalista. Paz acentua o processo de modernização após o movimento revolucionário. Uma marca importante, um tanto quanto ambígua, é que a Revolução teria gerado o capitalismo que se praticava então, aproximando-o de um modelo mais globalizado. Embora se possa hoje criticar o fato de que em sua análise Paz toma sempre como referente dos processos de desenvolvimento os EUA e a Europa, devemos reconhecer que a boa interpretação dos mecanismos de imperialismo, cujo método mais característico é a subserviência pela venda, a baixo custo, de matérias-primas e compra de manufaturados a custos elevadíssimos.

Outra característica decisiva da modernização mexicana naquele momento se revelava na contradição entre leis nacionalistas e a abertura para o mercado norteamericano. Paz (1993, p. 196) expressa o conflito nos seguintes termos: "a pesar de la legislación nacionalista, el capital norteamericano es cada día más poderoso y determinante en los centros vitales de nuestra economía.

A análise segue com a crítica aos sistemas capitalista e o socialista. Do primeiro, o poeta duvida de sua suposta "lógica histórica" que permitiria o desenvolvimento a todos, sem exceção, desde que seguidos os mesmos passos. Do segundo, denuncia a mentira da possibilidade de igualdade e as opressões a que são 
submetidos os indivíduos. "Ni con la mejor buena voluntad se puede afirmar que el proletariado ha sido el agente decisivo en los cambios históricos de este siglo.” (p. 201), afirma em determinado momento, sintetizando a crítica a um e a outro modelo.

O último ensaio de El laberinto de la soledad parece ter o objetivo de colocar em evidência a tese de que historicamente ocorriam mudanças na participação das nações periféricas, algo que se pode ver no trecho a seguir:

En casi todas partes - trátese de Indonesia, Venezuela, Egipto, Cuba o Ghana - los ingredientes son los mismos: nacionalismo, reforma agraria, conquistas obreras y, en la cúspide, un Estado decidido a llevar a cabo la industrialización y saltar de la época feudal a la moderna. (p. 201) ${ }^{89}$.

Como se percebe, o nacionalismo é o impulso do processo de inserção na história ocidental. Porém, o processo descrito no trecho acima difere dos tradicionais pelos quais passaram os países "avançados" (Paz sempre usa aspas nessa palavra). A aproximação seria pelo processo de participação na história universal: “anexados al destino de Occidente por el imperialismo, ahora se vuelven sobre sí mismos, descubren su identidad y se deciden a participar en la historia mundial.” (p. 203).

Analisando esse pensamento do poeta, David Brading (1991) afirma que ele estaria assumindo uma perspectiva profética da história do México. ${ }^{90}$ Visão que ele denomina como sendo a de um "liberal desencantado que volvía al primer romanticismo para articular una visión de México, de su gente y de su historia." (BRADING, 1991, p. 39). Porém, não se pode negar que a exposição de Paz em "Nuestros días" insere as preocupações com a economia como cerne dos debates. Essa perspectiva que substituiria, nos umbrais da pós-modernidade, as metodologias e paradigmas de estudo do Estado e da nação, tal qual Hobsbawm (2004) afirma que teria acontecido em certo momento no mundo europeu.

Todas essas reflexões que Octavio Paz realizou em Postdata de certa forma estão em consonância com a postura mais engajada. O olhar sobre o contexto histórico mexicano nas últimas décadas do século $\mathrm{XX}$ consente a assertiva de que se faziam

\footnotetext{
${ }^{89} \mathrm{O}$ trecho tem algo também muito relevante: a análise não está restrita ao universo mexicano. Pelo percurso que traçamos desde o início deste capítulo, fica evidente uma expansão das dimensões nacionais. ${ }^{90}$ Não seria exagero pensar que essa visão profética já estaria na "missão" da raça imaginada por Vasconcelos. O autor de La raza cósmica também acreditava que seu país havia assumido as rédeas da própria história após a Revolução. Veja-se a pergunta retórica do autor que nos leva a acreditar na visão profética: “Qué importa que el materialismo spenceriano nos tuviese condenados, si hoy resulta que podemos juzgarnos como una especie de reserva de la humanidad, como una promesa de un futuro que sobrepujara a todo tiempo anterior?" (VASCONCELOS, 1997, p. 77).
} 
necessárias, além da reflexão filosóficas, posturas artísticas de pendor realista. O fim do governo de Díaz Ordaz (1964 - 1970) colocou em evidência a falência dos projetos que legitimavam a estrutura centralizadora e hierárquica do poder, representado pelo PRI. Com a assunção do cargo de chefe do executivo federal por Luís Echeverría Álvarez (1970 - 1976), deveriam interpor-se reformas importantes e de grande alcance em todos os âmbitos.

Não foi coincidência o surgimento, nesse período, de um ensaio de Daniel Cosío Villegas (1972/1974) analisando a forma de organização política. El sistema político mexicano: las posibilidades de cambio foi reformulado dois anos depois da primeira edição, porque Echeverría propôs alterações significativas nos principais documentos do PRI. ${ }^{91}$ Cosío Villegas aponta problemas singulares do sistema político àquela altura. O principal deles era a centralização "absoluta" (aspas do autor) dos poderes nas mãos do presidente da república. A consequência era uma dicotomia: sem ser um regime ditatorial e tendo a declaração expressa de um regime democrático na constituição de 1917, entre o fim da Revolução e o início dos anos 70, verdadeiramente, o sistema não era nem uma ditatura nem uma democracia.

Além de mexer nos estatutos do Partido, Echeverría realizou mudanças em diversos âmbitos, não obstante na prática a ação tenha sido mais tímida do que prometera na campanha (SALDÍVAR, 1980). Reformulações políticas, fiscais e sociais realizaramse em meio ao diálogo frequente tanto com líderes sindicais quanto com empresários. A aproximação e a mediação entre as classes antípodas do sistema capitalista se faziam urgentes porque os indicadores de desemprego aumentavam na proporção inversa aos do PIB. Saldívar (p. 118) argumenta que, apesar de no início do governo de Luis Echeverría a taxa de desemprego ser de $3,8 \%$, estimativas apontam que ela poderia chegar a $7 \%$. Além disso, o subemprego estava por volta de $45 \%$ dos trabalhadores, pois ganhavam menos que o salário-mínimo. Por outro lado, o PIB mexicano, que ultrapassou a média dos países da América Latina entre 1941 e 1965 (COSÍO VILLEGAS, 1974, p. 51-52) diminuía gradativamente. Portanto, fica evidente que se iniciava a deterioração das ações econômicas adotadas até então.

Esses dados, que por si só servem de sintoma da guinada sofrida pela análise dos fatores culturais e políticos do país, demonstram que as preocupações filosóficas da

\footnotetext{
${ }^{91}$ As mudanças foram forjadas, primeiro, em uma Assembleia Nacional de 1971 e, outra, em 1972, quando se reescreveram documentos fundacionais como a declaração de princípios, o programa de ação e os estatutos.
} 
metade dos anos 1950 podem ter contribuído para a mudança de atuação intelectual. Se na geração que vivenciara o período revolucionário o tom didático da produção ensaiava a missão formativa, não seria exagero pensar que o mergulho nos problemas mais profundos da existência mexicana para encontrar a essência humana tenha impulsionado a elaboração artítico-intelectual a apostar na missão combativa.

Essa visão do todo poderá nos auxiliar a verificar as transformações no campo teatral.

\subsection{Por uma dramaturgia do documento}

Vários críticos reconhecem a inovação promovida por Vicente Leñero ao inserir técnicas do teatro documental na dramaturgia mexicana. Tanto aqueles que podem hoje observar o fenômeno à distância, como Partida Tayzan (2002b), quanto outros que resenharam as representações de Pueblo rechazado (1968) e Los albañiles (1969), destacam os méritos positivos da empreitada de Leñero em uma dramaturgia que até o surgimento dessas duas peças estava apegada aos princípios aristotélicos, tal como fora ensinado por Usigli. Esse reconhecimento, no entanto, constantemente atribui a inovação apenas ao "gênio" do artista. Além disso, os estudos acerca de suas obras dramáticas recorrem quase sempre a seu sentimento religioso catolicista. Com efeito, esperamos neste instante lançar novas luzes à abordagem do teatro do autor de El juicio (1971) e tantas outras peças documentais significativas que abriram caminho para a geração dos anos 80 e 90 e, talvez até para os princípios da mais potente vertente da dramaturgia contemporânea, a do Norte.

A perspectiva existencialista com que os filósofos de Hiperión e outros pensadores vasculhavam os aspectos mais relevantes da sociedade e da cultura paulatinamente esmoreceu frente à realidade concreta. A partir de 1968, conflitos sociais, crises de legitimidade política e abalos na estrutura econômica favoreceram o surgimento de expressões artísticas de temperamento engajado e vertente realista.

Vicente Leñero é um dos escritores e intelectuais que assume essa perspectiva nos romances, contos e, principalmente, na dramaturgia, sem, no entanto, abandonar a dimensão mais profunda do ser humano. Suas personagens com frequência vivem estas duas tendências da arte em meados do século XX: a intimista e a engajada. 
Inseridas em contextos opressores (Pueblo rechazado) e outros de escassos recursos materiais (Los albañiles e Nadie sabe nada), as personagens comunicam conflitos pessoais, psicológicos, enfim, existenciais. Por esse motivo, abundam cenas de longas falas individuais; outras vezes, brotam solilóquios de profunda humanidade. Os dramas sofridos na individualidade, no entanto, emanam de situações cujos ambientes são determinantes para a manifestação de forças sociais contraditórias, mas sem cair no fácil maniqueísmo sociologizante.

Se, por um lado, a geração de dramaturgos imediatamente anterior, com Emilio Carballido e Sergio Magaña na proa, navegava por dramas de problemas culturais mais profundos (respectivamente: ;Silencio pollos peleones, ya les van a echar el maíz!, sobre a exploração do trabalho no campo, e El color de nuestra piel, acerca das divergências étnicas surgidas da presença camponesa e indígena na cidade), Leñero se dedica a temas mais imediatos. Decorre, então, a escolha pela "documentação" dos conflitos.

Nos bastidores do fenômeno teatral, verificamos que o financiamento e o aporte estatal à arte cai vertiginosamente. Mesmo assim, ao mesmo tempo o cenário cultural empenha-se em absorver as mudanças com o intuito de pôr à vista da população as mentiras e os conflitos de ordem política, social e econômica.

Podemos compreender o impacto desses fatores na vida artística pela observância do sistema dramatúrgico daquele momento. Inicialmente, são ilustrativas as opiniões registradas pelos jurados dos festivais de Primavera e de Verão, 1967 e 1968, respectivamente. Marcela del Río (sob o pseudônimo de Mara Reyes) reproduziu, em sua coluna semanal do jornal Excélsior, Diorama Teatral, as atas das comissões julgadoras, das quais, aliás, foi integrante.

O festival de $1967^{92}$ teve como proposta a apresentação de obras mexicanas inéditas. Os prêmios, que incluíam dinheiro e curtas temporadas em alguns teatros com direito a $50 \%$ das entradas, foram oferecidos pelo Instituto Mexicano de Seguridad Social (IMSS), pela UNAM e pelo INBA. ${ }^{93} \mathrm{Na}$ ata constou, entre outras, a recomendação de que fosse criado após o festival um Seminário de Dramaturgia com a finalidade de "capacitar técnicamente a los escritores que deseen dedicarse a la literatura dramática". Após a

\footnotetext{
${ }^{92} \mathrm{http} / / / \mathrm{www} \cdot$ resenahistoricateatromexico2021.net/proyecto_default.php?id=324\&op=1\&texto_palabra=1 967

${ }^{93} \mathrm{O}$ fato de que os subsídios e os impulsos artísticos de teatro e cinema fossem promovidos pelo governo leva Cosío Villegas (1974) a indagar se não haveria uma censura prévia. Para ele, a opinião pública se expressa por meio desses objetos culturais.
} 
reprodução desse documento, Reyes (1968) complementa e analisa alguns pontos das opiniões emitidas. Reforça a necessidade de capacitar melhor os autores por meio de oficinas, porque, "varias obras estaban fincadas en una idea interesante, en algunos casos bien planteada, pero que por falta de conocimientos de composición dramática del autor, fallaba el desarrollo y el tratamiento de ella". Na continuação, explicita as falhas dos dramaturgos das obras representadas.

O registro da comissão julgadora do Festival de Primavera de 1968 também é reproduzido pela crítica e dramaturga, que fora ainda integrante do comitê selecionador das obras a serem apresentadas. $\mathrm{O}$ julgamento inicial emitido pela comissão manifestava o desejo de

Expresar que la baja calidad de la mayoría de las obras participantes en este Festival ha dificultado la labor del Jurado en lo relativo a la elección de los autores dignos de que se les atribuyan los premios que establece el punto SEXTO de la Convocatoria.

O segundo tópico não é menos impactante:

[Recomienda] al Departamento de Teatro del INBA que en las próximas convocatorias de los festivales que organiza no se establezca la cláusula que impide declarar desiertos los premios para los autores, con objeto de dejar al Jurado libertad de exigir mayor nivel en la calidad de las obras y en todo caso actuar con mayor justicia. (REYES, $1968, \mathrm{~s} / \mathrm{p})$.

A análise das atas desses dois festivais possibilita a reflexão sobre os parâmetros de qualidade estipulados pelos críticos que integram as comissões julgadoras. ${ }^{94}$ Coloca-se, então, um questionamento: estariam os jurados esperando profundas inovações ou ainda desejavam que as obras atendessem aos modelos em voga? Como não é possível ter acesso às representações e tampouco conseguimos encontrar outras notas ou resenhas sobre elas, arriscamos uma opinião a partir de um pequeno vestígio. No caso do festival de 68, o júri, que além de Marcela del Río contava com Antonio Magaña Esquivel como presidente, Malkah Rabell, Benjamín Villanueva y Alejandro Luna, apesar de considerar que não havia qualidade nas apresentações,

\footnotetext{
${ }^{94}$ Caso semelhante havia acontecido já no início da década de 60. Em crônica sobre José Emilio Pacheco ("Anécdotas y recuento"), Margo Glantz (2007) conta en passant a experiência que viveu, ao lado dele e de China Mendonza, na comissão julgadora de um concurso promovido pelo INBA. Confessa que participaram nomes como Emilio Carballido, Sergio Magaña e Salvador Novo, mas, para surpresa dos jurados, o prêmio foi atribuído a um anônimo. Ao final desse pequeno episódio, faz a seguinte reflexão: "¿Qué había pasado?, nos preguntamos: una de dos, o éramos pésimos como jurado o los dramaturgos en cuestión habían dejado de ser buenos." (p. 12). A distância atual permite-nos afirmar que havia sinais de esgotamento da tradição iniciada por Usigli.
} 
outorgou o prêmio de melhor diretor, autor, bem como o prêmio especial Celestino Gorostiza a Willebaldo López por sua obra Cosas de muchachos.

Willebaldo López, com cerca de 24 anos e que também fora condecorado no festival de 1967, tornou-se, ao longo do tempo, um dos autores mais representativos da Nova Dramaturgia. Nas palavras de Armando Partida (que o classifica entre os "precursores" da Nova Dramaturgia ao lado de Maruxa Vilalta e Vicente Leñero), podemos considerar a peça Los arrieros con sus burros por la hermosa capital "como una de las primeras en abandonar el modelo usigliano aristotélico, por seguir el modelo de acción dramática muy próximo al del drama social.” (2002b, p. 17). Portanto, podemos inferir que, embora a comissão julgadora tenha manifestado a vontade de declarar desertos os prêmios, reconheceu, pela até então modesta amostra do criador de Yo soy Juárez (1972), que algo novo se desenhava — ou precisava se desenhar.

Outro aspecto que merece atenção no que diz respeito ao contexto em que surgiram as primeiras obras de Vicente Leñero é a sintomática presença de peças estrangeiras. Na terceira parte de seu "Balance anual del teatro en México en 1967", publicado em 24 de dezembro, na coluna de Excélsior, Marcela del Río registra que no Teatro Julio Jiménez Rueda, responsabilidade do INBA, das 17 estreias, 7 eram de autores estrangeiros. Ainda como parte da programação desse Teatro, Héctor Azar havia levado uma companhia alemã e, em parceria com a embaixada italiana, um grupo de Genova aportara no palco do Palacio de Bellas Artes.

Compuseram ainda a vida teatral do DF obras de dramaturgos como a norteamericana Ira Wallach, o polaco Slawomir Mrozek e o alemão Heinar Kipphardt ${ }^{95}$, entre outros. A presença de obras estrangeiras é sintomática. Estabelecendo uma comparação com o ocorrido durante as primeiras décadas do século, poderíamos levantar a hipótese de que a ausência de autores nacionais se tratava de uma tentativa de apresentar ao país o melhor do que se produzia fora do território mexicano. Porém, uma análise mais apurada, que considera o que sucedeu depois, mostra ter, na verdade, havido um esgotamento da vertente cimentada por Usigli e consagrada por seus continuadores dos anos 50.

\footnotetext{
${ }^{95}$ Além das obras dramáticas, o musical inglês de Leslie Bricusse e Anthony Newley, Parem o mundo que eu quero descer, também esteve presente.

REYES, Balance anual de teatro en México en 1967 - II. Disponível em: $<$ http://www.resenahistoricateatromexico2021.net/proyecto_default.php?id=341\&op=1\&texto_palabra=1 967>.
} 
Relacionado a essa presença de autores estrangeiros, podemos dar ênfase a um novo aspecto, muito relevante. Friedrich Dürrenmatt, Heinar Kipphardt ${ }^{96}$ e Bertolt Brecht, com Galileu Galilei, estiveram em cartaz em 1967, ao lado de Emilio Carballido, Rafael Solana e Hugo Argüelles. Já para 1968, Peter Weiss teve encenadas as peças Marat/Sade (com direção de Juan Ibáñez e tradução de Margo Glantz) e A ti, hombre... Brecht também foi encenado mais uma vez com A alma boa de Setsuan. Além dos consagrados nomes da dramaturgia europeia, Liberdade, Liberdade, de Millôr Fernandes e Flávio Rangel, integrou o Festival de Verão desse ano. Todas essas obras têm em comum a forma épica e documental. Percebemos, em uma análise curta de dois anos, 67 e 68, o quanto aumentou o número de obras de cunho político na vida teatral da capital.

Portanto, quando tentamos compreender as transformações da dramaturgia mexicana na década de 70 e a importância da forma teatral que Vicente Leñero consagrou e pela qual foi consagrado, é mister considerar o impacto dos eventos sociais, históricos, econômicos e culturais em um todo articulado. $\mathrm{O}$ teatro documental nos moldes como ele o concebeu e desenvolveu é, a nosso ver, além de fruto do gênio do artista que por ter conseguido conciliar a vertente intimista da arte com a engajada, ação premente do contexto em que vivia seu país. Dessa forma, o uso do documento para compor uma arte essencialmente marcada pela fugacidade do acontecimento simboliza o fazer histórico imediato. Esse não seria, então, o motivo que o leva a, paulatinamente, unir teatro documental ao histórico? É um dos aspectos que pretendemos verificar com a análise das obras a seguir.

\subsubsection{Pueblo rechazado}

Essa primeira obra dramática é fruto de uma experiência de confinamento. Para finalizar o romance Los albañiles, o autor se refugiou no mosteiro beneditino de Santa María de la Resurrección, em Cuernavaca, cujo sacerdote fundador, Gregorio Lemercier, utilizava desde 1961, sob consentimento do bispo Sergio Arceo Méndez, o método psicanalítico com os monges e os candidatos à vida religiosa. Poucos anos depois, o padre foi duramente criticado pela imprensa e pela Igreja por usar essa ciência no contexto religioso. A convivência com os monges e a experiência no jornalismo

\footnotetext{
${ }^{96}$ A primeira peça de teatro documental a estrear na Cidade do México foi In the case of J. Robert Oppenheimer, de Kipphardt, justamente no ano em que o caso de Gregorio Lemercier veio a público, isto é, 1961. (HOLZAPFEL, 1976).
} 
conduziram a concepção de Pueblo rechazado (1968/TC I) ${ }^{97}$. O título foi extraído de uma das declarações que o padre Lemercier deu à imprensa ao explicar as razões e o nome da nova ordem fundada depois que se desvinculou da Igreja Católica, Emaús (que em hebraico significa justamente "povo rejeitado"). Em sua estrutura, estão presentes, além das notícias que circularam pela imprensa, os registros do processo desenvolvido em Roma.

A Revista de la Universidad (editada pela UNAM) publicou a primeira edição no número 9, volume XXII, em maio do ano de estreia. O diretor da revista, Gastón García Cantú, elaborou aquele número com a finalidade de apresentar algumas vertentes mais atuais da literatura mexicana. Já a primeira montagem realizou-se em novembro do mesmo ano, quando Leñero estava na Europa sob o patrocínio de uma bolsa Guggenheim. A direção foi feita por Ignacio Retes e permaneceu em cartaz um longo tempo no teatro Xola.

Trata-se de uma "Pieza en dos actos", mas sem divisão de cenas. Aliás, as ações parecem antes desenvolver-se em quadros. As personagens estão indicadas apenas por sua função social: Prior, Analista, Obispo, Cardeais 1, 2 e 3; bem como por sua coletividade, os coros de Católicos, Jornalistas e Psicanalistas. Elementos simples compõem o cenário, o que permite indicar diferentes lugares dentro do mesmo espaço. No centro, há uma mesa de madeira que serve tanto de escrivaninha quanto de altar. Em alguns momentos, são mostrados os aposentos dos monges e, apesar de a maior parte das ações acontecer no mosteiro, no segundo ato, quando se realiza o concílio para o julgamento do Prior, como os cardeais se posicionam mais ao fundo, infere-se que estão em outro espaço — provavelmente a Santa Sé.

Embora as indicações de tempo não sejam dadas objetivamente, sabemos, em determinado momento, que "Freud morreu há 25 anos" e que em dezesseis de julho de 1961 a Igreja havia publicado um monitum aconselhando que não se usasse a Psicanálise nos mosteiros. Por último, o veredito do julgamento informa que é dia de São Venâncio (18 de maio). Todas as datas são condizentes com a história do padre belga Gregorio Lemercier.

No que tange às ações, é plenamente perceptível a ausência de um encadeamento causal entre os acontecimentos. Mantém-se a estrutura clássica, com apresentação, conflito e desfecho, mas a passagem dos quadros quase nunca possuiu uma

\footnotetext{
${ }^{97}$ Para referenciar as obras de Leñero no corpo do texto, usaremos TC (Teatro Completo), seguido pelo numeral romano I ou II, conforme o caso.
} 
relação de causa e efeito. Ao fazer a transição da apresentação para o conflito, no primeiro ato, por exemplo, é apresentada inicialmente a atmosfera em que vive o mosteiro. Por meio de pequenos quadros, observa-se a dimensão da vida cotidiana e do que se consideram enfermidades psicológicas aos olhos da Igreja. Isso é mostrado pelo Prior, que caminha de "celda" em "celda". Depois, dirige-se ao centro do cenário, que é invadido por "relámpagos luminosos" e onde "círculos y figuras cromáticas danzan en torno al prior". De repente, sob gritos do Prior que evocam a Deus, surge o Analista, visto por ele como “un ser sobrenatural, diabólico”. (TC I, p. 16).

Em linhas gerais, assim está armada Pueblo rechazado. A peça, mesmo tendo partido de um acontecimento situado no tempo, em um caso particular, tem uma dimensão universal. A luta do Prior ultrapassa a defesa institucional de seu mosteiro e do direito de realizar, com seus membros, os métodos da Psicanálise. O que vemos é um homem em conflito existencial, buscando uma fé verdadeira, uma causa mais transcendente do que a submissão aos dogmas institucionais. O Prior é um homem atormentado porque, como membro da Igreja Católica, sente que apenas os dogmas não bastam para compreender os monges nem os livrar dos fantasmas da mente e do espírito. A atribulação aumenta porque o mundo exterior, a própria Igreja, a imprensa, os psicanalistas e os fiéis - todos reprodutores do discurso da primeira - são contrários a seus métodos.

Esse conflito existencial, que se projeta no palco por meio de recursos cênicos geradores de uma atmosfera fantástica e pelos solilóquios do Prior, possibilita colocar em pauta o surgimento de uma nova forma de dramaturgia? Esse questionamento tem o propósito de abrir um caminho alternativo para as intepretações cujo foco é a dimensão religiosa de Leñero; interpretações tão comuns que, em muitos casos, fazem apenas indicar a identificação do autor aos princípios católicos. Na leitura que apresentamos aqui, pretendemos verificar em que medida essa peça cria caminhos para modificações estéticas do teatro mexicano quando um de seus mais respeitados renovadores, Rodolfo Usigli, ainda estava atuante e possuía seguidores, bem como discutir em que medida o argumento escolhido por Leñero dialoga com questões histórico-culturais.

Pela exposição panorâmica que fizemos anteriormente, identificamos um corte em relação aos dramas "anti-históricos" de Usigli: enquanto nas obras do autor de El gesticulador estava clara a intenção de tratar da história do México, em Pueblo rechazado, apesar de ter sido um evento conhecido no momento em que foi escrita, nada indica a princípio a reflexão sobre "uma questão mexicana". Na descrição do cenário, por 
exemplo, em nenhum momento se faz referência a Cuernava. A tensão histórica, na verdade, é colocada no contexto das reformas produzidas pelo Concílio Vaticano II.

Para se ter uma dimensão da importância da peça, uma análise do discurso do próprio Leñero no relato oferecido em Vivir del teatro (2012) pode colaborar sobremaneira. Em determinado momento, ao contar a empolgação do diretor Ignacio Retes e do produtor Enrique Lizalde com o sucesso de público, o dramaturgo opina o seguinte:

Como en aquel tiempo no estaba familiarizado aún con la excedida vanidad de la gente de teatro que la lleva a convertir los éxitos locales en triunfos históricos y a culpar de los fracasos a circunstancias externas, aquellos comentarios sobre el estreno de Pueblo rechazado me envanecieron de pronto. ¿Era posible tamaña gloria? (LEÑERO, 2012, p. 33).

Ainda que aplique vestígios de modéstia, o aqui memorialista Vicente Leñero reconhece, nas entrelinhas, o importante papel de sua primeira peça. Ao longo do relato, em que conta uma espécie de périplo para conseguir montar a obra, pontua pouco a pouco a vida teatral do DF. Todos os diretores de teatro e atores que procura para apresentá-la estavam envolvidos em projetos de dramas estrangeiros. Relata Leñero que o primeiro deles, Ramón Xirau, ponderou o oportunismo da proposta. Portanto, que a deixasse descansar, e por fim, aconselhou que procurasse José Luis Ibáñez, quem interpretou a peça como sendo um auto sacramental muito mal construído, pois não seguia as regras do gênero. O próprio Leñero, disposto já a abandonar o projeto, ganhou novo fôlego ao assistir Galileu Galilei, de Brecht, sob a direção de Ignacio Retes, que seria, ao fim, o responsável por articular a montagem com Enrique Lizalde. No episódio em que conta o encontro com o diretor para a montagem fica explícita a predominância de peças estrangeiras: Retes, que estava atuando em $O$ jardim das cerejeiras, sob direção de Dagoberto Guillamin, foi ao jantar oferecido na casa do famoso ator Ignacio López Tarso, que havia sido dirigido por Retes em Un tigre a las puertas, de Giraudoux, Otelo e Édipo Rei, e estava por decidir trabalhar com Alejandro Jodorowsky em El rey se mиеre, de Ionesco. As palavras da esposa de López Tarso ao marido, reproduzidas por Leñero, dão a dimensão da importância de Pueblo rechazado para aquele contexto: "Ya es tiempo de que vuelvas a hacer teatro mexicano." (LEÑERO, 2012, p. 26).

Apresentado esse panorama introdutório, passamos a discutir os elementos afins aos propósitos deste trabalho, a saber, aqueles que articulam a relação entre literatura 
e história no contexto da dramaturgia mexicana do século XX. Em Pueblo rechazado, destacaremos o papel dos elementos historicizantes, ou seja, épicos.

O próprio Vicente Leñero nos informa os documentos em que se apoiou para escrever a peça:

utilicé el Padrenuestro reproducido en su libro [de Lemercier] Dialogues avec le Christ para la escena de la misa, y fragmentos de su homilia Trente ans perché sur un sycomore para los monólogos del Prior. Algunos otros documentos, como la intervención de Méndez Arceo durante el concilio, como declaraciones de Lemercier en sus entrevistas con Luis Suárez y como las opiniones de los monjes aparecidas en un reportaje de Robert Serrou en Paris-Match, entraron a formar parte de la obra impunemente saqueados. (LEÑERO, 2012, p.23).

A multiplicidade das fontes corrobora para ampliar o conflito, uma vez que o autor se preocupou em oferecer a visão e a atuação dos diferentes núcleos de poder em tensão no evento representado.

Do ponto de vista da contextualização, Leñero preocupou-se em não reduzir a ação a um acontecimento localizado. Por isso, inclusive, a generalização dos actantes: o Prior não se chama Gregorio Lemercier, o Analista não é Gustavo Quevedo nem o bispo é Méndez Arceo. Os coros também auxiliam na extrapolação do conflito para além do local e do tempo imediato em que aconteceu.

Além desses elementos, a apropriação dos textos jornalísticos como processo de reescrita mostra as diferenças entre o artista documental, o historiador imediatista e o jornalista. Enquanto os dois últimos motivam-se pela explicação do factual, o que torna artístico o trabalho é a capacidade de extrapolar esse limite. Nesse sentido, o documento, mesmo sendo responsável por assentar a historicidade do acontecimento e ancorar a trama no verossímil, é dotado de uma significação atemporal.

As implicações estéticas decorrentes da seleção e da organização dos documentos parecem se afastar do diálogo com a história, pois, como dissemos, nada em Pueblo rechazado nos indica a priori tratar-se de uma obra mexicana. Os lugares e os nomes das personagens têm tratamento genérico. Essa ausência de um referente especificamente mexicano nos motiva a questionar as estratégias de representação da nação. Embora saibamos, pelas informações do autor e da fortuna crítica, que o enredo se originou de um evento localizado no México, é possível ampliar a leitura questionando, por exemplo, os sentimentos e os abalos psicológicos experimentados pelo Prior, o embate entre religião e ciência e a representação dos problemas decorrentes do 
confinamento religioso. Como, portanto, reconhecer o "histórico" enquanto categoria de análise literária conforme expusemos no primeiro capítulo deste trabalho?

Como é particular às obras arquitetadas sobre documentos, a leitura exige o reconhecimento da intertextualidade. E, embora o autor tenha explicitado suas fontes e princípios de composição, a fortuna crítica da obra elaborou seus pilares apenas sobre essa sinalização. Acreditamos, assim, que é preciso lançar-se não à procura das pistas que explicam o conjunto da obra, mas refletir sobre a postura política, motivação de primeira ordem do teatro documental.

Sabemos que o ano de publicação da peça, 1968, é emblemático devido aos acontecimentos da praça de Tlatelolco. $\mathrm{O}$ aprofundamento nas questões históricas mostra ainda que esse ano representa o fim do "milagre mexicano", assim chamado o período iniciado na década de 40 que se caracterizou por avanço econômico, urbanização, desenvolvimento da exploração petrolífera, êxodo rural e ampliação da oferta educativa. O interessante é perceber que todos os benefícios experimentados no período eram atribuídos à Revolução. Havia, portanto, um processo histórico que se legitimava pelas conquistas posteriores, mesmo que ele já houvesse dado sinais de enfraquecimento, entre outros motivos, pela permanência das estruturas de poder.

A emergência de uma arte dramática que substituía o resgate de acontecimentos e figuras históricas emblemáticas para a construção da nação por uma perspectiva de problematização dessa história e de seus heróis deve ser entendida nesse contexto de uma nova crise sócio-política. Na substituição da história mais remota pela imediata, se lembrarmos que o autor era jornalista, não teremos dificuldade em compreender como a dramaturgia mexicana ganha com essa nova vertente.

Apesar disso, Pueblo rechazado coloca no centro de suas preocupações uma das mais fortes características da vida, da história e da formação identitária mexicanas: a religiosidade cristã católica. O visitante que caminha pelo DF, Puebla ou Toluca, por exemplo, sente-se totalmente envolto pela proteção divina. Esbarramos em igrejas, santuários e mosteiros a cada esquina que dobramos. A imagem da Virgem de Guadalupe nos acompanha onde quer que estejamos: no táxi, na entrada e na cozinha de "hostels", nas bancas de jornal, nos camelôs, na rodoviária, nos ônibus clandestinos. Como não ver na própria forma responsorial ("para servirle”) de nossas "muchas gracias" ecos de princípio cristão? (Talvez um antropólogo mais engajado veja nessa expressão a permanência de processos de opressão...) Sabemos ainda o quanto a riqueza artísticocultural do país é fruto do mundo católico. Os dogmas, é preciso dizê-lo, comparecem no 
imaginário como forças extraordinárias porque foram capazes de subjugar um grande Império, ainda que hoje saibamos quanto horror e erro houve naquele processo.

Voltando ao contexto histórico em que a peça foi escrita, encontraremos que, além dos problemas político-sociais vividos pelo México, acontecia o Concílio Vaticano II, no qual se produziram mudanças significativas na Igreja Católica. O próprio ritual da missa foi modificado: a desobrigação do uso do véu para mulheres, a retirada da cerca que separava assembleia e altar, a possibilidade de que padre e público se olhassem face a face e, certamente o mais impactante, a celebração na língua materna da comunidade. Todas essas alterações não passam despercebidas dos católicos leigos. Para bem e para mal.

Deve ser observado outro aspecto: as divergências entre a Igreja e o Estado desde a Colonização. Para nos restringirmos ao século XX, basta lembrar a forma como a Igreja foi tratada durante a Revolução e o conflito posterior, a guerra cristera (19261929). Nos anos 50, a instituição aproximou-se dos problemas das classes operárias, camponesas, educativas e políticas. Administrou as Cajas Populares, órgãos cuja finalidade era o empréstimo de dinheiro aos mais necessitados a juros baixos para evitar que fossem coagidos por agiotas. Impulsionou também a criação de cooperativas agropecuárias, centros sociais e os de capacitação técnica, agrícola e industrial.

Ainda no mesmo período, a América Latina foi promulgada Terra de Missões pelo Papa João XXIII, o mesmo que convocou o Concílio Vaticano II. Com o fim de se consolidar esse propósito, desencadeou-se uma migração para os países do continente. No México, o fluxo de missionários foi menor porque já havia mais religiosos, em termos de proporcionalidade, do que em outros países. Apesar disso, no princípio dos anos 60 foram criadas em Cuernavaca, ponto irradiador do conflito representado por Vicente Leñero, instituições ${ }^{98}$ que centralizaram as correntes pastorais, teológicas, ecumênicas e litúrgicas do pré-concílio.

Embora não tenha havido resistências às mudanças propostas pelo Vaticano, na prática houve dificuldades para inseri-las. Maria Martha Pacheco Hinojosa (2005) aponta que entre as dificuldades havia o privilégio do culto em detrimento da edificação social, a falta de atualização teológica, a dependência do clero para a organização comunitária e a ausência de diálogo da Igreja com a sociedade.

\footnotetext{
${ }^{98}$ As instituições são o Centro Interamericano de Documentação (CIDOC), Centro Interamericano Cultural e o Centro Pastoral para Latinoamérica.
} 
As dificuldades de aplicação das ideias do Concílio no país são refiguradas nos conflitos entre os Coros na peça de Vicente Leñero. Logo na abertura da obra, enquanto o Sacerdote conduz o Coro de Católicos pelo mosteiro, o grupo tem uma postura favorável ao Prior, inclusive com euforia:

CORO DE CATÓLICOS (avanzando hacia él, efusivos): Dios lo bendiga, padre, Dios lo premie. Ha realizado usted una obra maravillosa. Su monasterio es una escuela de fe. Una fuente de espiritualidad. De sabiduría. De gracia. Dios los bendiga, padre. (LEÑERO, TC I, p. 13).

Essa postura se mantém inclusive diante dos Jornalistas. Uma das movimentações que comprova a adesão à iniciativa é quando, em meio aos questionamentos ao Prior e à própria Igreja, o Coro de Católicos procura impor silêncio com um ruído sibilante: "Shhhhhh”. Esse gesto significa, a um só tempo, a reprodução imitativa do que fizera o Sacerdote no início da ação tão logo adentraram ao mosteiro e o conflito com a opinião pública, representada pelos Jornalistas. Porém, à medida que a própria Igreja questiona a intromissão da psicanálise entre os monges, postura seguida inclusive pelo próprio Sacerdote, os Católicos mudam de opinião. A alteração fica evidente no trecho a seguir. Após os Jornalistas, eufóricos, perceberem vestígios de notícia, o Sacerdote expõe a posição da instituição:

SACERDOTE (después de imponer silencio, doctoral): Los criterios infalibles de la Iglesia no admiten discusión. En un valioso diccionario de teología moral se afirma, de manera tajante: Difícilmente podemos excusar de pecado mortal a quien libre y conscientemente adopta y se somete al psicoanálisis.

CORO DE PERIODISTAS: ;Oooooh!

CORO DE CATÓLICOS: Pecado mortal. ¡Pecado mortal! ¡Condenación eterna! (p. 23)

Após a condenação do Prior, a mudança se acentua. O Coro de Católicos quer ouvir da imprensa palavras duras contra ele, as mesmas lançadas contra aquele que, no início, haviam elogiado:

CORO DE CATÓLICOS: El prior no es Galileo. El prior no es un iluminado. El prior es un rebelde. El prior es un hereje. El prior es un apóstata, blasfemo, miserable. ¡Hace doscientos años lo hubiéramos quemado! ¡Qué se diga toda la verdad!

CORO DE PERIODISTAS: ¡Yo la sé, yo la sé!

CORO DE CATÓLICOS: Que hable el periodismo.

CORO DE PERIODISTAS: El monasterio es un centro de depravación.

Una cueva de enfermos sexuales.

CORO DE CATÓLICOS: Enfermos, herejes, traidores. (p. 45) 
Nesses trechos, as mudanças nas maneiras de agir da Igreja - e, consequentemente, no aspecto religioso da cultura mexicana - se conjugam à série de incertezas da vida social, política e econômica com o fim do milagre mexicano (quer dizer, com os efeitos benéficos da Revolução). Fica evidente que a absorção, pela coletividade e pela opinião pública, da condenação ao Prior e ao mosteiro tem bases nas alterações de rumo da Igreja. Como, então, pensar um país, e sua nacionalidade, se dois de seus principais pilares, a história e religião, estavam sendo abaladas?

Assim, com a escolha do caso Gregorio Lemercier para iniciar sua vida de dramaturgo de teatro documental, Leñero esboçava uma novidade no que tange as relações da dramaturgia com a história. Parecia que a obra sinalizava para a necessidade de uma imersão nas estruturas do imaginário popular-nacional e não apenas para o resgate de fatos marcantes do passado nacional. Porém, essa abertura para a exploração de uma nova estratégia de ficcionalidade paulatinamente se volta para a imersão nos acontecimentos pretéritos.

A verificação das implicações estéticas e temáticas que a retomada de fatos históricos remotos em substituição aos imediatos provoca na dramaturgia poderá ser mais aprofundada a partir da análise de uma das peças em que se realiza o processo. Para isso, apresentamos a seguir a reescrita dos acontecimentos que marcaram os últimos dias de um herói nacional, José María Morelos y Pavón.

\subsubsection{Martirio de Morelos}

Com essa peça, Vicente Leñero inicia uma forma alternativa para o drama histórico tradicional. Ela se afasta da imersão na história imediata na proporção em que recorre a um evento mais distante no tempo: o julgamento do líder da Independência do México. Por outro lado, os recursos técnicos se assemelham muito àqueles típicos do teatro documental. A observância da conjunção de dois gêneros dramáticos (o documental e o histórico) implica a operacionalização de dois procedimentos analíticos. Um deles deve estar mais voltado à compreensão do evento histórico representado, enquanto o outro busca, na estrutura organizacional da ação, compreender os efeitos de sentido resultantes dos recursos de documentação. 
Quando cotejada com a obra que analisamos anteriormente, Martirio de Morelos (1981/TC I) apresenta pontos diferentes no que diz respeito à abordagem social e ao tratamento estético. Ainda que a presença documental ancore a ação na realidade, certos recursos cênicos abrem espaço para uma atmosfera mais "absurda", abstrata, onírica. De fato, a universalidade que o dramaturgo pretendeu dar à primeira é conquistada nesta por meio de recursos que procuram afastar a representação da estética realista.

Com efeito, apesar de nosso interesse não recair diretamente no debate acerca da (re)significação do movimento de Independência do México, vamos rememorar alguns episódios e personagens para depois passar à análise da obra sob a perspectiva da apropriação de um tema histórico com fim de metateatralidade, pois, conforme apontados acima, o fato de haver vestígios de um drama histórico tradicional exige que partamos dele para chegar a enxergar mais nitidamente as alterações da dramaturgia dos anos 70.

José María Morelos y Pavón (1765 - 1815) foi um clérigo nascido na cidade de Valladolid (Nueva España), hoje Morelia, capital do Estado de Michoacán. Depois de sua ordenação, foi pároco na cidade de Curácuaro. Entre os anos de estudo e a nomeação para o cargo, começam as ações insurgentes a favor da independência lideradas por outro padre, Miguel Hidalgo y Costilla. Em outubro de 1810, ocorre o encontro de Morelos e Hidalgo na cidade natal do primeiro ${ }^{99}$.

Com a captura de Hidalgo em março e seu fuzilamento em agosto de 1811, Morelos assumiu lugar de destaque nas lutas independentistas, entre outros motivos, por suas manobras militares. Além da capacidade de liderança nas batalhas, com a criação da Suprema Junta Nacional de América em novembro do mesmo ano da morte de Hidalgo, deu mostras de grande habilidade para estabelecer os princípios ideológicos do governo que pretendia formar após a independência

Durante o período das batalhas, Morelos manteve uma extensa correspondência com líderes de outros estados e com integrantes de seu grupo, tais como o jurista Ignacio López Rayón. Em 1813, por exemplo, apresentou uma proposta de

\footnotetext{
${ }^{99}$ Existe uma extensa discussão acerca desse encontro. Historiadores mais antigos como Carlos María Bustamante defendem que Morelos já estava planejando a independência quando conheceu Hidalgo. Alejandro Villaseñor y Villaseñor elabora, a partir de uma carta que depois foi considerada falsa, uma suposta troca epistolar entre os padres. Para uma explicação dos movimentos interpretativos dessa parte da história, apoiamos-nos nas ponderações de Timmons (1985). Na obra de Leñero, a intenção de ingressar nas tropas é explicitamente pronunciada por Morelos à junta militar: "A principios de octubre de 1810 tuve las primeras noticias de la revolución de don Miguel Hidalgo. Supe que había tomado Valladollid, que andaba cerca de la zona, y decidí ir a buscarlo." (p. 599).
} 
constituição aos insurgentes reunidos em Chilpancingo para o Congresso de Anáhuac. Há ainda manifestos, como seu "breve razonamiento a sus conciudadanos", poucos dias antes daquela reunião. ${ }^{100}$

A prisão de Morelos ocorreu em novembro de 1815, em Tesmalaca, durante uma das viagens que o Congresso fazia para não ser capturado pelas tropas reais. $\mathrm{O}$ esquadrão real estava sob o comando do tenente Matías Carranco, "que había servido en las tropas de Morelos en Acapulco y en Cuautla" (TIMMONS, 1985, p. 154). Capturado, o líder da insurreição foi acusado de traição, deslealdade ao rei (Fernando VII, que, no início da revolução, via sua Espanha subjugada pelas tropas francesas de Napoleão) e promoção da independência. A acusação fez com que Morelos passasse por três processos, o da Junta Unida, formada pelo clero e por militares, o do Poder Real e o Inquisitorial, que queria condená-lo por heresia. A sentença condenatória desta última determinou que ele passasse por um auto de fé (o qual expõe o herege à comunidade). Além disso, Morelos foi fuzilado em San Cristóbal Ecatepec no dia 22 de dezembro de 1815.

Todo o processo judicial está muito bem documentado ${ }^{101}$ e foi aproveitado por Vicente Leñero. A primeira edição de Martirio de Morelos foi publicada em novembro 1981 por Seix Barral. Nela, havia notas explicativas que sinalizavam para os documentos utilizados pelo autor, segundo nos indicam Arizmendi et al (2002). O dramaturgo conta em Vivir del teatro (2012) que suas bases documentais foram também os livros publicados em 1927 pela Secretaria de Educação Pública, os quais “contenían documentos medulares de la historia del caudillo" e "el tomo VI de la Colección de Hernández y Dávalos" (p. 228). Dessa coleção, interessam-lhe as atas dos processos, sobretudo porque nelas está registrado um Morelos que, nas palavras de Timmons (1985, p. 160), "empezó a flaquear" e "a revelar información militar" porque "desde ese momento [de la condenación inquisitorial] [...] se sentía profundamente preocupado con la salvación de su alma." A representação de um Morelos arrependido, temeroso de sua condenação é recuperada por Leñero.

\footnotetext{
${ }^{100}$ Fartas são as publicações dos documentos desse período. Para este trabalho, tomamos alguns da Historia documental de México, organizada por Ernesto de la Torre Villar, Moisés González Navarro y Stanley Ross (1974). Sugerimos também os Autógrafos de Morelos y otros documentos, organizado pelo Tribunal Electoral del Poder Judicial de la Federación (2013) e a Antologia Documental Sentimientos de la nación de José María Morelos, publicado pelo Instituto Nacional de Estudios Históricos de las Revoluciones de México (2013), ambos facilmente encontráveis na internet.

101 Tivemos contato com esses documentos através da página web 500 años de México en documentos (www.biblioteca.tv). A plataforma recupera documentos que Genaro García organizou e que foram publicados pela editora Porrúa em 1975 e muitos outros.
} 
A diferença entre o Morelos das atas e o da história causou problemas para o autor. Problemas estéticos e políticos. Os estéticos são decorrentes do próprio princípio de construção do teatro documental, pois, segundo ele mesmo relata em Vivir del teatro,

desde el principio de mi investigación tuve el convencimiento de que las actas eran genuinas y traducían el verdadero comportamiento de Morelos durante sus procesos, pero desde luego esto es imposible de demostrar. Como tampoco se puede demostrar que durante los interrogatorios Morelos respondía una cosa y el escribano o los jefes del escribano redactaban otra. Sea como fuere, la obra que terminé escribiendo reproduce los documentos tal como llegaron a nosotros y no se detiene a discutir qué tan genuinos o qué tan amañados fueron registrados en 1815. (LENEERO, 2012, p. 228-229).

O problema político ocorreu em 1982 com a montagem do diretor Luis de Tavira. No ano anterior, Morelos havia sido o emblema da campanha eleitoral do então Secretario de Gobernación y Presupuesto, Miguel de la Madrid Hurtado, que assumiu a presidência em dezembro de $1982 .{ }^{102} \mathrm{O}$ conflito decorre da contradição entre o Morelos idealizado e exaltado como herói nacional e o da peça, pois Martirio de Morelos põe em cena a captura desse herói que, em julgamento, parece sentir medo.

Na peça, a ação se concentra na prisão em Tezmalaca ${ }^{103}$, os julgamentos civil, militar, religioso e inquisitorial e o fuzilamento em Ecatepec, eventos ocorridos entre cinco de novembro e vinte e dois de dezembro de 1815. A peça está dividida em duas partes que contém, cada uma, três “capítulos" 104 , correspondentes à captura, aos processos e ao fuzilamento. Na primeira parte também existe um Prólogo.

Em todas as partes há um rol de personagens indicados por sua função social no contexto das lutas pela independência mexicana (Virrey, Auditor de la Jurisdicción, Eclesiástico, Defensor 1 e 2 etc.) seguido de seu nome entre parêntese (Félix María Calleja, Miguel Bataller, Félix Flores Alatorre, José María Quiles y José María Rozas, de acordo com os exemplos anteriores). Ao cotejar os nomes das personagens aos fatos históricos, identificamos os registros facilmente. Existem outras personagens não nomeadas, mas que não chegam a intervir diretamente na ação. $\mathrm{Na}$ verdade, são

\footnotetext{
102 Para o relato (além de esclarecedor, saborosíssimo) das lutas pela montagem, ver Vivir del teatro (2012, p. 226-256).

103 Mantemos a ortografia com "z", conforme utilizou Leñero na obra, ainda que atualmente a recomendação seja pelo uso do "s".

${ }^{104}$ Dois motivos nos levam a preferir o termo "capítulo" no lugar de "cenas". Inicialmente, porque as subdivisões das partes possuem títulos: "La aprehensión", "Proceso de la jurisdicción Unida", "Proceso del Santo Oficio", "Auto de fe", "Proceso de la jurisdicción militar" e "La pena de muerte". Além disso, a construção do cenário (com seu atril e um grande livro) nos convoca a identificar mais os diversos elementos prosaicos narrativos que os teatrais como quadros ou cenas.
} 
personagens coletivas bastante comuns no teatro épico, tais como "Soldados realistas", "Pobladores de la región" e "Civiles y políticos". A única "personagem" fíccional é o Leitor, que participa em momentos específicos e cuja interação é mais constante com Morelos. Dentro dos propósitos de nosso trabalho, é essa personagem que adquire substancial importância, pois é por meio dela que a obra ultrapassa o modo tradicional do drama histórico.

O cenário é singelo e, simultaneamente, onírico, porquanto, ao mesmo tempo em que deve ser "escueto, casi vacío", destaca-se, no "proscenio, un gran atril que soporta un libro de enormes dimensiones" (LEÑERO, TC I, 546).

A divisão estrutural em duas partes e um prólogo, a presença de uma personagem alegórica (Leitor) e o cenário dividido explicitamente em dois, criam uma atmosfera que nos ajuda a ver dois eixos de ação na obra. Em um deles (que chamaremos histórico), são representadas as etapas correspondentes à divisão das duas partes, ou seja, se trata de mostrar, de pôr em cena, de fazer presente de novo, os últimos dias de José María Morelos. Outro eixo (que denominamos metateatral) é desenvolvido na interação do protagonista e o Vice-Rei com o Leitor. Essas duas linhas de ação auxiliam na compreensão tanto das rupturas com o teatro histórico convencional quanto com a elaboração reescritural enquanto metateatralidade.

Quando a peça se inicia, Morelos ocupa o proscênio, em direção ao Livro ${ }^{105}$, o folheia "como si lo hiciera casualmente" (p. 546). É interpelado pelo Leitor, que, depois de algumas palavras, reconhece seu interlocutor. Sem confirmar sua identidade ao Leitor, Morelos quer saber o que está escrito a seu respeito no Livro. É informado que seu nome está nele e "en cientos, en miles de páginas, de párrafos, de frases [...] biografías exhaustivas, estudios históricos [...] monumentos y estatuas [...] un estado de la República lleva su nombre [...] y hasta en monedas"; fica sabendo também dos epítetos atribuídos a ele.

A personagem se mostra surpresa e confusa ao mesmo tempo, pois não reconhece nada do que é dito pelo interlocutor. Sua principal dúvida é saber se foi perdoado por seu país e pela história. Surpreende-se também ao saber que esta última o registra como mártir. Frente à resposta do Leitor de que para a história não há dúvidas sobre sua coragem e importância, o revolucionário se mostra contrário ao que o

\footnotetext{
105 Devido às enormes dimensões e à importância na ação, utilizaremos a letra maiúscula quando nomeemos o livro, ainda que o registro na edição utilizada seja sempre em minúscula.
} 
interlocutor anuncia. Então, procura convencê-lo de que viveu um martírio ao qual não resistiu e finaliza, expressando-se em terceira pessoa:

No, no lo resistió... El fin se precipitó de golpe como un terremoto. Fue demasiado para su ánimo herido en las últimas batallas: derrota tras derrota; debilitado por tantas disputas entre sus compañeros insurgentes; sumido en la desesperanza... Quedó solo frente al enemigo. Abandonado en un campo de batalla que no era el suyo, sin armas para la lucha... (p. 548).

Em síntese, o que se vê no Prólogo é um Morelos que hesita, que se sente culpado, desenganado pela história, ainda que o Leitor, a todo instante, lendo trechos do Livro, busque confirmar que está equivocado. O conflito de Martirio de Morelos nasce, então, da contradição entre aquilo que está registrado e aquilo que o protagonista sente.

Seguem, então, a re-presentação, a nova vivência do passado, a prisão, os processos, a condenação por heresia e o fuzilamento, ou seja, os últimos dias do estadista. Nesse instante, se instaura uma dicotomia entre o enunciado (que, aliás, está registrado no Livro) e a enunciação de Morelos. Essa dicotomia é a marca da iminência de uma dupla temporalidade: o presente da encenação e o passado. Nota-se a duplicidade inclusive no protagonista, pois o Morelos que interage com o Leitor movimenta-se entre o presente e o passado.

A tensão provocada pela não identificação dos sentimentos de Morelos e o relato histórico é confirmada em diversos momentos da obra. O Leitor, sem assumir uma opinião pessoal, reproduz os registros, até mesmo nos momentos em que Morelos interage com outras personagens. Durante o Processo da Junta Militar, ele sintetiza os fatos que deveriam ser relatados por Morelos e condensa as palavras do interrogatório:

MILITAR: Detallada, señor Morelos; lo más detallada [de las acciones insurgentes] que le sea posible.

Morelos habla ante el tribunal, pero su voz resulta ahora inaudible. Sustituye a su relato, lo abrevia, el parlamento del lector.

LECTOR (leyendo): Amplia, prolijamente, Morelos describió ante la Jurisdicción Militar sus campañas guerreras. Cómo salió de Curácuaro con sólo veinticinco hombres y llegó al Aguacatillo, antes de iniciar... (p. 600).

Nesse trecho, manifesta-se um efeito semelhante ao distanciamento brechtiano. O Leitor, assumindo a função de "narrador" que historiciza os fatos, rompe o avançar do evento representado cenicamente para problematizar os acontecimentos em si 
mesmos e o próprio registro histórico. Em outras palavras, o passado mostrado na representação é substituído pela reflexão sobre ele feita a partir do presente.

A tensão entre os acontecimentos e as temporalidades é aprofundada pelo uso do documento para a montagem. Nos momentos do enunciado, ou seja, da representação do julgamento de Morelos, a base dos diálogos é formada pelos documentos mais díspares, sobretudo as atas dos interrogatórios, as quais são modificadas sutilmente. ${ }^{106}$ Entretanto, nos momentos da enunciação, os textos lidos pelo Leitor não são extraídos de livros de história. Os registros "reais" (os documentos) são mostrados como ficção e a ficção (trechos enunciados em forma de leitura pelo Leitor) é exposta como real. O que vemos, portanto, é uma estratégia de Vicente Leñero para problematizar não somente a história e a figura de Morelos, mas também a própria concepção de teatro documental como gênero.

No final da obra, depois que Morelos já está morto, predomina a realidade em detrimento da ficção. O Vice-rei exige que o Leitor leia um documento que o historiador Lucas Alamán teria trazido à luz em 1851. A discussão que se estabelece é sobre a veracidade da autoria. O Leitor, pela primeira vez tomando partido na situação, declara que considera espúrio o documento. Trata-se de uma suposta retratação que Morelos teria escrito em 10 de dezembro de 1815.

O desfecho da obra com a leitura do polêmico documento provoca outra vez a desconstrução da imagem assumida no imaginário mexicano, anunciada e explicada pelo Leitor no Prólogo. Expõe também o importante papel exercido pelo dramaturgo de teatro documental ao levantar as tensões e os problemas de uma nação. A exposição desse documento (além da veracidade de sua autoria) é importante como forma de contestação da própria historiografia, pois no Livro a retratação está colocada em "una nota a pie de página, muy pasada. No se concede importancia al documento" que foi inclusive considerado inautêntico por Lucas Alamán, "un historiador al que no puede acusarse de parcialidad a favor de los insurgentes" (p. 616). ${ }^{107}$

\footnotetext{
${ }^{106}$ Um exemplo da manipulação do texto ocorre na fala do Militar ao Vice-rei (ausente da cena). Leñero utiliza trechos que Manuel de la Concha enviou a Calleja em 13 de novembro de 1815. Já nas primeiras linhas, o militar escreve que fez uma perseguição "continuada al rebelde Morelos que con su gavilla marchaba por el margen del río...". (DE LA CONCHA, s/p). Ao reescrever, Leñero troca "gavilla" por "cuadrilla". A mudança é uma adaptação ao tempo em que a peça foi escrita, mas não de sentido: "una persecución continuada al rebelde Morelos que con su cuadrilla marchaba por la margen del río..." (LEÑERO, ano, p. 549). Outra mudança que se percebe é o uso do artigo masculino como determinante de "margen" na carta de Manuel de la Concha e o feminino por Vicente Leñero. Não há, contudo, nesses casos, nenhum efeito além da atualização gramatical.

${ }^{107}$ Wilbert H. Timmons, em sua biografia de Morelos, confirma a opinião de Alamán: "Esta retractación parece totalmente increíble, y hasta Alamán la puso en duda.” (TIMMONS, 1985, p. 164).
} 
Ao estabelecerem-se essas dicotomias, podemos agora esclarecer nossa leitura de Martirio de Morelos, a qual tenta demonstrar que o uso da história é um recurso metateatral. Utilizamos para isso o modelo actancial desenvolvido por Anne Ubersfeld (2005) em Para ler o teatro I. Como sabemos, ela propõe que a análise de textos dramáticos seja vista a partir de um sistema composto por seis elementos: Destinador (D1), Destinatário (D2), Sujeito (S), Objeto (O), Adjuvante (A) e Oponente (Op) ${ }^{108}$, assim ilustrado:

D1
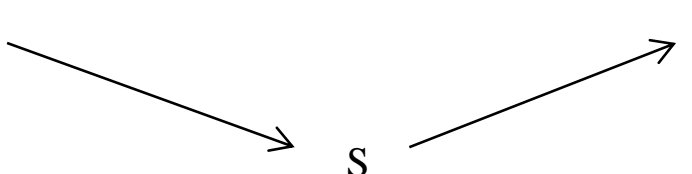

D2

A

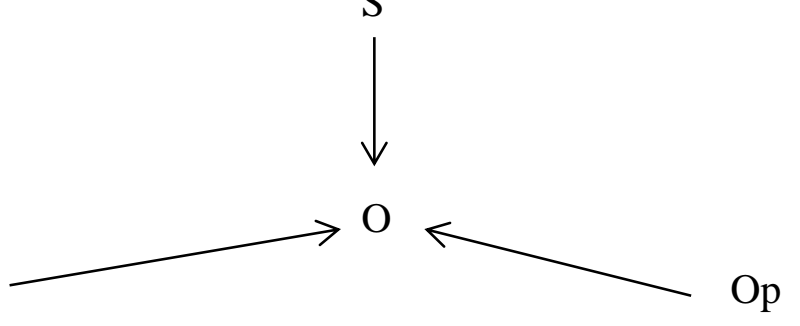

Não é nossa intenção explicar ponto a ponto o modelo, uma vez que é muito conhecido e que, segundo a própria autora, não deve ser visto como algo fixo. Ademais, os exemplos utilizados por Ubersfeld são todos do teatro clássico, cuja característica é justamente a mímesis, isto é, a intenção de mobilizar o talento individual a partir de uma forma fixa e de certas regras de composição. Todavia, a escolha desse sistema nos mantém em nosso objetivo de pensar a própria construção do julgamento de Morelos.

Ubersfeld (p. 50) reconhece a possibilidade de que uma obra contenha mais de um modelo actancial: "talvez possa afirmar que [...], no teatro, não somos confrontados com um único modelo actancial, mas com pelo menos dois." (itálico da autora). Mais adiante, complementa: “também é possível, na representação, deixar subsistirem os dois modelos actanciais, fazer um e o outro representarem, mostrá-los

\footnotetext{
${ }^{108}$ A proposta de Ubersfeld (2005) difere daquele que Patrice Pavis utiliza em Le théâtre contemporain (2011), ainda que ambos partam do modelo actancial de Greimas e mantenham os elementos. Porém, Pavis defende que Adjuvante e Oponente indicam passagem por obstáculos do Sujeito e que Destinador e Destinatário se dirigem ao Objeto. Preferimos o modelo de Ubersfeld porque, primeiro, ela reconhece as possibilidades de nuances e, mais importante, porque nos parece que Pavis (2011) se contradiz ao dizer que o Destinador é a "motivação da personagem" para o Objeto e, ao mesmo tempo, que há uma "linha contínua da ação e sequência de ações físicas" do Sujeito em direção ao Objeto. Dessa forma, poderíamos perguntar se Sujeito (motivado pelo Adjuvante) e Opositor motivam o Objeto, por que existiria o Destinador?
} 
imbricados um no outro com suas possibilidades conflituais e com sua concorrência." (p. $51)$.

Antes de passar aos modelos possíveis en Martirio de Morelos, necessitamos lembrar uma última questão. De acordo com Ubersfeld (p. 37), não é preciso que todos os elementos estejam presentes em todas as obras: "Notemos que a possibilidade de casas vazias jamais está descartada", explica exatamente a autora.

Por isso, ao pensar na ação dramática da obra de Vicente Leñero aqui analisada, identificamos o seguinte:

Eixo actancial 1 - O histórico

Leitor (D1)

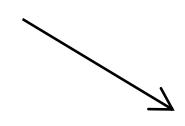

As Juntas(S)

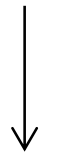

Os documentos $(\mathrm{A}) \longrightarrow \operatorname{Morelos}(\mathrm{O})$ A história (Op)

Nesse eixo temos a representação do evento histórico "Julgamento de Morelos", isto é, o fato consagrado pela historiografia do qual parte Vicente Leñero. As Juntas Unida, do Santo Oficio e Militar objetivam condenar Morelos, ainda que por motivos diferentes. Contudo, é necessário afirmar que esse fato histórico é motivado, na peça, a partir da conversação inicial entre Morelos e o Leitor. Então, devemos elaborar outro modelo actancial (que corre em paralelo):

Eixo Actancial 2 - O metateatral

A história (D1) $\longrightarrow \quad \operatorname{Morelos}(\mathrm{S})$

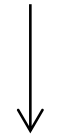

Os documentos $(\mathrm{A}) \longrightarrow$ Leitor $(\mathrm{O})$ 
Nesse esquema, Morelos é o Sujeito da ação porque pretende saber como sua biografia está registrada no Livro. O Leitor não oferece nada além das opiniões que constam nos documentos. A história é o Destinador, quer dizer, o motor da ação dramática.

Portanto, nos parece plausível afirmar que há um imbricamento dos modelos, o que nos conduz exatamente à metateatralidade que tínhamos como hipótese de análise da peça. Morelos é Sujeito e Objeto da ação. O Leitor, parte fundamental no processo da metateatralidade, é Destinador e Objeto. Segundo as palavras de Ubersfeld (p. 39), o D1 contém em si mesmo a significação ideológica do texto dramático porque é um elemento do exterior. Simultaneamente, é o responsável por mobilizar o Sujeito. Portanto, vemos que na dupla posição ocupada por um e outro se produz uma circularidade que é muito semelhante ao procedimento autorreferencial típico do teatro no teatro, isto é, o movimento que a obra faz de se voltar para si mesma ou de pôr em cena uma representação que se reconheça como teatral.

\subsection{Pensar é reescrever a história?}

Para a literatura, o documento histórico tem várias funções. Serve à ancoragem no real, à verossimilhança e ao oferecimento de um enredo completo (começo, meio e fim) com todos os elementos narrativos (personagens, tempo, espaço etc). Em nível mais profundo, tem a função de problematizar o evento em si e o processo de escrita, bem como de lançar dúvida sobre o que se conta a partir da contraposição da forma realista com a realidade. Para uma nação cuja História tanto se enraíza na conversa cotidiana e na mais alta reflexão filosófica, lançar mão do documento, questionando-o, é também condenar a historiografia oficial, a memória coletiva e o imaginário nacional. $\mathrm{O}$ evento histórico, nesse sentido, é uma metáfora ou alegoria de um sentir nacional.

Na dramaturgia de Vicente Leñero, a subversão da história não acontece pela modificação do ponto de vista nem por centralizar a ação em personagens coadjuvantes - explorados em certa medida por Usigli. Além disso, as personagens coletivas, tão exploradas pelo teatro de matriz épica, cede cada vez mais espaço aos protagonistas da história, que viverão, na cena, não os conflitos do momento em que as ações acontecem, mas as ideias abstratas que seus sucessores, isto é, os cidadãos de um tempo que, para as personagens, é futuro e que é contemporâneo para o autor, leitor / espectador, atores e diretor. 
Podemos, a partir dessas constatações, explicitar o que entendemos, no âmbito deste trabalho, por "história pensada", do tipo que Leñero promove com seu teatro. Trata-se de uma expressão discursiva de eventos históricos que visa a observar com restrições e desconfiança os documentos que testemunham, registram ou interpretam esses eventos. A forma ficcional predomina nesse modo de experiência histórica porque põe à prova os acontecimentos e os registros documentais, mas sem abrir mão deles. Nessa forma de apresentação dos fatos pretéritos, subjaz uma maturação reflexiva que a antecede e pressupõe que a sua exposição seja feita de uma maneira em que se desvelem as contradições, os pontos de divergência, as questões conflituosas, enfim, os aspectos sobre os quais se refletiu e que serviram não para a interpretação da história, mas para a elaboração ficcional. Subentende-se, portanto, que pensar a história difere de conhecê-la ou descobri-la.

Vicente Leñero logra promover a inovação dramática porque nunca se contenta com a apresentação unilateral dos fatos. Os recursos que criam o efeito de problematização da história são, principalmente, a inserção de vários documentos, inclusive divergentes, a adoção de múltiplas perspectivas espaciais e o jogo temporal entre o presente da enunciação e a representação do enunciado. Contribuem ainda significativamente para a história enquanto objeto pensado o fato de as diferentes versões dos eventos serem contadas, primeiro, por personagens com diferentes objetivos, e, mais profundamente, por personas coletivas e abstratas. Os Coros ou as designações genéricas de um grupo social, profissional, religioso etc. incorporam discursos desautorizados, no sentido de que não tem autoria. Esses discursos, assim como os provérbios, ditados, frases prontas, elaborados como máximas, tendem a captar a adesão do público justamente pelo caráter de massa. Por outro lado, a presença de personagens como o Leitor instiga a noção de que algo verdadeiro se encontra sob os olhos, porquanto não parte de uma voz, de uma persona interessada.

Dessa forma, o sentido de reescrever a história vincula-se à sua face mais elementar: escrever de novo, contar novamente. Não se modificam os agentes nem os actantes dos eventos sobre os quais se debruça, mas se desconfia da identificação fiel entre discurso verbal e realidade extratextual.

Por isso, o documento, no contexto em que irrompe a obra dramática de Leñero, é símbolo do desejo pelo registro imediato e multifacetado dos acontecimentos. Registrar é um ato de resistência. Os que registram, os que pautam a criação artística e a ação política pelo registro exercem a função de testemunhas e historiadores de uma 
sociedade em conflito. Desse modo, a inscrição dos fatos em um suporte oferece visões diferentes ao mesmo tempo em que promove o reconhecimento do evento para as gerações futuras. Portanto, pensar a história não é a reescrita, mas o alargamento da paisagem que se escreve e do momento em que se inscreve.

O maior beneficiário dessa problematização da história, porém, não é a historiografia nem a memória coletiva. A ficção literária, que ao longo dos séculos passou pelo princípio da imitação e do desejo de criar no leitor / espectador um efeito o mais próximo da realidade possível, consegue aprimorar técnicas, expandir recursos e encontrar-se consigo. 


\section{Capítulo 5 - Sabina Berman: A história ressignificada}

Sabina Berman, filha de imigrantes de origem judia, nasceu em 1955, na Cidade do México. Cursou Psicologia e Letras Mexicanas ao mesmo tempo, na Universidade Ibero-americana, onde chegou a receber uma bolsa para frequentar a oficina de poesia da Capilla Alfonsina, a casa cultural de Alfonso Reyes. Permaneceu ali um ano e meio, lendo e escutando, explicando e debatendo os poemas que escrevia.

Durante esses mesmos anos, ligada ao teatro de Héctor Azar no CADAC (Centro de Arte Dramático AC), se inscreveu em um concurso organizado pela Universidade, cuja proposta consistia em produzir um drama que durasse até doze minutos. Assim veio à luz a primeira peça, Mariposa, vencedora do certâmen, com a qual pôde viajar por cidades de província, acompanhando as apresentações.

Terminados os estudos universitários, no final dos anos 1970 realizou estágio em um hospital psiquiátrico onde, conforme confessou a Francine A’Ness (2004, p. 47), começou "a dudar de eso que se llama 'realidad' [...] desde la percepción de la realidad hasta las convenciones que mantienen esa percepción de la realidad, desde el lenguaje que mantiene esa percepción hasta y a cosas más elaboradas como la construcción de la historia."

As experiências teatrais desses anos de formação se intensificaram quando conheceu o diretor Abraham Oceransky, de quem foi companheira durante nove anos e quem lhe sugeriu o ingresso nas oficinas de criação dramatúrgica ministradas por Hugo Argüelles. Desse aprendizado, surgiu uma das primeiras obras expressivas de sua carreira, Bill - Yankee, de 1979. Desde então, a trajetória artística de Sabina Berman tem sido marcada por premiações, sucesso de público, homenagens, e oscilações da crítica especializada.

Berman é uma artista que lapida e reelabora frequentemente suas peças. Um exemplo impressionante é En el nombre de Dios, que se intitulou originalmente Anatema, depois Los Carbajales, e ainda Marranos. Em 1985, foi publicada com o título de Herejía, mas em 1996, estreou no Teatro Reforma com o título hoje fixado no livro Puro teatro (2004) como En el nombre de Dios. Para a dramaturga, a reescrita e a volta a um mesmo tema é um processo semelhante ao de um pintor cuja obra passa por várias etapas até chegar ao quadro que o consagra. ${ }^{109}$

\footnotetext{
${ }^{109}$ Ideia expressa na entrevista que nos concedeu em maio de 2016.
} 
Esse empenho com as obras teatrais se coaduna com a personalidade artística profícua, pois, além da dramaturgia, produz e dirige tanto peças quanto obras cinematográficas. Em meados dos anos 1990, empreendeu, junto com Isabelle Tardán, a produção de Entre Villa y una mujer desnuda. Depois, o argumento foi transposto para o cinema, também sob roteiro e direção da própria autora. Somam-se à atuação nessas áreas, a publicação de dois romances La bobe (1990) e La mujer que buceó dentro del corazón del mundo (2011), bem como a apresentação de um talkshow na Televisão Azteca Trece. Mesmo tendo excursões pelo romance, pela biografia e pelo jornalismo (através da crítica política), opinamos que é no teatro que seu fazer literário se realiza mais plenamente.

Essa atuação multimidiática às vezes rende críticas de que seus dramas são uma espécie de "teatro light" (PARTIDA TAYZAN, 2002a, p. 191). A verdade é que Berman tem clara consciência da diferença que existe entre o teatro de elaboração mais acurada e aquele mais comercial. A montagem de suas obras tem expressivo sucesso desde Entre Villa y una mujer desnuda, com destaque para Feliz nuevo siglo, doktor Freud, que chegou a duzentas apresentações, entre 2000 e 2002. Nos Estados Unidos peças têm alcançado êxitos semelhantes aos do México.

\subsection{Redefinição do nacionalismo no século XX e XXI}

Para a discussão sobre a identidade mexicana que se relaciona com o contexto de Sabina Berman, devemos esclarecer que não rastreamos as manifestações nacionalistas em si, à maneira como fazem, por exemplo, Jacques F. Lafaye em Quetzalcóatl y Guadalupe (1992), David Brading em Los orígenes del nacionalismo mexicano (1991) e Peggy K. Liss em Orígenes de la nacionalidad mexicana, 1521 - 1556 (1986). ${ }^{110}$ Como fizemos já nos capítulos antecendentes, nosso propósito é traçar um histórico sintético dos ensaios de intepretação identitária ao longo do século XX. Em suma, podemos dizer que, além de sempre recorrerem à história e interpretarem pontos de sua cultura, o que marca o trabalho dos ensaístas do nosso corpus — José Vasconcelos, Samuel Ramos, os

\footnotetext{
${ }^{110}$ É interessante notar que nessas obras o nacionalismo localiza-se nos primeiros contatos com os europeus, ou seja, um ponto remoto do passado mexicano. Assim, um traço diferenciador do que estamos realizando em todo este trabalho é a ênfase em um período relativamente recente. Neste capítulo, em especial, escolhemos um estudo sobre a Revolução porque este evento carrega uma enorme carga simbólica do ponto de vista da valorização dos elementos autóctones dentro da história do país.
} 
chamados hiperiones, Octavio Paz e Daniel Cosío Villegas — é uma perspectiva crítica dos próprios elementos culturais que analisam.

Já avançado o século XX, no umbral do XXI, percebemos que o México integra o conjunto de nações não hegemônicas que enfrenta dificuldades para conciliar a valorização dos elementos autóctones, tradicionais, típicos (e até mesmo estereotípicos) com o sistema transnacional de circulação da economia, das ideias e dos bens de consumo cultural. Fala-se, nesse contexto, de multinacionalismos e multiculturalismos; ao mesmo tempo, de globalização. Hoje as reflexões e os estudos que abordam esses problemas são incontáveis, dentro e fora do México. Fernando Vizcaíno Guerra, autor do livro El nacionalismo mexicano en los tiempos de la globalización y el multiculturalismo (2004) apresenta uma profunda investigação não apenas do estágio atual do sentimento nacional em seu país, mas também uma série de dados acerca das manifestações nacionalistas nas décadas finais do século XX e nas primeiras do XXI.

O estudo caracteriza-se pela postura extremadamente metódica. Não se trata mais de interpretações e reflexões especulativas sobre a identidade e o nacionalismo, como acontecia com os intérpretes anteriores. Agora, conceitos e categorias das ciências humanas e sociais aplicadas são trabalhados a fim de se construir um texto em que as conjecturas cedem espaço para a análise de documentos e dados estatísticos.

Outra marca fundamental está no foco do autor. Preocupa-se com o nacionalismo de Estado, ou seja, com as estratégias que o poder representativo utiliza para provocar legitimidade e identidade entre suas decisões e o povo. Esse aspecto, aliás, é um tanto controverso dentro dos estudos sobre nacionalismo. Conforme explica o próprio Vizcaíno Guerra (p. 11):

Hasta hace algunos años, predominó la idea de que la condición esencial del nacionalismo era el Estado. Gellner (1983) y Hobsbawm (1991), entre otros, difundieron esta tesis. Hablar de nacionalismo implicaba decir nacionalismo de Estado. A partir de finales de los años setenta, en cambio, comenzó a ganar importancia la tesis según la cual la condición fundamental del nacionalismo era la nación, no el Estado (Smith, 1983). Tal concepción transformó la teoría y se aceptó la existencia de innumerables movimientos etnonacionalistas. ${ }^{111}$

\footnotetext{
${ }^{111}$ As obras dos autores referenciados no trecho são as seguintes: de Hobsbawn, Nações e nacionalismo desde 1780, de Gellner, Nações e nacionalismos e de Adam Smith, Theories of nationalism. Praticamente as mesmas em que nos baseamos para abrir o capítulo 1 desta tese.
} 
Costuma-se estipular que o ingresso dos países periféricos no processo de globalização aconteceu por volta da década de 1990. No entanto, baseado em outros antecedentes, Vizcaíno Guerra localiza nos anos 70 o início de uma nova expressão nacionalista por parte do Estado, já que as negociações para o ingresso do México na Organização Mundial de Comércio (OMC) teriam começado em $1974^{112}$. Nessa mesma década, conforme ele argumenta, o número de acordos internacionais assinados pelo México teria crescido de forma expressiva, "de manera que la integración internacional de los noventa es una ratificación de una tendencia iniciada dos décadas atrás." (p. 12).

A partir do governo de Carlos Salinas de Gortari (1988-1994), a tendência se consolidadaria, simultaneamente a transformações significativas na legislação interna: o reconhecimento das múltiplas etnicidades por meio da modificação do artigo IV da Constituição; o estabelecimento da Comissão Nacional de Direitos Humanos e a observação internacional nas eleições e seu controle pelos cidadãos. Tratava-se de um conjunto de ações que intervinham no território nacional sem excluir o contato com o exterior.

A análise da mudança na forma de expressar o nacionalismo é feita com dados quantitativos da recorrência de expressões ligadas à Revolução, em discursos oficiais dos chefes do executivo federal em um evento anual conhecido como "el día del informe". A cada primeiro de setembro, o presidente em exercício entrega um relatório de atividades e da situação do governo ao Congresso. Ainda que não seja obrigatória, é comum a leitura do documento para os parlamentares. Vizcaíno Guerra observa que já no primeiro relatório de Carlos Salinas de Gortari se detectava a diminuição do uso do dogma da Revolução como estratégia argumentativa para vincular o nacionalismo à história. Até aquele momento, os discursos e os documentos pautavam-se na grandeza do país impulsionada tanto por aquele evento quanto pela Independência.

A reviravolta discursiva teria acontecido quando Salinas de Gortari evidenciava a ideia de que o crescimento do Estado significava pobreza ou má distribuição da riqueza. Dessa constatação se passava à defesa da privatização de setores não estratégicos. Nesse sentido, então, ser nacionalista não significava trabalhar em função do fortalecimento estatal, mas pelo engrandecimento e desenvolvimento das pessoas. Isso explicaria, então, a criação de leis que, visando a "melhorar" a vida dos cidadãos, seriam promulgadas em favor das minorias e dos desfavorecidos. Por outro lado,

\footnotetext{
${ }^{112}$ Nesse ano, teriam começado as discussões para se integrar ao GATT, levadas adiante pelo então ministro da Fazenda, Lopez Portillo do PRI, que dois anos depois, seria o candidato único à Presidência.
} 
fortaleceu-se nesse período, a legislação legitimando a abertura aos mercados estrangeiros.

A mudança era substancial. No governo de Salinas, o episódio de 1910 deixa de ser um ideal em si mesmo, um ponto utópico a que se pretendia chegar, para se transformar no fundamento de novas ações governamentais. Essa apresentação do problema do nacionalismo feita por Vizcaíno Guerra nos concede algumas chaves importantes para compreender, do ponto de vista simbólico, o modo de operacionalizar o tempo na cultura mexicana. É singular o fato de que a Revolução, sendo um evento passado, paire no imaginário mais pelo que poderia ter acontecido do que por aquilo que verdadeiramente aconteceu. Esse efeito paradoxal da experiência do tempo está, também, na raiz da experiência estética proporcionada pelo teatro, já que passado e presente se sobrepõem, principalmente para o público, no momento da representação.

Na síntese do próprio Vizcaíno Guerra lemos:

Lo más destacado es que este ascenso del nacionalismo democrático y el descenso del nacionalismo revolucionario revelan, más que una estadística, un cambio cualitativo: un nuevo nacionalismo, en ciernes seguramente, en donde los valores fundamentales están asociados a la modernización de finales del siglo XX y principios del XXI. Este nacionalismo corresponde con la apertura al mundo, apertura económica y también política, la tolerancia y el reconocimiento de las minorías culturales. (p. 143)

O trecho em destaque pareceria contraditório: o nacionalismo expressa-se não pela valorização ou interiorização dos próprios elementos e costumes, mas pela abertura "ao mundo", ação necessária para o reconhecimento das minorias culturais. O vínculo que o México manteve com outras nações teria sido, antes de tudo, consequência da necessidade de legitimação e aceitação dos povos que mantinham suas tradições, mesmo em um cenário de política de unidade nacional. No entanto, Vizcaíno Guerra admite que os símbolos nacionais começaram a desaparecer tão logo se intensificou o processo de globalização. Em suas palavras:

...con la Revolución mexicana, el antiimperialismo, el proteccionismo económico, la industria "nacional" y la propiedad estatal se constituyeron en símbolos del nacionalismo. Empero, con la intensificación de las interconexiones globales comenzaron a desvanecerse esos símbolos. (p. 104 - aspas do autor).

Essa perspectiva é compartilhada por um historiador contemporâneo. Enrique Florescano (2009) coincide com a percepção de Vizcaíno Guerra no ensaio El nuevo 
pasado mexicano, em que defende que em fins dos anos 80 , dando sequência às teses revisionistas iniciadas na década anterior, começaram a surgir estudos de ressignificação dos mitos e heróis revolucionários. É o caso de livros como The myth of the revolution. Hero cults and the institutionalization of the Mexican state, 1920-1940 (1986), de Illene V. O’Malley, e La jaula de la melancolía (1987), de Roger Bartra.

Florescano mostra as principais teses fraturadas por esses estudos. A relação com os Estados Unidos (portanto, o olhar do mexicano frente ao estrangeiro considerado dominador) ocupa lugar primordial. Seu estudo demonstra que dados econômicofinanceiros das décadas de 70 e 80 colocaram em xeque a existência de uma prática de valorização nacional no período de 1910-1920. Segundo essa tese, o nacionalismo foi um fenômeno dos anos seguintes, 1920-1930, mais apegado ao discurso político e a algumas práticas culturais do que à prática governamental.

É verdade que as constatações de Vizcaíno Guerra e Florescano sobre o redimensionamento do valor simbólico da Revolução não foram, na historiografia e na história, as primeiras a sinalizar as consequências negativas do conflito. Ainda nos anos 20, muitos intelectuais exprimiram ressentimentos diante dos caminhos adversos que a política e a cultura iam tomando. Manuel Gómez Morin, “caudillo cultural” da Geração de 1915, e José Vasconcelos são alguns daqueles que, no calor da hora, se decepcionaram porque viram frustrar-se os projetos de construção nacional ${ }^{113}$. A diferença está a priori no fato destes últimos terem vivenciado o conflito. Sua decepção se misturava, muitas vezes, com amarguras pessoais. Já Vizcaíno Guerra quanto Florescano, distanciados temporalmente do acontecimento, se utilizam de ferramentas mais quantitativas e objetivas.

\subsection{Subversão da arte e da história}

Os paradoxos das expressões nacionalistas integram substancialmente a obra de Sabina Berman. Tanto as formas elaboradas pelo Estado quanto as manifestações do imaginário coletivo estão presentes enquanto tema a discutir, ponderar, problematizar e,

\footnotetext{
113 Para uma visão profunda dos sentimentos negativos que os rumos da Revolução imprimiram na mentalidade desses intelectuais que tanto apostaram na formação do país, recomendamos a leitura da "carta" que Gómez Morin escreveu, ao que parece, para extravasar a amargura com os regimes logo após saber, em Londres, da matança de Huitzilac, em 1927. O texto está reproduzido na íntegra em Caudillos culturales en la Revolución mexicana, de Enrique Krauze (1976/2014).
} 
sobretudo, ressignificar. Não raro, como veremos, sobressaem a ironia e o sarcasmo para denunciar o apego aos valores tradicionais e à história sem crítica. Não faltam estudos demonstrando o caráter "pós-moderno" do seu teatro. Interessa-nos demonstrar, no entanto, que nele estão em jogo os conflitos surgidos da reflexão sobre a história. Dessa forma, ser pós-moderna aparece como consequência dessa postura.

No primeiro livro dedicado integralmente à sua obra, Sediciosas seducciones (2004), o editor Edgar Ceballos destaca que uma peculiaridade da dramaturga é seu “atrevimiento por subvertir valores patrios, culturales, históricos y sexuales" (p. 11). Da mesma forma, a crítica norte-americana Jacqueline Bixler, compiladora do volume e uma das mais aprofundadas conhecedoras da obra, afirma que a autora é "una luchadora incansable en contra del establishment teatral, histórico, sexual y político de su país." (p. 17).

Declaradamente feminista, mas sem pretensão de escrever obras engajadas, conforme declarou em 1994 numa entrevista a Partida Tayzan (2002a), ela leva ao palco temas recorrentes do teatro mexicano, tais como a demagogia política. No entanto, um número expressivo de críticos, sobretudo norte-americanos, tem lido suas obras sob o signo das lutas de gênero. Realmente, leituras possíveis, porque naquelas de maior alcance de público e de crítica (Entre Villa y una mujer desnuda e Feliz nuevo siglo, doktor Freud), o tema do machismo está marcadamente presente. Ao mesmo tempo, percebemos que suas peças se ancoram em enredos históricos. A história ocupa, de fato, lugar preponderante nessa atitude atrevida da subversão dos valores, sobretudo nos primeiros escritos dos anos 1980. Em Rompecabezas, de 1981, o argumento foca o assassinato de Trotski. Dois anos depois, com En el nombre de Dios, dedicou-se a pensar a situação dos cripto-judeus na Nova Espanha, a partir da perseguição sofrida pela família Carbajal. Em 1985, montava Águila o sol, sobre a Conquista do México. Podemos ainda destacar a variedade de temas históricos nas peças de maturidade, tais como Entre Villa y una mujer desnuda, de 1994, Krísis, de 1996, e a peça infantil La maravillosa historia del Chiquito Pingüica, em que faz uma adaptação do Popo Vuh, estreada em 1990.

A recorrência aos temas históricos, porém, não segue as mesmas estratégias em todas as etapas criativas da autora. Nossa hipótese é que até fins dos anos 80 ela seleciona um evento consagrado pela historiografia e o refigura utilizando técnicas do Teatro do Absurdo e algumas do épico, com as quais consegue apresentar uma perspectiva mais problematizadora dos fatos. Com La grieta, escrita entre 1985 e 1987, conforme veremos a seguir, a história aparece, mas sem reelaboração de um evento 
específico. A partir de então, a seleção dos "fatos históricos" que compõem a arquitetura das peças parece pautar-se antes por aquilo que, no caudal dos acontecimentos recentes, carrega significados dos traços identitários e culturais do passado que julga negativos e que necessitam ser abandonados ou superados. Nesse sentido, ela promove um imbricamento entre história e imaginário que possibilita explorar estratégias ficcionais e cênicas que dão novo ritmo e cadência à dramaturgia e à encenação de seu país.

A seguir, passamos a analisar, em separado, as obras La grieta e Entre Villa y una mujer desnuda; depois, cotejando às peças de Usigli e Leñero sobre a Conquista, nos voltamos para Águila o sol.

\subsubsection{La grieta}

Nessa peça ${ }^{114}$, em que as técnicas de refiguração da história somam-se a procedimentos semelhantes aos do Teatro do Absurdo, a peculiaridade em relação aos primeiros dramas da autora (por exemplo, En el nombre de Dios, Rompecabezas e Bill) reside na abordagem metafórica e abstrata do(s) evento(s) histórico(s). As personagens e a ação, aqui, não nos remetem imediatamente a um acontecimento específico consagrado pela historiografia. De fato, nesse momento, a mudança que Le Goff (1992) chamaria de "revolução documental" entra de vez no processamento dos conhecimentos históricos com vistas à ficcionalização. Por isso, denominá-la drama histórico (nomenclatura ainda possível com relação às obras de Usigli e Leñero) não cabe mais. Além disso, apesar da exploração de múltiplas referências documentais, tampouco se poderia atribuir o nome de documental. De maneira geral, os quadros e certos signos evocam facilmente acontecimentos de um passado recente que, devido à sua fugacidade e pontualidade, não seriam considerados históricos no sentido dos grandes feitos, mas quando tecidos em conjunto revelam fragilidades políticas e práticas culturais recorrentes na história. Essa escolha provoca a sensação de continuidade dos desmazelos políticos e a impressão de

\footnotetext{
${ }^{114}$ A obra, que está dividida em dois atos sem indicações da mudança de cenas, parece ser a junção de dois dramas curtos: La antesala e La grieta. A biblioteca do Consejo Nacional de Artes da Cidade do México coloca à disposição um "libreto", ou seja, uma encadernação da cópia da peça distribuída aos atores nos ensaios, em cuja capa está claramente marcada a reelaboração. Anotou-se ali, com caneta piloto azul, o seguinte: "I — La antesala. II — La grieta: dos obras complementarias.” Infelizmente, não há data... Foi publicada em 1987 na revista Tramoya, mas teve a primeira montagem quase dez anos depois (1996) sob a direção de Carlos Haro. No que se refere à orientação das citações nesta tese, esclarecemos que seguimos a publicação de Puro teatro (2004) pela editora Fondo de Cultura Económica.
} 
que a estrutura perniciosa da história nacional como processo permanece igual na essência, mesmo havendo modificações das personagens no poder.

Dessa forma, La grieta representa um ponto de inflexão na dramaturgia mexicana porque explora acontecimentos imediatos aparentemente irrelevantes, que provavelmente passariam despercebidos devido à frequência cotidiana a ponto de parecerem automatizados. A constatação dessas permanências coloca em cena problemas sobre a possibilidade de se manter a noção de histórico quando, apesar das alterações, nada parece mudar. Disso decorre a problematização da forma como se estabelece o diálogo entre a obra ficcional e a história quando não existe um evento histórico reconhecível e sedimentado nos documentos. Nossa hipótese encaminha-se, então, no sentido de reconhecer que a inserção do imaginário, dos estereótipos, dos símbolos culturais encadeados a aspectos históricos propõe uma nova forma de imbricamento entre ficção e história no sistema dramatúrgico mexicano.

Os episódios imediatos e os símbolos culturais inserem-se em uma trama relativamente simples. Um jovem casal (Él e Ella, que se chama Fabiana, mas não tem essa indicação nas didascálias) recém-contratado para trabalhar em um escritório aguarda instruções das atividades que deve realizar. Não se sabe qual é a função; tampouco ficam claras as instruções. Com o avançar do tempo, sabemos que o emprego havia sido oferecido à moça pelo chefe do escritório (o Licenciado F) enquanto flertava com ela em um coquetel. O primeiro ato termina sem que saibamos quase nada das demais personagens: os Empleados 1 (Rodríguez) e 2 (Narváez) e o Invidente, irmão gêmeo do funcionário 2 - os quais devem, segundo a rubrica, ser interpretados pelo mesmo ator.

Ainda no primeiro ato, a descrição do cenário faz ver uma construção realista. O jovem casal está em uma antessala, com mesa, sofá, escrivaninha, vaso com plantas e uma TV. Ao fundo, existem três portas: A, B e C, e uma janela guilhotina. À medida que as personagens interagem entre si e com o cenário, o realismo se desfaz: o sofá passa a ser um "instrumento técnico impressionante" (pode se transformar em cama); a escrivaninha é usada como púlpito; as plantas propiciam oxigênio durante as sessões de ginástica que, de tempos em tempos, "unos labios muy sensuales" ministram de repente pela TV. Além da interação com esses objetos cenográficos de primeiro plano, a janela e o teto passam a ter papel protagonista, pois enquanto ela serve para a queda do Invidente e para decepar a cabeça do Licenciado F, ele desaba no final, em consequência de uma fissura que se expande paulatinamente e sem causa concreta aparente. 
Tudo isso se passa em mais ou menos vinte e quatro horas. Vemos que os Empleados saem para almoçar e voltam. Mais tarde, após o Licenciado anunciar o fím do expediente, o casal dorme no escritório e se encontra, pela manhã, com os três burocratas. A unidade concentrada da ação se contrapõe à rapidez com que se abre a fissura no teto. Os funcionários a veem, mas não se incomodam. Insistem em dizer que não se trata de uma "grieta", mas sim de uma "cuarteadura", mesmo reconhecendo que ela sempre estivera ali, que era apenas "un rayóncito".

Nessas cenas iniciais, os elementos espaciais e os objetos instigam a abordagem dos temas mais do que as movimentações e a gestualidade das personagens. O ambiente burocrático fechado, as escolhas entre A, B ou C (forma genérica de designar escolhas que são semelhantes) e o abalo da estrutura física do prédio são signos alegóricos da "micropolítica", isto é, dos bastidores do poder político. Isso fica evidente também no início da edição de que nos valemos. O paratexto inicial, que oscila entre prefácio e apresentação, sublinha o problema da mentira na política. ${ }^{115}$ No entanto, essa temática que, nas palavras de Hannah Arendt (2011), é tão antiga nas formas de governo do Ocidente, está aqui atrelada às implicações da modernização no contexto dos anos $80 .{ }^{116}$

Para compreender em que medida é possível analisar La grieta sob a perspectiva das relações entre o embuste governamental e o cenário modernizante, recorremos inicialmente às palavras do Licenciado $\mathrm{F}$ nos momentos que antecedem a sua morte/suicídio.

Quase no final do segundo ato, o casal e os funcionários sentam-se de frente para o chefe do escritório, que, num procedimento claramente metateatral, se coloca atrás da escrivaninha para fazer um discurso. Nada acontece de concreto (ou seja, em termos dramáticos, não há causalidade explícita entre essa cena e outra anterior) para que tome essa atitude; ele apenas anuncia que tem a sensação de estar sendo traído. As quatro personagens, assim, se tornam espectadoras. Em meio a interrupções, o Licenciado faz

\footnotetext{
115 Cosío Villegas (1974) definiu o sistema de governo de Porfirio Díaz como uma "política a portas fechadas", sobretudo quando se tratava de dirimir alguma divergência com a oposição. Durante a Revolução, os conflitos políticos ganhavam publicidade, porém, a sucessão presidencial a partir de 1928 retoma o sistema de acordos a portas fechadas, entre outros motivos, pela criação do partido único da revolução. Isso se aperfeiçoou a ponto de que em 1946 atingiu a forma mais bem-acabada: "desde entonces, la política mexicana, sobre todo en cuanto a lo que los politólogos gustan de llamar decision-making process, se convierte en um misterio poco menos que impenetrable." (p. 17). Essa nomenclatura pode ser seguramente tomada como sinônimo do "sistema de antessala" que Berman alegoriza e condena em La grieta.

${ }^{116}$ Embora o tema da mentira na política seja fulcral em nossa análise, acreditamos que não são menos pertinentes (antes estão articulados a ele) o conflito geracional, o esvaziamento do papel do intelectual na sociedade e a presença feminina no microcosmo social representado pelo escritório.
} 
um discurso sobre o devir, sobre o progresso, a modernidade etc. F não deixa claro em que consiste esse devir:

Señores... El futuro está delante nuestro. Pero el presente no. El presente... está... ¿dónde? El presente está... [...] El presente no está en ninguna parte... más que ;aqui!!, señores, señoras. ¡Aqui! [...] El presente es la gran oportunidad, sí, este presente de crisis, este presente que algunos llaman incluso, metafóricamente, agrietado, este presente, sí, es la oportunidad para la gran renovación de las estructuras para el progreso, el progreso tenaz de... (BERMAN, 2004, p. 320).

O discurso empolado e prolixo (claramente uma paródia de discursos políticos) do Licenciado F coloca luz nas oportunidades de progresso oferecidas por uma suposta crise, da qual nada sabemos pela peça. A interrupção da fala no início do discurso demonstra que está perdido, por isso chega a construir a tautológica afirmação de que "o presente está aqui”. A maior possibilidade é de "renovação das estruturas de progresso". Instaura-se, portanto, uma tensão temporal em que o futuro planejado anteriormente deve passar por uma revisão.

Como dissemos, em nenhum momento da peça se esclarece qual é a crise, por que ela acontece, se está concentrada na política ou na economia. ${ }^{117}$ Porém, depois que a abertura no teto é percebida pelo casal, gradualmente vão se desvelando as artimanhas dos burocratas e políticos. Nesse sentido, a fissura é o signo teatral da própria crise. Tratase de uma fissura no tempo, como sugerem as palavras de F. Contudo, em que tempo?

Acreditamos que não seja o de um evento histórico específico, mas do tempo da modernidade e da forma que ela tomou no México. Compreendida como uma sucessão linear que sempre conduz a um aprimoramento por meio do desenvolvimento técnico, essa concepção temporal aliada ao progresso fincou raízes em toda a América Latina. Paradoxalmente, na medida em que o estágio de modernização a ser alcançado não chega,

\footnotetext{
${ }^{117}$ A recuperação do contexto de publicação nos informa que se trata da grave crise econômica iniciada em 1982, a qual inicia um período chamado "década perdida". No que tange às questões da produção teatral, os dramaturgos desse período (entre eles Sabina Berman) tiveram que se adaptar às condições de escassos investimentos, muito diferentes do que ocorrera nas três décadas anteriores, quando vários incentivos e ações governamentais fomentaram a produção teatral. Fernando de Ita (1992) afirma que nessa década aconteceu um fenômeno paradoxal: com a ausência de qualquer ação governamental direta na esfera cultural, os autores, principalmente os docentes das cátedras de teatro nas universidades, tiveram que produzir um teatro "independente", "autônomo", ou seja, fora dos meios acadêmicos oficiais. A saída dos diretores "permitió otras formas de producción teatral y le dio acceso al presupuesto universitario a otros necesitados, pero es un hecho que al finalizar la década que reseñamos [a de 80] el teatro universitario en su conjunto era más pobre, en todos los sentidos de la palabra, que diez años atrás." (p.115)
} 
no México a concretização dos ideais revolucionários anunciada pelos discursos oficiais parece sempre estar em vias de se realizar.

Ao longo da história, a não consolidação foi atribuída ao atraso e à incapacidade dos povos latino-americanos, bem como à herança colonial. Tomando como modelo os processos ocorridos em alguns países europeus e nos Estados Unidos, desconsideravam-se as peculiaridades das nações circunscritas ao sul do rio Bravo. Além disso, não se cogitava a possibilidade de que o "progresso" daqueles países era apenas uma forma de se construir maneiras de viver. Nas últimas décadas do século XX, sobretudo a partir da intensificação dos processos de globalização, de abertura para os capitais internacionais, de trocas comerciais em nível planetário e acordos bi e multinacionais, a pasteurização do modelo de desenvolvimento ganha força. No México, esses processos se intensificam a partir do governo de José López Portillo, eleito em 1976 pelo PRI e que governou até 1982, quando foi sucedido por Miguel de la Madrid Hurtado. Essa excursão pelos problemas histórico-econômicos reforça nossa percepção de que a fala do Licenciado $\mathrm{F}$ traz em seu bojo a tensão gerada pela derrocada dos projetos modernizadores no México. A problemática pode ser mais bem compreendida ao recuperarmos os elementos da peça que representam, numa alegoria paródica, a modernização.

O primeiro deles é, sem dúvida, a televisão. Intertexto explícito com 1984 de George Orwell, esse é um dos símbolos mais característicos da cultura da modernidade e que, na cultura mexicana, goza de prestígio, seja por sua competência técnica, seja pela capacidade de fixar concepções bastante criticadas pela classe intelectual. ${ }^{118} \mathrm{Na}$ peça, anuncia-se o progresso moderno assim que a TV é ligada pela primeira vez. "Nos estamos modernizando" - expressam, sedutores, os lábios da tela. Porém, sua chegada parece conduzir a uma imitação alienada. O que se expressa a seguir são ordens visando uniformizar os comportamentos: "que sí, que no, que tal vez: ¡tonteras! Un poco de gimnasia cada día y se acabaron las preguntas: la vida es la vida es la vida es la vida. Guau: ya casi llegamos... ;Caminata, sargentos!”. (BERMAN, 2004, p. 277-278).

O aparelho dita as performances à maneira de "aulas de ginástica". Não sabemos quem ou o que o coloca em funcionamento. Quando se acende, os Funcionários 1 e 2 prontamente executam e repetem os gestos ordenados. ${ }^{119}$ Com esses gestos, a ideia

\footnotetext{
118 A esse respeito ver Televisa, el quinto poder (1985/1989), coordenado por Raúl Trejo Delabre.

${ }^{119}$ Florence Toussaint (“Televisa, una semana de programación. ¿Mente sana en cuerpo sano?”) em Televisa, quinto poder (1989), constata que na década de 80 predominavam na grade das televisões os
} 
de imitação, que Usigli explorou tão profundamente em El gesticulador, é levada a extremos de submissão canina e torna o quadro grotesco. Isso pode ser verificado no uso da expressão "Guau" como transformação da interjeição "wow", típica do inglês, para indicar euforia. A submissão acentua-se não porque as personagens façam uso indiscriminado do inglês, como acontece em outros momentos (por exemplo no "plis, plis" do Empleado 2), mas porque "guau", em espanhol, é onomatopeia de latidos. Essa transformação revela, portanto, não as aulas de ginástica, mas um adestramento cultural e político.

O segundo elemento que marca fortemente a representação paródica da modernidade é o sofá-cama. Junto com a televisão, ele é a mais alta representação do processo de desenvolvimento e, acentua uma ironia mordaz ao progresso técnico. Seu maior benefício está no fato de que sendo um sofá, ele seja também uma... cama! "Un avance técnico impresionante" e "completamente automático", dirá o Empleado 1 ao explicar o funcionamento do móvel. (p. 297).

Porém, o vão entre o encosto e o assento é um depositório de objetos perdidos que serão retirados:

Aquí entre el respaldo y el asiento hay una sección muy traicionera: aquí se pierde cualquier cosa. (Mete entre el respaldo y la saca.) Aquí. Miren: una pluma. (A Él:) Para que no le haga falta. (Vuelve a meter la mano. Va sacando y nombrando:) dos lápices, cuatro plumones, un manojo de 24 lápices de colores, una billetera (esta última no la nombra, sólo se la guarda aprisa en el saco), una corbata (que le da a Él; Él procede a cambiar por su corbata.) iNarváez! ¡Narváez! Este hijo de... se ocupa del inventario; según él en esta oficina roban los encargados de la limpieza, me lleva... (A Él:) ¿Puede abrir esa puerta y gritarle a Narváez mientras yo sigo...?

Sigue sacando objetos: una foto del presidente del sexenio anterior, unos tenis rosas, un sombrerito de charro, una hoz, un martillo, una Virgen de Guadalupe - se persigna ante ella y la tira luego a un lado - una figura azteca de barro... En tanto, en la puerta B, Él está gritando: ¡Narváez! ¡Narváez! El empleado 1 empieza a forcejear por sacar algo; utiliza ambas manos, jala, jala... Por fin saca a Narváez de adentro del sofá. (p. 298).

Os materiais encontrados no vazio do móvel são aspectos da cultura e da história mexicanas. A Virgem de Guadalupe e a imagem asteca de barro dispensam explicações... Já a foz e o martelo remetem às discussões que a partir dos anos 60 colocaram na ordem do dia a instauração do comunismo, pois, embora o desenvolvimento

programas de humor, mais, inclusive, do que as famosas e melodramáticas telenovelas, na proporção de quatro por um. Segundo o estudo, entre os alvos principais do riso estavam os burocratas. 
da capital desde as décadas posteriores à da Revolução indicasse tendências capitalistas, a intelectualidade e os políticos mantiveram grandes debates sobre o assunto, cujo auge aconteceu quando José López Portillo anunciou a nacionalização dos bancos em 82. ${ }^{120}$

O último "objeto", Narváez, o Funcionário 2, merece ser interpretado com mais cuidado. Do ponto de vista histórico, seu nome remete a Pánfilo de Narváez, conquistador enviado de Cuba por Diego de Velázquez para interromper o avanço do poder de Hernán Cortés durante a Conquista. Na crônica de Bernal Díaz del Castillo, Narváez é visto como traidor, opinião que será retomada pelo Licenciado em determinado ponto. Na peça, a descrição física dessa personagem e de seu irmão assemelha-se à de dois presidentes mexicanos, José López Portillo e Carlos Salinas de Gortari: calvos, de bigode e com um leve sobrepeso. Relevante lembrar que, dentre os objetos retirados, está uma "fotografia do presidente do sexênio anterior". Podemos, então, interpretar esses dois “objetos”, Narváez e a fotografia, como signos que indicam a permanência de certas estruturas políticas. Em termos teatrais, a representação dos irmãos por um só ator é o recurso que gera esse efeito de continuidade.

$\mathrm{O}$ efeito de permanência e continuidade da história encontra respaldo na sucessão política. Ao ser eleito, o Presidente Lopez Portillo criou a Secretaria de Programação e Orçamento, que seria ocupada por Miguel de la Madrid Hurtado, de 1978 a 1981. Este último seria o vencedor do pleito presidencial de 1982. O mandato seguinte seria de Carlos Salinas de Gortari. Todos três do PRI. Portanto, os “objetos" encontrados no sofá não estão apenas perdidos, mas também escondidos, "tapados", no jargão jornalístico usado no contexto ${ }^{121}$.

Finalmente, além da TV e do sofá-cama, o último elemento marcante da modernidade, desta vez mais referencial, surge quando a fissura se alargou tanto que já é possível ver através dela. Para enxergar o que está além da estrutura de concreto, uma movimentação e uma gestualidade inusitadas se fazem necessárias. Fabiana sobe nos ombros de seu esposo e coloca a cabeça através da brecha. Vê sinais de modernização: cabos de energia elétrica, antenas (provavelmente de TV), caixas d'água, fumaça e o

\footnotetext{
${ }^{120}$ A respeito das discussões que se seguiram depois do discurso do presidente, ver "La controversia ideológica en torno al VI Informe de José López Portillo. Ensayo de análisis argumentativo", de Gilberto Giménez Montiel (1983).

${ }^{121}$ O sistema de "tapadismo" é um fenômeno em que o presidente em exercício "esconde" o candidato que irá indicar para concorrer à sucessão presidencial. O objetivo é protegê-lo de notícias negativas antes do pleito. Daniel Cosío Villegas descreve o modus operandi do processo em El sistema político mexicano (1974).
} 
grande ponto de referência do DF, a torre da companhia de seguros Latinoamericana. ${ }^{122}$ Percebemos, então, que o escritório está encravado no centro da capital mexicana, com todos os símbolos da modernização construídos entre as décadas de 1940 e 1970.

O prédio ocupado pela seguradora representa uma das mais fortes expressões da modernidade. Se resgatamos a história do local onde se levanta a construção, veremos muitas "camadas temporais" sobrepostas. O arranha-céu ocupa o mesmo espaço que fora a "casa de animais" (o zoológico) de Moctezuma II. Depois da Conquista, foi construído no terreno o Convento de São Francisco. Entre outros fatores que justificam sua apreciação enquanto símbolo de modernidade está a força de sua estrutura, que foi capaz de suportar os muitos terremotos que tem assolado o México desde sempre.

No abalo sísmico de 1985, embora o prédio da Latinoamericana tenha permanecido intacto, não foi o que aconteceu na maior parte da Cidade. O tremor de grau 8.1 na escala Richter deixou vários mortos e destruiu várias edificações. Esse acontecimento que, a rigor, não é histórico (no sentido de que não tem a interferência dos homens no processo de mudança social), está presente também em La grieta. Porém, as estratégias de representação ficcional não coadunam com a expressão documental dos fatos, no sentido de contabilizar os materiais destruídos, os prejuízos econômicos e a grande quantidade de vítimas. ${ }^{123} \mathrm{O}$ terremoto é metaforizado no desabamento do teto do edifício ao final da trama. Ele é o epicentro de um fenômeno crítico: a corrupção, o descaso com a coisa pública, a mentira, o embuste.

Nessa linha alegórica, o terremoto, enquanto fenômeno natural, contrasta com os projetos de progresso e de controle da natureza exaltados pelos processos de modernização. "Tudo que é sólido desmancha no ar", diria Marshall Berman apropriando-se da frase de Marx. Essa dicotomia entre a crença na modernidade e seu fracasso frente a um acontecimento natural foi mencionado por Zygmunt Bauman em Medo líquido (2008). No segundo capítulo, o filósofo analisa as relações entre o medo e o mal. Podemos traçar uma analogia com a peça de Sabina Berman a partir das reflexões que ele faz sobre o terremoto que atingiu a capital portuguesa no século XVIII, em pleno

\footnotetext{
${ }^{122}$ No teatro de Sabina Berman, a Cidade do México aparece com frequência, sobretudo alguns pontos significativos geradores de tensões políticas e recuperadores de momentos históricos. A respeito, veja-se o estudo de V. Daniel Rogers sobre a estátua da Diana Caçadora na peça Entre Villa y una mujer desnuda, na compilação de Jacqueline Bixler (2004).

${ }^{123}$ Para se ter dimensão da transformação promovida nas formas de representação dramática, ressaltamos que, mesmo a TV, que no teatro documental procura promover o efeito de distanciamento, não tem essa função.
} 
contexto iluminista. Bauman mostra que a partir "da sucessão de terremoto, incêndio e maremoto que destruiu Lisboa em 1755 [...] os filósofos modernos separaram os desastres naturais dos males morais - e a diferença tornou-se precisamente a aleatoriedade daqueles (agora reclassificados como cegueira) e a intencionalidade ou premeditação destes.” (p. 79 - itálicos do autor). Depois dessa reflexão, segue a citação de uma carta de Rousseau a Voltaire insistindo que os efeitos do terremoto na cidade poderiam ser amenizados se a distribuição das pessoas não fosse tão concentrada e se os edifícios não fossem tão altos.

No México, após o sismo de 1985, criticou-se a demora do governo em prestar socorro às vítimas - algo em torno de 36 horas. Pela analogia proposta, poderíamos dizer que esses fatos, no contexto em que o presidente Miguel de la Madrid Hurtado promovia um discurso modernizador, com vistas a desmantelar os erros da política econômica do antecessor, mostraram o mal moral que há décadas se reproduzia na esfera política.

O tema da mentira, do embuste emerge a partir daqui substancialmente e, conforme observamos no estudo sobre Rodolfo Usigli, ganha status de recurso metateatral. Para compreender melhor a articulação do tema e sua figuração em recurso técnico, trazemos à baila as informações do prefácio da edição que seguimos: "[La mentira:] El desajuste entre la cosa y el nombre, el desajuste entre la necesidad y la acción. Es, pues, un corte de realidad de un mundo mentiroso, mentido, que condena a sus habitantes a la incoherencia". Imediatamente, a mesma voz didascálica afirma que a ação de mentir é parte constituinte dos mexicanos: "Los mexicanos, doctos en mentir, solemos considerar que [la] incoherencia [a que la mentira condena] es a una vez desastrosa y divertida y la llamamos relajo.” (p. 269). Por essas palavras, vemos que a dramaturga, da mesma forma que Usigli em El gesticulador, aproveita o tema para construir uma tragicomédia bastante significativa nos limiares da pós-modernidade.

Para transfigurar o tema em recurso dramático, outra "brecha” é explorada, a do inconsciente do Licenciado F. No segundo ato, um jogo de mostrar e esconder, típico do teatro, acontece no momento em que surge o Invidente, o contador cego do Licenciado. Anteriormente, o chefe do escritório e Ella estavam sozinhos conversando sobre o emprego que ele lhe oferecia e a seu marido. No diálogo, o burocrata explica que tudo o que ela (ao Licenciado não interessa a presença do cônjuge) deve fazer é "nada", ou melhor, deve esperar o cheque no fim do mês. Fabiana se sente reticente porque sua vontade é de fazer "algo más" (p. 311). Segue-se, então, uma pergunta do político sobre o que mais a incomoda no escritório. Sua resposta é que a fissura no teto é seu maior 
incômodo. O tema irrita o chefe e ele sai de cena, "enérgico y preocupado". (p. 312). O cenário, na sequência, escurece. Quando as luzes voltam, entram o Invidente e depois o Licenciado.

Tratado pelo chefe do escritório por Doutor, o Invidente é, como dissemos, idêntico ao Funcionário 2. Diferencia-se apenas na caracterização por usar óculos escuros e uma bengala. Além disso, carrega um portfólio onde estão guardados documentos sobre o Licenciado, uma espécie de dossiê sobre sua vida financeira e a construção do escritório. As primeiras falas têm um tom enigmático. Paródia das personagens cegas do teatro clássico tais como Tirésias, imitam também ditados populares e frases feitas da língua espanhola: "No por mucho madrugar se amanece más temprano”; "Al que madruga Dios le ayuda”; e uma de contexto indígena: “cuando el tecolote canta, el indio muere.” Não só pelas frases enigmáticas (que oscilam entre o vaticínio e o provérbio popular), mas todo o diálogo inicial entre eles é desencontrado. O Licenciado demora a compreender o Invidente, que passa a falar diretamente. Neste momento, o tom é de denúncia. Os leitores / espectadores, então, têm a dimensão da hipocrisia do dirigente daquele microcosmo.

O Invidente, lendo com os dedos alguns documentos, pronuncia em voz alta os bens do Licenciado: uma casa que vale dez vezes o salário anual, outra em Veracruz que vale cinco anos de trabalho, uma conta bancária no exterior equivalente a 20 anos de salário, investimentos em marcos e ienes em Houston, um "condo" em Miami. A seguir, fala dos desvios e enganos cometidos na construção do escritório: vigas faturadas, mas não colocadas.

Antes que o Invidente continue mostrando mais documentos que delatam a corrupção, F é tomado por um ataque de cólera. Em tom de ameaça, lembra que tanto o contador quanto seu irmão, o Funcionário Narváez, lhe devem gratidão porque lhes deu proteção e lhes ensinou a se vestir, a comer e "a ser gente":

Luego de lo que he hecho por usted y su hermano. Los recogí del fango. Les di trabajo. Les enseñé a vestirse, a comer, a ser gente. Los protegí y los elevé. Y ahora, qué solidaridad. Ya no pido agradecimiento, únicamente compañerismo. Pero no: se confabulan en mí contra. ( $\mathrm{p}$. 315).

A resposta do Invidente é sempre a mesma: “tú fuiste”. O Licenciado F tenta se esquivar das acusações usando subterfúgios argumentativos tais como defender sua 
ação dentro de um cenário de modernização globalizada: "existimos en un contexto internacional, hoy dia nada sucede aisladamente." (p. 314). ${ }^{124}$

Sua última fala demonstra os efeitos da manifestação do inconsciente. Ele está convicto de que, apesar da culpa, não pode lhe acontecer nada:

Yo soy impermeable, doctor. Dígaselo a Narváez, su hermano, ahora que lo vea. $Y$ digale que por eso es imposible que me manchen. $Y$ que por eso también, si les fracasó el plan de tumbarme, de todos modos pueden dormir tranquilos. Porque le digo, soy impermeable: todo se me olvida. Mire: ya se me olvidó. (p. 315).

A crítica à política continua em uma cena bem pantomímica. Quando o Licenciado está conduzindo o contador até a saída, o Invidente bate nas paredes sem acertar a porta. Tenta sair duas vezes e, a cada batida, ele lhe diz: "tantito a la derecha" e "más a la derecha". E acrescenta: "no me entiende." No contexto político que a peça evoca, colocar-se à direita indica alegoricamente filiar-se a favor da situação partidária.

A cena termina com o Invidente sendo jogado pela janela, por não conseguir ou não querer seguir as orientações. Feito isso, a luz desaparece novamente. A escuridão entre a entrada e o assassinato do Invidente indica que as ações ocorrem como lembrança ou como desejo, no inconsciente do Licenciado. Esse mecanismo permite aos espectadores ter acesso ao que está oculto às demais personagens e desvela toda a crueldade e arrogância daquele que, momentos antes, havia sido posto à prova pela jovem Fabiana. Como sucede após os diálogos comprometedores, na cena seguinte a TV volta a ministrar as aulas de ginástica, fazendo com que a descarga emocional provocada pelo impacto da verdade seja amenizada. Dessa forma, produz-se, do ponto de vista técnico, um interessante ritmo na cena, com um profundo sarcasmo no tratamento temático.

Depois de analisarmos os diversos aspectos de La grieta, vemos a transformação operada por Sabina Berman no tratamento dado à história, se comparada com os dramaturgos analisados anteriormente e inclusive quando comparada com sua própria dramaturgia. A dramaturga vê o fato histórico dentro de um continuum no qual certos padrões comportamentais, principalmente do mundo da política no caso de $L a$ grieta, são reproduzidos, imitados, mantidos. O escritório é metonímia da burocracia e do sistema político mexicano, por isso, a estratégia ficcional de concentrar o tempo da ação funciona como síntese de uma longue durée que metaforiza o tratamento displicente

\footnotetext{
${ }^{124}$ Vizcaíno Guerra (2004) mostra que a principal estratégia discursiva para as privatizações, acordos e
} tratados internacionais dos anos 90 foi justamente dizer que era tudo uma tendência mundial. 
com as falhas e os problemas políticos, sociais e culturais ao longo da história. Sem lançar luz em um momento em especial, ela mergulha em problemas mais profundos de seu país. As cenas sarcásticas, o humor negro, os diálogos desencontrados, a gestualidade antimimética, o uso de recursos técnicos que causam sensação de reprodução e repetição, tudo isso produz um "efeito de estranhamento" diferente do que propunha o teatro épico ou o documental.

Em nossa perspectiva, La grieta é um divisor de águas no conjunto da obra de Sabina Berman e da dramaturgia mexicana, no que se refere à interlocução com a história e a historiografia. Essa transformação pode ficar mais explícita na leitura da obra a seguir.

\subsubsection{Entre Villa y una mujer desnuda}

Este é sem dúvida um dos maiores êxitos de público e uma das obras mais estudadas no universo acadêmico. Trabalho de maturidade, estreou em 1993, no Teatro Helénico, na Cidade do México, sob a direção da própria autora, e permaneceu em cartaz pouco mais de dois anos. ${ }^{125} \mathrm{Em} 1995$, foi adaptada para o cinema com o título de Entre Pancho Villa y una mujer desnuda. Trata-se de uma co-produção de Isabelle Tardan e a própria Sabina Berman, que também fez o roteiro e, novamente, se encarregou da direção.

$\mathrm{Na}$ peça, a trama gira em torno do relacionamento amoroso conturbado entre a empresária Gina e o historiador, professor universitário e escritor Adrián. Os conflitos sentimentais, motivados pela incerteza de estabilidade da relação, acontecem ao mesmo tempo em que ele escreve um romance sobre Pancho Villa, cujo manuscrito é datilografado por ela. Paulatinamente, as tensões ultrapassam os limites da intimidade do casal, pois interagem no universo de Gina os sócios Ismael, de 22 anos, e Andrea, neta do ex-presidente Plutarco Elías Calles, além do próprio personagem histórico do livro de Adrián.

A referência a duas figuras emblemáticas da Revolução é o que engendra o diálogo com a historiografia, apesar da ação situar-se em um tempo contemporâneo. Não apenas a época em que se passa a história, mas também o espaço se distancia muito dos cenários tradicionais onde aconteciam as batalhas daquele período, pois a trama localizase em um apartamento na Colonia Condesa, hoje uma das áreas mais nobres da capital.

\footnotetext{
${ }^{125}$ Nas citações dessa obra, utilizaremos a edição de Puro teatro, que é de 2004.
} 
A distância temporal entre as personagens mencionadas e o tempo-espaço da ação implica a elaboração de estratégias ficcionais que as desloquem do pretérito. Assim é que, enquanto Elías Calles se presentifica em algumas palavras e gestos da neta e na composição do cenário, isto é, apenas em discurso, o Pancho Villa que salta das páginas do livro de Adrián é o mítico personagem "de las películas mexicanas de los anos cincuenta, sesenta y setenta. Perfectamente viril, con una facilidad portentosa para la violencia o el sentimentalismo” (p. 160) - conforme anuncia a didascália inicial.

À medida que o passado, através do livro de Adrián, se manifesta e entra em choque com o presente, o conflito do casal se intensifica e ganha tons de tragicomédia. Elementos exemplares desse gênero estão representados na aparição física de Pancho Villa, nas falas e gestos machistas de Adrián, bem como no momento em que Gina pretende dar um ultimato no amante para que se casem.

O tom cômico provocado pela caricaturização machista das personagens provavelmente tem propiciado à fortuna crítica em torno de Entre Villa y una mujer desnuda colocar ênfase no machismo como o tema central da obra. Porém, dentro da perspectiva que adotamos neste trabalho, a questão preponderante é compreender as peculiaridades do procedimento de tratar, mais do que de um evento, de um conhecimento histórico tão marcante no imaginário de uma comunidade.

De fato, as peças de Sabina Berman carregam sempre o questionamento das representações sociais que permanecem ao longo dos tempos. Há que se ressaltar, por outro lado, que, além da naturalização dos comportamentos de gênero, a crítica à exaltação de mitos nacionais está na linha de frente de suas preocupações. Podemos dizer que essa perspectiva encontra suas bases nas reflexões feministas. Portanto, assumimos o ponto de vista de que as preocupações com a posição social da mulher não é o "temaalvo" abordado pela dramaturga nessa peça. Ele parece, antes, cimentar o caminho, oferecer munições conceituais e preparar a reflexão para outros temas.

Nesse sentido, Stuart Day (1999, p. 13) comenta as primeiras movimentações de Gina,

Ao enfatizar a natureza mecânica e ritualística em que vive a protagonista, Berman sublinha o fato de que o comportamento que parece natural é, na verdade, naturalizado, um produto da sociedade. Essa desestabilização do mito do macho nos faz lembrar que o mito é uma construção histórica e que os sistemas sociais, baseados em mitos, podem ser mudados. ${ }^{126}$

126 "By emphasizing the mechanical and ritualistic nature in which the protagonists live, Berman highlights the fact that what seems like natural behavior is naturalized behavior, a product of society. This 
Ao inserir Gina no universo temporal mais elástico, a citação acima autoriza a inferir que a história surge não enquanto um saber necessário para compreender o presente nem para (re)valorizar uma tradição, mas como algo que pode (e em certos contextos deve) ser reelaborado. Por isso, ousaríamos afirmar que a história, em Sabina Berman, é denegação. Não se trata, obviamente, da recusa do acontecimento e sim da narrativa a seu respeito, isto é, trata-se de vasculhar e tentar mostrar de que modo a história foi (é) construída, com artifícios e interesses daqueles que a contam ou a fazem. Sem negar o fato e as personagens centrais que participaram da história, a palavra e a teatralidade desta peça rejeitam a repetição dos gestos, das interpretações, enfim, a naturalização dos comportamentos sociais e a consequente permanência deles ao longo do tempo. O que vemos, portanto, é uma tensão decorrente do conflito gerado pela repetição dos gestos e pela tentativa de romper a cadeia formada pela reprodução e imitação dos comportamentos não mais na política, como na peça anteriormente analisada, mas no campo intelectual e na subjetividade dos indivíduos sociais.

A estratégia para realizar esses propósitos é provocar o encontro do passado e do presente. Por isso, como não encontramos em Entre Villa... a escolha de episódios grandiosos da vida da personagem histórica evocada no título, nem a existência de recriação de uma atmosfera do contexto em que sucede a ação (tal qual se verificaria nos dramas históricos), para o trabalho crítico-analítico escolhemos verificar, em separado, os elementos representativos de cada um dos tempos. Parece-nos, pois, importante recuperar alguns aspectos do passado e do presente explorados na obra.

Doroteo Arango Arámbula, ou Pancho Villa, como se tornou mais conhecido, era filho de pobres camponeses do Norte do México. Nascido em San Juan del Río, em Durango, ele está no imaginário mexicano pela memória de sua vida de bandido e revolucionário. Ocupando lugar de destaque entre os diversos protagonistas da Revolução, apesar de bastante estudado e biografado, possui mais espaço o mito criado ao redor dele do que o homem. A peça de Sabina Berman explora esse caráter mítico. Isso pode ser entrevisto pela didascália inicial, na qual se propõe que Villa seja aquele personagem gerado pelo cinema entre as décadas de 50 e $70 .{ }^{127}$ A opção por esse tipo de caracterização

destabilization of the macho myth reminds us that myth is an historical construct and that social systems, which are based on myths, can be changed."

${ }^{127}$ As primeiras representações de Villa no cinema remontam à década de 30. Filmes dirigidos por Fernando Fuentes, tais como ;Vámonos con Pancho Villa! (1933), foram os primeiros a cultivar a imagem de um homem viril, capaz de agir com rigor a favor de los de abajo. Na década de 50, época de ouro do cinema 
do personagem se incorpora também a alguns diálogos tais como aquele entre Gina e o namorado quando comentam que o número estimado de mulheres do Chefe da Divisão do Norte chegou a trezentos. Ao que Adrián, em uma resposta serpentina, movendo-se entre o historiador e o machista, responde: “Las cifras se pierden en lo mítico.” (p. 170)

De personalidade forte e espírito belicoso, Pancho Villa tinha também poder de organizar massas de adeptos à causa revolucionária. Percorrer sua história de vida é acompanhar as batalhas e as errâncias da Revolução iniciada em 1910, quando ele tinha 32 anos e uma larga experiência de saques, emboscadas e combates. Além disso, o acompanhamento de sua biografia nos conduz a descobrir as articulações e traições políticas que deram ao movimento um valor que oscila entre o elogio e a condenação. Seja por episódios dignos de uma ficção repleta de ação, como o dia em que foi salvo do fuzilamento, em 1911, pelo tenente coronel Guillermo Rubio Navarrete e a fuga da prisão de Tlatelolco, no ano seguinte, com ajuda de Carlitos Jáuregui, seja pela peculiaridade de algumas vivências (fictícias?), tais como o aprendizado das primeiras letras a partir do Dom Quixote, o certo é que o "Centauro do Norte" ocupa um locus significativo no imaginário mexicano que vai muito além do histórico.

A morte do caudilho ocorreu em vinte de julho de 1923. Foi o último líder revolucionário a ser morto, quando os tempos de efervescência da Revolução já haviam arrefecido. Luz Corral, uma das esposas de Villa, autora de uma biografia, atribui a Plutarco Elías Calles, presidente do país entre 1924 e 1928, a ordem de assassiná-1o. ${ }^{128}$ O primeiro contato entre eles aconteceu em 1913. Calles era líder político sonorense e chefe militar da cidade de Agua Prieta, onde Villa comprava munição. Em outubro de 1914, a cidade, que faz fronteira com os Estados Unidos, estava sob a proteção de Plutarco Elías e Lázaro Cárdenas. Villa, neste ano, já havia perdido as forças (armas, munições, artilharia, homens e outras cidades), mas tentou ocupar Agua Prieta. Calles tinha recebido permissão do presidente estadunidense Woodrow Wilson, que também já reconhecera oficialmente o governo de Venustiano Carranza, na luta contra Villa e suas tropas.

mexicano, apesar da produção em torno do caudilho ter diminuído, persistem os filmes que cultivam o mito criado nas duas décadas anteriores. Nesse momento, o destaque é para a trilogia de Ismael Rodríguez: Así era Pancho Villa, Pancho Villa y la Valentina e Cuando ;Viva Villa! es la muerte. Como veremos mais adiante, nas representações elaboradas por Rodríguez convivem a virilidade e a jocosidade do herói. Nos anos 60, ganha notoriedade El correo del norte, (1960), de Zacarias Gomez Urquiza e Herencia Maldita (1963). Da década de 70 (anos de formação intelectual de Sabina Berman), o título de La muerte de Pancho Villa (1973), produzido por Antonio Aguilar, parece anunciar o fim de um ciclo.

${ }^{128}$ Hoje, o estudo mais completo e mais bem aceito pela comunidade acadêmica é a biografia escrita por Friedrich Katz em 1998. Nela, o historiador austríaco radicado nos Estados Unidos defende que a morte de Villa foi orquestrada por Álvaro Obregón. 
Plutarco Elías Calles, depois de deixar a presidência em 1928, atuou nos bastidores da política: chamado de Jefe Máximo da Revolução, fundou o Partido Nacional Revolucionário (PNR), que depois se tornou o Partido Revolucionário Institucional (PRI), e ajudou a eleger Lázaro Cárdenas, que romperia com o "padrinho" político. O período em que Calles atuou na coxia da política é conhecido como Maximato (1928 - 1934).

Para além desses conhecimentos evocados pela peça, a presença de Pancho Villa na relação de Gina e Adrián coloca-se como um flagrante elemento de oposição à atividade profissional de ambos os protagonistas. Se o caudilho representa a permanência do passado, de sua perspectiva nacionalista, o ramo de atuação escolhido pelas sócias Gina e Andrea evidencia uma forma de organização econômica e social bem diferente da idealizada pelo líder revolucionário e compartilhada por Adrián.

Comparando as duas formas de condução de "negócios", precisamos nos lembrar, por exemplo, que entre os anos de 1913 e 1915, Pancho Villa esteve à frente da administração do estado de Chihuahua. Nesse período, semeou os projetos que tinha em mente e desenvolveu uma gestão que conseguiu elevar o nível de vida dos trabalhadores rurais e urbanos. (VILLA, 1992). As políticas de reconhecimento dos direitos do grupo tarahumara, a preocupação com a educação — incluindo a valorização salarial de professores - , as mudanças do traçado urbano da capital, a conquista de níveis baixíssimos de desemprego, a distribuição de terras expropriadas - as quais os novos proprietários tinham obrigação de tornar produtivas sob pena de perdê-las e outros fatores contribuíram para, ao longo dos anos, transformar Villa no ideal de chefe comunista, embora haja conflitos teóricos em jogo nessa linha de análise, pois, conforme defende Marco Antônio Villa (1992), a mexicana foi a última revolução em que a participação camponesa não se fez impulsionada pelo marxismo ou pelas ideologias socialistas.

Por outro lado, a atividade industrial à qual se dedicam as sócias Gina e Andrea e o jovem Ismael, as maquiladoras, representa um dos mais avançados estágios do processo global de transnacionalização da economia. O termo maquila, de origem árabe, designava em seus primeiros usos (por volta do século XVI) a moedura de grãos. Dizia respeito à quantidade de produto a que tinha direito o moedor em troca de seu serviço. No uso corrente que aparece na peça de Sabina Berman, pode-se definir maquiladora como uma atividade particular do processo industrial de um produto (por exemplo, encaixotamento ou embalagem) que não é realizada pela empresa fabricante 
original. (TAYLOR HANSEN, 2003). ${ }^{129}$ Por outro lado, as maquiladoras também oferecem serviços, sobretudo na área de turismo.

Trata-se de um fenômeno do comércio exterior motivado evidentemente pela acentuação dos processos de globalização. No México ${ }^{130}$, ele chegou a caracterizar-se mais fortemente na região norte do país devido aos programas federais de incentivo à indústria que se expandiram desde a década de 40 e ganharam impulso com o Programa Nacional Fronteiriço, de 1961, e o Programa de Industrialização da Fronteira, de 1965. A indústria de maquiladoras aparece neste último ano com o nome oficial de "indústria em zona franca". (p. 1051).

Dentre os aspectos negativos do processo, Taylor Hansen (p. 1056) destaca que

en lugar de promover vínculos económicos entre la región fronteriza y el interior del país, la cantidad cada vez mayor de maquiladoras en la frontera sirvió para fortalecer los vínculos con el suroeste de Estados Unidos, así como para aumentar la presencia estadounidense en México.

Pela comparação entre as práticas administrativo-econômicas das sócias e da personagem histórica, podemos concluir que Pancho Villa representa o ideal comunista e revolucionário projetado em um presente que já não se organiza da maneira idealizada. A tensão entre Gina e Adrián se constrói a partir dessa dicotomia. No momento em que a empresária decide romper o relacionamento, o escritor se queixa alegando que "así son los neoliberales, ¿no es cierto?, no sirve, a la mierda: ¡iya no!!” (p. 191). Na cena 5 do primeiro ato, ao ter uma "plática ligera" com Gina, Adrián rejeita que falem da maquiladora:

ADRIÁN: No. No me interesa tu trabajo.

GINA: Ah vaya: mi trabajo no te interesa.

ADRIÁN: No. Sinceramente, no. Especialmente no cuando estás montando una maquiladora, es decir cuando te afilias al vendaval neoliberal que está desgraciando a este país. (p. 168).

Essa postura contrária ao trabalho da amante é corroborada com sua postura contra "los dinosaurios priístas, la maldita derecha" e a crítica aos alunos para os quais

\footnotetext{
${ }^{129}$ Essa definição que parafraseamos é citada literalmente por Lawrence Douglas Taylor Hansen, autor do artigo de onde retiramos as importantes considerações sobre as maquiladoras. A citação foi recuperada de Carlos Angulo P. em "Foreign investiment and the maquiladora export industry", em Inversión extranjera directa: Direct Foreign Investment, Banamex, México, 1990, ao qual, infelizmente, não tivemos acesso. ${ }^{130}$ Alguns estudiosos da área afirmam que as maquiladoras são, aliás, um fenômeno impulsionado pelo próprio México.
} 
leciona, "puro pendejete reformista" (p. 167-168). Adrián, portanto, manifesta-se quase sempre como um homem de esquerda, herdeiro do projeto villista, que se opõe às transformações econômicas e sociais pelas quais seu país começa a passar.

A contradição entre essa visão de mundo e a ação neoliberal também se faz presente quando Andrea, no último ato, conta que comprou e leu o romance de Adrián em uma loja da rede Vips. Nesse sentido, manifesta-se a veia sarcástica de Sabina Berman, pois o empresário fundador desse grande conglomerado espanhol de restaurantes e lojas de conveniência nasceu no México, embora fosse filho de pai ibérico.

Essas contradições são observadas também por Stuart Day (1999). Para ele, Adrián representa o discurso da esquerda mexicana. Seu brado pela revolução, ao escrever uma biografia [sic $]^{131}$ de Pancho Villa, é tão vazio de verdade quanto seu desejo de se casar com Gina depois que ela exige mais comunicação entre eles. Enquanto Adrián finge se importar com o legado revolucionário (ou com a falta de concretização daqueles ideais), a esquerda finge mantê-lo vivo na política, mesmo vivendo sob condições distintas daquelas que motivaram as lutas camponesas.

Adrián está marcado pelos signos do liberalismo; é um professor universitário de história que escreve para o La Jornada, um jornal de centro-esquerda da Cidade do México. Sua posição como historiador da Revolução (não um historiador revolucionário) serve para sublinhar o status dos mitos como narrativas subjetivas que permanecem no presente, tal como elas são narradas. (DAY, p. 11). ${ }^{132}$

As contradições entre o passado e o presente e entre a permanência do ideal revolucionário e a realidade neoliberal geram a busca de formas de encenação que possibilitem demonstrar a sobreposição temporal. Sharon Magnarelli (1996) expressa essa mistura temporal em termos de justaposição. Seu artigo "A tea for two: performing history and desire in Sabina Berman's Entre Villa y una mujer desnuda" se constrói sobre o conceito de "citational performances" desenvolvido Judith Butler em Gender troubles and bodies that matter. No entender de Magnarelli, a teórica feminista norte-americana propõe que a subjetividade ou identidade de gênero seja o resultado de "citational and performative acts" que, ao mesmo tempo em que repetem também legitimam os papéis sociais inscritos e autorizados. Dessa forma, ao realizar a crítica da peça de Berman, a

\footnotetext{
131 Adrián não escreve uma biografia, mas um romance.

132 "Adrián is marked by the signs of liberalism; he is a university history professor who writes for $L a$ Jornada, a left-of-center newspaper in Mexico City. His position as a historian of the Revolution (but not a revolutionary historian) serves to highlight the status of myths as subjective narratives existing in the present, as they are narrated."
} 
pesquisadora defende que existe em Entre Villa... uma série de comportamentos repetitivos, semelhantes a citações, herdados das narrativas históricas. Assim ela expressa sua perspectiva sobre os efeitos da história nas atuações de gênero na peça:

Para enfatizar os efeitos da história na identidade de gênero, Berman justapõe [as] cenas da vida contemporânea com cenas protagonizadas por Pancho Villa, uma personagem fictícia e histórica da monografia [sic] que Adrián escreve. Nesse sentido, a dramaturga mexicana realiza uma análise profunda do poder das práticas discursivas e dramatiza como a narrativa (seja em forma de história, cultura popular, ou até mesmo de estórias que nos são contadas pelos outros) autoriza e inscreve os papéis de gênero que citamos e representamos. (MAGNARELLI, 1996, p.56). ${ }^{133}$

Esse aspecto foi sublinhado também por Jacqueline Bixler. No entanto, ela amplia a discussão ao objetar que não é em função das questões de gênero que a história está representada. Como já dissemos, a problemática é justamente inversa. Para Bixler (1997, p. 45):

Mais do que simplesmente ressuscitar aqueles eventos históricos para "a lembrança", Berman pós-moderniza a história para destacar sua representação e para lembrar sua audiência de que os eventos do passado adquirem não sua existência, mas seu significado graças à sua representação, quer eles estejam nas páginas de um texto ou no palco. ${ }^{134}$ (negrito da autora).

Com efeito, por mais que a identificação do recurso de justaposição temporal seja acertada, duvidamos da tese postulada segundo a qual as práticas discursivas presentes na peça legitimam e inscrevem os papéis de gênero representados e "citados". Há que se destacar que a prática discursiva que realmente reproduz as formas de agir do passado no presente é o romance (e não uma "monografia") que Adrián está escrevendo sobre Pancho Villa. Adrián é um historiador profundamente envolvido com seu objeto de estudo, que, apesar de reconhecer os limites entre a produção historiográfica e a criação dos mitos, busca retratar Pancho Villa tal como sua imagem foi construída a partir de um momento da história de seu país. Além disso, na maior parte da peça o vemos preparando

\footnotetext{
133 "To emphasize the effects of history on gender identity, Berman juxtaposes these scenes of contemporary life with scenes protagonized by Pancho Villa, the fictitious-historical character from the monograph Adrián is writing. In this respect, the Mexican playwright provides an insightful analysis of the power of discursive practices and dramatizes how narrative (in the form of history, popular culture, or even the stories told us by others) author(ize)s the gender roles we cite and perform."

${ }^{134}$ Rather than resurrect these historical episodes simply for "the record," Berman postmodernizes history to foreground its representation and to remind her audience that events from the past acquire not their existence, but their meaning thanks to their representation, whether it be on the pages of a text or on the stage."
} 
o livro, ou seja, exercendo uma atividade reflexiva, de preparação, de levantamento de dados. Atitude que o desagrada e que, conforme veremos mais adiante, nos oferece muitas pistas para compreender sua atitude no final da peça.

Como sabemos, a preparação de uma pesquisa, o levantamento de dados, a coleta de documentação que auxilia na construção de uma obra, historiográfica ou ficcional, frequentemente nos coloca em confronto com o senso-comum ou as hipóteses iniciais. De antemão, sabemos que a pesquisa pode nos apresentar algo distinto daquilo que imaginávamos encontrar. Não fica difícil, pois, inferir que Adrián, na etapa prévia que antecede a escrita (ou como ele diz, a cavalgadura junto com o Centauro do Norte rumo à Cidade do México), tem suas concepções prévias confrontadas. Conforme já notamos, em determinado momento, quando questionado por Gina sobre o número de mulheres que Pancho Villa teve, afirma que "las cifras se pierden en lo mítico." (BERMAN, p.170). A compreensão de que o mito entra em conflito com os números ou de que os números são tão abstratos que só permitem instigar a imaginação — poderia ser tomada como um indício de que Adrián não encontra lugar em seu papel de macho e de historiador e de que ele busca apenas legitimar um passado que atende a uma ideologia herdeira da Revolução. Nesse sentido, a presença do fantasma ${ }^{135}$ de Villa assola, mas é frequentemente negado.

Com efeito, outro aspecto que precisa ser ponderado na tese de Sharon Magnarelli (1996) é a interferência do passado no presente. Defendemos justamente o contrário: o presente recupera o pretérito e frequentemente procura negá-lo. A cena que melhor comprova essa assertiva acontece quando Gina está datilografando os manuscritos de Adrián. Em um processo altamente metateatral, as personagens Pancho Villa e Micaela Arango, sua mãe, representam aquilo que Gina transpõe do manuscrito para a máquina de escrever. Mais do que a justaposição temporal, o que vemos é um imbricamento dos tempos, do qual resulta o conflito de toda a peça. Quando "Gina enciende un cigarro: Villa se alarma." (p. 174). A seguir, "Gina exhala un chorrito de humo" sobre ele, que confunde a fumaça do cigarro com a dos campos de batalha e o ruído das teclas com os tiros.

Essa invasão do presente no pretérito evocado pela narrativa de Adrián que Gina passa a limpo continua a ponto de a "escriturária" desculpar-se por inserir, na fala

\footnotetext{
${ }^{135}$ Inserimos o termo fantasma seguindo o sentido que lhe empresta Jacques Derrida (2002) em famosa entrevista sobre o papel do cinema no imaginário. Mais adiante, estaremos em condição de explorar melhor essa ideia em Entre Villa y una mujer desnuda.
} 
de Dona Micaela, palavras que a mãe do revolucionário talvez não dissesse ao filho, mas que fortemente marcam o desejo de Gina de se libertar, via discurso, do machismo impregnado na cultura ao longo da história:

DOÑA MICAELA: Pero es que la vida que llevas, siempre a salto de mata. ¿Quién le zurce los calcetines? ¿Quién se fija que su sarape esté limpio? Y si te duele una muela, ¿a quién le cuentas?

VILLA: Pos' ai tengo unas cuantas señoras que me quieren...

DOÑA MICAELA: Pero ni una casada contigo por la Iglesia y ante Dios.

VILLA: Cómo no. Cinco casadas conmigo por la Iglesia y ante Dios. DOÑA MICAELA: ¡Jesús santo! (Se persigna.) ¡Nombres!

VILLA: ¿Cómo dijo, madrecita?

DOÑA MICAELA: Quiero nombres, direcciones y apelativos de esas fulanas y de todas tus queridas. Las de ahora y las dendenantes.

VILLA: ¿Qué dice, madrecita?

GINA: Ay, perdón. Perdón, perdón, perdón. (p. 175).

No trecho acima fica evidente a interferência de Gina no diálogo (portanto, na história) das personagens do livro. A última fala de Doña Micaela apresenta um tom completamente distinto das anteriores. Em nossa leitura, essa postura de Gina evidencia a dificuldade que ela tem de aceitar os comportamentos herdados da história. Pancho Villa, enquanto personagem que teve uma imagem fixada no tempo se desestabiliza, por isso a mãe, assumindo, pelas palavras, a postura discursiva de Gina, indaga o filho sobre o nome das "fulanas".

A sobreposição temporal verificada no trecho acima nos induz ainda a refletir sobre a metateatralidade da peça. Na cena citada, a presença de Pancho Villa e de sua mãe oscilam entre a projeção da consciência de Gina e o caráter absurdo do convívio dos acontecimentos no mesmo ambiente. A projeção origina-se da escrita, mas a simultaneidade entre o evento e ela é de ordem especial. Trata-se de uma etapa de "passar a limpo", ou seja, de organizar apontamentos e mobilizar estratégias para estruturar definitivamente o texto. Com efeito, identificamos que a metateatralidade nesse momento se caracteriza pela consciência que Gina tem do passado, e de sua possibilidade de intervir nele por meio da escrita.

Outro momento significativo em que a estruturação metateatral serve para demonstrar a intervenção do presente no passado sucede na cena em que a empresária está terminando o relacionamento com Adrián. Ele havia desaparecido durante cento e vinte dias. No último encontro, prometera que aceitaria ter um filho com a companheira. Ao voltar depois da longa ausência, ela, espécie de Penélope contemporânea, reivindica 
explicações do amante, mas não obtém nenhuma que lhe seja satisfatória. Ele argumenta que usou o período para terminar e publicar o romance que vinha escrevendo e que estava com muito trabalho na universidade e no jornal. Diante do aborrecimento da empresária e de sua manifestação de romper o relacionamento, o escritor tenta forçar a continuidade da relação. Busca, inclusive, o sexo. Após uma discussão, Adrián está prestes a sair e, na porta, se encontra com Pancho Villa. A partir disso, em toda a cena veremos o caudilho morrer paulatina e simbolicamente:

$\mathrm{Al}$ abrir de golpe la puerta, Adrián se encuentra a don Pancho Villa.

VILlA: Despacio, compañerito Pineda. Con calma. Con ternura. ¿Pa'que las quiere si no es para la ternura? (Acompañándolo hacia Gina:) Ándele. ADRIÁN: Gina... Este...

GINA: Ya no, Adrián, por piedad.

ADRIÁN: Gina, es que...

VILLA: Carajo: $y a$.

ADRIÁN: Siento haber desaparecido tres meses, pero... Todo se puede arreglar.

GINA: No.

ADRIÁN: Todo.

GINA: ;NO!

VILLA: Aunque no parezca, está cediendo. Nomás toques las cuerdas más poquito a poco y pronto canta... (p. 192).

Gina se mantém intransigível em sua postura de terminar o relacionamento, inclusive porque já está envolvida com Ismael, o jovem design dos produtos da maquiladora. Adrián, por seu turno, sempre faz concessões e não consegue persuadir Gina a mudar a decisão. A cada nova concessão do escritor, Pancho Villa é ferido:

GINA: Ahora por fin tengo confianza en un hombre, pero por desgracia no eres tú.

VILLA: Qué agonía más lenta, hijos de su madre...

GINA: No, Adrián: no llores Adrián.

Otro balazo sobre Villa. (p. 197-198)

A postura de Gina demonstra a conquista de uma força que até então era atribuída a Adrián, ou seja, suas habilidades de oratória, o uso da palavra como poder hipnótico; esses recursos já não são suficientes para fazê-la ceder aos encantos do intelectual. O auge dessa força acontece no final da cena, quando o próprio Pancho Villa passa a mimetizar a fala de Gina como tentativa de convencer Adrián de que ele não pode aceitar o que a mulher está fazendo: 
GINA: Por eso: ya vete, Adrián.

VILLA: Por eso, ya mátela, con sus propias manos.

ADRIÁN: Está bien, voy a divorciarme, de todos modos era sólo un trámite que no hacía por desidial

GINA: No quiero.

ADRIÁN: Aquel día venía a proponertel

GINA: Adrián, por favor, ya vete.

VILLA: Adrián, por favor: ya mátala...

Adrián observa el lugar con extrañeza. Se aparta de Gina y Villa y se pasea nerviosamente, ensimismado.

GINA: Adrián.

VILLA: Adrián.

Pausa.

GINA: Adrián. ¿Qué esperas, Adrián?

VILLA: ¿Qué esperas, Adrián?

Pausa.

GINA: ¿Podrías ya irte? ¿Adrián?

VILLA: ¿Podrías ya torcerle el cogote, Adrián? (p. 199-200).

A reprodução da fala de Gina por Villa (procedimento inverso ao de quando ela datilografava o livro) simboliza a transformação da cultura machista, porque absorve o discurso do Outro, mesmo que seja apenas a forma e não o conteúdo. Aliada ao mimetismo da movimentação cênica, a interferência do presente no passado provoca a sensação de que o pretérito, representado por Villa, está se esvaindo e o sentido que ele carrega está sendo substituído. Esse jogo de substituição de identidades conota uma estratégia metateatral, porque mostra a formação das identidades e das máscaras.

A cena termina com a cômica e fracassada tentativa de suicídio de Adrián, porquanto o apartamento de Gina é no térreo. Dessa forma termina também o relacionamento dos dois.

Por outro lado, o fim da conflituosa relação não encerra a peça. Nas últimas cenas, emerge a problemática do como se escreve a história. Nesse ponto, reaparece a temática do uso de ardis no processo de elaboração da historiografia. Esse tópico, que apareceu também em peças já analisadas nesta tese, ganha corpo com as novas formações amorosas surgidas em decorrência do rompimento da empresária com o historiador. Nas últimas cenas, Gina se envolve amorosamente com seu sócio Ismael. Adrián, por sua vez, tem um flerte com Andrea. 
Esse novo ordenamento das individualidades oferece novas configurações sociais, as quais devem ser compreendidas à luz de aspectos que dizem respeito tanto aos procedimentos ficcionais quanto às implicações temáticas.

O primeiro aspecto refere-se à reelaboração histórica a partir dos documentos. Enquanto estratégia de ficcionalização, observa-se a atualização do discurso de Pancho Villa no diálogo com sua mãe, Dorotea Arango. Nessa conversa, por si só uma inconsistência histórica (porque, enquanto os registros históricos demonstram que sua mãe faleceu antes de que ele aderisse à causa, o Villa que aparece em cena é o revolucionário), Sabina Berman se apropria do registro feito por uma das viúvas do caudilho, Corral de Villa. Dentre as histórias contadas pela esposa, uma narra a atitude do marido à véspera do casamento:

Entramos a la iglesia, donde algunas personas estaban terminando de adornar el altar. Yo recuerdo con amor esos detalles; gozosos los dos estuvimos contemplando los últimos toques del arreglo, cuando el Cura Muñoz, celoso del cumplimiento de sus deberes, se acercó a Pancho y le interrogó: 'Coronel ¿se va Ud. a confesar?' Pancho le miró por un momento y luego le dijo: 'Mire, para confesarme, necesita Ud. no menos de ocho días, y como Ud. ve, está todo arreglado para que la boda sea mañana. Además, necesitaría tener un corazón más grande que el mío, para decirle todo lo que el Señor me ha dado licencia de hacer; pero si gusta, póngale a montón que iguale, absuélvame y arreglados...' (Corral de Villa apud CUITLÁHUAC CHÁVEZ, 2013, p. 89).

Na cena 6 do Ato I, a mãe do revolucionário pede que ele se confesse antes de ir à guerra, ao que o filho responde:

Mire, mamacita, Doña Micaela, para confesarme necesitaría al menos ocho días y usté bien oye que ahí fuera está la guerra esperándome. Además, necesitaría usté conseguirme un cura con el corazón muy grande, más grande que el mío, para que yo le dijera todo lo que el Señor me ha dado licencia de hacer. (BERMAN, 2004, p. 176-177).

Impossível deixar mais explícita a apropriação das memórias da viúva pela dramaturga. Do ponto de vista do efeito causado pela apropriação, destacamos que, pelo relato da esposa, vemos um Villa autossuficiente, quase antirreligioso, tão seguro de sua bondade e de seus sentimentos que não acredita no sacramento da confissão. No plano ficcional, a questão é suavemente deslocada. A guerra passa a ser o motivo para não realizar o ato de confissão. O Villa registrado pela viúva, apesar de se considerar autorizado por Deus para cometer atos contrários aos preceitos cristãos, atende às normas 
religiosas. Já o Villa ficcionalizado mantém a violência como característica principal de sua personalidade: não pode se confessar porque a guerra o espera.

É necessário recordar que essa fala de Villa reproduz as palavras do livro de Adrián que Gina está datilografando. Nessa representação de representação, arriscamos exprimir que, enquanto o romance ficcional incorporado à história do casal enfatiza o caráter revolucionário e beligerante do protagonista, a peça o caricaturiza. Os resultados são, respectivamente, permanência e desconstrução do mito.

A fim de compreender melhor as implicações e os efeitos de sentido provocados por esse espelhamento de representações, pode ser útil uma analogia com a Corona de luz, de Usigli. Na recuperação do mito da Virgem de Guadalupe, embora fique evidente a preocupação com a documentação historiográfica, o caráter lendário das personagens não é destruído, antes, são enfatizados os aspectos mítico e sacro que envolvem a santa revelada para o índio Juan Diego. Por outro lado, na peça de Berman, o uso das confissões da viúva busca desvelar o mito oferecendo outra perspectiva histórica. A desmitificação alcançada pela caricaturização sobrepassa o indivíduo e atinge toda a "aura" em torno do macho mexicano que se evoca a partir da figura de Doroteo Arango.

Ainda no esteio das analogias, é imprescindível destacar que a forma de propor essa desconstrução não segue uma tradição mais recorrente, representada por Leñero, de colocar em confronto com a ficção os documentos sobre o fato histórico, pois o questionamento do mito em Entre Villa... é feito pelo confronto com uma obra ficcional. Com efeito, critica-se, então, a simbologia de Pancho Villa. Assentado e aceito culturalmente, ele representa o imaginário de uma forma de agir dos homens mexicanos. Dessa forma, ele não é a personagem histórica que impulsionou a Revolução iniciada em 1910, mas a continuidade, a propagação e a permanência do estereótipo do macho. A tensão entrevista na peça decorre do fato de que ele é tomado como algo existente, mas que está passando por transformações. Por isso, a documentação não é explorada com vistas a apresentar novos conhecimentos capazes de comprovar o caráter "errôneo" da lenda de Pancho Villa (como propôs, por exemplo Friedrich Katz sob uma perspectiva historiográfica), mas sim mostrar a emancipação cultural do mito via personagem de Gina.

As opiniões expostas anteriormente são possíveis porque o Villa de Berman não é o da história, mas sim o do cinema dos anos 50, 60 e 70. Dessa articulação com o cinema decorrem os maiores desafios para interpretar os procedimentos de intersecção entre dramaturgia e história, porque o modelo machista denunciado pela autora é formulado pela sétima arte. Berman não quer retratar uma personagem "real", mas uma 
representação. Seu Villa, portanto, é representação de representação. Embora a autora demonstre ter conhecimento dos documentos acerca de Villa e da revolução (por exemplo, ao usar as memórias de Corral, espécie de documento de uma historicidade posterior àquela referenciada pela personagem histórico Pancho Villa), não é a eles que ela recorre, mas sim ao imaginário forjado pelo cinema. Com efeito, é possível afirmar que esse caráter, digamos, "metarrepresentacional" é o que confere originalidade à criação ficcional a partir de dados históricos.

Para compreendermos mais claramente a proposta da dramaturga, podemos recorrer ao conceito de fantasma de Derrida (2002). Em entrevista aos Cahiers du cinéma, o filósofo relaciona a sétima arte com o conceito de espectralidade, oriundo da psicanálise freudiana. Assim como Freud denominava o espectro como unheimilich, ou seja, estranhamente familiar, Derrida afirma que as imagens cinematográficas são capazes de produzir "enxertos de espectralidade" ou "memórias espectrais". Para o filósofo, isso significa que a projeção da imagem na tela cria, no espectador, uma memória ao mesmo tempo em que ativa as lembranças dos filmes já vistos. A retroalimentação da memória por meio das projeções cria um duelo entre os fantasmas - tanto os lembrados quando os que são forjados no instante em que assistimos à projeção de um filme. Nas palavras do próprio filósofo,

\begin{abstract}
Memoria espectral, el cine es un duelo magnífico, un trabajo de duelo magnificado. $Y$ se presta a dejarse impresionar por todas las memorias en duelo, es decir, por los momentos trágicos o épicos de la historia. Son entonces esos duelos sucesivos, ligados a la historia y al cine, los que hoy "hacen marchar" a los más interesantes personajes. (DERRIDA, 2002, p. 98).
\end{abstract}

As palavras finais da entrevista auxiliam-nos a compreender o efeito de sentido conquistado pela personagem de Pancho Villa. Ele é o espectro da masculinidade, da virilidade, do macho mexicano, herdado dos filmes das décadas de 50, 60 e 70. Para ilustrar essa relação entre a memória espectral de Villa com a peça, escolhemos o filme Así era Pancho Villa (1958) ${ }^{136}$, do diretor, produtor e roteirista Ismael Rodríguez (19172004), seguramente um dos cineastas que mais contribuíram para gerar a imagem de um Villa que oscila entre justiceiro, viril e jocoso.

\footnotetext{
${ }^{136}$ Tivemos oportunidade de assistir ao filme quando ainda estava disponível completamente no Youtube.
} 
Cuitláhuac Chávez (2013) elenca de maneira exemplar as transformações pelas quais passou a imagem do caudilho. Para o autor, em Así era Pancho Villa ${ }^{137}$ "podemos apreciar a un Villa orgulloso, seguro de sí mismo, ingenioso, pero sobre todo, es hipermasculino, mujeriego y devoto. Éste era el modelo de hombría que debía inculcarse al público masculino" e que foi impulsionado por esse e outras obras de Ismael Rodríguez.

$\mathrm{Na}$ abertura do filme, é mostrado em plano aberto um mausoléu erguido para o caudilho. A seguir, colocada paulatinamente em detalhes, a câmera mostra uma pequena lápide inserida num humilde cemitério de Parral. Essas imagens são explicadas pela voz em off de Pancho Villa. A seguir, a câmera nos leva a um ambiente fechado e escuro, com diversos móveis sobrepostos, em uma atmosfera de desorganização, totalmente contrária à grandiosidade representada pelo mausoléu. No meio dos escombros — ainda ouvindo a voz de Pancho Villa, somos informados de que estamos em um Instituto, "lugar donde cada uno piensa lo que quiere" —, está a cabeça do caudilho, a qual nos é exposta antes de começar os relatos que compõem a narrativa. Essa atmosfera gótica da abertura tem o objetivo de contrapor história, o estudo meticuloso e científico, às lembranças. Em um espaço aberto e público, o cemitério, Villa apresenta-se, como parte do mausoléu, grandioso, mas no ambiente fechado do Instituto, restrito, é apenas mais uma peça entre muitos fragmentos de história.

O filme está construído com cinco narrativas evocadas pelas lembranças do caudilho. Não é nosso interesse expor todas elas nem fazer uma análise completa. Para nossos propósitos, algumas cenas serão singularmente ilustrativas. Na primeira narrativa, "No matarás", Villa manda fuzilar vários oficiais do exército federalista e políticos da região onde está - provavelmente no Norte, embora não nos seja indicada a cidade nem o estado. Depois do fuzilamento, Villa é repreendido por Francisco I. Madero, pois estaria colocando em perigo os ideais da Revolução todas as vezes que optava por matar cidadãos como aqueles. No diálogo, a resposta de Villa oferece o tom da personagem ao longo do filme: um homem firme de ideias e ações; movido pelos sentimentos. Ao mesmo tempo, olhado com a distância que temos hoje, vislumbramos uma imagem jocosa do líder, decorrente do fato de ele ser um seguidor restrito, de entendimento literal das ordens e

\footnotetext{
${ }^{137}$ Além desse filme, Cuitláuac Chávez analisa Pancho Villa y la Valentina, do mesmo diretor e produzido no mesmo ano. A fórmula utilizada é a mesma nessas e em outras produções, o que permitiu o sucesso de público em sua época.
} 
incapaz de perceber sutilezas discursivas. Isso acontece já em um dos primeiros diálogos entre Villa e Madero:

VILLA: Pero fue Usted quien dijo que era necesario cortar el mal por la raíz, general.

MADERO: Pero no fusilando a los oficiales.

Na cena, infere-se que "cortar o mal pela raíz" propunha uma conotação metafórica. Villa, pelo contrário, entende que o mal está nos opositores da Revolução e por isso mereceriam ser assassinados. A seguir, em close-up, primeiro, é mostrado o rosto desolado de Madero, triste por ver que seu interlocutor, e um dos principais homens de ação a favor da causa revolucionária, não entende a força da expressão "cortar o mal pela raiz"; depois, também com o mesmo enquadramento, vê-se Pancho Villa, expressando confusão de ideias a respeito da ordem executada. As expressões faciais de decepção com que ambos terminam a cena causa, hoje, depois de ressignificado o mito, um efeito jocoso, diferente do que pretendia o cinema da época, que seria mostrar um homem enérgico.

Em outro episódio, confirma-se a virilidade e o sentimentalismo de Villa, tal como ele está caracterizado também pela rubrica da peça que analisamos. Na narrativa "Un lindo pelao" 138 , o exército villista ganha uma batalha da qual resta apenas um capitão das tropas federalistas. Escondido, com um último projétil, ele atenta contra Villa, que é salvo por seu secretário. A seguir, o capitão é capturado e condenado ao fuzilamento. Villa admira-se da força e da coragem daquele homem cujo último pedido é a licença para fumar um charuto; o líder revolucionário pensa ainda em como seria útil se aquele homem condenado à morte servisse suas tropas. A admiração decorre do fato de que, mesmo frente ao pelotão, as cinzas não caem do charuto, pois as mãos do capitão não tremem. O caudilho, aos poucos, sente vontade de absolver o condenado. Depois da morte, Villa, em close-up, diz que sente pena, pois “era un lindo pelao”.

A essa imagem de um homem sensível, e atento às virtudes belicosas dos adversários, soma-se o caráter conquistador e galanteador. No episódio "Las mujeres de mi general", ele espera por uma mulher com a qual deve se casar por haver prometido isso ao pai dela. No mesmo ambiente, mas em espaços diferentes dos cenários, estão outras três mulheres com as quais ele vive, sem que uma saiba da outra. Por sua "postura justa", sabe que deve terminar com todas. Assim, vai até cada uma delas, mas não

\footnotetext{
138 O título do episódio é uma óbvia referência ao tema do "pelado", de Samuel Ramos, conforme apresentamos no panorama dos ensaios de interpretação do caráter mexicano no capítulo sobre Rodolfo Usigli.
} 
consegue pôr fim aos "relacionamentos", porque diante delas, descobre, após um beijo de despedida, que é "la que más quiere"139.

Na história do cinema mexicano, até a década de 30, a imagem de Villa não se vinculava à construção de um herói nacional. Somente com o filme !Vámonos con Pancho Villa!, de Fernando de Fuentes, que foi patrocinado pelo governo quando Lázaro Cárdenas era presidente (1935 - 1940), se desconstruiu a noção de bandido e inimigo da nação. Segundo Cuitláhuac Chávez (2013, p. 68), nesse filme pode-se vislumbrar a pretensão de que,

por un lado, se intenta inculcar una actitud de superioridad masculina en los espectadores, y por el otro, se quiere recuperar la figura (olvidada en ese entonces en la historia oficial) de Pancho Villa. Sin duda, las razones detrás de dichos propósitos del Estado residían en el deseo de crear la noción de nacionalidad, representar la cultura mexicana como masculina y, a la propia vez, centralizar el poder político creando concesiones entre los distintos grupos posrevolucionarios inconformes con el régimen operante.

Ao analisar sucintamente alguns aspectos marcantes da vida de Pancho Villa que o cinema de Ismael Rodríguez ajudou a sedimentar, acreditamos ter ilustrado como se forjou a "memória espectral" das projeções do Centauro del Norte recuperadas e desconstruídas em Entre Villa y una mujer desnuda.

Com efeito, tendo em vista o nome do diretor dos anos cinquenta e a indicação de que o Villa representado é o dos filmes dessa e das duas décadas seguintes, é inevitável reconhecer que, na peça em análise, a escolha de "Ismael" para nomear uma das personagens mais representativas das mudanças comportamentais (e, portanto, históricas) do México não é alheatória. Na obra, Gina abandona Adrián para firmar um relacionamento com o jovem sócio, cujos comportamentos, os modos de se vestir e as noções de mundo são totalmente diferentes daqueles que Adrián reproduz em sua vida cotidiana, amorosa e intelectual. Dessa forma, a evocação do nome de Ismael corrobora a tentativa de desconstrução do herói, pois, assim como o diretor Ismael Rodríguez foi responsável por propagar a imagem de um líder com excessos de virilidade e

\footnotetext{
${ }^{139}$ Sobre as representações das mulheres pelo cinema, além de serem envolvidas e enganadas por um Villa mulherengo, astuto e violento, outra imagem sedimentada na década de 50 foi a da mulher forte, que luta junto aos homens. Em alguns casos, como a Valentina que dá título ao filme de Rodríguez, ela é, inclusive, uma mulher independente economicamente, pois é dona de uma fazenda. La Adelita é outra representante desses estereótipos, designados de soldadera. Optamos por não avançar na comparação dessas personagens com a de Gina, uma vez que nosso objetivo recai na recriação ficcional de personagens históricos.
} 
sentimentalismo (tal qual se esperava projetar na população à época de Lázaro Cárdenas), na peça, é esse "fantasma" que se faz presente tanto para Adrián quanto para o leitor / espectador.

Se a nova formação amorosa representada por Ismael e Gina reconfigura a relação com os significados da imagem histórica de Villa propagada em determinado momento, é no flerte de Andrea e Adrián (cuja similaridade dos nomes denota paralelismo de identidades) que se constrói uma crítica aos modos de se escrever a história. No último ato, eles estão sozinhos no apartamento comprado da sócia. Nesse momento, Gina já rompeu todos os vínculos que a prendiam a seu país: desfez a sociedade; se mudou do México com Ismael e não deu notícias a Adrián, que, desconhecendo esses fatos, vai ao apartamento e é atendido por Andrea, que lança mão de vários subterfúgios para seduzilo, apesar dele não se esquecer de Gina.

O encontro, "testemunhado" pelo quadro do ex-presidente Plutarco Elías Calles que está pendurado na parede do quarto, acontece depois que Adrián volta de uma celebração à memória de Pancho Villa. Essa confluência de fatores faz com que em toda a cena paire o contraste entre os rivais políticos dos conturbados anos revolucionários e, consequentemente, o que eles representam. Na cena, portanto, Andrea e Adrián são herdeiros de um passado que ainda não foi totalmente elaborado. Nela, enquanto representante do legado histórico do avô, vislumbra-se um México que não corresponde àquele idealizado pela Revolução, amalgamada no ex-amante de Gina.

No diálogo entre os dois, a primeira referência ao passado e suas consequências aparece quando Adrián conta de onde acabara de chegar. Comenta as cenas que presenciou e dá atenção ao legado do caudilho a seus familiares, o qual, para ele, parece representar os verdadeiros desdobramentos da Revolução:

ADRIÁN (resentido): Mucha [gente en el panteón]. Como setecientos, entre hijos y nietos de Villa; y admiradores. Era como para llorar. Vinieron de todo el país y ahí estaban: morenos y con esos ojos del Centauro: azul turquesa, nítidos, como dos gotas de cielo. De cielo puro. Había algunas viudas también, ya muy muy ancianas. Y estaban quietos, los hijos, los nietos, las mujeres de Villa, mirando la tumba. ANDREA: Gente humilde.

ADRIÁN: Claro.

ANDREA: ¿Analfabetos?

ADRIÁN: Muchos, supongo. Como para llorar, en serio.

ANDREA: Pues sí. ¿De qué sirvió la Revolución, la lucha del general Villa, si sus nietos están igual de chingados que de escuincle? (p. 202). 
Por outro lado, o reconhecimento da falência da Revolução, expresso abertamente nas palavras de Andrea, também surge no relato de Adrián ao reconhecer o analfabetismo e a permanência da memória por si como fatores negativos desse legado. Imediatamente, conclui: "No sabes lo que dices. Toda su descendencia adora su memoria. Es lo único valioso para ellos: la memoria del Centauro.” (p. 202). A neta de Calles insiste na afirmação de que toda a luta parece ter sido em vão. Adrián também mantém a convicção de que a memória continua viva e que Villa saiu do túmulo e continua “cabalgando por ahí. Y bueno, por ahí anda, ¿no?, cabalgando en nuestra imaginación, al menos. En nuestros ánimos de redención.” (p. 103). No entanto, à medida que parece ceder aos encantos da mulher que procura seduzi-lo (lhe serve um chá, massageia-o, convida-o para dançar até que o beija), Adrián enfraquece e confessa:

\begin{abstract}
ADRIÁN: De veras no sé qué hacer conmigo mismo. Lo de Gina, haber terminado lo de Villa también. Me quedé sin proyecto de vida... No hay héroes vivos alrededor nuestro; la Revolución está muerta: la de 1910 la asesinó precisamente tu abuelito. (Grita de dolor por un punto de tensión que Andrea le toca).

ANDREA: Sopla, sopla, sopla.

ADRIÁN: (de plano llorando): Y la revolución de mi generación se la secuestró la derecha para deshuesarla, descojonarla... Así que sí, "me agobia la mediocridad". Me agobia voltear y ver la punta de mercaderes merolicos que detentan el poder en nuestra época. Puta madre, no sé de dónde saqué que el mundo podía ser justo, y no el compendio de pequeñeces e indecencias que me dedico a delatar en el periódico desde hace veinte, veinticinco años. Estoy exhausto, Gina. (p. 207).
\end{abstract}

Percebemos a transformação sofrida por Adrián: das atitudes sexistas, proativas, comumente atribuídas ao homem, agora deixa transparecer sentimentos de tristeza e desilusão, pois está assolado por decepções na vida amorosa e intelectual. Sentese impotente diante das forças sociais que têm o poder estabelecido. Ele, alguém que foi um materialista dialético, conforme se define em algum momento, ao término da escrita de seu romance, sente-se órfão porque já não consegue ancorar suas ações no passado.

A virilidade demonstrada no relacionamento com Gina cede lugar a uma passividade que parece levá-lo a ceder pouco a pouco aos encantos de Andrea. Ela, como última estratégia de sedução, oferece ao historiador o arquivo pessoal que guarda de herança do avô. Abraçando Adrián, explica que "hay papeles inéditos, bastante sorprendentes. Hay documentos que en su época fueron secretos.” (p. 208), os quais poderiam provar que seu avô havia sido realmente o mandante do assassinato do 
combatente - algo que, para a historiografia mexicana até a biografia de Kratz, era tema de intensos debates. Diante dessa proposta, Adrián, mesmo demonstrando consciência de que levar à luz os documentos inéditos sobre Plutarco Elías “lo haría mierda”, prefere não aceitar a proposta.

A intepretação da postura de Adrián diante disso é de difícil compreensão. Apostamos na probabilidade de que ele recusa a oferta porque prefere manter viva a imagem do caudilho traído. Dois aspectos de seu caráter nos levam a seguir essa linha. Já vimos que ele rejeita a fase de preparação de seu livro, isto é, a fase de pesquisa, de reflexão, de identificação de elementos que poderiam compor a narrativa. Pelo contrário, sente-se estimulado a escrever, de uma vez, as ações de Villa, sua entrada triunfante na Cidade do México. Nesse sentido, deve ser destacado também que Adrián é um historiador que escreve um romance, ou seja, ele não atua no campo científico, analítico, mas no universo da ficção. Nela, o compromisso com a verdade, isto é, a identificação factual entre o representado e a representação, não ocupa o primeiro plano das preocupações. Com efeito, aceitar que a proposta de Andrea de "sistematizar el material confidencial de don Plutarco... y despacio, con fechas, con documentos, y para la Historia, con H mayúscula" (p. 208) seria correr o risco de provar a inexistência da ação de Calles no assassinato, algo contrário àquilo em que Adrián acredita.

Assim, parece ser plausível afirmar que o pressuposto de que a Revolução não se concretizou por causa dos traidores é mais reconfortante do que descobrir as origens da falha em outros pontos, tais como a própria estrutura do movimento. Dessa forma, apostamos que a negação de Adrián aos documentos e encantos de Andrea significa antes de tudo o medo de "passar a limpo" a história, uma vez que toda pesquisa meticulosa pode proporcionar descobertas que escapam às hipóteses e às ideias consolidadas.

\subsection{Contar a história que não serve mais}

Retomando os pressupostos com o qual temos trabalhado nesta pesquisa, poderíamos afirmar que o jogo teatral que coloca em xeque a realidade e a ilusão a partir do questionamento dos referentes históricos se sedimenta de vez em Sabina Berman. A sobreposição de tempos provoca efeitos enriquecedores para dramaturgia mexicana. Não se trata de discutir, através da representação de um evento histórico, algum aspecto do 
presente. Também não existe a transposição temporal em ambientes diferentes de modo a causar a simultaneidade de tempos e ações. Presente e passado convivem nas cenas.

Essa convivência, porém, está repleta de conflitos e problemas do mundo contemporâneo. O embuste da política, as forças e formas do capital, a posição da mulher na sociedade, as divergências entre as gerações e o lugar dos intelectuais são alguns temas que perpassam a obra de Sabina Berman. O contato com a história intensifica esses conflitos. A preocupação que parece então se manifestar é a seguinte: se, por si só, os problemas apresentados não podem ser resolvidos facilmente, que auxílio a história poderia oferecer para a resolução desses conflitos? A obra de Sabina Berman aponta justamente para a negação de certa maneira de se fazer história, a qual se caracterizaria pela exaltação irrefletida de heróis nacionais e pelo continuísmo de ideias já consagradas.

Dessas incertezas decorrem a paródia, a ironia e o cômico de personagens e eventos históricos, recursos que visam a manifestar a descrença em projetos políticos e ideológicos que efervesceram na mentalidade de seu país ao longo do século XX. Ao deslocar esses referentes para o presente, ela não procura trazer uma espécie de conhecimento "útil" e "necessário" que permitiria encontrar soluções para, por exemplo, a identidade nacional, conforme almejava Rodolfo Usigli, nem de denúncia, no caso de Leñero. Berman parece estar menos preocupada com o evento em si. Interessa-lhe sobretudo a sensação de que o passado permanece como algo estanque e que, de tanto se repetir, é vivenciado como real.

Essa sensação é emblemática nos casos do passado pós-revolucionário e préconquista, momento em que a recuperação ufanista do passado indígena é questionada. Sem a consciência crítica e a ressignificação daquele momento, não há como servir de exemplo a ser seguido no presente. Da mesma forma, a crítica a Revolução é feita denunciando-se a sucessão presidencial. Enquanto os políticos evocaram, durante longos períodos, os ideais revolucionários, criou-se, no imaginário, a impressão de que o futuro só chegaria caso o passado retornasse. Em outras palavras, a política criou no imaginário a ideia de que o conhecimento da Revolução seria condição essencial para que ela se realizasse.

É fundamental observar, do ponto de vista da criação ficcional dramática, que os recursos utilizados pela autora se aproximam muito do que realizaram os dois autores analisados anteriormente: a presença de personagens "encarregados" de escrever a história, inserção de documentos, paralelismo temporal e manutenção de unidades 
dramáticas mesmo tendo ela utilizado recursos narrativos nas primeiras obras de sua carreira (En el nombre de Dios e Trotski, por exemplo). 
PARTE III - O corpus em perspectiva 


\section{Capítulo 6 - Transformações da dramaturgia via didascálias}

A proposta deste capítulo é verificar como as didascálias contribuem para a concepção cênica das obras do corpus selecionado. Mais especificamente, move-nos a curiosidade de compreender as estratégias dos dramaturgos para gerar, no plano do texto literário, os efeitos de sentido que pretendem causar no palco. Uma vez que a prosa é a forma da história e o diálogo a do drama (SZONDI, 2001), entendemos ser necessário vasculhar como a diminuição gradual das rubricas se manifestou no contexto estudado nesta pesquisa.

Mantendo a perspectiva cronológica que até este momento nos orientou, mas optando por uma abordagem metodológica comparativa, começaremos com Corona de sombra, em que, logo após a indicação das dramatis personnae, são elencados o tempo e o espaço de cada um dos atos:

\section{ESCENARIOS}

Acto I

Doble salón de un castillo en Bruselas - 1927 (19 de enero) (Derecha) Alcoba de Carlota en Miramar - 1864 (9 de abril) (Izquierda) Alcoba de Maximiliano en Chapultepec - 1864 (12 de junio)

(Derecha) Salón de Consejo - 1865

Acto II

(Izquierda) Boudoir de Carlota en Chapultepec - 1866 ( 7 de julio)

(Derecha) Salón en el Palacio de St. Cloud-Agosto de 1866

(Izquierda) Despacho del Papa en el Vaticano - 1866

Acto III

(Derecha) Salón en el castillo de Miramar - 1866

(Izquierda) Salón en el castillo de Bruselas - 1927

(Derecha) Celda de Maximiliano en el Convento de Capuchinas - 1867

(19 de junio)

El doble salón del principio - 1927

(USIGLI, TC II, p. 147-148).

Procedimento semelhante acontece em Corona de fuego. A rubrica indica que o primeiro ato se passa em Tuxakhá e em Itzamkanac, "entre el 27 y el 28 de febrero del año de 1525" (USIGLI, TC II, p. 776). Por sua vez, Corona de luz também contém a mesma estratégia: "La acción el año de 1529, en el vestíbulo del monasterio de San Jerónimo de Yuste”. (USIGLI, TC II, p. 842). Nessa peça, o segundo ato acontece " $a$ principios de 1531 [...] en el Obispado”. (USIGLI, TC II, p. 865). Por fim, o terceiro se passa “en México, la mañana del 12 de diciembre de 1531” (USIGLI, TC II, p. 893). 
A precisão histórica com que se delimitam as ações assemelha-se ao que acontece em obras de Vicente Leñero, tais como Martirio de Morelos ("En Tezmalaca, México y Ecatepec, del cinco de noviembre al veintidós de diciembre de 1815” LEÑERO, TC I, p. 546) e em La noche de Hernán Cortés, cuja cenografia está projetada para acontecer em quatro tempos e locais diferentes e simultâneos:

Sevilla. Una buhardilla en una casona de Castilleja de la Cuesta, Sevilla, 1547. También podría ser un estudio-biblioteca en 1990 [...]

Coyoacán. Un salón en la casona-palacio de Hernán Cortés, en Coyoacán, Nueva España, Ciudad de México, 1522. [...]

Cempoala. Adoratorios totonacas y Templo Mayor en la ciudad de Cempoala, 1519. [...]

Cuba. Distintos aposentos en Santiago de Cuba, 1514.

(LEÑERO, TC II, p. 424).

Já em Sabina Berman encontramos modificações no procedimento. En el nombre de Dios $^{140}$, o tratamento histórico segue ainda bem de perto aquele elaborado pelos demais autores e pela maioria dos dramaturgos que optaram pelo drama histórico, de modo que a didascália inicial situa a ação "de 1579 a 1594, en la Nueva España." (BERMAN, 2004, p. 329). Porém, a partir de Águila o sol, o prefácio oferece somente informações panorâmicas: "Águila o sol trata de los días que transcurrieron desde la llegada de los españoles a las costas del imperio mexicano hasta el asesinato del emperador mexica Moctezuma, en la capital imperial.” (BERMAN, 1985, p. 225).

Verificamos assim claramente que de Usigli a Berman desaparece a preocupação com dados históricos precisos. Se o criador da trilogia das coroas fazia questão de situar historicamente a época e o ambiente, a escritora contemporânea, ao longo de sua trajetória, dispensa o tratamento e reduz as indicações aos fatos. No caso de Leñero, a complexidade se acentua paulatinamente, a ponto de sobrepor tempos e espaços diversos, tal como em La noche de Hernán Cortés, cujo argumento se passa em Sevilla, no ano de 1527 ou 1990.

Essas transformações na didascália implicam formas cênicas de fazer chegar (ou não) as informações ao espectador. Como pudemos observar nas análises das peças, nem sempre a contextualização do período histórico era comunicada claramente à plateia

\footnotetext{
${ }^{140}$ Embora na edição de Puro Teatro (2004) a data de primeira publicação apareça como 1991, sabemos que a gênese de composição remete a anos anteriores, com Herejía, em 1983.
} 
nem era mostrada por recursos épicos, tais como cartazes, vozes em off, projeções etc. Isto é, nas peças e autores aqui estudados, quase nunca se anuncia, no plano cênico, a projeção temporal do plano literário.

Nos casos de Rodolfo Usigli e das primeiras obras de Sabina Berman, a maneira de informar o público sobre o contexto em que a ação se desenrola é recorrendo à inserção dos dados na fala de algumas personagens. Um exemplo é En el nombre de Dios, em que Don Luis de Carvajal El Viejo aparece na segunda cena do primeiro ato, apresentando-se ao público: "vine al mundo hace ya cincuenta y un años - en 1539, pues -, allá del otro lado del océano, por supuesto, en la Villa de Magodorio, en la raya de Portugal.” (BERMAN, 2004, p. 331). O mesmo recurso épico se repete na cena seguinte com Felipe Núñez: “Desde mis diez años... Desde mis diez años, cuando, quedándome huérfano, entré al servicio de don Luis.” (p. 332). Porém, essas narrativas dizem respeito a tempos pretéritos; não é possível, pelas falas, saber em que época se situa o presente da enunciação. Dessa forma, cabe ao espectador (e em alguns casos até mesmo ao leitor) recorrer à narrativa historiográfica para situar o momento da enunciação. ${ }^{141}$

No caso de Usigli, se em El gesticulador o presente da ação era dado desde a didascália inicial (“Época: hoy”142 - USIGLI, TCI, p. 727), em Corona de fuego, além das especificações tempo-espaciais da rubrica, é por meio dos coros de espanhóis e mexicanos que o espectador se situa no presente dos acontecimentos representados. As duas primeiras longas intervenções narram, cada uma sob sua perspectiva, os episódios pretéritos até o momento da ação.

\section{EL CORO DE ESPAÑOLES. -}
¡Ay, mil, quinientos veinticuatro, y día
Doce de octubre de oro en la meseta,
el mismo en que Colón toca la meta
indiana que a los Reyes prometía!
$[\ldots]$
Ya el veintisiete de febrero apunta
cuatro meses sin sueño han transcurrido,
octubre, noviembre y diciembre se han ido
igual que enero, en a marcha conjunta.

\footnotetext{
${ }^{141}$ Em um texto como esse de Sabina Berman, o conhecimento historiográfico prévio torna-se mais importante porque a peça está repleta de digressões e avanços temporais.

${ }^{142}$ Seria importante ampliar, filosoficamente, o impacto do "hoje" nessa peça e em outras que assim se expressam. Tarefa que foge aos propósitos deste trabalho. A necessidade decorre do fato de que diferentes tempos estão presentes no advérbio. No caso de El gesticulador, foi escrita em 1938, levada ao palco pela primeira vez em 1947. Nos tempos atuais, por outro lado, trata-se de um clássico cuja força está justamente em que, representando um momento específico da história, dialoga com o contemporâneo de maneira intensa.
} 
[...]

Al fin hemos llegados a Tuxakhá,

tierra de Pax Bolón, monarca amigo,

y volveremos a ver la luz de día.

EL CORO DE MEXICANOS. -

¡Ay, y cuatro años ya de cautiverio!

Soles oscuros y lunas de fuego

[...]

Negro destino del señor Cuauhtémoc, destino al fin de padre de los hombres

que sólo quiso nación mexicana.

Siete meses de enero a agosto,

siete meses no más de imperio

[...]

No sé por qué turban mis sentidos

y veo negros nubarrones ahora

que llegamos al fin a Tuxakhá. (USIGLI, TCII, p. 777 - 782).

Em Corona de fuego, a opção por enunciar a marcação histórica através das falas das personagens decorre do gênero escolhido, a tragédia. Os Coros assumem a função de "narrar" o cenário e a localização espaço-temporal tal como se fazia no teatro clássico. Solução diferente encontramos em Corona de sombra, a primeira da trilogia. Ali, o historiador Erasmo Ramírez é o responsável por ancorar o momento em que se desenvolve a ação, 1927. Mas depois, enquanto Carlota Amalia narra os acontecimentos da época em que era Imperatriz do México, será novamente a voz didascálica a demarcar o tempo, auxiliada pelo apagar e acender das luzes.

Porém, em outros momentos não é possível precisar o tempo, isso porque outros recursos são utilizados. Na segunda cena do primeiro ato, lemos o seguinte: “[Carlota] es joven ahora, como en 1864." (USIGLI, TC II, 161). Apesar do "ahora" disparar o movimento de retorno ao passado, a estratégia para mostrá-lo não se faz pela enunciação verbal da personagem que se coloca de frente para o toucador e, agindo como se se penteasse, retira a peruca caracterizadora de sua ancianidade. Na continuidade da cena, em que interage com Maximiliano, nenhum dos dois se refere ao ano de 1864. A referência é apenas a uma data anterior: "MAXIMILIANO: [Napoleón] ¿No invadió a México en '62?' (USIGLI, TC II, p. 164). Verificamos, portanto, que, se por um lado a data enunciada por Maximiliano marca que o diálogo ocorre em um momento posterior, apenas duas formas dariam acesso efetivo à contextualização do ano da enunciação: a voz didascálica ou o conhecimento prévio da historiografia.

Ainda nessa peça, na segunda cena do último ato, Carlota está recobrando a consciência. Sua narração dos eventos passados possibilita lançar luz sobre sua vida atual. 
Enquanto reelabora tudo o que disse anteriormente, o historiador faz desfilar uma série de personagens históricas, bem como suas respectivas datas e locais de falecimento. Todas as personagens são conhecidas por Carlota nos momentos de sua juventude e do esplendor de seu poderio. As informações, nomes e datas outorgam certa peculiaridade à cena, pois permitem apresentar todo o histórico dos acontecimentos que sucederam à morte de Maximiliano e ajudam a caracterizar Erasmo Ramírez como um historiador mecânico, que reproduz cronologias e incapaz de articular os fatos para explicá-los.

Essa estratégia de situar, ora pela rubrica ora pelas personagens, as datas exatas que possibilitam historicizar os eventos representados também aparece na terceira peça da trilogia usigliana. A novidade agora está na justaposição das informações históricas sobre as intervenções do autor. Na apresentação do rei Carlos V, por exemplo, explicita-se um uso incomum das didascálias, principalmente se comparadas às anteriores:

Carlos V de Alemania y I de España viene vestido con un traje pardo de viaje y se asemeja mucho a sus mejores retratos. Es ya el padre de la cristiandad por encima de Clemente VII; el señor del mundo por encima de Francisco I y de Enrique VIII: lúcido, preciso, guerrero pacifista. (USIGLI, TC II, p. 845).

Apresentado como aqui está, recortado do todo da peça, o leitor poderia esperar a presença de Clemente VII, Francisco I e Enrique VIII na ação. Porém, nenhum deles é representado. Embora por meio da referência ao papa e aos reis seja possível captar o "espírito do tempo" em que se passam as ações, essas informações não chegam ao espectador em nenhuma cena ou ato, pois nenhum gesto, recurso ou personagem as mostra ou expressa.

É importante destacar ainda que o trecho acima parece ser a consequência de outro recurso que, embora menos frequente, merece atenção. Trata-se do estabelecimento de uma cumplicidade com o leitor, resultado da assunção de sua perspectiva, através da voz didascálica. ${ }^{143}$ Corona de luz e En el nombre de Dios deixam entrever essa conjugação de rubrica e público. Para isso, insere-se a primeira pessoa do plural. Assim, por exemplo, a quarta cena do segundo ato da peça de Usigli inicia-se com a seguinte rubrica: "primeramente vemos que un candelabro con bujías encendidas es instalado en una mesa del salón izquierda.” (USIGLI, TC II, p. 197). Já na peça de Berman, na cena

${ }^{143}$ Luiz Fernando Ramos (1999, p. 74), lembrando o ensinamento de Issacharoff em "Voix, autorité, didascalies", afirma que "uma das características do discurso didascálico é exatamente uma terceira pessoa que é uma "não-pessoa"'. A partir desse pressuposto, podemos agora ampliar algumas questões levantadas no capítulo 2.5. Com o sintagma "voz didascálica" designamos a presença de um discurso que se manifesta fora das falas das personagens, mas que dialoga com elas. Nesse sentido, a didascália não indica algo para fora da ficção, mas faz parte dela. 
de apresentação de Don Luis El Viejo, a rubrica se exprime assim: “[Él] declara ante los inquisidores - no los vemos: en todo caso somos nosotros, el público —." (BERMAN, 2004, p. 331). O recurso aparecerá ali em outras três oportunidades.

O uso da primeira pessoa do plural nesses casos corrobora a necessidade de reexaminar o pressuposto de que a rubrica seria a expressão da voz autoral. Os trechos apresentados alcançam efeitos discursivos que extrapolam a indicação cênica. Em Usigli, a utilização dá a entender que espectador e palco se mantêm em suas posições, isto é, subentende-se a permanência da chamada quarta parede. A expressão "Vemos que" coloca os leitores em atitude de observação. Já a expectativa de Berman é outra. Nela, o procedimento é semelhante ao efeito de distanciamento brechtiano, mas no sentido oposto. Não se provoca a desvinculação entre ator e personagem, mas sim a cumplicidade entre plateia e palco através da personagem. Isso coloca os espectadores em situação de inquisidores e, por conseguinte, sinaliza para uma crítica a determinada interpretação da história, ao mesmo tempo em que alerta sobre os julgamentos históricos. Assim, a presença da primeira pessoa do plural põe em xeque um dos preceitos fixados pela crítica dedicada ao texto dramático, segundo a qual a rubrica enuncia, na terceira pessoa e no presente, os gestos e movimentos das personagens.

Porém, em muitas indicações de Usigli e Leñero aparecem com frequência certos modalizadores discursivos que demonstram titubeio da voz didascálica frente aos atos. Um exemplo pode ser visto em Los albañiles, de 1969. Ali Leñero nos mostra um cenário assim indicado: "el recinto de investigación policial [...] ocupa el proscenio, quizá sólo una parte del proscenio.” (TC I, p. 51). Nesse momento, vemos que existe um modalizador indicativo de dúvida (na verdade por meio do qual transparece mais uma concessão). Da mesma forma, é apresentada a personagem Patotas, "un albañil de aspecto paupérrimo, tal vez el más miserable y primitivo de la obra." (p. 55). Estratégia semelhante é usada ainda na apresentação da personagem Isidro, o principal suspeito da morte de Don Jesús. "Isidro [un muchacho de quince o dieciséis años] puede tener allí [frente al cadáver] una hora o escasos minutos.” (p. 54). Todas essas indicações contrastam com a ideia de que as rubricas deveriam demonstrar diretamente os fatos que, no palco, seriam mostrados para o espectador em forma de suspense, surpresa e expectativa.

Esses exemplos de Leñero se estendem para seus dramas de extração histórica e ali se multiplicam. A personagem de Morelos, na peça de 1981 que leva seu nome, "parece interesarse" ao se aproximar do grande livro. (TC I, p. 546). Na obra sobre a 
Conquista (que é de 1992), "sólo los personajes de Hernán Cortés y el secretario (y tal vez el enano) poseen una identidad única." (LEÑERO, TC II, p. 425).

A recorrência a expressões que denotam dúvida ou titubeios para caracterizar as personagens está presente também em peças de Usigli. O protagonista Erasmo Ramírez, cuja composição cenográfica está destinada a se assemelhar a Benito Juárez, tem "mediana estatura, que por un poco sería baja” e sua caracterização é complementada novamente por modalizadores apreciativos: "su corbata de lazo, anticuada y mal hecha, completa una imagen un tanto impresionista y vaga que juraría uno haber visto hace mucho tiempo." (USIGLI, TC II, p. 149).

Essa forma de dizer que coloca na leitura um jogo entre a objetividade tradicional das rubricas e a subjetividade autoral, expandindo o olhar da voz didascálica e do leitor, também fora explorada em El gesticulador. Na descrição da casa onde se instala a família Rubio, a forma do verbo “dizer” sugere a posição de alguém inseguro com relação ao que está expressando: "Demasiado pobre para tener mosaicos o cemento, la casa tiene un piso de tipichil, o cemento doméstico, cuya desigualdad presta una actitud-dijérase - inquietante a los muebles.” (USIGLI, TC I, p. 728).

Essa espécie de voz intermediária (um narrador?) que oscila entre a apresentação e a apreciação das personagens também se manifesta em Corona de luz para introduzir o Frei Motolinía. Seguida da apreciação da roupa, ela outorga à rubrica uma funcionalidade que extrapola a indicação do vestuário: "entra por la izquierda un fraile que, debiendo llevar hábito pardo, lo lleva azul como todos sus hermanos de Orden a causa de faltar la tela parda en Nueva España, según parece.” (TC II, p. 868). No trecho, além do titubeio da voz didascálica manifesta-se o recurso metalinguístico, porque expõe a dose de imaginação permitida aos gêneros literários de extração histórica quando se afirma que o uso das batinas de cor parda decorria da falta de panos azuis para confeccioná-las.

O mesmo tipo de didascália é usado em Entre Villa y una mujer desnuda. $\mathrm{Na}$ descrição das personagens de Entre Villa y una mujer desnuda, isso se torna mais evidente: "Gina no tiene que ser especialmente atractiva, pero uno desearía de inmediato tenerla de amiga.” (2004, p. 159). À semelhança de Andrea com o ex-presidente Plutarco Elías Calles, a voz didascálica assim se expressa:

Si esto parece indicar que no es una mujer atractiva, lo primero es invitar al lector a revisar las fotografías del guapo Plutarco; lo segundo es asegurar que tiene un encanto físico y una divertida tendencia mental a la ironía. (p. 160). 
Da mesma maneira, En el nombre de Dios introduz desta maneira a descrição do cenário: "Se supone un escenario vacio." (p. 329).

"Es asegurar”, “se supone”, "quizá”, “tal vez”, "según parece”, “dijérase” etc. todas essas expressões cumprem a função de ponderar a voz que enuncia e causar cumplicidade da voz didascálica com o leitor, provavelmente indicando que o mesmo sentimento deva ser estendido à relação com os espectadores. Funcionam também como recurso singular de inserção de uma voz dentro de um discurso que, em aparência, seria impessoal, neutro, objetivo. Com efeito, a recorrência com que estas marcas aparecem nas didascálias de nosso corpus coloca o texto "secundário" num estatuto tão importante quanto o dos diálogos. Dessa forma, a dimensão literária do texto dramático se torna tão complexa quanto sua faceta espetacular, no sentido de que o procedimento demanda do diretor e dos atores o desafio de realizar, na montagem e na performance, algo além da reprodução das falas. Todas essas estratégias enriquecem as obras e dão sabor especial à leitura ao mesmo tempo em que exigem de atores dedicação maior na hora de compor as personagens.

Porém, encontramos ainda nesses dramaturgos, outra estratégia de rubrica bastante singular que merece ser tratada à parte, porque atinge o alvo das preocupações deste trabalho: a relação entre ficção e história.

\subsection{A narrativa como estratégia de rubrica}

No tópico anterior, identificamos estratégias de rubrica fulcrais na arquitetura literária do corpus: precisão de datas e locais em que ocorrem os eventos, mas que não são enunciados na representação; estabelecimento de uma cumplicidade entre voz didascálica e público leitor / espectador; e presença de modalizadores discursivos que sugerem dúvida, insegurança ou titubeios dessa voz. Paralelamente a elas, chama atenção a invasão das rubricas com expedientes típicos da prosa romanesca, sobretudo em Rodolfo Usigli e Vicente Leñero. Esses procedimentos merecem ser tratados à parte porque tocam no centro da problemática textual da interlocução entre história e literatura. Neste tópico pretendemos demonstrar quais são esses recursos e em que medida eles podem realmente ser chamados de narrativos.

É necessário aclarar desde já que não nos referimos a meios de historicização, isto é, àqueles que dão caráter épico ao texto cênico. Nesses casos, historicizar é distanciar. 
Como vimos até aqui, as ferramentas narrativas dentro do texto dramático procuram envolver o leitor e torná-lo cúmplice e testemunho do tema histórico. A nosso ver, portanto, as estratégias supramencionadas originam-se de estruturas das formas romanesca e historiográfica. O uso do pretérito dentro das didascálias, a citação de documentos e a ambientação do conflito estão entre estruturas prosaicas que invadem o texto dramático.

Analisando esses procedimentos nas obras de Rodolfo Usigli, detectamos que, mesmo sem pretender fazer teatro de costumes nem reviver ou resgatar formas teatrais populares, suas peças conformam um mosaico da história passada e contemporânea aos anos de 1930 a 1960. Alguns trechos de El gesticulador parecem ter sido motivados pelo afã de representar o típico e o local como acontece num número expressivo de romances e novelas cortas latino-americanos do século XIX. ${ }^{144}$ De fato, na abertura da peça nos deparamos com uma longa didascália que poderia ter sido retirada das melhores páginas de prosa "costumbrista". Na descrição da casa dos Rubio, "hay una salida hacia el solar característico del Norte”, e a modéstia dos donos está representada na simplicidade do lar que nem sequer lhes permite ter "la fábrica de adobe, frecuente en las regiones menos populosas del Norte." No início da trama, os sinais de pobreza da cena são evidentes: Julia, que "no es propiamente la tradicional virgen provinciana” (USIGLI, TC I, p. 728), está sobre uma cadeira, pendurando na parede uma "lámina”, uma espécie de quadro de pouco valor e feito sem moldura. No segundo ato, Navarro, “viste, al estilo de la región, ropa muy ligera.” (USIGLI, TC I, p. 749).

Mais à frente, o delegado Estrella e os demais políticos locais também são apresentados com um cuidado fotográfico:

Estrella es alto, delgado, tiene esas facciones burdas con pretensión de raza. [...] Tiene la piel manchada por esas confusas manifestaciones cutáneas que atestiguan a la vez el exceso sexual y el exceso de abstención sexual. Los otros son norteños típicos [...] Todos bebedores de cerveza, campechanos, claros y decididos. (USIGLI, TC I, p. 758).

Nesses exemplos, a descrição dos costumes (ainda que muito estereotipada), e a elaboração quase metafórica das características físicas dos personagens expostas no trecho mais longo proporcionam material suficiente para afirmarmos que as rubricas não indicam meramente como o espetáculo deverá ser montado. Elas apontam para uma

\footnotetext{
${ }^{144}$ Sobre essa questão remitimos, além do clássico estudo de Doris Sommer (2004), ao livro La novela corta en el primer Romanticismo mexicano (1998), com estudos preliminares de de Celia Miranda Cárabes e Jorge Ruedas de la Serna.
} 
subjetividade em que o intuito de encenar algo típico, quase caricato e pitoresco da realidade nacional, está aclimatado ao contexto nacionalista de sua criação. Há nelas um poder informativo e sugestivo. Informativo porque permite dar a conhecer uma realidade "tradicional" e sugestivo porque parece ser quase uma piscada irônica que suspende o avanço da ação para se impor como uma reflexão acerca de sua própria funcionalidade discursiva.

Estratégia similar põe em movimento a apresentação das personagens de Corona de luz, que, talvez por se tratar da última peça da trilogia e corresponder ao auge da maturidade de Usigli, é a que mais abusa do procedimento. Do bispo Juan de Zumárraga faz-se a seguinte descrição: "cuarto de trabajo u oficina del flamante primer Obispo de la Nueva España Fray Juan de Zumárraga, vasco, enérgico y testarudo, varón de palabra recia y, a pesar de todo, de pocas palabras." (USIGLI, TCII, p. 868). Por sua vez, o Padre Bartolomé de las Casas é indicado como "un fraile dominico, con la figura llena de autoridad, gallardía y española cólera, siempre en estado de ebullición." (USIGLI, TCII, 869).

Entre a "vasca energia" de Zumárraga e a "espanhola cólera" de Las Casas e aqueles "costumes típicos" de Julia, Navarro e Estrella há um intervalo de mais de vinte anos. Estamos diante de uma estratégia de rubrica cuja finalidade é a construção de uma perspectiva interpretativa e crítica da história representada a partir de um processo criativo que privilegia a construção literária tanto quanto a espetacular. No tocante ao diálogo com a história, essa maneira de escrita das rubricas assinala a busca por novas formas de expressão cujo intuito é fixar supostos apanágios nacionais.

Passada a intensidade do período nacionalista, outros recursos se aglutinam a esses. Veremos, por exemplo, que os marcadores temporais, tão frequentes na narrativa prosaica, irão aparecer com diferentes finalidades nas obras de Leñero. Em Los albañiles, eles introduzem uma atmosfera de expectativa e suspense logo no início:

\begin{abstract}
ACTO PRIMEIRO
Son poco más de las seis de la mañana. Al parecer, el edificio se encuentra totalmente deshabitado. La iluminación que asciende de manera muy lenta descubre, en uno de los niveles superiores de la construcción, el cuerpo de un hombre tendido, muerto. Es evidente que ha sido asesinado: la sangre aún fresca mancha su cabeza y sus ropas y las zonas próximas donde yace. (LEÑERO, TC I, p. 53).
\end{abstract}

Embora nessa peça não exista preocupação com nenhuma fidelidade histórica, chama atenção a marcação do horário seguida do modalizador "al parecer". O efeito de 
expectativa criado nessas primeiras linhas se assemelha em alguma medida a determinadas estratégias do romance policial. Notamos ainda, a iluminação demorada sobre o cadáver na solidão do prédio. Pelo uso do pretérito composto ("ha sido asesisado”), se deduz que o evento desencadeador da ação aconteceu há pouco. Esse modo verbal parece desequilibrar a experiência de leitura de textos dramáticos porque, no teatro, como o tempo da leitura e o do desenrolar dos fatos é simultâneo (HAMBURGER, 1986), prevalece o presente ${ }^{145}$.

Em Pueblo rechazado, escrita no ano anterior, a técnica já era explorada em vários momentos. No primeiro ato, enquanto o Sacerdote apresenta ao Coro de Católicos a vida no mosteiro, há uma fala extensa. Apesar de cumprir a tradicional função de sinalizar as ações, a sintaxe da rubrica explicita a simultaneidade dos gestos que deverão ser executados: "Mientras el sacerdote hablaba, los miembros del coro de católicos se han dispersado por el escenario observándolo y examinándolo todo con admiración y respeto.” (TC I, p. 12). Mais adiante, antes do diálogo do Analista com o Prior, a voz didascálica informa que "Los monjes que vimos durante la visita del prior no han variado sensiblemente de postura." (TC I, p. 17). Nos dois trechos, a presença do pretérito mais uma vez revela intenções narrativas.

Estamos diante de um jogo entre o desenrolar da ação e a quebra dos fatos para contar algo anterior. É justamente o contrário de uma indicação cênica elaborada simplesmente para ser montada. A título de comparação, podemos citar La noche de Hernán Cortés, em que a função injuntiva se sobrepõe à narrativa mesmo usando recursos sintáticos de simultaneidade temporal: "Durante el desarrollo de la historia, el personaje de Hernán Cortés cambia de edad y de actitud, según el lugar en que se encuentra, con extrema celeridad." (TC II, p. 424). Facilmente identificamos aqui a intenção de sinalizar como deve ser a representação. Além disso, o tempo verbal predominante é o presente.

Retrocedendo um pouco na cronologia, constatamos que a estratégia de redigir a rubrica lançando mão de alguns recursos peculiares da prosa narrativa é impactante em Corona de luz. Nessa peça, nos defrontamos com algumas variações do recurso que, em conjunto, outorgam um viés peculiar à peça. Uma delas são as digressões históricas. Ao apresentar o mosteiro em Yuste e as personagens de Carlos V, por exemplo, a voz didascálica percorre aspectos históricos que, se entrassem na composição da ação, certamente quebrariam a unidade, preceito tão cultuado por Usigli.

\footnotetext{
145 Recordemos ainda o ensinamento de Käte Hamburger segundo o qual o pretérito perfeito é uma convenção da arte romanesca e não indica, necessariamente, que algo passou.
} 
O "Prólogo Político" faz uma retrospectiva do mosteiro de São Jerônimo de

Yuste:

fundado como ermita y establecido como capilla en 1407 por bula otorgada por el Papa Benedicto XIII; privado de bendición por el Obispo de Palencia, y luego restituido a la posesión de sus bienes y reorganizado como núcleo jerónimo con apego a las reglas de San Agustín. Está situado en Cáceres, en la región de Extremadura, medianera en la ruta que Carlos V de Alemania y I de España sigue ese año para hacerse coronar en 1530, tras una lucha sin tregua ni ley, emperador de los romanos. (TC II, p. 842).

A voz que se expressa nesse trecho conta toda a história do mosteiro, detalhando inclusive as etapas de sua oficialização, avança no tempo (se situa em 1529, mas anuncia algo que acontecerá em 1530) e comenta os antecedentes das lutas que possibilitaram a ascensão de Carlos I de Espanha. A continuação passa das informações históricas para uma descrição quase impressionista do lugar:

Atardece, y al fondo de las arcadas puede percibirse una perfumada visión de naranjos, como la sombra verde de un boscaje, fuera del monasterio, y la luz, suave y densa a la vez, que los descubridores flamencos de la pintura al óleo pueden comunicar todavía al visitante de exposiciones y museos después de casi cinco siglos. El vestíbulo está desierto, y la profesional paz monástica cubre el ambiente como aceite. Aquí no pasa nada, ni nada se mueve. El aire se desliza con suave servilidad incapaz de agitar una hoja, de suscitar un deseo, de avivar una conciencia. De pronto se quiebra todo como un cristal finísimo y muy grueso - cristal de roca - sobre el que alguien dejara caer un enorme martillo. (TC II, p. 842-843).

A minúcia sensorial figurada pelas cores, a evocação do perfume das laranjeiras e a sensação de paz interior contida na analogia do azeite, além de informar que "deve ser criado o ambiente dessa forma", colocam desafios ao encenador ao mesmo tempo em que ampliam o horizonte de criação cênica. A finalidade da descrição é produzir paulatinamente na leitura a sensação de estar adentrando no ambiente, tanto que, depois de uma exposição histórica e da criação de uma atmosfera de suavidade, o leitor é colocado dentro do mosteiro: "Aqui”.

Ainda no mesmo ato, quando surge Carlos V, a digressão histórica retorna à cena:

Carlos V de Alemania y I de España viene vestido con un traje pardo de viaje y se asemeja mucho a sus mejores retratos. Es ya el padre de la cristiandad por encima de Clemente VII; el señor del mundo por encima de Francisco I y de Enrique VII; lúcido, preciso, guerrero pacifista. Sin estas condiciones suyas, quizás el protestantismo no hubiera llegado a afirmarse en Europa. Es, además, el padre de la Nueva España, pero también del padre, por su nacimiento, de la 
Inquisición española, y, sobre todo, el hijo de Juana la Loca. Es ya, en el haz de auroras de este momento del mundo, el hombre a quien el exceso de poder llevará, treinta años más tarde, a la abdicación, para gozar también de la última posesión posible de la tierra: la renunciación. Su mente está ya formada para moverse y funcionar; en un constante juego de luz y sombra en una dualidad constante: flamenco, alemán y español; guerra y paz, religión y lucha con Roma; lucha contra y tolerancia de Lutero; heroísmo militar y misticismo dualidad de la que Felipe II no heredará sino el cuadrante de sombra a las agujas de la sospecha y de la duda. Acaba de ganar otra batalla a Francisco de Francia ya que se apresta a recibir la corona de los romanos: pero su ánimo y sus ideas están en otra, misteriosa parte. (TC II, p. 845-846).

Inicialmente, ganha ênfase o advérbio “já”. Ele assinala que o momento dos fatos a serem representados é posterior às lutas do rei. A seguir, as informações sobre as conquistas passadas se somam às das futuras. Essa condensação temporal, realizada quase na mesma frase, amalgama uma visão histórica completa do evento. Em outras palavras, a condensação proporciona que o leitor perceba a existência de uma construção narrativa que dá sentido aos eventos no tempo (RICOEUR, 1994). Forma-se, a partir desses avanços e antecipações, a ideia de um acontecimento histórico no sentido mais tradicional desse conceito. (VEYNE, 1995 e CERTEAU, 1982).

Após recriar uma atmosfera histórica da ação que será mostrada, a voz didascálica prossegue assemelhando-se a procedimentos narrativos. Surgem expressões cuja construção frásica ganha dinamismo quase poético ao passar do "constante juego de luz y sombra” para o "heroísmo militar y misticismo" representados pela personagem em foco.

Mais um recurso típico da prosa romanesca, a peripécia, isto é, a quebra do desenrolar de uma ação ou episódio para anunciar que algo contrário está para acontecer, também é utilizado no trecho acima. No caso, o efeito de expectativa está marcado pela conjunção adversativa e, ao final, pelo adjetivo: "pero su ánimo y sus ideas están en otra, misteriosa parte."

Ainda nessa mesma peça, o segundo ato traz outros procedimentos. Entram em cena, pouco a pouco, os padres convocados pelo arcebispo Juan de Zumárraga. O primeiro é Toribio de Benavente, ou Motolinía:

[...] entra por la izquierda un fraile que, debiendo llevar hábito pardo, lo lleva azul como todos sus hermanos de Orden a causa de faltar la tela parda en Nueva España, según parece. Hombre delgado y ascético de facciones bondadosas y aire fatigado. Se dirige a Martincillo, que 
lo contiene y lo invita con el mismo ademán de escuhar [o que o arcebispo Zumárraga diz aos alfaiates que o visitam] (TCII, p. 868).

Nada nessa didascália anuncia quem chega. O leitor tem acesso a essa informação depois de algumas outras falas: "Una pausa. Fray Toribio de Benavente llamado por los indios Motolinía o El Pobrecito, sonríe y se dirige hacia un sillón de cuero en el que se instala con un suspiro de alivio.” (TC II, 869). A apresentação compartimentada dessa personagem é responsável por criar na leitura, à maneira de prosa, o efeito de suspense. Colaboram ainda recursos como o uso do artigo indefinido (um frade) para introduzir o tópico do texto e a consequente determinação, "homem magro e ascético". Nenhuma delas, porém, é suficiente para romper a expectativa, tal como se espera de uma didascália, conceitual e convencionalmente falando.

O próximo padre a chegar para a reunião é Bartolomé de Las Casas. A forma de introdução dessa personagem é, digamos, similar (para não dizer igual):

Durante esta frase de Motolinía habrá entrado sin ser visto, deteniéndose en el umbral, un fraile dominico, con la figura llena de autoridad, gallardía y española cólera, siempre en estado de ebullición. En este hombre la bondad misma, que es el índice de su carácter, reviste un vigor y una fortaleza extraordinarios: es el prior Las Casas. (TCII, 869).

Novamente, nos deparamos com a indeterminação da personagem ("um frade dominicano") e a aproximação ("este homem"), até que surge como uma persona ("o prior Las Casas").

\subsection{As estruturas narrativas da rubrica e a concepção cênica de uma época}

A partir da análise dos tópicos precedentes identificamos, em síntese, que as escolhas ligadas a estruturas narrativas dentro das didascália são comuns em Usigli, constantes em Leñero e raras em Sabina Berman. Elas funcionam como índices não apenas de um estilo próprio, mas podemos afirmar que se trata de um fenômeno da sociologia do gênero no sistema dramatúrgico mexicano.

O caso de Leñero é ilustrativo, porque ele faz a intermediação de uma etapa a outra do processo de transformação e aglutinação de autores e obras. O fato dele utilizar esse tipo de técnica desde a primeira peça, tendo-as herdado ou não do trabalho de repórter, contista ou romancista, faz parte de seu estilo. Devemos reconhecer ainda que, 
a despeito dele ter incorporado com modificações os preceitos de Piscator, Weiss e Brecht, a narração é uma marca peculiar e já praticada por conterrâneos precedentes. Porém, diferentemente de Usigli, que acreditava na concepção segundo a qual o autor é o responsável total da obra, Leñero reconhece o papel dos demais profissionais envolvidos. Nesse sentido, vale lembrar que ele inicia sua trajetória de dramaturgo num período em que a dicotomia entre teatro de autor e teatro de diretor já era uma força atuante no sistema teatral mexicano. A elaboração mais refinada da literatura dramática seria, neste sentido, uma maneira de se legitimar dentro das novas formas de produção teatral.

Além disso, o contexto dos anos 1970 tomava a criação teatral como espetáculo, não apenas no México. Isso significa que os longos diálogos foram sendo paulatinamente substituídos pela performance, pela movimentação e pela gestualidade. Nesse novo cenário, mais uma vez, a exploração da didascália se oferecia como um espaço singular para potencializar a linguagem literária.

O teatro de Sabina Berman nasce já dentro dessa nova concepção. Discípula de Hugo Argüelles na escrita e de Abraham Oceransky na concepção cênica, muitos de seus espectáculos são construídos em conjunto com os atores durante os ensaios. A despeito de trabalhar a voz didascálica com um pouco mais de esmero até 1985, há que se ressaltar sua clareza acerca do funcionamento do palco quando harmoniza diálogos e movimentação. Isso reduz ao mínimo o uso de rubricas elaboradas.

Já os dramas usiglianos, como vimos, lançam mão de longas didascálias, provocando diversos efeitos de sentido. Como, em sua perspectiva, tratava-se de uma arte sem tradição, não recorreu a modelos ${ }^{146}$. Preferiu prescindir, por exemplo, dos experimentos que o Teatro de Ulises e o de Ahora realizaram com técnicas mais afinadas com o que se produzia nos centros hegemônicos. Assim, para criar a tradição que ele queria iniciar, buscou também na história e na historiografia os fundamentos textuais de seu teatro.

\footnotetext{
${ }^{146}$ Estamos cientes de que George Bernard Shaw é amplamente citado por Usigli, que em um de seus ensaios menciona que estava sendo criticado por isso. Não se pode falar, porém, que o dramaturgo irlandês tenha exercido "influência" nem que fosse seu "modelo".
} 


\section{Capítulo 7 - Representações da Conquista do México}

Este capítulo busca analisar a refiguração da Conquista do México nos três dramaturgos selecionados. Embora eles tenham escrito sobre a Revolução mexicana ${ }^{147}$, o evento do século XVI se vincula mais diretamente às formas de constituição identitária porque pode ser considerado trauma coletivo. Assim, sua reelaboração constante em vários âmbitos da cultura, em especial no teatro, reflete a profundidade das cicatrizes de um acontecimento que, historicamente, seria o ponto de partida de entrechoques culturais, econômicos, políticos e temporais. ${ }^{148}$

As obras analisadas aqui são Corona de fuego de Rodolfo Usigli (1963/1979); Águila o sol de Sabina Berman (1984/1985); e por fim, La noche de Hernán Cortés de Vicente Leñero (1992/2008).

\subsection{A Conquista em três momentos}

A partir do título, Corona de fuego representa a tensão desencadeada no processo de Conquista. O fogo acentua a luta, pois carrega sentidos simbolicamente diferentes para as culturas envolvidas no evento histórico. Para os cristãos, que são um dos pólos da tensão, ele pode figurar tanto a condenação quanto a purificação da alma. Já para o lado asteca, condensado na figura de Cuauhtémoc II, esse elemento natural está carregado de negatividade. Na Visão dos vencidos ele é evocado logo nos presságios do

\footnotetext{
${ }^{147}$ Como sabemos, o fato é abordado por Usigli em El gesticulador, que sublinha as consequências do movimento poucos anos depois de encerrado. Sabina Berman, em Entre Villa y una mujer desnuda, também foca os efeitos, mas na contemporaneidade. Leñero centralizou as preocupações no assassinato do presidente Álvaro Obregón em El juicio (1972 / TC I). No entanto, apenas neste último está esboçada a tentativa de ambientar a ação em um tempo anterior ao da representação enunciada. Uma vez que na "escala" de objetivos nossa pesquisa privilegia a representação do passado para a posteriori verificar as implicações desse procedimento no presente, a Conquista é o fato histórico mais propício a comparações.

148 Para reforçar a importância da Conquista para o teatro, gostaríamos de mencionar outros autores e obras. Sergio Magaña escreveu Moctezuma II, em 1954. Celestino Gorostiza, em 1958, La leña está verde o La Malinche. Luisa Josefina Hernández (Quezalcóatl, 1968), Hugo Argüelles (El Gran Inquisidor, 1971) e Salvador Novo (Cuauhtémoc, 1962) estão entre os autores próximos a Usigli que, nos anos 60, recriaram o episódio. Em 1970, Carlos Fuentes se aventurou no teatro com Todos los gatos son pardos. Além dessas obras, recordamos que Malinche é a protagonista de várias outras, tais como Malinche Show, de Willebaldo López e El sueño de la Malinche, de Marcela del Río. Finalmente, Emilio Carballido, estabelecendo uma ponte entre um período de efervescência e outro de recuperação do tema, escreveu Tiempo de ladrones: La Historia de Chucho el roto (1983) y Ceremonia en el tiempo del tigre (1986). No final dos anos 80, Mauricio Jiménez recebeu uma bolsa do Consejo Nacional para la Cultura y las Artes para criar e montar Lo que cala son los filos e, no início de 1990, Arturo Sastré escreveu e dirigiu (também sob bolsa CONALCULTA) Casa de comedias.
} 
Códice Florentino: "Dez anos antes de virem os espanhóis apareceu um agouro no céu. Algo como uma espiga de fogo, como uma chama de fogo" (LEON PORTILLA, 1987, p. 26).

A oposição reaparece no quadro reelaborado por Berman em Águila o sol. Título que é uma expressão corrente, cujo significado orbita ao redor de elementos populares e evoca inicialmente as imagens cunhadas nas faces das moedas mexicanas. Assim, ela se refere ao jogo de "cara ou coroa", em que o papel do destino, da sorte e do azar, do risco e da expectativa estão em jogo.

O sentido de luta se expande por meio de imagens que simbolizam os antípodas das forças que lideraram as batalhas no momento da conquista do território indígena. A águia, símbolo nacional cunhado também na bandeira, representa Cuauhtémoc II, o último imperador mexica, "a águia que pousa”, que seria a "salvação", caso o deus-serpente Quezalcóatl voltasse. ${ }^{149}$ Essa volta, aliás, é dada como certa quando Moctezuma tem notícia da chegada de homens brancos pelo mar. Já o sol do díptico evoca o próprio Cortés e a Coroa espanhola do período de Carlos I de Espanha e V de Alemanha. Portanto, os astecas, no processo da conquista, sentiram-se entre a águia e o sol, ambos prejudiciais. A expressão carrega o sentido de condenação, pois as opções ofereceriam tristes destinos.

Em La noche de Hernán Cortés, Leñero desloca sutilmente as luzes para uma das personagens mais instigantes de todo o processo da Conquista: o capitão que entrou em Tenochtitlan e subjugou o exército de Moctezuma. A "noite" em que vive este Hernán Cortés serve não apenas para compor a unidade temporal da ação dramática; ela evoca também o momento e o espaço da imersão nos pensamentos. Da "noite" se depreendem o sono e o sonho, relacionados com o afloramento do inconsciente. Nesse sentido, ela anuncia a possibilidade de exploração dos desejos, incertezas, dúvidas e recordações. O título ainda propõe um jogo discursivo com o episódio que a historiografia denominou de "noite triste". Nele, as tropas do conquistador teriam perdido uma das batalhas na tomada de Tenochtitlan. ${ }^{150}$

\footnotetext{
${ }^{149}$ Esse imperador recebera o trono havia cerca de um ano após a morte de Moctezuma Antes dele, o irmão de Moctezuma, Cuahtli, assumiu o cargo, mas não teve vida longa.

150 “A noite triste" é um episódio que narra o retorno de Hernán Cortés à capital asteca depois de ter vencido Pánfilo de Narváez, capitão enviado pelo governador de Cuba para impedir o avanço do conquistador. A "noite" é "triste" para os espanhóis, pois nela acontece a desforra dos indígenas. A vingança fora engendrada porque Pedro de Alvarado, que Cortés havia deixado responsável enquanto fora lutar contra Narváez, atacara os astecas durante a festa de Tóxcatl, em louvor ao deus Huitzilopochtli. O alçamento indígena ocorre depois da matança no Templo Mayor e a prisão de Moctezuma. A batalha dura quatro dias. O tlatoani teria sido morto ao fim desse período.
} 
Como se percebe, a trama e a concepção histórica de cada obra sublinham diferentes aspectos de um mesmo processo histórico. As duas primeiras procuram abordar o tema a partir de uma visão coletiva, mesmo que na primeira sobressaia a figura de Cuauhtémoc. Aspecto importante, porque se enfatiza a luta e o choque cultural de maneira distanciada, mostrada sob várias óticas. Por outro lado, em La noche de Hernán Cortés, os episódios aparecem sob uma perspectiva subjetiva, motivados pelas "escolhas" que o protagonista faz ao recordar algum acontecimento.

As implicações interpretativas que os títulos propõem somam-se às maneiras de organização da expressão estética. Corona de fuego, que traz o subtítulo de "Primer esquema para una tragedia antihistórica americana", tenta recriar um gênero marcado por regras rígidas. A fim de dar unidade de tempo, concentra a ação entre 27 e 28 de fevereiro de 1525, os últimos dias de Cuauhtémoc, quatro anos depois da queda de MéxicoTenochtitlan.

No primeiro ato, intitulado "La llegada", entra a comitiva liderada pelo conquistador para buscar dois espanhóis, Cristóbal Olid, ex-capitão da tropa, e Pedro de Alvarado, ambos considerados traidores depois que o governador de Cuba, Diego Velázquez, os enviou a Hibueras (Honduras) para tomar posse da região. O grupo é composto pelos franciscanos Juan de Aora, Juan de Tecto e Juan Varillas, o governador interino da Nova Espanha Gonzalo de Salazar, o navegador Juan de Velázquez, Andrés de Tapia, ${ }^{151}$ a "língua" Doña Marina e, por fim, Bernal Díaz del Castillo, cujo papel de cronista se sobrepõe aqui ao de soldado. Apesar de não haver indicação nas didascálias, infere-se a presença do prisioneiro Cuauhtémoc.

A comitiva chega a Tuxakhá, região sob o domínio maia onde reina o cacique Pax Bolón Acha. Cortés é recebido por Paxua, seu filho, que lhe conta sub-repticiamente que o pai está morto. O encontro parece marcado por boas-vontades, pois há inclusive troca de presentes. Não obstante, por trás da atmosfera amistosa, esconde-se a verdade sobre a morte do chefe indígena.

O líder espanhol fica sabendo, "en secreto", pelo cacique de Tizátepetl, “que Pax Bolón reina aún en la tierra" (USIGLI, TCII, p. 786). A seguir, ainda no primeiro

\footnotetext{
${ }^{151}$ Esses nomes não se referem a Juan de Velázquez, primo do governador de Cuba, e Andrés de Tapia, capitão e cronista, ambos participantes da expedição cortesiana contra Pánfilo de Narváez. Na verdade, são os nomes cristãos recebidos pelos sucessores de Cuauhtémoc, os quais foram designados por Cortés a morte deste último. Juan Velázquez Tlacotzin foi o $12^{\circ}$ tlatoani, o primeiro nomeado pelo conquistador após a execução de Cuauhtémoc. Ficou apenas um ano no cargo, pois faleceu. Andrés de Tapia Motelchiuhtzin foi seu sucessor, também nomeado por Cortés, e "governou" de 1526 a 1530. Eles haviam sido presos e torturados com Cuauhtémoc, mas ao contrário dele, cederam aos espanhóis.
} 
ato, Cortés cobra explicações de Paxua sobre a mentira. Sem saber exatamente como o conquistador soubera da verdade, o príncipe atribui a descoberta à sua capacidade de guerreiro. Por isso, explica ao pai que os brancos "son [como] dioses y lo saben todo." (USIGLI, TCII, p. 790).

Quando Cortés e o rei dos chontales se veem frente a frente, este último revela a mentira e, ao mesmo tempo, procura dissuadir o espanhol:

Señor, señor de los dioses enviado
y amado de los dioses y los indios,
yo no quise engañarte, yo quería
saber tu voluntad para servirte,
y quería para mis ojos solos
el privilegio de mirar el sol.
Deseaba verte, mas tuve temor
por no conocerte, señor.

Imediatamente, oferece lugar de descanso, comida e mulheres: "te pido que me mandes y me pidas, / lo que quieras en bienes, joyas y en doncellas" (TCII, p. 793).

Armado o conflito, no segundo ato são representadas sucessivamente as festas indígena e espanhola. Nesse contexto de alegria, mostram-se novas articulações políticas contra Cortés. Pax Bolón incita Cuauhtémoc a se insurgir. No entanto, suas palavras a princípio carecem de clareza:

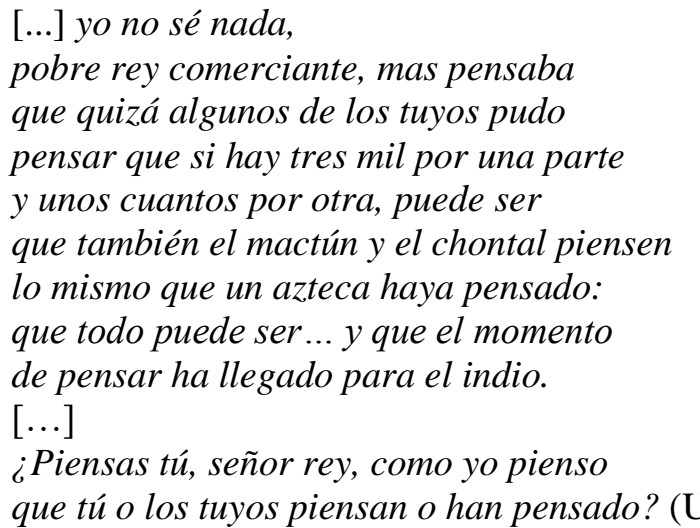

Antes de começar efetivamente a festa indígena, com danças, cantos, instrumentos etc., na cena dois do segundo ato Cuauhtémoc se aconselha com "sus grandes", Tetlepanquetzin, Coanacoch e Temilotzin acerca da repartição dos reinos, pois por fazerem parte da comitiva de Cortés, estão juntos na conquista de outros povos. As regras da repartição são pensadas a partir de antigos princípios da organização política daquelas nações. Coanacoch, por exemplo, diz a Tetlepanquetzin: 
¿Es cierto acaso o no, que la ciudad de Texcoco y mis reinos chichimecas tienen la preferencia de todo, según leyes concertadas entre Netzahualcóyotl, el abuelo poeta, y tlacatecuhtli Itzcóatl, tu glorioso antepasado?

Contudo, Cuauhtémoc sabe que esses critérios já não servem mais:

No, eso es ir muy atrás, Coanacoch,
volver a tiempos viejos en que nuestros ejércitos
iban solos y se tomaba en cuenta
que era Texcoco nuestra antigua patria,
que de ella proceden nuestra estirpe y linaje.
Pero los tiempos cambian. Ya no estamos
los aztecas tan solos [...] (USIGLI, TCII, p. 804).

A conversa entre os chefes indígenas prossegue durante a festa e é acompanhada por Mexicaltzinco, "un enanito únicamente cuyas pantorrillas eran en forma de bola", conforme indica a didascália inicial (TC II, p. 775). Esse "anãozinho", durante a reunião dos conselheiros, fica presente "limitando su actuación a escuchar y cambiar rítmicamente de postura y de área escénica, a veces de frente, a veces de espalda al público” (TCII, p. 808).

A festa, então, é interrompida por Doña Marina, que transmite ordens de Cortés para encerrá-la, pois o barulho atrapalha os pensamentos do capitão e aquela postura não confere nobreza aos reis. Nesse momento, a mulher é uma porta-voz das vontades do capitão espanhol. A função de intérprete pela qual ficou conhecida na história está subentendida pela explicação das "regras" culturais do grupo mesoamericano.

Tendo sido interrompido em ações típicas de sua cultura, as palavras de Pax Bolón ao imperador asteca deixam de ser cifradas:

Yo soy de parecer, si tú lo eres, que los matemos. Pero ¿qué podría hacer yo solo, que no sé de guerras, sin tu gloria y tu fuerza y tu grandeza?

Tú traes mucha gente; nosotros somos muchos.

Piensa, señor Cuauhtémoc, piensa ipiensa!

Ao que o imperador contesta:

Veré en todo ello, Pax Bolón.

Déjame tiempo de reflexionar, hablaremos mañana, en otra aurora. (USIGLI, TCII, p. 813). 
Mexicaltzinco ouve esse diálogo e "delata” os interlocutores a Doña Marina. Em um jogo de gestos repetidos, Don Hernando ouve, de fora da cena, as delações do anão e, já no palco, recebe de Tapia e Juan de Velázquez novas imputações contra Cuauhtémoc. “Tapia — ¿¿Cuánto tiempo para que los aniquilemos’? / dijeron” (USIGLI, TCII, p. 815). Essas acusações, que também são invencionices, são acrescidas às de Pax Bolón que, em uma audiência com Cortés, revela um suposto plano do imperador asteca contra os espanhóis.

Nessa alternância de falas ardilosas, a recriação ficcional do episódio histórico se mostra, assim como em El gesticulador, menos interessada na verdade do que no próprio ato criativo. A rigor, o chefe chontal expressa vontade de matar os espanhóis e de possuir reinos conquistados junto com eles, mas não se ouve da parte daqueles que seriam cúmplices nenhuma confirmação da proposta. Dessa forma, fica patente que a sobreposição de mentiras, mais do que revelar uma suposta verdade dos fatos, põe em marcha estratégias teatrais de espelhamento, suspense, ficcionalidade e talvez até de metateatralidade.

Se na visão de Usigli os últimos dias de Cuauhtémoc sintetizam toda a Conquista, na ótica de Berman um episódio anterior, a morte de Moctezuma, serve para simbolizar o evento. Para além dos significados que ele poderia assumir através da reescrita, a ficcionalidade é a que mais se enriquece.

A ação, muito menos concentrada, transcorre desde os primeiros agouros percebidos pelos astecas sobre a chegada de Hernán Cortês (quando ainda havia a interpretação de que se tratava da volta de Quetzalcóatl) até a recepção do capitão espanhol, seguida do assassinato de Moctezuma e da conquista do Império asteca. Faz parte desse processo aqui também a "noite triste".

Águila o sol possui muitas personagens, de modo que é difícil se falar em protagonistas. No entanto, Malinche, Cortés e Moctezuma ocupam lugar de destaque, até mesmo porque são algumas das poucas nomeadas. No geral, os caracteres compõem um quadro social ou têm função metateatral: Soldado, Enviados (de Moctezuma), Cholultecas, Bêbado, Mago, Índio; Ator, Cômico, Espectador, Vozes 1, 2 e 3 etc.

No tocante às ações, os acontecimentos estão divididos em quinze quadros; todos com títulos ${ }^{152}$ praticamente retirados dos 14 capítulos da Visão dos vencidos, de

\footnotetext{
152 "Los presagios", "Noticia cierta", "El encuentro", "Se acaba el mundo entre prodigios", "Días funestos", "Teatro Callejero", "Patlahuatzin", "La masacre de Cholula", "Tezcatlipoca", "Bautismos", "Los ojos de Cortés en los ojos de Moctezuma", "El tesoro", "Huitzilopotli”, "Moctezuma" e "La Llorona".
} 
León Portilla. Essa divisão marca momentos centrais do evento histórico (os presságios sobre a chegada de Cortés, o massacre de Cholula e o encontro do chefe espanhol com o tlatoani asteca). Além disso, reforça aspectos do imaginário cultural através, por exemplo, da personagem folclórica conhecida como Llorona. Outros títulos encabeçam episódios secundários, tais como o da festa a Huitzilopotli, deus superior da cosmogonia asteca; o batismo de Fernando de Alva Ixtlixuchtli, príncipe de Texcoco que viveu de 1500 a 1559; e a violência contra o príncipe tlaxcalteca Patlahuatzin, cujos braços foram cortados pelos cholultecas quando, enviado pelo avô, instigava-os a se render aos espanhóis.

No último quadro acontece o desfecho da história. Moctezuma morre, em decúbito frontal, sobre um "banquinho" expressando ao público seu último lamento: "Que ellos eran trescientos y nosotros millones." (BERMAN, 1985, p. 265).

A peça de Leñero também está dividida em quadros, que correspondem aos lugares e tempos onde se desenvolvem as ações. Obedecendo à ordem da didascália preliminar, o primeiro é Sevilha, em 1547 - ou em $1990 .{ }^{153}$ O segundo é Coyoacán, em 1522. A seguir, Cempoala, 1519. E, por fim, Cuba, 1514. Observamos, portanto, um movimento de retrocesso cronológico na sequência dos quadros.

Essa movimentação das personagens pelos quadros acontece na medida do desejo de Hernán Cortés. Sua vontade de regressar aos lugares que recorda dá unidade à ação, apesar do aperspectivismo provocado pelas passagens de um a outro cenário. As transições implicam alterações no perfil e na caracterização de Hernán Cortés, pois constituem etapas diferentes de sua vida. Entretanto, a reminiscência não incide em quantidade proporcional. Sevilha, o espaço mais atual, aparece cinco vezes. Coyoacán, quatro; e Cempoala e Cuba, onde se localiza o passado mais remoto, duas cada uma. As personagens se movimentam constantemente de um a outro ambiente e tempo.

Muitas personagens perpassam esses espaço-tempos, mas apenas três "poseen una identidad única": o próprio Cortés, o Secretário (designado de maneira alternada por Francisco López de Gómara, Bernal Díaz del Castillo e Francisco Fernández y Pereyra) ${ }^{154}$ e o Anão que os acompanha. Os demais personagens (Malintzin, Diego de Velázquez, Catalina Suárez, o Cacique Gordo de Cempoala etc.) "forman parte de los 'Fantasmas de Cortés"”. (LEÑERO, TC II, p. 425).

\footnotetext{
${ }^{153}$ No capítulo anterior, desenvolvemos com mais vagar uma análise das implicações cênicas dessa forma de apresentar o tempo e o espaço em Leñero.

${ }^{154}$ Apesar da alternância, verificamos uma interessante simetria na quantidade de vezes que cada um aparece. Se contados os vocativos durante uma sequência dialógica, encontramos em torno de 7 a 9 nove vezes a evocação dos cronistas.
} 
No desenrolar das ações, ganha destaque o espaço-tempo de Cempoala (que, como vimos, aparece somente em duas oportunidades), caracterizado cenograficamente por uma pirâmide sobre a qual estão colocados dois ídolos gêmeos. A relevância desse lugar para a história da Conquista se deve ao fato de ter sido, segundo as palavras do cronista Bernal Díaz del Castillo (1977, p. 161), "la primera entrada que hizo Cortés en la Nueva España”. A passagem da comitiva espanhola por aquelas terras teria ocorrido uma única vez antes do encontro do capitão com Moctezuma. Na peça, apesar de ser o quadro de menor extensão, é constantemente referenciado, pois a todo instante as didascálias indicam que o Cacique Gordo e Malintzin, personagens ambientadas ali, observam os demais espaço-tempos e seus actantes.

Assim, a primeira movimentação mostra Cortés relembrando alegre e epicamente a conquista do povo daquela região. Em cena, os espanhóis enfrentam os indígenas. Um dos ídolos é derrubado e, por fim, a cidade é tomada. A seguir, Cortés manda o Secretário registrar tudo, para que nada se perca: "ni el gesto maricón del Cacique Gordo ni los aspavientos de ese asqueroso monigote sacacorazones..." (LEÑERO, TCII, p. 455). O desfecho dessa ação vivida por Cortés com soberba e satisfação é o estupro de Malintzin.

Lembrar a "grandeza" do episódio, porém, não satisfaz a memória do Cortés atual. Ele pretende reviver aquele momento e, por isso, volta a Cempoala. Como havia derrubado apenas um dos ídolos, questiona a possibilidade de lançar também o outro pelas escadarias da pirâmide. E procura fazê-lo. No regresso, velhos fatos são reproduzidos e novos acontecem. Oscilando entre a dúvida, a demência e a velhacaria, ele pergunta ao Secretário: “ ¿Por qué no derribé el otro? (Se atemoriza) ¿O es que no derribé ninguno?” (LEÑERO, TCII, p. 472). Embora o Secretário confirme o fato e diga que há testemunhas, o capitão continua manifestando seu desejo de revivê-lo: “ ¿Pudo ser diferente, Bernal?”. Por fim, decide por reproduzir o gesto pretérito. Dessa vez, no entanto, é atacado pelos guerreiros daquele povo e pela própria Malintzin. Nesse ponto acontece a morte simbólica de Cortés. A índia que estuprara finca-lhe, com ódio, uma lança no peito.

O capitão, assim como no primeiro quadro de Cempoala, ordena que o Secretário registre o acontecimento. Ele o faz em termos notariais, mas em completa divergência com o que se conhece hoje sobre o evento:

SECRETARIO: Esto fue lo que ocurrió. (Gime. Con voz cortada.) El 23 de junio del año de 1519, el capitán don Hernando de Cortés, que enviado por el gobernador de Cuba, don Diego de Velázquez, había 
desembarcado en Cozumel con once navíos, quinientos ocho soldados, cien marinos y dieciséis caballos para descubrir nuevas tierras, fue muerto por heridas de flechas y lanza durante una feroz batalla en un pueblo llamado de Cempoal. (LEÑERO, TCII, p. 474).

A seguir, o Secretário e o Anão recolhem o conquistador e o levam para Sevilha, onde morre definitivamente insistindo em dizer que a destruição dos ídolos foi uma grande façanha.

Como podemos perceber, cada autor acentua estágios diferentes dos contatos iniciais entre indígenas e espanhóis. É relevante observar que quanto mais próximo está o dramaturgo do período histórico maior é a ênfase em um episódio representativo dos últimos dias da Conquista. Usigli, que produziu em um período eminentemente nacionalista, elabora a morte de Cuauhtémoc. Leñero, nos anos em que a ressignificação da identidade, da história e da nação era mais importante do que a estima por essas categorias, retrata a chegada a Cempoala, talvez o acontecimento mais remoto do entrechoque. Berman, por sua vez, recria a morte de Moctezuma, episódio altamente emblemático de todo o processo porque centraliza a transição de uma etapa a outra no desenrolar do conflito. Essas escolhas, a despeito da aleatoriedade ou coincidência que possam ter, correspondem aos sentimentos de construção e ressignificação nacionalista em cada fase do século XX a que pertencem cada um dos três dramaturgos.

\subsection{Montagem e concepção cênica}

Recuperando a assertiva de Armando Partida Tayzan (2002b), para quem na metade do século $\mathrm{XX}$ teria ocorrido um corte na dramaturgia mexicana cuja principal mudança foi a passagem para uma concepção dramática teatral não-aristotélica, observamos que as peças sob análise neste capítulo condizem com esse pressuposto. A partir disso, podemos investigar quais condições de produção teriam propiciado as alterações, considerando-se os procedimentos técnicos mostram essa passagem.

No caso de Corona de fuego, o fato de ser uma tragédia sinalizaria, entre outros aspectos, seu intuito de provocar a catarse. Esse propósito estético estaria em sintonia com os princípios éticos das vozes nacionalistas dos anos pós-revolucionários. Apesar da concepção clássica, desde a primeira montagem discute-se o alcance de sua tragicidade 
Quando da sua escrita e montagem, Usigli já era um escritor e intelectual de respeito no meio teatral. Fama essa que recolhera em grande medida pela habilidade em criar polêmicas e denunciar vícios da vida social e cultural mexicana. Com essa peça não foi diferente. Volek (1996) e Beardsell (2002) afirmam que Corona de fuego, desde a estreia em 15 de setembro de 1961, está entre os maiores fracassos de toda a carreira de Usigli. ${ }^{155}$ As "falhas" adviriam, por exemplo, do uso do verso, que muitas vezes perde ritmo, métrica e rima; da prolixidade dos diálogos; da dificuldade de manter a tensão dramática por causa da extensão das falas; do apego à historiografia. "Nada de gracia se encuentra en los 'dos mil cuatrocientos diez versos', bastante trabajosos; ni en los interminables coros de los españoles y de los mexicanos, que aumentan la inmovilidad de la inacción." (VOLEK, p.261). ${ }^{156}$

Contrariando essas opiniões, Armando de María y Campos escreveu, no calor da hora, duas críticas positivas sobre a montagem. Na primeira, publicada na revista Novedades e que data do mesmo dia da estreia, ele lembrava que Usigli voltava à cena após um longo período ausente dos palcos mexicanos e que a representação, classificada de "deslumbrante" pelo crítico, tinha estreado diante de um público de grande valia para a vida social e cultural do DF. Trata-se, como se vê, de informações importantes, mas que não chegam a ter profundidade interpretativa.

A segunda crítica, publicada na mesma revista em 27 de setembro, elogia a "audácia" (a palavra aparece duas vezes na resenha) e a magnificência do autor. Para o final, destacava positivamente a direção de Retes, que teria conseguido imprimir movimento à ação, mesmo a peça sendo estática. Apesar dos elogios, a falta de movimentação lhe parecia um aspecto negativo e ressaltava a dificuldade que isso significava para o espectador:

Nadie pone en duda, y buena prueba de ello es Corona de fuego, la calidad de Usigli para componer, o si se quiere, crear, el teatro como le da su talentosa gana. Pero no siempre su teatro es un teatro fácil o accesible. Y Corona de fuego es otra elocuente prueba de su meditado antiteatralismo. (DE MARÍA Y CAMPOS, 1961)

\footnotetext{
${ }^{155}$ A direção foi de Ignacio Retes, cenografia de Julio Prieto e música de Luis Sandi.

${ }^{156} \mathrm{Na}$ peça existem trechos de matéria épica que parecem entrar em conflito com a pretensão trágica. A escolha dos títulos para cada um dos atos reforça essa observação. Ao mesmo tempo, é interessante notar que a capitulação dos atos não indica que eles devam ser mostrados ao público.
} 
A ideia de que além de anti-histórica, a peça fosse também antiteatral, aparece novamente no fim do texto e a dubiedade da opinião geral pode ser entrevista já no título dessa segunda resenha, "Corona de fuego, discutida pieza de Rodolfo Usigli. II", que demonstra o questionamento da qualidade da obra logo na primeira montagem. A questão parece ter sido tão forte que o próprio Usigli tentou se defender no ensaio que acrescentou à publicação do terceiro volume de seu Teatro Completo. Chamado "Notas a 'Corona de fuego"” (TC III, p. 791- 819), o texto inicia-se assim:

Ante la a todas luces no meditada ofensiva de un sector de la crítica capitalina, y en respuesta a preguntas de personas interesadas y serias, aunque abrigaba la firme intención de guardar silencio en este caso, me decido a publicar algunas notas preparatorias a Corona de fuego.

Sua defesa, como sempre, é contundente. O dramaturgo não permite espaço para críticas negativas e, em muitos momentos, seus ensaios de defesa são mais eficazes do que as obras. As discussões estão pautadas por um preceito crítico que buscava julgar a capacidade do autor de atender a determinadas regras de um gênero, no caso, a tragédia.

Analisando a questão à luz dos conceitos de "morte da tragédia” (STEINER, 1991) e de "tragédia moderna" (WILLIAMS, 2002) novos caminhos podem ser propostos. Embora sejam operadores que se contrapõem, eles ajudam a perceber que o contexto de avanço modernizador no México à época em que a peça foi montada pode ser o primeiro indício de que se tratava de uma criação anacrônica. Nesse sentido, então, devemos reconhecer que, dentro desse contexto, a própria representação da morte de Cuauhtémoc apresenta uma dificuldade ímpar. Além disso, a ênfase no destino do imperador conforme afirmamos no tópico anterior - impossibilita o trágico, porquanto sua queda, tratada como injustiça, não nos é mostrada. Quando surge pela primeira vez em cena ele já está sob o jugo de Hernán Cortés. Não existe luta contra a situação que está para ocorrer. Portanto, sem o desvelamento da passagem da condição elevada do personagem em direção à sua queda, e sem passar pela hybris, não se dá o impacto catártico.

E, no entanto, independentemente dessas questões, não se pode negar que nas didascálias se confirma a opinião de María y Campos sobre o conhecimento que o autor possuía tanto das questões de viés literário quanto daquelas que dizem respeito à encenação propriamente dita. Emblemático é o uso da luz e da música. Na abertura, sombras projetadas na parede indicam a sensação do cansaço dos personagens gerado pela jornada de Tenochtitlan a Hibueras. As sombras são acompanhadas de sons 
instrumentais representativos das culturas europeia e indígena, conforme os Coros de Espanhóis ou de Indígenas ocupem o primeiro plano da movimentação.

No que tange às questões do diálogo, vemos que em diversos momentos as falas buscam criar a atmosfera de uma cena, embora, de tão extensas, acabem servindo mais para declamação do que para execução de ações. Porém, Usigli também se preocupou com isso: "Conviene estudiar la posibilidad de fragmentar los coros de modo que los recitantes respectivos puedan alternarse en la declamación de pasajes simétricos. (De igual o parecido número de versos.)" (USIGLI, TC II, p. 776).

Situação diferente foi a de Sabina Berman na estreia de Águila o sol. Escrita no começo dos anos 80 (por volta de 1982), a peça visava a compor o rol de obras que o INBA apoiava para serem montadas pela Companhia de Teatro Nacional. Embora não tivesse aceitação imediata, graças à insistência do diretor Abraham Oceransky, passou a integrar o conjunto de peças que deveriam ser apresentadas no interior do país, principalmente em escolas. São pouquíssimos os recursos cênicos da montagem, conforme indicam as didascálias e algumas notas da edição que utilizamos. O motivo desse enxugamento parece ter sido as longas viagens e a falta de espaços teatrais apropriados nos lugares de apresentação da peça. Um exemplo é o quadro "El encuentro". Nele, os enviados de Moctezuma se deparam com Cortés. Pela rubrica, somos avisados que "en la nave española, en cubierta, [estão] La Malinche y un soldado español." A nau era representada por um pequeno palco e a canoa em que estariam os indígenas deveria ser marcada apenas pela gestualidade "con dos palos movidos como remos". (1985, p. 234).

Por esses anos, a autora era uma estreante. Não obstante já possuísse publicações e montagens, apenas começava uma carreira. Mesmo assim, chegaria aos teatros da capital, sob direção de Oceransky. Por meio de uma crítica de Rafael Solana publicada em 22 de maio de 1985 no jornal Siempre, sabemos que houve uma curta temporada no Foro Isabelino, durava menos de uma hora e estava sob a direção de Oceransky. Sem maiores discussões acerca da recepção, o crítico destaca as facilidades de mobilidade da obra devido aos parcos recursos utilizados:

Podrá la obra, cuya postura en escena requiere poco personal, casi ninguna escenografía, ninguna, y escasa ropa ("las únicas plumas las usa Cortés", nos anunció la autora) ser llevada, sin graves problemas, a escuelas, patios, reclusorios, atrios, canchas de basquetbol, lo que la hace muy recomendable. A todas partes podrá ir... menos a Tlaxcala. 
No entanto, a partir desse ponto, a resenha passa a se preocupar com a projeção histórica alcançada destacando com mais vagar o impacto que ela poderia ter nas comunidades indígenas daquela época:

Esta antigua nación, hoy un pujante estado, resulta severa y tal vez injustamente tratada; el criterio de la autora no resulta indigenista, o mexicanista, sino tenochca, aztequista; por nuestra patria actualmente entendemos no nada más la isla "ombligo de la luna" en que se paró el águila sobre un nopal, sino también sus alrededores, hasta ambos mares; tan antepasados nuestros son (podemos considerar) los tlaxcaltecas, los chichimecas, los toltecas, los tarascos, los olmecas, los mayas, como los habitantes del islote, que eran enemigos de sus vecinos tepanecas, chalcas o xochimilcas; pero también el México actual es producto no nada más de una fusión de todas aquellas tribus aborígenes, sino de los españoles que con ellas revolvieron su sangre tan nuestro abuelo es Cortés como Moctezuma y es parcial ponerse solamente de parte del uno y no del otro. (SOLANA, 1985)

O recorte temático nacionalista proposto por Solana não é aleatório, porquanto o diálogo intertextual com a Visão dos vencidos (1987) é explícito. A opinião do crítico é representativa de algumas mudanças que vinham sendo produzidas naquele contexto, dentre as quais as políticas de valorização e reconhecimento das nações indígenas. No campo crítico, a resenha foi também uma guinada porque não se limitava a assinalar os méritos da obra em função de modelos - como havia feito De María y Campos ao comentar a peça de Usigli — , mas reconhecia suas potencialidades para gerar uma discussão sobre um tema social complexo.

Em relação a La noche de Hernán Cortés, a gênese da obra é exposta pelo próprio Vicente Leñero em Vivir del teatro (2002). Conta que se dedicava à história do conquistador desde 1988 enquanto preparava um roteiro para uma série de televisão que Teo Escamilla, andaluz e fotógrafo de filmes de Carlos Saura, havia projetado com vistas à sua exibição no ano de comemoração dos quinhentos anos da chegada de Colombo às novas terras. Embora a série não tenha vingado, ele guardou o texto até que, por volta de 1990, foi escolhido para ser o representante do México na comemoração conjunta dos mais importantes festivais de teatro hispano-americanos e espanhol. ${ }^{157}$

Leñero confessa que pensou trabalhar inicialmente com a mesma fórmula utilizada em Compañero e Martirio de Morelos, nas quais se faz o julgamento dos

\footnotetext{
${ }^{157}$ A parceria foi firmada no Acordo de São José. Os festivais a que o dramaturgo se refere são conforme sua própria enumeração, os de Caracas, Bogotá, México, São José (Costa Rica), Cádiz, Montreal, Santiago do Chile e Buenos Aires.
} 
protagonistas, mas teria desistido por dois motivos. Um foi a descoberta do livro Un crimen de Hernán Cortés, do historiador Alfonso Toro, publicado em 1947. Segundo Leñero, nele há uma reprodução fidedigna do julgamento que o conquistador sofreu em 1528 sob a acusação de ter assassinado em Coyoacán sua esposa Catalina Suárez, la Marcaida $^{158}$. O segundo motivo foi a consciência de que, se usasse os mesmos procedimentos, estaria se convertendo em um mero reprodutor de fórmulas.

O relato de Leñero segue repleto de passagens saborosas e divertidas, cheio de suspense e frases contundentes, alimentado com peripécias e comentários impactantes sobre o teatro. Porém, nos limites desta pesquisa, podemos deduzir a partir de suas próprias palavras que a peça se ajusta a um novo sistema de produção cultural marcado, entre outros fatores, pelo aproveitamento de datas comemorativas para sobrevalorizar as obras. La noche de Hernán Cortés foi a única peça que sobreviveu ao projeto iniciado com o Acordo de São José. Todas as demais, que seriam escritas por autores renomados do universo hispânico, não foram sequer montadas.

No México, a estreia foi no teatro Julio Castillo (antigo Del Bosque) em abril de 1992. Victor Hugo Rascón Banda redigiu duas resenhas elogiosas publicadas em Proceso $^{159}$, uma de 30 de maio e outra de 6 de junho. Ressalta aspectos positivos, tais como a escolha dos episódios representados, a direção de Luis de Tavira, a cenografia de Alejandro Luna, o vestuário de Angeles Davidson e a música de Leopoldo Novoa. Embora nenhuma das duas resenhas faça menção à recepção do espetáculo, o aspecto é problematizado pelo próprio autor da peça: “Desde el estreno el público no respondió como ambicionábamos" (LEÑERO, 2012, p. 422). Ele confidencia que vários de seus amigos responsabilizaram a montagem por atrapalhar a comunicação do desejo de um ancião de reviver o passado, experiência principal do texto.

Comenta ainda que na Espanha não houve empatia com o público — razão segundo ele, explicável e esperada por causa do rebaixamento de Cortés. Entretanto, Armando Ponce e Sanjuana Martínez, que resenharam a estreia madrilenha, não compartilharam da mesma opinião. Em 24 de outubro de 1992, em Proceso, enfatizavam uma possível traição do diretor Luis de Tavira com relação ao texto de Leñero. Com esse mote, reproduziram na ocasião as opiniões do ator Fernando Balzaretti (Hernán Cortés), do próprio Tavira, de Arturo Azuela (diretor do Fondo de Cultura em Madri) e de algumas

\footnotetext{
${ }^{158} \mathrm{O}$ suposto assassinato está representado em La noche de Hernán Cortés.

159 As duas resenhas estão disponíveis online, em https://www.proceso.com.mx/159456/la-noche-dehernan-cortes e https://www.proceso.com.mx/159499/la-noche-de-hernan-cortes-ii, respectivamente.
} 
pessoas que assistiram ao espetáculo. Para os entrevistados, a montagem, além de não macular o texto, correspondia à complexidade da situação histórica representada.

Podemos concluir neste ponto que a montagem de cada uma das obras acompanha mudanças no sistema de produção cultural. Destaca em todas elas a baixa receptividade do público no momento da estreia, fator singular da teatralidade. Em termos literários, por outro lado, todas três são respeitadas pela crítica no que diz respeito à interlocução com a história e às estratégias ficcionais utilizadas.

\subsection{A reescrita de documentos}

O processo de Conquista do México foi um evento abundantemente registrado tanto por espanhóis quanto por indígenas. Crônicas, cartas, relaciones, códices e outros gêneros conformam um quadro variado e complexo que muitas vezes acentua determinados episódios ao sabor das subjetividades e perspectivas de seus autores: militares, clérigos, indígenas convertidos e historiadores. A farta documentação aliada às inúmeras divergências e lacunas propicia a imaginação e a reescrita literárias do acontecimento histórico em si e das interpretações construídas em diferentes momentos da história nacional.

Dentre os três autores que compõem a coluna vertebral de nosso trabalho, Vicente Leñero é certamente o que mais se dedicou a sustentar seu labor pelos rastros e vestígios escritos sobre os contatos iniciais entre mesoamericanos e europeus. No entanto, uma pesquisa mais detalhada mostra que os outros dois também lançaram mão da intertextualidade com os documentos em seu sentido mais convencional. ${ }^{160}$

Corona de fuego, de Rodolfo Usigli, dialoga com a biografia de Salvador Toscano (1959/1991) sobre Cuauhtémoc e trechos da crônica de Bernal Díaz del Castillo (1632/1977). ${ }^{161}$ Segundo o biógrafo, na chegada a Tuxakhá, o líder indígena teria pronunciado o seguinte ao povo de Acallan:

Esforzaos, nobles acallantlaca, lo más que podáis, con la ayuda de nuestros dioses. Estad contentos. No vayáis — añadió amargamente -

\footnotetext{
${ }^{160}$ Referimo-nos à noção clássica de documentos, isto é, aqueles registros predominantemente escritos, antes que ocorresse o que Jacques Le Goff (1992) chama de "revolução documental". Esse conceito faz sentido neste momento tendo em vista a forma de produção de provas à época do evento histórico referenciado.

${ }^{161}$ A execução de Cuauhtémoc aparece também na quinta Carta de Hernán Cortés, no registro de Francisco López de Gómara em La conquista de México (1552), e nos Anales de Tlatelolco.
} 
a pueblos extraños. Sed felices aquí, para que no ocasionéis dolor a las gentes del pueblo, a los viejos, a los ancianos, a los niños que están todavía en las cunas y a los que apenas comienzan a caminar, a los que están jugando. Tened cuidado con ellos y compadeceos de ellos. Que no se vayan a un pueblo extraño. Amadlos. No los abandonéis. Y os lo recomiendo expresamente, porque nosotros seremos enviados a Castilla. ¿Qué sé yo si regresaré o pereceré allá? Quizá no vuelva a veros. Haced todo lo que esté en vuestro poder. Amad a vuestros hijos tranquilamente y en paz. No les inflijáis ningún disgusto. Y sólo digo esto: ayudadme en alguna forma con algo para que yo pueda dar la bienvenida al gran señor que es soberano de Castilla. (TOSCANO, 1991, p. 230-231).

Em sintonia com o tom grandiloquente do texto histórico, o trecho é reproduzido quase integralmente na peça usigliana, ajustando-se à estrutura poemática: ${ }^{162}$

Nobles acallantlaca, os suplico que oigáis la voz de quien siente viejo como el destino. Os doy gracias cordiales. Esforzaos cuanto podáis, iy os ayuden los dioses!, por vivir unidos en esta tierra que es fértil y fecunda. No vayáis a otros pueblos extraños, ni en huida ni en conquista.

Sed felices aquí y no ocasionéis dolor a la buena gente del pueblo, a los nobles ancianos, a los a niños que todavía sueñan con Citlali en sus cunas, y a los que empiezan a saber el modo de caminar, y a los que juegan ya como fuegos o pájaros y miran ya al futuro. Es cuidado y piedad lo que os demanda. Es cuidado y amor. Si los amáis No se irán a pueblos extraños. No los abandonéis nunca. Os lo pido y recomiendo expresamente porque soy el padre y señor de todos y seré enviado con los míos a Castilla, y no sé si regresaré de allá o si he de perecer en sus riberas. (USIGLI, TCII, p. 799). ${ }^{163}$

Essas palavras são pronunciadas pelo prisioneiro apenas antes de ser executado, ou seja que, do ponto de vista discursivo, a inserção delas em momentos diferentes do episódio desloca o sentido heróico do protagonista. No registro histórico, elas carregam sentimentos de contestação, de recusa, de luta, porque deixam transparecer

\footnotetext{
${ }^{162}$ A estrutura das estrofes e dos versos nessa peça serve para caracterizar os Coros de espanhóis e indígenas. Enquanto o primeiro se expressa em decassílabos rimados, o segundo revela-se pelos versos brancos e livres.

${ }^{163}$ Além da aproximação não poder ser mais clara, o próprio Usigli apontou os procedimentos de escrita nas "Notas a Corona de fuego" (TC III).
} 
aos antigos povos sob seu jugo que o tlatoani não sucumbira diante da adversidade. Já no texto ficcionalizado, gera-se o efeito de que há a manifestação de um último desejo, uma súplica.

Outra marca da intertextualidade nessa peça é a recuperação de sentidos que, na fonte, são apenas esboçados. Isso se materializa na reatualização das palavras de Bernal Díaz del Castillo. Em sua narrativa, ele com frequência tece elogios às ações de Cortés. No capítulo em que narra a morte de Cuauhtémoc, porém, o comentário parece reprovar a atitude: " $Y$ fue esta muerte que les dieron muy injustamente dada, y pareció mal a todos los que íbamos en aquella jornada". (DÍAZ DEL CASTILLO, 1977, p. 205). Essas palavras são recuperadas no último ato da peça, quando já não pairam dúvidas de que Cuauhtémoc será executado: “Siempre, Príncipe, te recordaré. / 'Mal parece tu muerte a todos'. Yo lo sé." (Usigli TCII, p. 838).

A comparação dos dois trechos revela que o deslocamento consiste em fazer a personagem Bernal Díaz se exprimir diretamente ao tlatoani. A mudança discursiva decorre da eliminação do verbo "ir" na primeira pessoa do plural ("íbamos en aquella jornada”). A princípio, isso sugeriria a tentativa de obedecer a métrica, mas a omissão faz com que se reatualize o tempo da experiência narrada. Concomitantemente, o uso dos verbos no singular ("recordaré" e "sê") reorganiza os fatos de maneira que se ressalta a possível compassividade do olhar de Bernal Díaz frente ao gesto de Cortés, sentido apenas latente na crônica original. Com esse deslocamento, enfim, sua figura é revalorizada enquanto cronista, historiador, personagem particularmente responsável pelo registro e pela articulação dos acontecimentos. ${ }^{164}$

A intertextualidade com os documentos históricos exerce função primordial também em Águila o sol, de Sabina Berman. A apropriação que a dramaturga faz da compilação de Miguel León-Portilla se torna ainda mais complexa quando comparada ao procedimento de Rodolfo Usigli. Além da quantidade de trechos utilizados, a subversão dos sentidos é mais drástica. Ela pinça os relatos indígenas em suas versões originais, de modo que a peça ganha contornos épicos.

O quadro de abertura ("Los presagios”) ilustra essa articulação inteiramente particular com o texto original e sua transposição para o texto dramático. Nele, um Mariachi, um Coro e um Narrador alternam as falas para anunciar os agouros e notícias dos europeus:

\footnotetext{
${ }^{164}$ Nesse sentido, mais uma vez identificamos que Rodolfo Usigli acentua o papel dessas personagens, tal como fizera em El gesticulador e nas outra Coroas.
} 


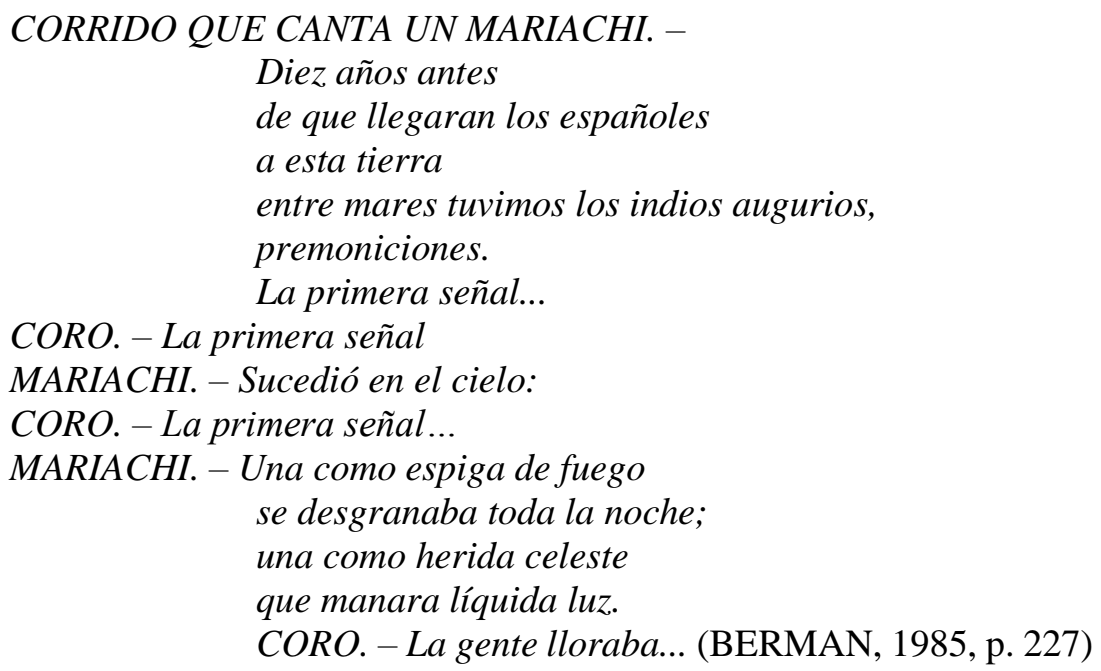

As personagens coletivas, que historicizam o evento a ser mostrado reproduzem as palavras que León-Portilla (p. 26) recolheu do Códice florentino: "Primeiro agouro: Dez anos antes de virem os espanhóis apareceu um longo agouro no céu. Algo como uma espiga de fogo, como uma chama de fogo, como uma aurora: aparecia como se estivesse gotejando, como se estivesse rasgando o céu."

No entanto, quanto ao conteúdo explorado, esse exercício de apropriação que quase beira à cópia não objetiva a revelação de fatos desconhecidos. Tampouco tem o intuito de engrandecimento ou de conscientização, como sói acontecer com o teatro épico. Pelo contrário, alguns quadros, sobretudo os de tom metateatral, promovem inclusive comicidade.

Essa modificação da tonalidade séria dos registros históricos para a comicidade que o texto cênico assume a partir do literário se revela especialmente na representação da morte de Moctezuma. Dentre as divergências da Conquista, esse episódio ocupa um lugar privilegiado. Inúmeros debates foram travados ao longo das décadas sobre como ele teria morrido. As hipóteses mais conhecidas estão nos testemunhos de Fernando de Alva Ixtlilxóchitl, autor da XIII relación, e dos informantes de Sahagún, ambos presentes nos relatos compilados na Visão dos vencidos.

Ixtlilxóchitl afirma que não se sabe ao certo se o líder asteca teria sido assassinado pelos espanhóis ou por um homem revoltado enquanto o tlatoani tentava persuadir a população a se render aos europeus: "[...] dizem que um deles the acertou uma pedrada da qual morreu; ainda que seus servos digam que os próprios espanhóis o mataram, e pelas partes baixas lhe enfiaram a espada." (p. 97). Nesse relato, das duas possíveis causas da morte, destaca-se, por um lado, a fatalidade de ter sido atingido pela pedra e, por outro, a 
brutalidade dos invasores. Ambas as versões são, como se vê, dicotômicas e por isso não projetam uma representação idealizada do líder asteca.

Já os informantes de Sahagún narram que durante a Matança do Templo Maior Moctezuma teria saído de sua casa real e proferido algumas palavras incentivando a conciliação entre os conflitantes:

E quando o sol ia ocultar-se, quando havia apenas um pouco de sol, veio a dar pregão Itzcuauhtzin ${ }^{165}$, desde a açoteia gritou e disse:

- Mexicanos, tenochcas, tlatelolcas: lhes fala o vosso rei, o senhor, Motecuhzoma: os manda dizer: que o ouçam os mexicanos:

- Pois não somos competentes para igualá-los, que não lutem os mexicanos. Que se deixe em paz o escudo e a flecha.

$[\ldots]$

Quando acabou de falar Itzcuauhtzin lhe dirigiram uma grande gritaria, lhe disseram opróbios. Se aborreceram ao extremo os mexicanos, raivosos se encheram de cólera e lhe disseram:

- O que é que diz esse maldito Motecuhzoma: Já não somos seus vassalos! (LEÓN-PORTILLA, 1987, p.87)

O tópico da conciliação está presente nas duas versões, apesar de também sugerirem a brutalidade e a fatalidade dos acontecimentos. Nesse sentido, a tentativa conciliadora, por si só, poderia ser significativa para o imperador passar à história como alguém pouco digno de ser lembrado. No entanto, a pedrada como sendo a causa mortis põe ênfase na fatalidade. Isso é visto na continuação do trecho acima. Ainda segundo os informantes do frei Bernardino, enquanto Cortés regressava da luta contra Pánfilo de Narváez, Moctezuma, já sob o poder dos europeus, vendo que os astecas investiam contra os adversários, "se pôs numa parte alta, e repreendeu-lhes". Os repreendidos teriam rejeitado as palavras do grande tlatoani, que sob ameaças e a acusação de traidor, “inimigo de sua pátria”, teria recebido uma pedrada, causa de sua morte. (LEÓNPORTILLA, 1987, p 96).

Essa mesma versão é narrada pelo próprio Hernán Cortés:

Montezuma, que ainda estava preso com um filho seu e alguns senhores, pediu-me para deixá-lo subir até o terraço da fortaleza de onde falaria aos capitães daquela gente, pedindo-lhes que parassem a guerra. Eu concordei, mas bastou ele começar a falar para ser atingido por uma pedra, que provocou sua morte três dias depois.

(CORTEZ, 1986, p. 54) 166

\footnotetext{
${ }^{165}$ Filho e porta-voz de Moctezuma.

${ }^{166}$ Ao longo do trabalho optamos por manter a ortografia castelhana no registro do nome de Hernán Cortés. Porém, como a leitura das cartas realizou-se a partir de uma edição brasileira, sempre que nos referirmos a essa publicação usaremos Cortez, conforme está na capa.
} 
Entre a brutalidade e a fatalidade, Sabina Berman opta pela segunda ao representar a tragédia do líder indígena. No último quadro de Águila o sol, intitulado justamente "Moctezuma", antes dele fazer o discurso em favor da rendição, um Soldado anuncia-o: "SOLDADO. - (alta la voz anunciando.) Meksicanus, tenoshkas, tlatelolcas y anexas: les va a hablar su emperador Moctezuma." (p. 262). Uma vez que "soldado" seria forma de designar um integrante das tropas europeias, a escolha da representação ortográfica da pronúncia inglesa (“meksicanus”) e a generalização dos demais povos mesoamericanos (“anexas”) são representantes da verve crítica da autora.

Moctezuma, então, profere seu discurso:

MOCTEZUMA. - Mexicanos, tenochcas, tlatelolcas: pues no somos competentes para igualar a los forasteros, que no luchen los mexicanos. Que se deje el escudo y la flecha. Los que sufren son los viejos, las viejas, dignas de lástima. Y el pueblo de clase humilde. Y los que no tienen discreción aún: los que apenas intentan ponerse en pie, los que andan a gatas ${ }^{167}$; los que están en la cuna y la camita de palo: los que aún nada se dan cuenta. (p. 262)

Se comparamos o trecho acima com a versão de León-Portilla (1987) acima transcrita, verificamos a "fidelidade" aos documentos. No entanto, o tom épico e conciliador do discurso é impactado pelo dinamismo da sequência - em termos gráficos, ocupa somente uma página e meia. Depois desse pronunciamento, uma Índia profere palavras contrárias, manifestando total desaprovação ao que pede o tlatoani: ¡Ya cállate Moctezuma!" Depois, um Índio “alista una piedra en una honda [...] y silba una 'mentada de madre' al tiempo en que lanza la piedra." (BERMAN, 1985, p. 264). Moctezuma cai imediatamente. A velocidade da movimentação do quadro, a quebra do efeito de grandeza épica e a linguagem corriqueira usada para insultar enfatizam a comicidade da cena e, consequentemente, desmobilizam uma possível representação grandiosa da liderança asteca. Mesmo sendo possível interpretar como contestatória a postura dos dois índios envolvidos no final, o teor implicado no desenvolvimento do episódio é de denegação.

A tensão entre o tratamento trágico da historiografia e o tratamento cômico da peça se expressa também em determinadas cenas metateatrais. Em "Teatro Callejero", enquanto é assistido por Espectadores, um grupo de Cômicos discute a relação dos

\footnotetext{
${ }^{167}$ Embora o trecho seja por demais aberto a interpretações devido à ambiguidade da frase construída pelo contexto, não poderíamos deixar de ressaltar que "andar a gatas" é uma gestualidade muito explorada em La grieta. Nesta última, andar de gatinhas é sinal claro de submissão.
} 
tlaxcaltecas com os espanhóis. Essa cena recupera a longa divergência sobre a "cumplicidade" desse povo indígena na invasão. No início, os Cômicos estão narrando aos Espectadores o avanço dos espanhóis pelas terras da nação que se tornou aliada de Cortés. Nessas palavras, o tratamento estético de espanhóis e indígenas visa à "ridicularização":

Cómico 1. - Pues que ya bajaron a tierra los susodichos.

Cómico 2. - ¿Los carita de tortilla, pelo de maíz?

Cómico 1. - Qué ya se vienen pa' cá. Que ya les salen al encuentro los señores de Tlaxacala. [sic]

Cómico 2. - Ora sí vamos a ver cómo pelean los güeros.

Cómico 1. - ¿Contra quienes? Si los señores de Tlaxcala se les agacharon.

Cómico 2. - ¡¿Cómo?!

Cómico 1. - ¿Cómo que cómo? Así. (Empina al otro: queda doblado sobre su cintura mientras el cómico 1 hace tras él señas de que se lo va a fornicar por atrás.) Así se les agacharon los señores de Tlaxcala, tú chúpate el dedo. (BERMAN, 1985, p. 240)

A última fala e, principalmente, sua gestualidade convocam a rememoração do tratamento dado à questão da masculinidade na formação da identidade mexicana. Conforme vimos nos ensaios de interpretação da mexicanidade, sobretudo a respeito do papel do "pelado" em Samuel Ramos, o tema do machismo apresenta dimensões mais amplas e profundas. Contudo, a cena não é uma completa invenção de Sabina Berman.

Esse quadro está pautado no capítulo V da Visão dos vencidos, intitulado "Os espanhóis começam a marcha: chegada a Tlaxcala e Cholula". Reproduz assim o relato da aliança e a consequente matança de Cholula. Nesse registro em espanhol feito originalmente por Diego Muñoz Camargo na Historia de Tlaxcala, a voz narrativa conta que os habitantes de Cholula, antes da chegada dos confederados que realizariam a matança, expressavam segurança de que teriam a vitória porque Quetzalcóatl estava do lado deles. Para se referir aos "estrangeiros" que pretendiam invadir sua cidade, usavam a expressão "sodomitas afeminados". Os tlaxcaltecas, ainda segundo esta versão, não eram "mais do que mulheres barbadas de seus homens barbudos, que se entregaram a eles por puro medo.” (LEÓN-PORTILLA, 1987, p. 58).

No fim do quadro, vemos comparecer certa resignação de parte dos Cômicos, sentimento esse que acaba por adotar um sentido humorístico provocado pela repetição exaustiva do conjuntivo "pues", que é marca peculiar da oralidade mexicana:

Cómico 2. - Ya estese sosiego porque me voy.

Cómico 1. - Es que se les arrimaron pues. 
Cómico 2. - Pero eso ya me lo contó pues.

Cómico 1. - Pero es que me tiene rete impresionado pues.

Cómico 2. - Pero pues no me mires así, ¿no?

Cómico 1. - Pues, ¿cómo entonces, si nomás tengo estos ojos para verlo(la)?

Cómico 2. - Es que nadie me había mirado así, pues.

Cómico 1. - Pues ya ve pues. Es que 'ta re lindo (da) pues.

(BERMAN, 1985, p. 242)

Qual o efeito de sentido gerado por cenas como as anteriores? Sabina Berman, autora declaradamente feminista, escolhe inserir um quadro em que a gestualidade representa a sodomia apenas referida pelo narrador na versão tlaxcalteca mas que, afinal, irá tratar com humor. Com efeito, se a escolha da Visão dos vencidos como substrato intertextual significaria poder conferir autoridade e legitimidade à voz do indígena, ao tornar cômicos esses episódios eles parecem se afastar do propósito inicial. Dessa forma, a reescrita da história se torna mais polêmica porque relativiza totalmente tanto o papel dos espanhóis quanto o dos indígenas. Essa postura de quem maneja uma arma duplamente cortante produz impacto nas leituras e releituras da história mexicana, tornando evidente que a direção do golpe desferido não é nem contra nem a favor do passado, mas se posiciona diretamente no contexto imediato dos anos 1980.

Isso fica mais evidente ao analisarmos a continuação do relato tlaxcalteca selecionado por León-Portilla. De acordo com a voz narrativa, os cholultecas diziam o seguinte dos aliados dos espanhóis:

Deixai que cheguem os vendidos, que paguem os miseráveis com a vida. Olhai os tlaxcaltecas pervertidos, covardes, merecedores de castigo: como se acham vencidos pelos mexicanos, andam procurando forasteiros para se defenderem. Como mudaram em tão pouco tempo, como se rebaixaram para uma gente tão bárbara e forasteira, estrangeira, de um mundo não conhecido? (p. 58)

Como vemos, os cholultecas eram contrários aos aliados porque estariam vendidos aos "forasteiros", aos "estrangeiros", a "uma gente bárbara", de "um mundo desconhecido". Observando a questão dentro do contexto econômico e político em que a obra foi escrita, devemos lembrar que um dos principais motivos de questionamento da identidade nacional era a abertura para o capital estrangeiro, motivada por dívidas acumuladas e pela má gestão das décadas anteriores. Também no universo teatral, como já comentamos antes, predominava ainda uma ideia de que não havia bons dramaturgos mexicanos e que por isso as obras estrangeiras deveriam preencher os palcos, inclusive 
com apoio estatal. Portanto, verificamos que o grau de elaboração dos documentos nessa peça de Sabina Berman oferece auspiciosa ampliação de recursos ficcionais que ressignificam a historiografia e a perspectiva nacionalista que ainda predominava na obra de Rodolfo Usigli.

Já em La noche de Hernán Cortés a relação com os documentos históricos se dá de distintas maneiras, sobretudo no que tange à fidelidade aos registros. Nessa peça, o trabalho com a documentação apresenta-se de três maneiras: por aproveitamento, apropriação e reinvenção.

O aproveitamento manifesta-se pela inserção do documento com vistas a arquitetar a obra ficcionalizada. Diríamos que é a camada que consagrou Vicente Leñero em seu fazer dramatúrgico. Nessa peça, assim como em tantas outras, há no final do texto uma "Bibliografia" com algumas referências utilizadas. Ali se identifica de maneira clara o substrato textual de fontes primárias (tais como as crônicas Bernal Díaz del Castillo, Francisco López de Gómara e Fray Bernardino de Sahagún e as Cartas de Hernán Cortés), secundárias (de Miguel León-Portilla e William H. Prescott), ensaios interpretativos (tais como o Laberinto de la soledad de Octavio Paz) e biografias do protagonista (por exemplo a de Salvador Madariaga). Finalmente, explicita-se que a obra tem "una deuda impagable con el libro de José Luis Martínez”" (LEÑERO, TC II, p. 477), o qual reproduz os autos do julgamento sofrido por Cortés à revelia sob a acusação de ter matado a esposa Catalina Suárez.

No corpo do texto, o aproveitamento se realiza pela articulação dessas fontes com algum acontecimento em cena. A estratégia acontece, por exemplo, no primeiro quadro de Cempoala, no momento em que o conquistador está estuprando Malintzin. Enquanto Cortés promove a violência, o Secretário e o Anão caminham em direção a Sevilha. Nesse deslocamento, "el secretario va dictando al enano la lección antropológica" (LEÑERO, TC II, p. 456) que se encontra no ensaio "Los hijos de la Malinche", de Octavio Paz:

SECRETARIO (pedagógico): Doña Marina se ha convertido en una figura que representa a las indias fascinadas, violadas o seducidas por los españoles. Y del mismo modo que el niño no perdona a su madre que lo abandone para ir en busca de su padre, el Pueblo mexicano no perdona su traición a la Malinche. De ahi el éxito del adjetivo despectivo "malinchista", a todos los contagiados por tendencias extranjerizantes. Los malinchistas son los partidarios de que México se abra al exterior: los verdaderos hijos de la Malinche, que es la Chingada en persona. 
(LEÑERO, TC II, p. 456 / PAZ, 1994, p. 94-95)

Denominamos aproveitamento esse tipo de incorporação de documentos no texto porque não existem reelaborações no interior do trecho escolhido. Apesar disso, não se pode negar a carga simbólica que o excerto assume quando passa do contexto de um livro de ensaios de interpretação à composição de uma cena de estupro, sobretudo porque especialmente nessa peça em nenhum momento Malintzin se demonstra partidária do estrangeiro. ${ }^{168}$ Com efeito, o vínculo desse trecho com a cena de estupro descontrói a relevância que o texto canônico de Octavio Paz adquiriu, principalmente fora das fronteiras mexicanas. ${ }^{169}$

Já a apropriação trabalha com a reformulação deliberada de certos trechos para os ajustar ao episódio, quadro ou cena. Na peça de Leñero, esse recurso se manifesta pela junção de trechos de documentos diferentes. É o caso das palavras ditadas por Cortés ao Secretário logo no início da peça, quando o memorialista faz esforços para registrar as reminiscências. O texto se abre com trechos do historiador William H. Prescott (17961859) e se encerra com uma frase de Voltaire, inserida em seu Essai sur les moeurs et L'esprit des nations.

CORTÉS: ¡Silencio! (Pausa. Se concentra. Dicta:) Cortés tuvo que aprender por propia experiencia, que la gratitud de una corte es más en proporción a lo que se promete de lo futuro que a lo que ha recibido de lo pasado. Así que su posición era la de un litigante importuno, cuyas reclamaciones de tierras y encomiendas y títulos en la Nueva España, aunque justísimas, resultaban a la corte demasiado grandes para ser atendidas desde luego. (Pausa.) Un día, Cortés, no pudiendo tener audiencia del emperador Carlos V... (LEÑERO, TC II, p. 427) $)^{170}$

A seguir, o invasor é interrompido pelo Secretário, que contesta a negativa da audiência. Ele, então, repreende o escrivão com o argumento de que "Nosotros no relatamos incidentes, nosostros escribimos la verdad histórica” e o manda registrar que um dia ele teria aberto caminho pela multidão e, na frente de todos, teria se apresentado ao monarca como "el que os ha dado más reinos que ciudades os dejaron vuestros padres". No entanto, pela maneira como foi elaborado, a autoria do registro deveria ser atribuída a outra pessoa. Isto é, a forma de incorporação da frase à ação pretende simular que seria aleatória a escolha do nome Voltaire como o autor dela:

\footnotetext{
${ }^{168}$ Pelo contrário, conforme se verá mais adiante, parece a todo instante espreitar Cortés para atacá-lo. ${ }^{169}$ No mesmo ano de estreia da peça, 1992, Margo Glantz problematizou o mesmo ensaio de Paz em "Las hijas de la Malinche". Ao discutir a emergência de expressivo número de autoras no fim do século XX, ela questiona a concepção machista que poderia estar por trás do ensaio do poeta.

${ }^{170} \mathrm{O}$ trecho que está em Prescott (s/d, p. 578) vai até a "pausa".
} 
CORTÉS: Y eso, que lo firme...

SECRETARIO: ¿Qué cosa, señor?

CORTÉS: Lo que acabas de escribir... Que lo firme... ¿Quién te gusta, Pancho? (Pausa.) ;Voltaire!

SECRETARIO: ¿Voltaire? ¿ François Marie Voltaire?

CORTÉS: "C'est, répondit Cortés, celui qui vous a donné plus d'etats que vos péres ne vous ont laissé des villes".

(LEÑERO, TC II, p. 427-428 - aspas no original)

O jogo de simular uma autoria inventada traz duas consequências imediatas. A mais elementar é a amplificação das possibilidades para reelaborar a própria teatralidade documental, uma vez que a frase, embora seja realmente do filósofo iluminista, não consta da Bibliografia indicada no final. Além disso, do ponto de vista do diálogo com a historiografia, esse gesto abre a discussão sobre o papel do historiador enquanto responsável por dar sentido a certos acontecimentos ou enquanto testemunha deles. Parece que a "preferência" de Cortés agora é por ser visto como "objeto de discurso histórico" (HAMBURGUER, 1986 e KOSELLECK, 1993) e não como testemunha de todo o processo, algo que em sua época era mais valorizado.

Tratando ainda da apropriação, identificamos que algumas personagens se expressam com textos que na historiografia possuem outra autoria. Em Sevilha, Cortés e o Secretário querem lembrar o nome do Cacique Gordo de Cempoala, bem como a própria terra sob seu domínio. Em meio a reminiscências de outros lugares e nomes, dá-se o seguinte diálogo:

SECRETARIO: Lo estamos viendo, señor.

CORTÉS: Dime qué ves, Pancho.

SECRETARIO: No vemos ya al Cacique Gordo de Cempoal, señor.

CORTÉS: Dime que ves entonces, Pancho.

SECRETARIO: Una gran cordillera de sierras muy hermosas. Y algunas de ellas son en gran manera muy altas. Entre las cuales hay una que excede en mucha altura a todas las otras, y della se ve y descubre gran parte de la mar y de la tierra. Y es tan alta...

(LEÑERO, TC II, p. 430)

O trecho destacado são palavras de Hernán Cortés retiradas de sua primeira Carta de relación, texto sobre o qual pairam dúvidas da autoria porque a original teria desaparecido. Percebemos que inclusive foi mantida a ortografia mais próxima do século XVI em "della". 
Outro ponto de deslocamento da autoria se dá no momento em que o memorialista, duvidoso de ter realizado uma festa em Coyoacán, ordena que o Secretário busque em Bernal Díaz (um dos nomes que atribui a ele) a comprovação do acontecimento. Ele encontra o texto em meio aos diversos papéis: "SECRETARIO: ¡Aquí está!, ¡aquí está!... Teníamos toda la razón. Bernal escribió efectivamente la crónica de la fiesta. (Lee.)" (LEÑERO, TC II, p. 446). Nesse ponto, podemos perceber como o Secretário assume uma função coletiva, porque, embora seja às vezes chamado de Bernal Díaz, nessa frase mostra que realmente não é.

Dessa conjugação de documentos reelaborados com outros que, mesmo sendo reais, se apresentam como simulacros, passa-se sutilmente à articulação inventiva dos vestígios históricos. Esse procedimento consiste em criar a sensação de realidade, de incorporação documental de registros que não existem. É o caso do relato que Cortés faz aos convidados da festa em Coyoacán sobre seu encontro com Moctezuma. Embora a descrição conste das Relaciones do conquistador, chama atenção o fato de que o Secretário seja convocado para o auxiliar a recordar o episódio:

SECRETARIO: Sí, señor, Motecuzoma o Moctezuma. Entendemos que es lo mismo. Moctezuma Xocoyotzin. Noveno señor azteca. Fue hijo de Axayácatl y sucedió en el trono del imperio a su abuelo Ahuízotl. (Leyendo de los papeles.) El ocho de noviembre del año del Señor de 1519, salió a recibir a nuestro capitán general don Hernando de Cortés, en la calzada de Iztapalapa, frente al templo de la diosa Toci.

(LEÑERO, TC II, p. 433)

$\mathrm{O}$ ato de ler, recorrente nas movimentações do Secretário, instaura cenicamente o documento na ação. A peculiaridade do trecho acima é que ele é redigido de maneira semelhante à da escrita historiográfica, apesar de não existir enquanto fonte. Portanto, a elaboração textual nos mesmos moldes de diversos cronistas do século XVI garante a simulação documental, deixando transparecer que o conteúdo que ele expressa teria acontecido.

Esse recurso cresce gradualmente e chega ao ponto de haver "registro" de um episódio que propõe a reformulação radical da história. Trata-se da morte de Cortés que no retorno à Cempoala é atingido por várias flechas e assassinado pela Malinche. Moribundo, o capitão ordena que o escrivão coloque o fato nos seguintes termos: 
que enviado por el gobernador de Cuba, don Diego de Velázquez, había desembarcado en Cozumel con once navios, quinientos ocho soldados, cien marinos y dieciséis caballos para descubrir nuevas tierras, fue muerto por heridas de flechas y lanza durante una feroz batalla en un pueblo llamado de Cempoal... (LEÑERO, TC II, p. 474)

Como vemos, o esmero na apropriação dos documentos históricos se avoluma com o tempo. Rodolfo Usigli incorpora fontes primárias a Corona de fuego, sem modificar substancialmente o texto. A fonte não é indicada explicitamente, isto é, não está incorporada ao texto dramático, mas aparecerá tempos depois em forma de ensaio como comprovação de seu conhecimento histórico, a fim de justificar que traíra a história.

Por sua vez, Sabina Berman desde a primeira publicação de Águila o sol expõe o diálogo intertextual direto com a historiografia. As fontes são utilizadas para caracterizar Moctezuma e se contrapõe à estilização da fala de Cortés e à forma poética da Malinche.

Finalmente, em La noche de Hernán Cortés, a morte do capitão espanhol por sua intérprete é impactante e, ao mesmo tempo, paradoxal no que diz respeito à fidelidade aos documentos. Vicente Leñero talha os registros históricos de primeira ou segunda ordem, de modo que a reescrita demonstra a força da plasmação linguística na produção de outros sentidos e mundos. Essa escolha pela subversão total dos vestígios deixados pela história faz com que a representação se transforme em invenção, não pelo que há de inventivo em toda criação estética, mas pela possibilidade de criar outra realidade histórica a partir da escrita. No caso específico de Malinche e Cortés, trata-se, obviamente, de uma morte simbólica. $\mathrm{O}$ recurso propõe um novo passado à medida que elimina a construção imaginária que perpetua padrões comportamentais de submissão e passividade frente ao estrangeiro. ${ }^{171}$

\footnotetext{
${ }^{171} \mathrm{Na}$ entrevista concedida a Armando Ponce e Sanjuana Martínez, o diretor, Luis de Tavira, abordou a subversão da auto-imagem mexicana. Quando questionado sobre a possível traição ao texto de Leñero, respondeu o seguinte: "Sí hay diferencias, pero en ningún momento traición. Hubo otro tipo de ataque e interpretación del texto a través de una lectura ideologizada y prejuiciada por un indigenismo a ultranza que contrasta con otras opiniones en Europa. Al contrario, no hay malinchismo, los europeos sienten una postura muy mexicana y promexicana en un sentido de mexicanidad que les resulta sumamente original y que desgraciadamente en nuestro propio país resultó escandalosa, quizá porque todavía haya mucha demagogia en un nacionalismo trasnochado que no acepta pasos nuevos, invenciones nuevas de nuestra propia identidad."
} 


\subsection{A relação La Malinche - Cortés}

O eixo de nossa análise neste momento é a relação entre Malinche e Hernán Cortés. O objetivo é vasculhar o modo como os autores aqui estudados figuraram a relação dessas personagens no processo de conquista da Mesoamérica. Pode-se dizer que nessa relação reside a concentração do conflito dramático, aspecto que Lukács (2011) considerava da mais alta relevância nos dramas históricos. De fato, apesar dos inúmeros agentes da Conquista do México, o "casal” amalgama a história e o imaginário nacionais em sua simbologia, sobretudo a partir dos movimentos de independência no século XIX. Por isso, críticos como Cypess (1991) atribuem à Conquista a função de um penetrante subtexto da cultura mexicana e, nesse contexto, Malinche seria um palimpsesto capaz de simbolizar "a primeira mulher da nação mexicana e a Eva mexicana, símbolo da traição nacional". (p. 2). ${ }^{172}$

Como sabemos, Malinalli, Malintzin ou Doña Marina, ${ }^{173}$ antes de ser entregue a Hernán Cortés em Tabasco, fora uma princesa asteca renegada por seu povo. Serviu bem aos propósitos do capitão espanhol principalmente por dominar as línguas náhuatl e chontal. Como a comunicação oral fez parte do processo de invasão, isto é, antecipava o enfrentamento armado, ela está tão atrelada ao conquistador que assumiu o nome com que algumas nações inicialmente designavam o capitão - Malinche. Seu lugar na história foi construído aos poucos até que, entre as décadas de 20 e 50 do século XX, o termo "malinchismo" irrompeu no vocabulário político como sinônimo de traição.

$\mathrm{Na}$ literatura os primeiros registros mais significativos surgem no romance Xicoténcatl (1826), de autoria desconhecida. Nesse momento, ela ainda não carregava o estigma negativo. Embora fosse uma das personagens responsáveis por armar complôs, traições e enganos, reconhece-se ali também sua condição de vítima. Em um trecho do romance, ${ }^{174}$ é dada voz à personagem. Em sua fala transparece a visão segundo a qual os vícios e as artimanhas que a teriam tornado traidora originaram-se do contato com os

\footnotetext{
172 "The first mother of the Mexican nation and the Mexican Eve, symbol of national betrayal."

${ }^{173}$ Por se tratar de um tema amplamente debatido nos mais diversos ramos das ciências sociais e da literatura, não aprofundaremos as informações sobre a Malinche. Sugerimos a leitura de Sandra Messinger Cypess, La Malinche in Mexican literature: from history to myth (1991).

${ }^{174}$ Eis o trecho completo. "Cuando yo seguía mi culto sencillo y puro, pues que salía de mi corazón: cuando yo era una idólatra [...] yo fui una mujer virtuosa [...] pero desde que fui cristiana, mis progresos en la carrera del crimen fueron más grandes que las hermosas virtudes de Teutila. Abjuro para siempre de una religión que me habéis enseñado con mentira, con la intriga, con la codicia, con la destemplanza y, sobre todo, con la indiferencia a los crímenes más atroces." (Anónimo, 1964, p. 161 apud GRILLO, 2011, p. 20).
} 
cristãos. Dessa relação religiosa, fica implícito também o sentimento de culpa decorrente da consciência do erro e do pecado, ou seja, da traição.

Mais recentemente, essa personagem tem recebido tratamento cuidadoso e revisionista na esteira do pensamento pós-estruturalista e da crítica feminista. O motivo dessa nova postura é o aumento de obras literárias, romances, peças teatrais e poemas, em grande medida escritos por mulheres, que visam a desconstruir estereótipos e preconceitos atribuídos a ela, ${ }^{175}$ cuja presença não é tão frequente na literatura do período da Conquista. Cortés, por exemplo, a menciona muito rapidamente apenas uma vez, em uma de suas cinco cartas. De fato, Marina, nome cristão que ele lhe atribui, aparece na quinta Relação, enquanto ele relata sua conversa com Canec, o senhor de Tiac, pequeno povoado da Península de Yucatán. É nesse trecho que o conquistador conta que a recebeu junto com outras vinte mulheres. (CORTEZ, 1986, p. 128).

Dos registros testemunhais, talvez o mais expressivo seja o de Bernal Díaz del Castillo. Isso é reconhecido por Margo Glantz (2001, s/p):

Bernal la menciona invariablemente y, a pesar de que su labor como lengua ha merecido un capítulo entero de encomio, cree necesario reiterarlo capítulo tras capítulo, aunque aparezca siempre en pareja con Jerónimo de Aguilar, pero su admiración hacia ella es explícita y categórica, y muy pocas veces elogia la habilidad o la diligencia del intérprete español.

O texto dessa grande crítica mexicana permite problematizar pontos nodais da atuação da ex-princesa na Conquista porque a coloca lado a lado de outro "língua" de Cortés, Jerónimo de Aguilar, ${ }^{176}$ cuja figuração na ficção e no imaginário não é tão relevante quanto o da mulher. A recuperação do papel desse intérprete torna-se premente pela capacidade de desvelar que ela não agia diretamente. O processo de tradução que compunha a entrada na Mesoamérica é confirmado pelo antropólogo Arturo Warman (2003, p. 91): “Cortés hablaba y exigía la rendición en español, Aguilar traducía al chontal, Marina al náhuatl y alguien al idioma local; la respuesta recorría el camino inverso." Assim, ao identificarmos que Doña Marina não foi “a” intérprete de Cortés, mas sim uma delas, podemos questionar por que ela passou à história, à literatura, enfim, ao

\footnotetext{
${ }^{175}$ Para citar apenas algumas: El eterno feminino (1975), de Rosario Castellanos, Malintzin y el señor Cortés (1995), de Helena Alberú de Villava, Amor y conquista. La novela de Malinalli mal llamada la Malinche (1999), de Marisol Martín del Campo, El sueño de la Malinche (2000), de Marcela del Río; Malinche (2006), de Laura Esquivel e, La verdadera historia de la Malinche (2009), de Fanny del Río.

${ }^{176}$ Náufrago espanhol que ficara muito tempo sob domínio maia e de quem aprendeu a falar, além da língua desse povo, o chontal.
} 
imaginário como uma personagem simbólica. A questão é que o fato de ser mulher e indígena mexicana está na raiz do problema que a leva a compor a memória coletiva. Traição, culpa, pecado: questões espinhosas da Conquista e de muitos episódios históricos do século XX - de acordo com o que vimos anteriormente - fazem com que ela retorne uma e outra vez na história e na literatura.

Da mesma forma que Malintzin absorveu uma série de conotações pejorativas ao longo da história e que só atualmente tem sido ressignificadas, o imaginário forjou as mais diferentes representações de Hernán Cortés. Para ficarmos no contexto de maior proximidade aos acontecimentos, trazemos para o debate as crônicas de Bernal Díaz del Castillo, Francisco López de Gómara e as próprias Cartas de Relación do conquistador.

Em cada um desses autores, o ethos do protagonista sofre profundas mudanças. Francisco López de Gómara conheceu Cortés quando tinha trinta anos e já era considerado um grande humanista. Ele se tornou seu capelão e primeiro biógrafo quando escreveu Historia general de las Indias a partir de longas conversas que teve com ele na Espanha.

Gómara não participou das ações, situação que lhe rendeu críticas desde que publicou sua versão dos fatos. Já no século XX, sofreu de um quase total esquecimento no campo da historiografia, conforme afirma o historiador Ramón Iglesia em estudo de 1942. Por esses anos, ainda era reprovado por não ter vivido a experiência da Conquista nem sequer ter ido à Nova Espanha e, sobretudo, por usar um tom grandiloquente em sua Historia. Para Iglesia (1942, p. 141-142), a preferência dos historiadores de seu período pela obra de Bernal Díaz se devia a que, nas páginas deste último, "no obstante sus continuadas protestas de lealtad y admiración corre un descontento apenas reprimido contra Cortés, un deseo enconado de rebajar sus méritos; mientras en las de Gómara se glorifica al conquistador." Para aumentar os motivos da rejeição, Gómara demonstra uma concepção de história muito arraigada na sobrevalorização do herói conquistador.

Ao contrário, Bernal Díaz del Castillo, o cronista que fora soldado da expedição de Cortés tem valor testemunhal porque participou de lutas, vivenciou perigos e glórias. A vivência do evento o autoriza a todo momento a questionar os relatos de Gómara, chamando-o mentiroso, principalmente no que diz respeito às informações que contabilizam número de soldados e à existência de certos episódios e batalhas.

Porém, a leitura de sua Verdadera historia... não esconde a imagem de um homem que, tal como o capitão de sua esquadra, reivindica seu lugar na posteridade e deseja ser gratificado pela sua participação. Ramón Iglesia acredita que ele se ressente 
com Cortés porque o capitão, em suas missivas e relatórios, carregava na tinta ao usar a primeira pessoa do singular, "olvidándose de los méritos de sus compañeros." De fato, é grande a quantidade de vezes que o cronista conta que o comandante consultava seus companheiros antes de tomar determinadas decisões. Além desse aspecto, ele aduz que o cronista "tenía la misma codicia" desenfrenada de todos sus compañeros, lo cual no disimula, pues la busca de riquezas [fue] uno de los móviles de la conquista." (IGLESIA, 1942, p.143)

As observações acerca dos primeiros dois cronistas não são menos instigantes do que o ethos discursivo que Cortés apresenta em suas cartas. Além de homem belicoso, ele é profícuo escritor. As relaciones, escritas em estágios diferentes, entre 1519 e 1521, chamam a atenção pelo volume e pela meticulosa descrição de batalhas, acordos e mortes... muitas mortes. Ora vemos um Cortés de estilo claro, conciso, objetivo, ora um minucioso observador dos chefes e dos locais dominados. Nas várias facetas que o discurso assume, parece predominar uma: o astuto, o inquieto; o belicoso e o ardiloso; enfim, transparece a figura de um homem impetuoso, movido pelo desejo constante de dominação. ${ }^{178} \mathrm{O}$ território discursivo em que se permite ver isso mais claramente é nos relatos de batalha, como os da terceira Carta, em que narra a entrada a Tenochtitlan. Nesse episódio expressa de maneira contundente um tiro disparado contra um índio. Também na última Relación, a travessia de pântanos e lagoas, rios, serras e penhascos projetam a imagem de uma façanha épica. Por fim, Cortés descreve também com forte objetividade as ordens, seja em períodos de ausência de batalhas, seja na organização de ataques.

Com efeito, as discussões do âmbito acadêmico-analítico expostas anteriormente auxiliam na compreensão das funções actanciais dessas personagens nas obras selecionadas.

Em Corona de fuego, a Malinche aparece em poucos momentos. Como já observamos, o foco de Usigli é a morte de Cuauhtémoc. Não obstante, cremos que a figura da indígena possui uma função das mais importantes para o desfecho da ação dramática.

\footnotetext{
177 Sobre o papel da codicia no processo de conquista, sugerimos a leitura de Amado Cervo, Contato entre civilizações: conquista e colonização espanholas da América (1975). Nesse estudo, o historiador brasileiro mostra que a ideia de serviço foi substituída pelo desejo de poder, glória e fama.

${ }^{178}$ Sobre as técnicas ficcionais de Cortés, a crítica espanhola Beatriz Pastor enfatiza a objetividade como a principal característica. Para ela, a ausência do elemento fantástico torna as Cartas um gênero literário bastante diferente do que se produzia à época. Por isso, ela entrevê "la creación de una serie de modelos ficcionales que aparecen subordinados a un proyecto de adquisición de fama, gloria y poder.” (1988, p. 146)
} 
É importante notar, a princípio, como as demais personagens a veem. O Coro de Mexicanos, por exemplo, a denomina "truchimán", pessoa astuta, sagaz, hábil, que atua de forma pouco escrupulosa ou pouco honrada. Essa expressão que reforçaria a imagem herdada das primeiras releituras da história está equalizada com o contexto histórico, uma vez que a peça foi escrita por volta de 1959, período em que o termo "malinchismo" acabara de emergir. (PAZ, 1994).

A designação negativa se transformará gradualmente, aos olhos dos Mexicanos, em ações. No segundo ato, durante as Festas, Cortés manda Doña Marina exigir de Cuauhtémoc que cesse os festejos, pois aquilo não seria algo digno de tão grandes senhores. Nesse caso, ela cumpre a função de porta-voz das ordens e mediadora das diferenças culturais entre os dois grupos. Ao receber o anúncio, Cuauhtémoc a insta a manifestar a própria opinião. Na réplica da mulher, revela-se uma relação servil:

CUAUHTÉMOC. - Di a Malinche, señora, que puesto que no gusta
de nuestro recogijo y de estas fiestas
y burlas, dejaremos de burlas
y hacer festejos, como hemos dejado
de esperar que pasen los malos sueños
que soñamos por hoy los mexicanos.
¿Sabes tú algo de eso?

DONA MARINA. - Señor rey, yo sólo sé que los días son siempre nuevos como los niños en los vientres longevos, y que Malinche es hoy quien da la ley.

(USIGLI, TCII, p. 812)

Demonstrando consciência dos acontecimentos e do tempo, Doña Marina aparece servindo a um novo senhor e não àquele cujo povo tivera domínio tempos atrás. ${ }^{179}$ Não se pode afirmar, porém, que essa resignação signifique aceitação nem apreço pela situação vivida. Nos momentos em que pode se expressar, as palavras da intérprete de Cortés estão mais propensas à consciência dos novos tempos e de seu lugar na história futura. Por isso, em alguns momentos do seu discurso brotam ambiguidades que demonstram não haver conformidade irrestrita nem vitimização. Isso fica claro nas cenas posteriores, principalmente no momento em que Mexicaltzinco lhe dá a notícia de que nos olhos de Cuauhtémoc resplandecia "el brillo del águila” e ela pondera o pressentimento de um ataque de sublevação:

\footnotetext{
${ }^{179}$ Víctor Grovas Hajj (2017) discute nessa peça a identidade e a alteridade mexicanas plasmadas nos momentos em que as personagens principais demonstram consciência de seu papel na história.
} 
Yo también, cuando miro pasar a las doncellas, siento que hay en mis ojos como un fulgor de estrellas, que soy la mejor y que en mi sangre está el estío.

Pero sólo son lágrimas esas estrellas. (USIGLI, TCII, p. 815)

Segundo a índia, o brilho nos olhos do senhor mexica não é de força, nem de luta ou de ataque, como interpreta o anão. Resplandece antes o medo, assim como nos olhos dela as lágrimas não denotam alegria por ter sido preterida.

Depois de dizer essas palavras, Cortés entra em cena e Doña Marina se retira.

No terceiro ato acontece a cena fundamental que permite ter mais clareza da atuação de Malinche no desfecho de Corona de fuego. Frente ao embate iminente - e à morte de Cuauhtémoc - Doña Marina é convocada por Cortés a confirmar o que sabe sobre a suposta emboscada contra os espanhóis:

\section{CORTÉS. - ¡Evasiva raza de astutos reptiles! Yo sé, sin embargo, desde antes del viaje, que ya conspirabais, y por eso os traje conmigo, exponiéndome a asechanzas viles. Di, Doña Marina, lo que tú sabías.}

(USIGLI, TCII, p. 827)

Seguem impropérios dirigidos por Coanacoch e outras personagens, questionando sua idoneidade no que diz respeito à expressão da verdade dos fatos, mas ela se defende: "soy de otro modo. / Soy la madre de un mundo que aún no llega". Continua argumentando que muitas vezes suas palavras, por meio da tradução, salvaram os indígenas da espada dos espanhóis. Reconhece saber "lo que es fundir dos mundos en mi sexo”. Por tudo isso, sua “traducción es fiel y declararé verdad.” (TCII, p. 828). Nessa fala, a articulação de "tradução" e "verdade" aponta para uma leitura diferente daquela que se começava a construir no início dos anos 60, ou seja, a de uma traidora. Em vez de confirmar que ela teria aceitado o invasor, a peça traz a visão de que a tradução, o uso da palavra, teria amenizado e evitado conflitos. Apesar de suas atitudes, o destino e a inevitabilidade histórica teriam sido mais fortes.

O peso que Malinche parece estar "condenada" a carregar se esclarece no julgamento de Cuauhtémoc. Uma vez encurralada entre a acusação dos indígenas e a autoridade de Cortés, sua réplica final dada a Cuauhtémoc impõe a consciência do reconhecimento que a história lhe concederá como conciliadora de dois mundos. Assim, 
assumindo de vez a própria voz após várias personagens tomarem a palavra em seu lugar, declara:

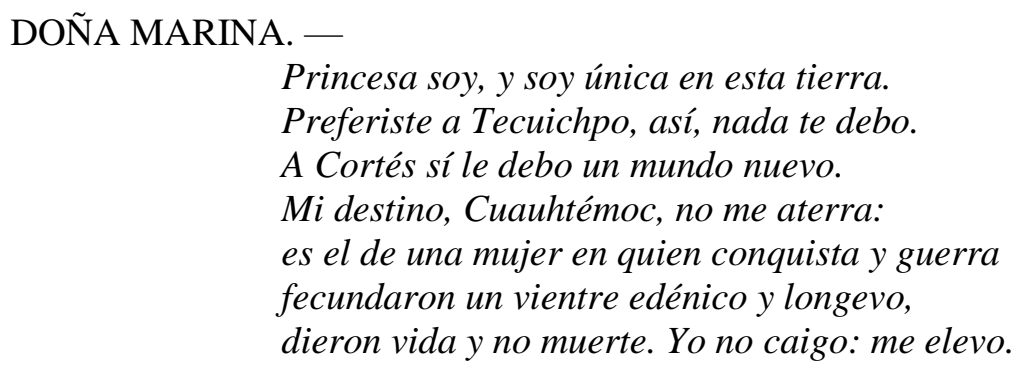

(TCII, p. 837)

As palavras de Doña Marina anunciam uma personagem para a qual confluem um mundo anterior e outro posterior à Conquista. Com efeito, os trechos apresentados acima colocam no centro do debate o quanto sua participação direta ou indireta contribuiu para que Cortés decidisse enforcar Cuauhtémoc. Usigli poderia ter atribuído à índia a confissão que seria determinante para a morte. No entanto, escolhe manter a ambiguidade e a dúvida que pairam na historiografia e no inconsciente coletivo - tal qual realiza sobre o milagre da Virgem de Guadalupe em Corona de luz. Se sua atuação como "língua" foi de extrema importância no processo de conquista, não parece ter sido essa a relação que ele enfatizou. Optou por situá-los em um interregno de tanta opressão que a teria feito sucumbir aos fatos.

Do ponto de vista cênico, a estratégia utilizada foi interpor falas de outras personagens no exato momento em que Malinche poderia ter proferido palavras de condenação ou salvação de Cuauhtémoc. Personagens de quem a historiografia pouco se ocupou (Juan Velázquez, Tapia, Temilotzin e o próprio Pax Bolón Acha) ganham voz na missão de oferecer subsídios para a decisão de Cortés. O interregno entre a enunciação de que diria a verdade e a afirmação de que seria elevada pela história certamente contribui para estender o suspense que decorre não do desconhecimento do desfecho, mas sim da possibilidade de se mostrar, no palco, "o que realmente aconteceu". Essa atmosfera de expectativa faz sentido, porque, conforme sabemos, também existem lacunas sobre a morte de Cuauhtémoc ${ }^{180}$. Podemos concluir que em Corona de fuego a

\footnotetext{
${ }^{180}$ Pensando nos efeitos de sentido que a delação de Doña Marina poderia gerar no espectador, vale a pena refletir sobre a criação da sensação de expectativa. O crítico português Pedro Barbosa (1982) destaca que a imprevisibilidade da mensagem teatral é uma das mais importantes marcas da teatralidade. Comparando o texto espetacular a um jogo de futebol e à travessia de um equilibrista na corda, afirma que "é justamente tal imprevisibilidade que justifica a emoção peculiar de expectativa sempre presente no espectador de teatro, e que do princípio ao fim, consciente ou inconscientemente, o absorve e o retém." (p. 68). Essa opinião poderia ser aplicada a um gênero de extração histórica? Seguramente, a incerteza que paira no imaginário
} 
relação de Hernán Cortés com a Malinche está marcada, na arquitetura cênica, pela expectativa de um desfecho confortante que daria ao espectador a certeza dos fatos desconhecidos da historiografia, e, no nível temático, pelo signo da servidão ao dominador e da resignação aos acontecimentos.

A imagem de uma Malinche que por meio da tradução concilia dois mundos está presente também em Águila de sol, de Sabina Berman. Em diversos momentos, ela faz a intermediação, sempre bem-intencionada, para unir os dois mundos. No quadro "Encontro", ela já está no barco que recebe os emissários de Moctezuma mandados a falar com a nau espanhola. Nesse momento, acontece o seguinte diálogo:

CORTÉS. - ¿Gato por liebre, sucios negros trajinantes? Mas cus-cus ¿io?: nueve de orozuz.

Los enviados han escuchado confundidos el idioma "extranjero" de Cortés. Malinche traduce:

MALINCHE. - Dice el Cortés: ¿no es una emboscada?

Los indios se miran extrañados entre sí. Colocan contra un mástil al cautivo teñido de greda. Ceremonialmente, le abren el pecho. Mientras extraen el corazón palpitante, los hispanos retroceden asqueados.

CORTÉS. — ¿What? ¡Azzcó! !Azzcó! (Desenvaina la espada:) !A los salvajes, mojigatos!

Cortés pasa el índice por la garganta, indicando así que deben ser asesinados los indios.

MALINCHE. - ¡Espera Cortés! No los mates. Te sacrificaban un hombre como si fueses un dios. (BERMAN, 1985, p. 234-236)

Nesse primeiro encontro, em referência explícita aos rituais astecas, a tradutora tem duas funções diferentes. No primeiro trecho, ela transpõe as palavras de Cortés. No segundo, mais do que isso, explica um código cultural para o conquistador. No quadro que relativiza as noções de civilização e barbárie é representativa sua intermediação justamente por reconhecer os códigos dos dois grupos e por isso impedir o ataque do comandante da expedição.

coletivo acerca da intervenção de Doña Marina no processo de conquista pode sim ser o motor da expectativa. Portanto, nesse ponto em especial, Rodolfo Usigli mostra habilidade e astúcia na criação teatral. 
Outra tentativa de harmonização se dá em uma cena marcadamente metateatral, como muitas de Águila o sol. No quadro "Batismos", Malinche tenta explicar os significados de símbolos cristãos a um grupo de indígenas. Ela está entre um padre e Cortés. Como signo teatral, o espaço que ela ocupa representa a posição de alguém que se coloca entre duas culturas: de um lado, como espectador, o mundo indígena; de outro, mostrando-se, o cristão. Na cena criada para traduzir o mistério da Santíssima Trindade, enquanto Malinche recita versículos do Gênesis sobre o pecado de Adão, o padre faz a voz de Deus. Por fim, fazendo voar uma pombinha de papel, a qual pousa em uma rosa, explica que: "Cristo es el Hijo, el Padre y el Espíritu Santo, tres personas en una. Esto es un misterio. Todo lo que les vengo contando son misterios." (p. 251). A capacidade de interpretar os signos do novo grupo social e a didática em transmiti-los sugerem que ela teria assimilado perfeitamente os códigos religiosos dos europeus.

A reflexão sobre a função que a "língua" teria exercido no processo de Conquista se completa pela exploração da linguagem. É por meio da modulação e estilização das falas que se caracteriza cada uma das personagens e, consequentemente, sua representação. Isso pode ser analisado a partir de uma parte do quadro "Los ojos de Cortés en los ojos de Moctezuma".

MOCTEZUMA. - iEs que ya he puesto mis ojos en tus ojos...! Hacía cinco días, diez días, estaba angustiado. Tenía fija la mirada en la Región del Misterio. Y tú has venido entre nubes, entre nieblas.

Como que esto es lo que habían dejado dicho los reyes, los que gobernaron antes tu ciudad: que habrías de regresar, que habrías de instalarte en tu asiento...

Pues ahora se ha realizado: ya llegaste. Con gran afán, con gran fatiga has llegado.

Ven y descansa: toma posesión de tus casas reales: de refrigerio a tu cuerpo.

¡Pásenle a su casa señores nuestros!

CORTES. - ¡Cuore mío! ¡Oh, cuore mío!

MALINCHE. - En verdad le amamos; intensamente le amamos.

CORTES. - ¿Pokarito? Paso. ¿Blof yo? Ve: cinco ases, digo cuatro, chécame las mangas.

MALINCHE. - Dice: ya estando en su casa podrán hablar en calma. Tengafe. (p. 255)

Vemos que a estilização da fala de Cortés, com vestígios de vários idiomas, de expressões prontas e formas arcaicas do castelhano, sublinha certa comicidade e ridicularização, mostrando-o estranho e extravagante naquele contexto. Já a linguagem de Moctezuma tem efeito contrário, porque seus turnos praticamente são reproduções dos 
registros de A visão dos vencidos. A composição de Malinche, por outro lado, lança mão de formas mais poéticas.

A refiguração dessas personagens através da modulação das linguagens leva à discussão acerca da interpretação que o tratamento ficcional pode conferir aos eventos históricos. Uma tendência da crítica que aborda o diálogo entre literatura e história é conferir à primeira capacidade inovadora porque ofereceria novas tramas e/ou pontos de vista. No caso de Águila o sol, identificamos que a fábula não é alterada. As representações de um Cortés violento e de uma Malinche conciliadora parecem advir de uma interpretação mais pautada pelo imaginário do que pelos registros históricos. Nesse sentido, a fidelidade ao texto compilado por León-Portilla para caracterizar Moctezuma poderia ser a ancoragem discursiva que abriria alternativas ao universo ficcional e não à história. Dessa forma, podemos concluir que nessa peça explora-se o modo de interpretação dos fatos históricos sem que, necessariamente, sejam oferecidas novas explicações do mesmo evento.

Se em Sabina Berman a exploração das falas é a forma de caracterizar as personagens e sua imagem no processo histórico, na peça de Leñero será a movimentação cênica a responsável por elevar exponencialmente tanto a dramaticidade quanto a ressignificação dos fatos. Por outro lado, a problemática da reelaboração pode ser mais bem analisada se comparamos a maneira como ele e Usigli trabalham as hesitações, as dúvidas e as angústias do capitão.

Em Corona de fuego, um aparte do conquistador revela indecisão sobre a execução de Cuauhtémoc. Dialogam com ele os Frailes e os coros de Mexicanos e de Espanhóis. Ao final, surge uma "Última Voz" que, por estar colocada entre parênteses, demonstra ser o inconsciente do conquistador.

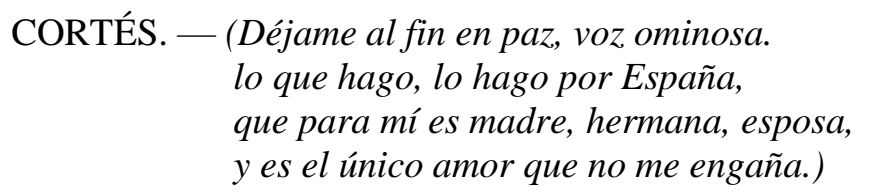

(USIGLI, TCII, p. 833)

A hesitação não tarda em desaparecer porque a consciência está pautada pela vontade de serviço à Espanha. Vemos um Cortés que acima das próprias virtudes se reconhece como integrante de uma forte nação. O resultado de suas reflexões é a certeza de que a melhor atitude será executar o líder indígena: 


\section{CORTÉS. - Serví a Dios y serví a mi monarca, y nada me reprocha mi conciencia si no es tener aún esta paciencia de oírte: mi poder todo lo abarca hasta el lodo que cunde de tu charca. Yo no conozco el miedo. Si apariencia de injusticia tuviera mi sentencia, mi faz mostrara del miedo la marca.}

(USIGLI, TCII, p. 835)

O Cortés já idoso e triste criado por Leñero é muito diferente. Logo no primeiro quadro, ordena que o Secretário escreva algumas palavras, as quais revelam o ressentimento de quem não está contente com o reconhecimento pífio que a história lhe atribui:

CORTÉS: ¡Silencio! (Pausa. Se concentra. Dicta:) Cortés tuvo que aprender por propia experiencia, que la gratitud de una corte es más en proporción a lo que se promete de lo futuro que a lo que ha recibido de lo pasado. Así que su posición era la de un litigante importuno, cuyas reclamaciones de tierras y encomiendas y títulos en la Nueva España, aunque justísimas, resultaban a la corte demasiado grandes para ser atendidas desde luego. (Pausa.) Un día, Cortés, no pudiendo tener audiencia del emperador Carlos V... (LEÑERO, TC II, p. 427).

Simulando a escrita de uma autobiografia, a retrospectiva representada por Leñero quer acentuar o esquecimento e/ou a falta de reconhecimento sentida pelo protagonista. Seu pesar possui tão grandes marcas que, conforme vimos no tópico anterior, chega ao limite de criar fatos ou mentir sobre eles:

SECRETARIO: (Interrumpiendo, pero sin dejar de teclear): ¿No nos recibió el emperador?

CORTÉS: ¡Escribe!... (Reanuda.) No pudiendo tener audiencia del emperador, Cortés se abrió camino por entre la multitud que rodeaba la carroza del monarca, y subió al estribo. Y que preguntando Carlos $V$ quién era aquel hombre, Cortés replicó: "El que os ha dado más reinos que ciudades os dejaron vuestros padres".

$[\ldots]$

SECRETARIO: ¿Así dijimos al emperador?

CORTÉS: No seas imbécil, Pancho. ¡Cuándo vas a entender! Nosotros no relatamos incidentes, nosotros escribimos la verdad histórica. (p. 427)

No que diz respeito à sua relação com a Malinche, o Cortés de Vicente Leñero interage menos com ela. Apesar disso, Malintzin (o dramaturgo a nomeia dessa forma) compõe o grupo de personagens espectrais do conquistador e está presente em quase todos 
os quadros. O fato de estar sempre à espreita do protagonista nos levaria a pensar inclusive na existência de uma ação dramática secundária: a vingança de Malinche. Todavia, tal como na peça de Usigli, a mulher indígena tem função preponderante para o desfecho da ação principal.

Esse aspecto está emoldurado pela cena em que mais de uma vez o capitão comete violações. Após derrubar o ídolo, todo seu fulgor e euforia se direcionam à sua tradutora. Cortés a estupra e complementa a violência física com a verbal: “¿Cómo aprendiste nuestra lengua?... ¿Así? ¿Follando con los soldados? (Sonríe.) No lo haces mal, ¿eh? Nada mal.” (LEÑERO, TCII, p. 456). As constantes e sucessivas violações motivam a vingança de Malintzin na mesma proporção da violência sofrida. Na volta a Cempoala, "cuando Cortés está a punto de derribar [nuevamente] el monolito, Malintzin levanta su lanza como una señal guerrera, y grita. / MALINTZIN: ¡Teúles, noooooo! ¡Noooo! !Teúles, no!’” (TCII, p. 473).

Essa movimentação se alinha ao fato de Malintzin observar Cortés constantemente. Ela estava à espreita. Com efeito, o grito que nega ao espanhol a condição de teúl (deus) afasta-se do relato histórico para oferecer uma postura não mais de reflexão sobre a história, mas sim de engajamento e luta contra um imaginário que atribuiria ao passado as raízes de problemas do presente, tais como a ausência do exercício da democracia e a dependência política e econômica. Nesse sentido, a história não deve ser valorizada como reconhecimento; o que deve ser feito é a eliminação dos efeitos do trauma. Por isso, frente ao conquistador fragilizado pelas flechadas recebidas, Malintzin "empeña al secretario que se encuentra arrodillado frente a Cortés [...] eleva su lanza y luego la clava, con fuerza, con odio, sobre el pecho de Cortés". (TCII, p. 474). 


\section{Considerações finais}

Ao longo deste trabalho analisamos as transformações estéticas da dramaturgia mexicana promovidas por autores que se debruçaram sobre a história. A questão primordial reivindicava compreender se o diálogo entre o ficcional e a historiografia era um procedimento constante ou esporádico dentro de um período relativamente extenso situado entre os anos pós-revolucionários até o início da pósmodernidade.

Partindo, então, de um caso emblemático, como o de Rodolfo Usigli, verificamos que ele não foi o único autor de seu tempo a trabalhar com temas históricos. Por outro lado, inserindo-o em seu contexto, vemo-lo tornar-se o principal dramaturgo de seu tempo devido à sua capacidade de articular os episódios históricos com o presente. Cercado por uma mentalidade nacionalista determinada ora pelo Estado ora por ensaios de interpretação da identidade, ele não se submeteu a fazer teatro em função de interesses do poder político. Procurou sempre apreender, nos eventos históricos que representava, a "verdade dramática". Para ele, isso significava ater-se às necessidades da representação.

$\mathrm{O}$ rigor estético de Usigli e a mentalidade nacionalista que pairava no imaginário dos anos pós-revolucionários permitiu-nos atribuir à maneira como ele encarava a história a expressão "a história descoberta". Em nossa perspectiva, essa nomenclatura designa a expressão, em todas as obras anti-históricas (e mesmo em $E l$ gesticulador), da vontade de fazer com que se conhecesse a "verdade" histórica. Estamos convencidos, pelos resultados, de que Usigli não pretendia mostrar outra visão dos fatos nem negar os eventos sobre os quais escreveu. Se promovia incongruências com os documentos era por sua fidelidade à unidade de ação dramática. Se criticava a Revolução, não era porque duvidasse de seus fundamentos, mas de suas consequências e aproveitamentos. Portanto, descobrir a história era o procedimento mais adequado para a construção nacional, ideal perseguido por muitos intelectuais contemporâneos a ele.

Do ponto de vista formal, a presença de personagens incumbidas na escrita da história (historiadores no sentido mais amplo da palavra) proporcionou utilizar recursos de metateatralidade. Nesse ponto, observamos uma sedimentação peculiar entre o conteúdo (as mentiras políticas e a manipulação de certo viés historiográfico) e a forma (criação de expectativa, omissão / revelação de fatos e criação de situações de teatro dentro do teatro). 
No caso de Vicente Leñero, a história é vivida como algo a se construir e não a ser descoberto. Tendo se dedicado à dramaturgia a partir de um contexto em que as certezas oriundas do passado e os ideais do presente se haviam desvanecido, encontra na simultaneidade de espaços e na reescrita de documentos a chave de sua concepção cênica. Partindo dos ensinamentos do Teatro Político de Weiss e Piscator, eleva os recursos a um patamar diferenciado ao se preocupar com temas especificamente marcantes da história mexicana, até chegar à proposta mais ousada: a não aceitação dos fatos históricos.

Sabina Berman, partindo de preocupações feministas, também apresenta etapas diferentes em sua dramaturgia. Se as primeiras obras recorriam a eventos consagrados pela historiografia, os quais eram apresentados em cenas rápidas, diálogos curtos e algumas estratégias épicas; ela passa com o tempo a investigar estruturas e figurações de uma história que se aproxima mais do imaginário, do folclórico, da curiosidade e do lendário do que de um conhecimento vivenciado ou aprendido. O recurso de levar ao palco referentes históricos se pauta, então, pela negação dessa maneira pouco rigorosa de conhecer a história e por isso passível de ser ressignificada.

As diferentes perspectivas sobre a história obedecem, de certa forma, ao próprio movimento intelectual que dominou essa área das ciências humanas ao longo do século XX. Porém, a pesquisa revelou que a permanência do entrecruzamento com a história foi peculiar nesse período, pois dois aspectos se sobressaíram. O primeiro correspondia às particularidades da cultura mexicana e sua relação com a história. Conforme vimos, não foram inexpressivas as tentativas de vincular a história ao nacionalismo, à identidade nacional e à filosofia. Por outro lado, o sistema de oficinas de escrita proporcionou a continuidade de certa maneira de se fazer dramaturgia. Por causa dessa particularidade do sistema literário, ou seja, a transmissão formal de procedimentos escriturais, a sucessão geracional não se manifestou pela negação crítica, mas sim pela aglutinação dos conceitos tradicionais às novidades. Mesmo os recursos "importados" (as formas do teatro épico ou do absurdo) foram adaptados às estratégias de representação de elementos históricos.

Essas constatações foram possíveis porque estabelecemos um movimento analítico pendular. Tomamos inicialmente os dramaturgos em sua peculiaridade e historicidade, apontando ao mesmo tempo os acontecimentos relevantes de sua época e as perspectivas com que os intelectuais e a cultura acadêmica interpretavam a história. Assim, o cotejo das representações dramáticas de elementos históricos (personagens, espaços e eventos) com a interpretação historiográfica acadêmica contribuiu 
sobremaneira para a constatação de certas características do sistema dramatúrgico mexicano.

Passamos então a confrontar as estratégias utilizadas na reelaboração de um evento comum, a Conquista do México. Essa análise que se desenvolveu no último capítulo possibilitou-nos, enfim, verificar como a dramaturgia do século $\mathrm{XX}$ foi transformando-se ao mesmo tempo em que esse evento era reelaborado.

Em síntese, podemos dizer que no sistema dramatúrgico mexicano parece existir a necessidade de encontrar uma linguagem dramática capaz de dar conta das novas formas de pensar e experimentar os acontecimentos passados. Da grandiloquência trágica escolhida por Rodolfo Usigli como forma capaz de representar o esplendor do evento e das personagens nele envolvidas, passou-se comicamente, pela rapidez proporcionada pelos quadros, à sobreposição das categorias de espaço e tempo, acentuando-se a violência e a necessidade de matar, simbolicamente, uma forma de sentir o pretérito. 


\section{Referências}

ABEL, Lionel. Metateatro: uma visão nova da forma dramática. Trad. Bárbara Heliodora. Rio de Janeiro: Zahar, 1968.

ADAME, Domingo. Teatros y teatralidades en México: siglo XX. Xalapa: Universidad Veracruzana, 2004.

AGUILAR CAMÍN, Hector, MEYER, Lorenzo. A la sombra de la revolución mexicana. México DF: Cal y Arena, 2009.

ALCÁNTARA MEJÍA, José Ramón. Textralidad: textualidad y teatralidad en México. México DF: Universidad Iberoamericana, 2010.

ANDERSON, Benedict. Comunidades imaginadas: reflexões sobre a origem e a difusão do nacionalismo. Trad. Denise Bottman. São Paulo: Companhia das Letras, 2008.

A’NESS, Francine. Diálogos con Sabina Berman. In: BIXLER, Jacqueline E. (Comp.). Sediciosas seducciones: sexo, poder y palabras en el teatro de Sabina Berman. México DF: Escenología, 2004, p. 43-63.

ARACIL VARÓN, Beatriz. Teatro evangelizador y poder colonial en México. Destiempos: revista de curiosidad cultural, México DF, v. 14, ano 3, p. 220-234, mar./abr. 2008. Disponível em: <http://www.destiempos.com/archivo1.htm>. Acesso em: 21 jul. 2016.

ARENDT, Hannah. O Conceito de História - Antigo e Moderno. In: Entre o passado e o futuro. Trad. Mauro W. Barbosa. 7.ed. São Paulo: Perspectiva, 2011, p. 69-126.

ARIZMENDI, Martha Elia, et al. Morelos: ¿un mito desmitificado? una lectura del Martirio de Morelos desde la posmodernidad. Contribuciones desde Coatepec, Toluca, Universidad Autónoma del Estado de México, n. 22, jan./jun., p. 11-25, 2002. Disponível em: <http://revistacoatepec.uaemex.mx/article/view/271/264>. Acesso em: 28 out. 2016.

BARTHES, Roland. O efeito de real. In: O rumor da língua. Trad. Mario Laranjeira. São Paulo: Martins Fontes, 2004, p. 181-190.

BASTOS, Alcmeno. Introdução ao romance histórico. Rio de Janeiro: EdUERJ, 2007.

BAUMAN, Zygmunt. Medo líquido. Trad. Carlos Alberto Medeiros. Rio de Janeiro: Jorge Zahar, 2008.

BEARDSELL, Peter R. Teatro para caníbales: Rodolfo Usigli y el teatro mexicano. Bueno Aires / México DF: Siglo XXI, 2002.

Los niveles de la verdad en Corona de luz de Rodolfo Usigli. Anales de literatura hispanoamericana, n. 12. Madri: Universidade Complutense de Madri, 1983, p. 13-27. Disponível em: < http://www.cervantesvirtual.com/nd/ark:/59851/bmcn60b6>. Disponível em: 08 set. 2015. 
BERMAN, Sabina. Águila o sol. In: Teatro de Sabina Berman. México DF: Mexicanos Unidos, 1985, p. 224-265. 267-325.

La grieta. In: Puro Teatro. México DF: Fondo de Cultura Económica, 2004, p.

Hugo Argüelles: la dramaturgia como el arte de la acción. In: VV.AA. Hugo Argüelles: estilo y dramaturgia. Seleção e notas Edgar Ceballos. México DF: INBA / Gaceta, 1994, p. 597-687.

BISSETT, Judith I. Constructing alternative version: Vicente Leñero's documentary and historical drama. Latin American Theater Review, Kansas: Universidade do Kansas, v. 18, n. $1, \quad$ p. 71-78, $1985 . \quad$ Disponível em: <https://journals.ku.edu/index.php/latr/issue/view/77>. Acesso em: 10 nov. 2014.

BIXLER, Jacqueline E. (Comp.). Sediciosas seducciones: sexo, poder y palabras en el teatro de Sabina Berman. México DF: Escenología, 2004.

The postmodernization of History in the theater of Sabina Berman. Latin American Theater Review, Kansas: Universidade do Kansas, v. 30, n. 2, p. 45-60, 1997. Disponível em: < https://journals.ku.edu/latr/article/view/1157>. Acesso em: 1 out. 2017.

BONFIL BATALLA, Guillermo. México profundo: una civilización negada. México DF: De Bolsillo, 2010.

BRADING, David. Los orígenes del nacionalismo mexicano. 2.ed. Trad. Soledad Loreza. México DF: Era, 1991.

Patriotismo y nacionalismo en la historia de México. In: Congreso de la Asociación Internacional de Hispanistas, 12, 1995, Birmingham. Actas... Birmingham: s/e, 1998, p. 1-18. $\quad$ pisponível em: <https://dialnet.unirioja.es/servlet/articulo?codigo=2317256>. Acesso em: 25 abr. 2015.

Octavio Paz y la poética de la historia mexicana. Trad. Antonio Saborit. México DF: Fondo de Cultura Económica, 2002.

BRECHT, Bertolt. Estudos sobre teatro. Trad. Fiama Pais Brandão. Rio de Janeiro: Nova Fronteira, 2005.

BURGESS, Ronald D. El nuevo teatro mexicano y la generación perida. Latin American Theater Review, Kansas: Universidade de Kansas, v. 18, n. 2, p. 93-99. 1985. Disponível em: <https://journals.ku.edu/latr/issue/view/77>. Acesso em: 26 jun. 2016.

. The new dramatists of Mexico, 1967 - 1985. Lexington: University Press of Kentucky, 1991.

CAILLET-BOIS, Julio. Bernal Díaz del Castillo, o de la verdad de la historia. Revista Iberoamericana, v. XXV, n. 50, p. 199-228, jul./dez. 1960. Disponível em: $<$ http://revista- 
iberoamericana.pitt.edu/ojs/index.php/Iberoamericana/article/view/1980/2175>. Acesso em: 10 jul. 2016.

CAMPESINO, Juan. Unas palabras sobre Ibargüengoitia, el teatro y la historia. Paso de Gato, abr./maio/jun., p. 45-47, 2010.

CANDIDO, Antonio. Introdução. In: Formação da literatura brasileira: momentos decisivos. 6.ed. Belo Horizonte: Itatiaia, 2000a, p. 23-37.

Literatura e sociedade: estudos de teoria e história literária. 8.ed. São Paulo: T.A. Queiroz, 2000b.

De cortiço a cortiço. In: O discurso e a cidade. São Paulo: Duas Cidades, 1993, p. $123-152$.

CARTY, Roberto Ransom (Coord.) Antología de ensayos teatrales (Análisis, críticas, teoría, pedagogía y puesta en escena). Chihuahua: Universida Autónoma de Chiuaua, 2013.

CASAS DE USIGLI, Argentina. El gesticulador, pieza para demagogos. In: Mi vida con Rodolfo Usigli. Alicante: Biblioteca Virtual Miguel de Cervantes, 2014. Disponível em: $<$ http://www.cervantesvirtual.com/obra/mi-vida-con-rodolfo-usigli/>. Acesso em: 25. jul. 2016.

CEBALLOS, Edgar. La influencia de Brecht en la escena mexicana en el centenario de su natalicio, Assaig de teatre: revista de l'Associació d'Investigació i Experimentació Teatral, Barcelona: Universidade de Barcelona, n. 35, p. 29-44, 2002. Disponível em: < http://www.raco.cat/index.php/AssaigTeatre/article/view/145798>. Acesso em: 28 jan. 2018.

CERTEAU, Michel de. A escrita da história. Trad. Maria de Lourdes Menezes. Rio de Janeiro: Forense-Universitária, 1982.

CERVO, Amado. Contato entre civilizações: conquista e colonização espanholas da América. São Paulo: McGraw-Hill do Brasil, 1975.

CORTEZ, Hernan. A conquista do México. Trad. Jurandir Soares dos Santos: Porto Alegre: L\&PM, 1986.

COSÍO VILLEGAS, Daniel. EI sistema político mexicano: las posibilidades de cambio. 5.ed. México DF: Joaquín Mortiz, 1974.

Cuitláhuac Chávez, B.A. La figura mítica de Pancho Villa como ícono de identidad nacional y masculinidad en México y en la frontera México-Estados Unidos a través de la literatura y el cine. 2013. Tese (Doutorado) — Universidade do Texas, Austin, 2013.

CYPESS, Sandra Messinger. La Malinche in the Mexican Literature: from history to myth. Austin: University of Texas, 1991. 
DAY, Stuart A. Berman's Pancho Villa and neoliberal desire. Latin American Theater Review, Kansas: Universidade do Kansas, v. 33, n.1, p. 5-23, 1999. Disponível em: < https://journals.ku.edu/latr/issue/view/106>. Acesso em: 12 ago. 2016.

DE LA CONCHA, Manuel. Parte detallado, rendido por el jefe realista Manuel de la Concha al virrey Calleja, sobre la acción de Temalaca, en la que don José María Morelos fue derrotado y hecho prisionero. Disponível em: <http://www.biblioteca.tv/artman2/publish/1815_110/Parte_detallado_rendido_por_el_j efe_realista_Manuel_de_la_Concha_al_virrey_Calleja_sobre_la_acci_n_de_Temalaca_ en_la_que_don_Jos_Mar_a_Morelos_fue_derrotado_y_hecho_prisionero.shtml >.

Acesso em: 30 maio 2018.

DE MARÍA Y CAMPOS, Armando. "Corona de fuego de Rodolfo Usigli, en el teatro Xola", en Novedades, 15 septiembre 1961. Reseña histórica del teatro mexicano, CITRU. Disponível em: <http://resenahistoricateatromexico2021.net/proyecto_default.php?id=1687\&op=1\&text o_palabra=rodolfo\%20usigli >. Acesso em: 3 mar. 2017.

"Corona de fuego, discutida pieza de Rodolfo Usigli. II", en Novedades, 27 septiembre 1961. Reseña histórica del teatro mexicano, CITRU. Disponível em: $<$ http://resenahistoricateatromexico2021.net/proyecto_default.php?id=1689\&op=1\&text o_palabra=rodolfo\%20usigli >. Acesso em: 3 mar. 2017.

DERRIDA, Jacques. O cinema e seus fantasmas. Trad. Marcelo Ribeiro. Incinerrante, 2014. Disponível em: <https://www.incinerrante.com/textos/jacques-derrida-e-osfantasmas-do-cinema>. Acesso em: 17 dez. 2016.

DÍAZ DEL CASTILLO, Bernal. Historia verdadera de la conquista de la Nueva España. Tomo II. México DF: Porrúa, 1977.

DIPUCCIO, Denise M. Metatheorical histories in Corona de luz. Latin American Theater Review, Kansas: Universidade do Kansas, v. 20, n. 1, p. 26-36 1986. Disponível em <https://journals.ku.edu/index.php/latr/article/view/662/637>. Acesso em 9 abr. 2015.

ÉSQUILO. Prometeu acorrentado. In. SÓFOCLES e ÉSQUILO. Rei Édipo. Antígone. Prometeu acorrentado. Prefácio, introdução e notas de J. B. Mello e Souza. Rio de Janeiro: Ediouro, s/d.

ESTEVES, Antonio Soares. O romance histórico brasileiro contemporâneo (19752000). São Paulo: UNESP, 2010.

FLORESCANO, Enrique. Un conflicto de hoy y del futuro: las relaciones entre las etnias, el Estado y la nación en México. In: LABASTIDA, Julio, CARMON, Antonio (Coord.). Globalización, identidad y democracia. México DF: Siglo XXI Editores, 2001, p. 394405 .

Notas sobre las relaciones entre memoria y nación en la historiografía mexicana. Historia Mexicana, México DF: El Colegio de México, v. 53, n. 2, p. 391-416, out./dez. 2003. Disponível em:<http://www.jstor.org/stable/25139503>. Acesso em: 25 abr. 2015. 
El nuevo pasado mexicano. México DF: Cal y Arena, 2009.

FREIRE, Silka. Teatro documental latinoamericano: el referente histórico y su (re) escritura dramática. La Plata: Al Margen, 2007.

GALICIA, Rocío. La dramaturgia actual del norte de México. In: SÁENZ FIERRO, Rosa María. (Coord.) Teatro del norte / teatro de frontera: antología de ensayos y ponencias. Chiuaua: Universidad Autónoma de Chihuahua, 2012, p. 13-36

GARCÍA ICAZBALCETA, Joaquín. Documentos para la historia de México. Tomo II. México DF: Francisco Díaz de León, 1889. Disponível em: < http://cdigital.dgb.uanl.mx/la/1080023894_C/1080024002_T2/1080024002_MA.PDF>. Acesso em: 10 dez. 2016.

GELLNER, Ernest. Nações e nacionalismo. Trad. Inês Vaz Pinto. Lisboa: Gradiva, 1993.

GIMÉNEZ MONTIEL, Gilberto. La controversia ideológica en torno al VI Informe de José López Portillo. Ensayo de análisis argumentativo. Revista Mexicana de Sociología, Universidad Autónoma de México, v. 45, n. 2, abr./ jun., 1983, p. 507-544. Disponível em: <http://www.jstor.org/stable/3540259>. Acesso em: 20 set. 2016.

GLANTZ, Margo. Las hijas de la Malinche. Debate feminista, México DF: Universidade Nacional Autônoma de México, v. 6, ano 3, set. 1992. Disponível em: $<$ http://www.debatefeminista.com/articulos.php?id_articulo=1053\&id_volumen=39>. Acesso em: 18 jul. 2014.

Doña Marina y el capitán Malinche. In: La Malinche, sus padres y sus hijos. Méxido D.F.: Taurus, 2001, p. 115-133. Disponível em:

$<$ http://www.cervantesvirtual.com/portales/margo_glantz/obra/doa-marina-y-el-capitnmalinche-0/>. Acesso em: 20 maio 2017.

"Anécdotas y recuento". Revista de la Universidad de México: Nueva época, México D.F.: Universidad Nacional Autónoma de México., n. 45, p. 12-16, nov. 2007. Disponível em: <http://www.revistadelauniversidad.unam.mx/45/glantz/45glantz.html>. Acesso em: 19 abr. 2018.

GOBBI, Márcia Valéria Zamboni. Relações entre ficção e história: uma breve revisão teórica. Itinerários, Araraquara: Unesp, n. 22, p. 37-57, 2004. Disponível em: < http://seer.fclar.unesp.br/itinerarios/article/view/2736/2473>. Acesso em: 16 jan. 2014.

GRILLO, Rosa María. El mito de un nombre: Malinche, Malinalli, Malintzin.

Mitologías hoy, Barcelona: Universidade Autônoma de Barcelona, n. 4, p. 15-26, 2011. Disponível em: <http://revistes.uab.cat/mitologias/article/viewFile/v4-grillo/15>.

Acesso em: 20 maio 2014.

GROVAS HAJJ, Víctor. Usigli y la confrontación histórica con el Otro en la Conquista: "Corona de fuego". In: Biblioteca Virtual Miguel de Cervantes. Alicante: Centro Virtual Cervantes, 2017. Disponível em:

<http://www.cervantesvirtual.com/nd/ark:/59851/bmc7q109>. Acesso em 06 jun. 2018. 
HAMBURGER, Käte. A lógica da criação literária. Trad. Margot P. Malnic 2.ed. São Paulo: Perspectiva, 1986.

HASMANN, Robson Batista dos Santos. Do Paraíso à solidão: modernidade em La hija de Rappaccini, de Octavio Paz. São Paulo, 2013. 140f. Dissertação (Mestrado em Letras) - Faculdade de Filosofia, Letras e Ciência Humanas, Universidade de São Paulo.

HOBSBAWM, Eric J. Nações e nacionalismo desde 1780: programa, mito e realidade. Trad. Maria Célia Paoli e Anna Maria Quirino. 4.ed. São Paulo: Paz e Terra, 2004.

HOLZAPFEL, Tamara. Pueblo rechazado: educating the public through reportage. Latin American Theater Review, Kansas: Universidade de Kansas, v. 10, n. 1, p. 15-21, 1976. Disponível em: < https://journals.ku.edu/latr/article/view/254/229 >. Acesso em: 15. dez. 2016.

HOSIASSON, Laura Janina. Nação e imaginação na guerra do Pacífico. São Paulo: Edusp, 2011.

HURTADO, Guillermo. El hiperión y su tiempo. In: Enciclopedia electrónica de la filosofía mexicana. Centro de documentación en filosofía latinoamaricana e ibérica, Universidad Autónoma Metropolitana, Iztapalapa. Disponível: <http://dcsh.izt.uam.mx/cen_doc/cefilibe/index.php/encic-dic-corrientes>. Acesso em: 26 jul. 2016.

HUTCHEON, Linda. Poética do pós-modernismo: história, teoria, ficção. Trad. Ricardo Cruz. Rio de Janeiro: Imago, 1991.

IBARGÜENGOITIA, Jorge. El libro de oro del teatro mexicano. 2.ed. Seleção, introdução e notas de Luis Mario Moncada. México DF: Universidade Autônoma Metropolitana, 2011.

IGLESIA, Ramón. Cronistas e historiadores de la Conquista de México: el ciclo de Cortés. México DF: Colegio de México, 1942.

ITA, Fernando de. La paradoja de los 80's: una visión particular del teatro en México. Latin American Theatre Review, Kansas: Universidade do Kansas, v. 25, n. 22, p. 113-122, 1992. Disponível em:

<https://ojsprdap.vm.ku.edu/index.php/latr/article/viewFile/928/903>. Acesso em: 10 dez. 2013.

JAMESON, Fredreric. O romance histórico ainda é possível? Trad. Hugo Mader. Novos Estudos - CEBRAP, São Paulo, n. 77, p.185-203, mar. 2007. Disponível em: <http://www.scielo.br/pdf/nec/n77/a09n77.pdf>. Acesso em: 9 set. 2017.

KARNAL, Leandro. O teatro da fé: representação religiosa no Brasil e no México do século XVI. São Paulo: Hucitec, 1998.

KOSELLECK, Reinhart. Futuro pasado: para una semántica de los tiempos históricos. Buenos Aires: Paidós, 1993. 
KRAUZE, Enrique. Caudillos culturales en la Revolución mexicana. México DF: Tusquets, 2014.

LACOUTURE, Jean. A história imediata. In: LE GOFF, Jacques. A História Nova. 4.ed. Trad. Eduardo Brandão. São Paulo: Martins Fontes, 2001, p. 215-240.

LAFAYE, Jacques. Quetzalcóatl y Guadalupe: la formación de la conciencia nacional en México. 2.ed. Trad. Ida Vitale y Fulgencio López Vidarte. México DF: Fondo de Cultura Económica, 1992.

LE GOFF, Jacques. História e memória. 2.ed. Trad. Bernardo Leitão et al. Campinas: UNICAMP, 1992.

LEHMANN, Hans-Thies. Teatro pós-dramático. Trad. Pedro Süssekind. São Paulo: Cosac \& Naify, 2007.

LEÑERO, Vicente. Introdução. In: La nueva dramaturgia mexicana. Seleção e introdução Vicente Leñero. México DF: El Milagro, 1996, p. 9-39.

Vivir del teatro. México DF: Fondo de Cultura Económica, 2012.

Pueblo rechazado. In: Teatro completo I. México DF: Fondo de Cultura Económica, 2008, p. 9-47.

Martirio de Morelos. In: Teatro completo II. México DF: Fondo de Cultura Económica, 2008, p. 543-619.

La noche de Hernán Cortés. In: Teatro completo II. México DF: Fondo de Cultura Económica, 2008, p. 421-478.

LEÓN-PORTILLA, Miguel. A visão dos vencidos: a tragédia da conquista narrada pelos astecas. Porto Alegre: L\&PM, 1987.

De la oralidad a los códices a la "Historia General": trasvase y estructuración de textos allegados por fray Bernardino de Sahagún. Estudios de cultura náhuatl, México, n. 29, p. 65-141, 1999. Disponível em: < http://www.historicas.unam.mx/publicaciones/revistas/nahuatl/pdf/ecn29/ecn029.html>. Acesso em: 10 jul. 2016.

LESKY, Albin. A tragédia grega. 4.ed. São Paulo: Perspectiva, 2003.

LÓPEZ AUSTIN, Alfredo. Estudio acerca del método de investigación de fray

Bernardino de Sahagún. Estudios de cultura náhuatl, México DF, v. 42, p. 353-

400, ago. 2011. Disponível em:

<http://www.scielo.org.mx/scielo.php?script=sci_arttext\&pid=S0071-

16752011000100018\&lng=es\&nrm=iso>. Acesso em: 10 jul. 2016.

LISS, Peggy K. Orígenes de la nacionalidad mexicana, 1521-1556. La formación de una nueva sociedad. Trad. Agustín Bárcena. México DF: Fondo de Cultura Económica, 1986. 
LUKÁCS, György. O romance histórico. Trad. Rubens Enderle. São Paulo: Boitempo, 2011.

MACHADO, Luís Cláudio. Da imagem à ação ou da falência do olhar: estudo das rubricas na peça Roberto Zucco de Bernard-Marie Koltès. Revista Sala Preta, São Paulo: Escola de Comunicação e Artes/USP, v. 1, n. 1, p.35-48, 2001. Disponível em: < http://www.revistas.usp.br/salapreta/issue/view/4682/showToc >. Acesso em: 30 jan. 2017.

MAESTRO, Jesús G. Cervantes y Shakespeare: el nacimiento de la literatura metateatral. In: ROBBINS, Jeremy, WILlIAMSON, Edwin (Eds.). Bulletín of Spanish Studies: Essays in Memory of E. C. Riley on the Quatercentenary of Don Quijote, v. 81, n. 4-5, p. 599-612, 2004.

MAGNARELLI, Sharon. Tea for two: performing history and desire in Sabina Berman's Entre Villa y una mujer desnuda. Latin American Theater Review, Kansas: Universidade do Kansas, v. 30, n. 1, p. 55-74, 1996. Disponível em: <https://journals.ku.edu/latr/issue/view/100>. Acesso em: 8 maio 2016.

MARCO, Valéria de. A perda das ilusões: o romance histórico de José de Alencar. Campinas: Unicamp, 1993.

MÁRMOL, José. Amalia. 2V. Buenos Aires: Kapelusz, 1968.

MARTÍNEZ, José Luis. Fray Bernardino de Sahagún y sus informantes indígenas. Vida y obra. In: SAHAGÚN, Bernardino de. El México antiguo. Caracas: Biblioteca Ayacucho, s/d, p. IX - CII.

MARTÍNEZ DE OLCOZ, Nieves. Águila o sol de Sabina Berman: archivo, memoria y re-escritura. Teatro: Revista de Estudios Culturales, n. 11, p. 219-234, jun. 1997. Disponível em: <http://digitalcommons.conncoll.edu/teatro>. Acesso em: 24 nov. 2013.

MARTINS, Maria Helena Pires. Proposta de classificação do gesto no teatro. In: GUINSBURG, J., COELHO NETTO, J. Teixeira, CARDOSO, Reni Chaves. Semiologia do teatro. 2.ed. São Paulo: Perspectiva, 1988, p. 249-262.

MAYORGA, Juan. El dramaturgo como historiador. Paso de Gato, n. 41, abr./maio/jun., p. 32-37, 2010.

MENTON, Seymour. La nueva novela histórica de la América Latina 1979-1992. México DF: Fondo de Cultura Económica, 1993.

MOTTA, Romilda Costa. Práticas políticas e representações de si: os escritos autobiográficos da mexicana Antonieta Rivas Mercado e da brasileira Patrícia Galvão (Pagu). Tese (Doutorado) — Faculdade de Filosofia, Letras e Ciências Humanas. Universidade de São Paulo, São Paulo, 2014.

MOTOLINÍA, Fray Toribío de Benavente. Carta al Emperador Carlos V. In: GARCÍA IZCALBACETA, Joaquín. Colección de documentos para la historia de México. 
Tomo Primeiro. México D.F.: Porrúa, 1980. Disponível em: $<$ http://www.cervantesvirtual.com/obra/coleccion-de-documentos-para-la-historia-demexicotomo-primero--0/> . Acesso em: 30 maio 2018.

NIETZSCHE, Federico. De la utilidad de los estudios históricos. In: Obras completas de Federido Nietzsche: Consideraciones intempestivas 1873 - 1875. Tradução, Introdução e notas Eduardo Ovejero y Maury. Vol. II. Madrid / Buenos Aires / México: Aguilar, 1949, p. 85-169.

ORTIZ BULLÉ-GOYRI, Alejandro. Orígenes y desarrollo del teatro de revista en México (1869-1953). In: OLGUÍN, David. (coord.). Un siglo de teatro en México. México DF: FCE/Conaculta, 2011, p. 40-53.

El gesticulador para gesticuladores: entre el escenario y la pantalla, Investigación Teatral, Xalapa: Universidade Veracruzana, v. 2, n. 3, 2012, p. 7-22. Disponível em:

http://revistas.uv.mx/index.php/investigacionteatral/article/view/1053/1937>. Acesso em: 29 jun. 2015.

. Teatro y vanguardia en el México posrevolucionario (1920-1940). Azcapotzalco: Universidad Autónoma Metropolitana, 2005.

PACHECO HINOJOSA, María Marta. Panorama de la Iglesia Católica mexicana (1955 - 1973), Estudios, México DF: Instituto Tecnológico Autónomo de México, v. 3, n. 72, p. 66-99, 2005. Disponível em:< http://biblioteca.itam.mx/estudios/6089/72/MaMarthaPachecoPanoramadelaiglesia.pdf>. Acesso em: 20 dez. 2016.

PARTIDA TAYZAN, Armando. Se buscan dramaturgos I: entrevistas. México DF: CONACULTA / FONCA / INBA/ CITRU, 2002a.

Se buscan dramaturgos II: panorama crítico. México DF: Conaculta / FONCA / INBA / CITRU, 2002b.

Aspectos formales de la escritura dramática mexicana. Latin American Theater Review, Kansas: Universidade de Kansas, v. 31, n. 1, p.91-97, 1977. Disponível em: <https://journals.ku.edu/index.php/latr/article/view/1181>. Acesso em: 6 set. 2015.

Bertolt Brecht en la escena y dramaturgia mexicanas. Temas y variaciones, Azcapotzalco: Universidade Autônoma Metropolitana, n. 23, 2005, p. 123-163. Disponível em: < http://espartaco.azc.uam.mx/UAM/TyV/index.html>. Acesso em: 19 fev. 2016.

PASTOR, Beatriz. Discursos narrativos de la conquista: mitificación y emergencia. 2.ed. Hanover: Ediciones del Norte, 1988.

PAZ, Octavio. EI laberinto de la soledad. Postdata. Vuelta a EI laberinto de la soledad.

2.ed. México DF: Fondo de Cultura Económica, 1994. 
Introdução. In: LAFAYE, Jacques. Quetzalcóatl y Guadalupe: la formación de la conciencia nacional en México. 2.ed. Trad. Ida Vitale y Fulgencio López Vidarte. México DF: Fondo de Cultura Económica, 1992, p. 11-26. 1998.

. Sor Juana Inés de la Cruz o las trampas de la fe. 6. ed. Barcelona: Seix Barral,

PEIXOTO, Fernando. O que é teatro? 12.ed. São Paulo: Brasiliense, 1992.

PELLETIERI, Osvaldo. Teatro Latinoamericano: desde las vanguardias históricas hasta hoy. In: PIZARRO, Ana (Org.). América Latina: palavra, literatura e cultura. Campinas, SP: Unicamp, 1995. v. 3, p. 645-672.

PENSORE, Mehl. La historia en dos obras de Rodolfo Usigli, o el juego entre la fantasia y la realidad. Mester, Los Angeles: Universidade da California, v. 27, n. 1, p. 129-140, 1998. Disponível em: <http://escholarship.org/uc/item/42v4k7zb\#page-3>. Acesso em: 9 set. 2017.

PEREIRA, Armando. Generación de medio siglo: un momento de transición de la cultura mexicana. México DF: UNAM, 1997.

PERRONE-MOISÉS, Leyla. Vira e mexe nacionalismo: paradoxos do nacionalismo literário. São Paulo: Companhia das Letras, 2007.

PIZARRO, Ana. Prólogo. In: TROUCHE, André. América: história e ficção. Niterói: UFF, 2006, p.13-15.

PRESCOTT, William H. Historia de la Conquista de México. Tomo II. Madrid: Mercurio, s/d.

RAMOS, Luiz Fernando. O parto de Godot e outras encenações imaginárias: a rubrica como poética da cena. São Paulo: Hucitec / Fapesp, 1999.

A rubrica como literatura da teatralidade: modelos textuais \& poéticas da cena. Revista Sala Preta, São Paulo: Escola de Comunicação e Artes/USP, v. 1, n. 1, p. 9-22, 2001. Disponível em: < http://www.revistas.usp.br/salapreta/issue/view/4682/showToc>. Acesso em: 30 jan. 2017.

RAMOS, Samuel. El perfil del hombre y la cultura en México. 3.ed. Madrid: Espasa, 2001.

RASCÓN BANDA, Víctor Hugo. Nueva dramaturgia mexicana. Latin American Theatre Review, Kansas: Universidade do Kansas, v.18, n. 2, p. 89-92, 1985. Disponível em: < https://journals.ku.edu/index.php/latr/article/view/602>. Acesso em: 9 abr. 2015.

. La noche de Hernán Cortés. Proceso, 30 maio 1992. Disponível em: < https://www.proceso.com.mx/159456/la-noche-de-hernan-cortes>. Acesso em: 7 abr. 2018. 
La noche de Hernán Cortés II. Proceso, 6 jun. 1992. Disponível em: < https://www.proceso.com.mx/159499/la-noche-de-hernan-cortes-ii>. Acesso em: 7 abr. 2018

REYES, Mara (seudónimo de Marcela del Río). "Diorama teatral. Festival de Primavera" en Diorama de la Cultura, supl. Excélsior, n. 8 p. 4, jun. 1968. Disponível em: $<\mathrm{http}: / /$ www.resenahistoricateatromexico2021.net/proyecto_default.php?id=357\&op=1 \&texto_palabra=1968>. Acesso em: 12 out. 2017.

RICOEUR, Paul. Tempo e narrativa (Tomo I). Trad. Constança Marcondes Cesar. Campinas: Papirus, 1994.

Tempo e narrativa (Tomo II). Trad. Marina Appenzeller. Campinas: Papirus, 1995. 1997.

Tempo e narrativa (Tomo III). Trad. Roberto Leal Ferreira. Campinas: Papirus,

A memória, a história, o esquecimento. Trad. Alain François et. al. Campinas: Editora da Unicamp, 2007.

RODRÍGUEZ, Roberto R. La función de la imaginación en las Coronas de Rodolfo Usigli. Latin American Theater Review, Kansas: Universidade do Kansas, v. 2, n. 18, p. $\quad 37 \quad-\quad 44, \quad 1977 . \quad$ Disponível em: < https://journals.ku.edu/index.php/latr/article/view/280>. Acesso em: 9 abr. 2015.

ROGERS, V. Daniel. Cabronas, palabrotas y otras amenazas a la nación: La Diana Cazadora y Entre Villa y una mujer desnuda. In: BIXLER, Jacqueline E. (Comp.). Sediciosas seducciones: sexo, poder y palabras en el teatro de Sabina Berman. México DF: Escenología, 2004, p. 151-160.

ROSENFELD, Anatol. Teatro moderno. São Paulo: Perspectiva, 1977.

Prismas do teatro. São Paulo: Perspectiva, 2000.

ROTTERDAM, Erasmo de. Elogio da Loucura. Trad. Torrieri Guimarães. São Paulo: Rideel, 2003.

RUEDAS DE LA SERNA, Jorge. La novela corta de la Academia de Letrán. In: MIRANDA CÁRABES, Celia (Estudo preliminar, compilação, edição e notas). La novela corta en el primer romanticismo mexicano. 2.ed. México DF: Universidade Autônoma do México, 1998, p. 53-72.

SÁENZ CARRETE, Erasmo. José Fernando Ramírez: su último exilio europeo y la suerte de su última biblioteca. Signos históricos, n. 25, , p. 100-135, jan.-jun. 2011. Disponível em: $\quad<$ http://www.scielo.org.mx/scielo.php?script=sci_arttext\&pid=S166544202011000100004\&lng=es\&nrm=iso> . Acesso em: 14 jul. 2016.

SÁENZ FIERRO, Rosa María. (Coord.) Teatro del norte / teatro de frontera: antología de ensayos y ponencias. Chihuahua: Universidad Autónoma de Chihuahua, 2012. 
SAHAGÚN, Fray Bernardino de. EI México antiguo. Caracas: Biblioteca Ayacucho, s/d.

SALDÍVAR, Américo. Ideología y política del estado mexicano (1970-1976). México DF: Siglo Veintiuno, 1980.

SCARANO, Laura Rosana. Correspondencias estructurales y semánticas en $E l$ gesticulador y corona de sombra. Latin American Theatre Review, Kansas: Universidade do Kansas, v. 22, n. 1, p. 29-36, 1998. Disponível em: <https://journals.ku.edu/index.php/latr/article/view/752/727>. Acesso em: 9 abr. 2015.

SCHMELING, Manfred. Métathéâtre et intertexte: aspects du théâtre dans le théâtre. Paris: Lettres Modernes, 1982.

SCHNEIDER, Luis Mario. Fragua y gesta del teatro experimental en México: Teatro de Ulises, Escolares del Teatro, Teatro de Orientación. México DF: UNAM / Equilibrista, 1995.

SHAKESPEARE, William. Hamlet. São Paulo: Martin Claret, 2001.

SOLANA, Rafael. Teatro. [El juicio de Vicente Leñero, dirige Ignacio Retes] Siempre, 17 nov. 1971. Disponível em: <http://resenahistoricateatromexico2021.net/proyecto_default.php?id=6436\&op=1\&text o_palabra=Vicente\%20Lenero >. Acesso em: 25 fev. 2017.

SOMMER, Doris. Ficções de fundação: os romances nacionais da América Latina. Trad. Gláucia Renate Gonçalves e Eliana Lourença de Lima Reis. Belo Horizonte: UFMG, 2004.

STEINER, George. La muerte de la tragedia. Caracas: Monte Ávila, 1991.

SZONDI, Peter. Teoria do drama moderno (1880 - 1950). Trad. Luiz Sérgio Repa. São Paulo: Cosac \& Naify, 2001.

TAVIEL DE ANDRADE, Bárbara Fernández. Aproximación al teatro a través de las didascalias: Le mariage de Figaro. In: COLOQUIO CELEBRADO EN LA UNIVERSIDAD DE MURCIA, 5, 1996, Murcia. Aproximaciones diversas al texto literario. Murcia: Universidad de Murcia, 1996, p. 81-94. Disponível em: < https://dialnet.unirioja.es/servlet/libro?codigo=410123 >. Acesso em: 30 jan. 2017.

TAYLOR HANSEN, Lawrence Douglas. Los orígenes de la industria maquiladora en México. Trad. Jacqueline Fortson. Comercio exterior, México D.F.: Banco Nacional de Comercio Exterior, v. 53, n. 11, p. 1045-1056, nov. 2003. Disponível em: <revistas.bancomext.gob.mx/rce/magazines/59/7/RCE.pdf>. Acesso em: 10 jan. 2017.

TIMMOS, Wilbert H. Morelos: sacerdote, soldado, estadista. Trad. Carlos Valdés. 2.ed. México DF: Fondo de Cultura Económica, 1985. 
TOUCHARD, Pierre-Aimé. O teatro e a angústia dos homens. Trad. Pedro Paulo de Sena Madureira e Bruno Palma. São Paulo: Duas Cidades, 1970.

TORO, Alfonso de. Los caminos del teatro actual: hacia la plurimedialidad postmoderna o el fin del teatro aristotélico. Revista de l'Associació d'Investigació i Experimentació Teatral, Universidade de Barcelona, Barcelona, n. 47, p.17-31, 2005. Disponível em: <http://www.raco.cat/index.php/AssaigTeatre/article/view/146130>. Acesso em: 16. Jan. 2014.

TORRE VILLAR, Ernesto de la. La independencia de México. 2.ed. México DF: MAPFRE / Fondo de Cultura Económica, 1992.

TORRE VILLAR, Ernesto de la, GONZÁLEZ NAVARRO, Moises, ROSS, Stanley. Historia documental de México II. México DF: Universidad Nacional Autónoma de México / Instituto de Investigaciones Históricas, 1974.

TOSCANO, Salvador. Cuauhtémoc. Introd. Rafael Heliodoro Valle. México DF: Fondo de Cultura Económica, 1991.

TREJO DELABRE, Raúl. (coord.) Televisa, el quinto poder. 4.ed. México DF: Claves Latinoamericanas, 1989.

TROUCHE, André. América: história e ficção. Niterói: UFF, 2006.

UBERSFELD, Anne. Para ler o teatro I. Trad. José Simões. São Paulo: Perspectiva, 2005.

USIGLI, Rodolfo. Teatro completo. 3 vol. México DF: Fondo de Cultura Económica, 1979.

Teatro completo IV: escritos sobre la historia del teatro en México. Compilação, prólogo e notas Luis de Tavira. México DF: Fondo de Cultura Económica, 1996.

Corona de Luz: la virgen. México D.F.: Fondo de Cultura Económica, 1985.

VASCONCELOS, Ana Isabel P. Teixeira de. O drama histórico português do século XIX (1836-1856). Lisboa: Fundação Calouste Gulbenkian / Fundação para a ciência e tecnologia, 2005.

VASCONCELOS, José. The cosmic race: a bilingual edition. Tradução e notas Didier T. Jaén. Baltimore / Londres: John Hopkins University Press, 1997.

VÁSQUEZ MELÉNDEZ, Miguel Ángel. México personificado: un asomo al teatro del siglo XIX. México DF: INBA, 2012.

VERNANT, Jean-Pierre; VIDAL-NAQUET, Pierre. Mito e tragédia na Grécia antiga. São Paulo: Perspectiva, 2005.

VEYNE, Paul. Como se escreve a história. 3.ed. Trad. Alda Baltar e Maria Auxiliadora Kneipp. Brasília: UnB, 1995. 
VILLA, Marco Antonio. Francisco "pancho" Villa: uma liderança da vertente camponesa na revolução mexicana. São Paulo: Ícone, 1992.

VILLORO, Luis. Los grandes momentos del indigenismo mexicano. 3ed. México DF: El Colegio de México / El Colegio Nacional / Fondo de Cultura Económica, 1998.

VIZCAÍNO GUERRA, Fernando. El nacionalismo mexicano en los tiempos de la globalización y el multiculturalismo. México DF: UNAM, 2004.

VOLEK, Emil. La conquista de América en el teatro posmoderno. In: PELLETIERI, Osvaldo. (Ed.). El teatro y sus claves: estudios sobre teatro iberoamericano y argentino. Buenos Aires: Galerna / UBA, 1996, p. 257-272.

WARMAN, Arturo. Los indios mexicanos en el umbral del milenio. México: FCE, 2003.

WATT, Ian. A ascensão do romance: estudos sobre Defoe, Richardson e Fielding. Trad. Hildegard Fiest. São Paulo: Companhia das Letras, 2007.

WHITE, Hayden. Meta-história: a imaginação histórica do século XIX. Trad. José Laurênio de Melo. 2.ed. São Paulo: Edusp, 2008.

O texto histórico como artefato literário. In: Trópicos do discurso: ensaios sore a crítica da cultura. Trad. Alípio Correia de Franca Neto, Antônio de Pádua Danesi. São Paulo: Edusp, 2001, p. 97-116.

O fardo da história. In: Trópicos do discurso: ensaios sore a crítica da cultura. 2.ed. Trad. Alípio Correia de Franca Neto, Antônio de Pádua Danesi. São Paulo: Edusp, 2001, p. 39-63

WILLIAMS, Raymond. Tragédia moderna. São Paulo: Cosac \& Naify, 2002.

YAÑEZ, María-Paz. La historia: inagotable temática novelesca (esbozo de un estudio sobre la novela histórica española hasta 1834 y análisis de la aportación de Larra al género). Bern: Peter Lang, 1991.

ZERMEÑO PADILLA, Guillermo. Notas para observar la evolución de la historiografía en México en el siglo XX. Espacio, tiempo y forma, vol. 10, 1997, p. 441-456. Disponível em: <http://www.pucsp.br/cehal/downloads/relatorios/revista_espacio_tiempo_forma/1997_ 10_historiografia.pdf>. Acesso em: 10 jul. 2015. 